FACULDADE DE ZOOTECNIA E ENGENHARIA DE ALIMENTOS

\author{
MARÍLIA MORAES LOVISON
}

Óleo essencial de orégano nanoemulsionado: produção, caracterização físico-química, atividade antimicrobiana e antioxidante in vitro e aplicação em patê de frango 


\section{Óleo essencial de orégano nanoemulsionado: produção, caracterização físico-química, atividade antimicrobiana e antioxidante in vitro e aplicação em patê de frango}

Versão Corrigida

Tese apresentada à Faculdade de Zootecnia e Engenharia de Alimentos da Universidade de São Paulo, como parte dos requisitos para a obtenção do Título de Doutora em Ciências do Programa de Pós-Graduação em Engenharia de Alimentos

Área de concentração: Ciências da Engenharia de Alimentos

Orientadora: Prof ${ }^{a} \operatorname{Dr}^{a}$ Samantha Cristina de Pinho

Co-orientadora: $\operatorname{Prof}^{\mathrm{a}} \mathrm{Dr}^{\mathrm{a}}$ Andrezza Maria Fernandes 
Ficha catalográfica elaborada pelo

Serviço de Biblioteca e Informação, FZEA/USP, com os dados fornecidos pelo(a) autor(a)

MM336ó Moraes-Lovison, Marília

óleo essencial de orégano nanoemulsionado:

produção, caracterização físico-química, atividade antimicrobiana e antioxidante in vitro e aplicação em... / Marília Moraes-Lovison ; orientador Samantha Cristina de Pinho; coorientador Andrezza Maria Fernandes . -- Pirassununga, 2017.

$128 \mathrm{f}$.

Tese (Doutorado - Programa de Pós-Graduação em Engenharia de Alimentos) -- Faculdade de Zootecnia e Engenharia de Alimentos, Universidade de São Paulo.

1. Óleo essencial de orégano. 2. Nanoemulsões. 3. Atividade antimicrobiana. 4. Antioxidante. 5. Patê de frango. I. Pinho, Samantha Cristina de, orient. II. Fernandes, Andrezza Maria, coorient. III. Título. 
Óleo essencial de orégano nanoemulsionado: produção, caracterização físico-química, atividade antimicrobiana e antioxidante in vitro e aplicação em patê de frango

Tese apresentada à Faculdade de Zootecnia e Engenharia de Alimentos da Universidade de São Paulo, como parte dos requisitos para a obtenção do Título de Doutora em Ciências do Programa de Pós-Graduação em Engenharia de Alimentos Área de concentração: Ciências da Engenharia de Alimentos

Orientadora: Prof ${ }^{\mathrm{a}} \mathrm{Dr}^{\mathrm{a}}$ Samantha C. de Pinho Co-orientadora: Prof ${ }^{\mathrm{a}} \mathrm{Dr}^{\mathrm{a}}$ Andrezza M. Fernandes

Data de aprovação: 08 de junho de 2017.

Banca Examinadora:

Profa. Dra. Samantha Cristina de Pinho (Orientadora) Faculdade de Zootecnia e Engenharia de Alimentos (FZEA/USP)

Profa. Dra. Ana Silvia Prata Soares

Faculdade de Engenharia de Alimentos (FEA/UNICAMP)

Prof. Dr. Rodney Alexandre Ferreira Rodrigues

Centro Pluridisciplinar de Pesquisas Químicas, Biológicas e Agrícolas (CPQBA/UNICAMP)

Prof. Dr. Marco Antonio Trindade

Faculdade de Zootecnia e Engenharia de Alimentos (FZEA/USP)

Profa. Dra. Ana Maria Centola Vidal

Instituição: Faculdade de Zootecnia e Engenharia de Alimentos (FZEA/USP) 
Dedicatória

Dedico esta tese aos meus queridos pais, Dulcineia e Nivaldo, por todo esforço e dedicação para que eu pudesse realizar este trabalho. A melhor parte de mim são vocês. 


\section{AGRADECIMENTOS}

A Deus por ter colocado pessoas tão maravilhosas em minha vida, as quais me ajudam a trilhar o meu caminho com muita força e perseverança.

Aos meus pais, que são os maiores exemplos da minha vida e que me ensinaram o quão importante é amar e ser amado. Obrigada por todo amor e cuidado que vocês tiveram por mim e pelo meu filho, porque sem vocês eu nunca teria conseguido realizar este trabalho. Meu eterno amor e gratidão por vocês.

À professora e amiga Samantha Cristina de Pinho por toda dedicação e aprendizagem concebidas durante todos esses anos de orientação. No momento em que mais precisei de compreensão você esteve ao meu lado, e este apoio foi fundamental para que eu conseguisse seguir em frente. Obrigada por exercer sua profissão com tanto amor e dedicação.

Ao meu filho Augusto Moraes Lovison, que me fez sentir o verdadeiro significado do amor incondicional e me deu forças para continuar quando sentia vontade de desistir pelo cansaço.Você me faz querer ser uma pessoa melhor a cada dia. Te amo.

Ao meu marido, André Lovison, por toda sua paciência e apoio ao longo desses últimos 12 anos. Obrigada pelo amor dedicado à nossa família.

À minha irmã Mirela Moraes que sempre esteve ao meu lado em todos os momentos da minha vida, me apoiando, cuidando de mim e me mostrando que devemos lidar com os problemas da vida sempre com um sorriso no rosto. Obrigada por toda dedicação comigo e com meu filho.

Às pessoas que contribuíram para o desenvolvimento deste trabalho: Luís Fernando Marostegan, Marina Peres, Isabela Fukuda, Emerson Henrique dos Santos, Marluci Ghiraldi, Fabiana Kojima e Maria Souza. Muito obrigada pela dedicação a este trabalho.

Aos amigos de laboratório, principalmente, Cynthia de Carli, Ivana Andrade, Nayla Souki, Juliana Silveira e Marluci Ghiraldi. Obrigada pela amizade, pelo apoio e pelas conversas diárias no almoço. Vocês são muito especiais em minha vida. 
Aos funcionários do departamento de Engenharia de Alimentos, Guilherme Silva, Marcelo Thomazini, Carla Monaco Lourenço, Camila Velludo Molina e Fábio Gallo. Obrigada pelo apoio na realização de análises e pelos conhecimentos ensinados.

Ao pesquisador Dr. Rodney A.F. Rodrigues pelo apoio nas análises de cromatografia gasosa realizadas no CPQBA/UNICAMP.

À $\operatorname{prof}^{\mathrm{a}} \operatorname{Dr}^{\mathrm{a}}$ Andrezza Maria Fernandes, pela co-orientação deste projeto na área de microbiologia.

Ao Prof. Dr. Rodrigo Petrus por disponibilizar a planta piloto para a produção do patê de frango.

À FAPESP, pelo apoio financeiro nos projetos e bolsas 2012/01460-2, 2011/14443-6, 2011/20916-4 e 2013/25182-4.

À Faculdade de Zootecnia e Engenharia de Alimentos (FZEA/USP), por toda apoio e ensinamentos recebidos. 
"A experiência é o nome que damos aos nossos erros"

Oscar Wilde

"Quem caminha sozinho pode até chegar mais rápido, mas aquele que vai acompanhado, com certeza vai mais longe."

Clarice Lispector 


\section{RESUMO}

MORAES-LOVISON, M. Óleo essencial de orégano nanoemulsionado: produção, caracterização físico-química, atividade antimicrobiana e antioxidante in vitro e aplicação em patê de frango. 2017. 130 f. Tese (Doutorado) - Faculdade de Zootecnia e Engenharia de Alimentos, Universidade de São Paulo, Pirassununga, 2017.

O óleo essencial de orégano (OEO), devido à presença de compostos fenólicos na sua composição, como o carvacrol e timol, pode ser considerado um potencial agente antioxidante e antimicrobiano. Nos últimos anos há um crescente interesse na utilização desse óleo com a finalidade de reduzir ou substituir antioxidantes e conservantes sintéticos, os quais são amplamente utilizados na indústria de alimentos. Entretanto, o emprego direto de óleos essenciais em alimentos enfrenta alguns desafios tecnológicos, como sua baixa estabilidade durante a armazenagem e a dificuldade de incorporação devido ao seu caráter hidrofóbico. Portanto, a encapsulação do OEO em sistemas nanoemulsionados é uma alternativa para contornar tais problemas. Esta Tese teve como principal objetivo a produção e a caracterização de nanoemulsões encapsulando OEO para avaliar a atividade antioxidante e ação antibacteriana, para Staphylococcus aureus e Escherichia coli, in vitro e em patê de frango, sendo que este produto cárneo é considerado um alimento favorável para a multiplicação de micro-organismos e também é suscetível a oxidação lipídica e proteica durante o armazenamento. Foram produzidas nanoemulsões contendo $3,25 \%(\mathrm{NA}-3,25)$ e $5 \%$ (NA-5) de OEO, as quais foram obtidas pelo método de temperatura de inversão de fases, com diâmetros reduzidos de gota $(25,5 \pm 0,21$ e 42,4 $\pm 1,7 \mathrm{~nm})$. Ambas as nanoemulsões apresentaram-se estáveis em relação ao seu tamanho médio durante 90 dias de armazenamento, o que viabilizou avaliar a atividade antimicrobiana e antioxidante das nanoemulsões in vitro e no patê de frango. O patê de frango produzido foi submetido a 5 tratamentos, com a finalidade de avaliar a estabilidade físicoquímica durante o armazenamento: T 1-sem antioxidantes e conservantes, T 2- 0,06 \% (m/m) OEO não-emulsionado, T3- $6 \%(\mathrm{~m} / \mathrm{m})$ das nanoemulsões NA-3,25, T4- 1,2 \% $(\mathrm{m} / \mathrm{m})$ das nanoemulsões NA-5 e T5- BHT e nitrito de sódio. Os parâmetros de cor determinados durante o armazenamento mostram que em todos os tratamentos ocorreu descoloração. Entretanto, essa alteração de cor não foi observada pelos provadores durante a análise sensorial. Também foi possível observar durante o armazenamento do patê de frango que todos os tratamentos 
sofreram oxidação proteica, e portanto, o OEO livre e nanoemulsionado, bem como o antioxidante sintético BHT, não foram eficientes em inibir a oxidação das proteínas. As análises de oxidação lipídica mostraram que as nanoemulsões apresentaram maior ação antioxidante do que o OEO livre e o antioxidante sintético BHT e a análise sensorial do patê de frango indicou que o OEO nanoemulsionado e livre, nas concentrações empregadas neste estudo, $0,06 \%$ e 0,2 $\%(\mathrm{~m} / \mathrm{m})$, afetaram as propriedades sensoriais de odor e sabor do produto cárneo em estudo. Portanto, a ação antibacteriana e antioxidante das nanoemulsões indicou que o $\mathrm{OEO}$ nanoemulsionado pode ser um potencial substituto aos conservantes e antioxidantes sintético utilizados na indústria de produtos cárneos.

Palavras-chave: nanoemulsões. temperatura de inversão de fases. potencial antibacteriano. Staphylococcus aureus. Escherichia coli. produto cárneo. 


\begin{abstract}
MORAES-LOVISON, M. Oregano essential oil nanoemulsion: production, physicalchemical characterization, antimicrobial and antioxidant activity in vitro and application in chicken pâté. 2017. 130 f. Thesis (Ph.D.) - School of Animal Science and Food Engineering, University of São Paulo (USP) Pirassununga, 2017.
\end{abstract}

Oregano essential oil (OEO) can be considered a potential antioxidant and antimicrobial agent due to the presence of phenolic compounds, such as carvacrol and thymol. In recent years, there has been growing interest in using this oil to reduce or replace artificial antioxidants and synthetic preservatives, which are widely used in the food industry. However, the direct incorporation of essential oils in food faces some technological challenges, such as low storage stability (due to high volatility of some compounds) and the difficulty of incorporation, as they are hydrophobic. Therefore, the encapsulation of OEO in nanodispersions can be an alternative to overcome these drawbacks. The main objective of this Thesis was the production and characterization of nanoemulsions encapsulating OEO to evaluate their antioxidant activity and antibacterial action, for Staphylococcus aureus and Escherichia coli, in vitro and in chicken pate, being that this meat product is considered a favorable food for the multiplication of microorganisms and is also susceptible to lipid and protein oxidation during storage.The nanoemulsions were produced with 3,25\% (NA-3.25) and 5\% (NA-5) OEO (m/m), obtained by the phase inversion temperature method and presented reduced droplet sizes $(25.5 \pm 0.12$ and $42.4 \pm 1.7 \mathrm{~nm}$ ). Both nanoemulsions presented kinetic stability during 90 days of storage, which made it possible to evaluate the antimicrobial and antioxidant activity of nanoemulsions in vitro and in chicken pâté. The chicken pâté was submitted to 5 treatments, with the purpose of evaluating the physical-chemical stability of each treatment during storage: T1- without antioxidants and preservatives, T 2- $0.06 \%(\mathrm{w} / \mathrm{w})$ free OEO, T3 - $6 \%(\mathrm{w} / \mathrm{w})$ NA-3.5, T41.2\% (w / w) NA-5 and T5: BHT and sodium nitrite. Color parameters determined during storage show that all treatments were discolored, however, this color change was not observed by the panelists during the sensory analysis. The lipid oxidation reactions showed that the nanoemulsions presented higher antioxidant action than free OEO and synthetic antioxidant, BHT and the sensorial analysis of the chicken pâté indicated that the nanoemulsions and the free OEO, in the concentrations used in this study, $0.06 \%$ and $0.2 \%(\mathrm{w} / \mathrm{w})$, affected the odor and flavor properties of the meat product. Therefore, the antibacterial and antioxidant action of 
nanoemulsions indicated that nanoemulsified OEO may be a potential substitute for the preservatives and antioxidants synthetic used in the meat products industry.

Keywords: nanoemulsions. phase inversion temperature. antibacterial potential. Staphylococcus aureus. Escherichia coli. meat product. 


\section{LISTA DE FIGURAS}

Figura 1. Estrutura química dos principais compostos que constituem o óleo essencial de orégano: carvacrol, timol e $\gamma$-terpineno.

Figura 2. Esquema das diferentes rotas promovidas pelas nanoemulsões para a interação de óleo essencial com as membranas celulares microbianas: (1) Transporte passivo através da membrana celular, (2) Fusão com a bicamada de fosfolipídio celular, (3) Partição na fase aquosa, e (4) Interação eletrostática com a membrana celular.

Figura 3. Diagrama esquemático da estrutura das nanoemulsões $\mathrm{O} / \mathrm{A}$ formada a partir de óleo, água e tensoativo.

Figura 4. Diagrama esquemático da energia livre da formação de nanoemulsões $(\Delta \mathrm{G})$ : as nanoemulsões têm uma energia livre maior do que as fases separadas de água e óleo............ 12

Figura 5. Mecanismos físicos-químicos de desestabilização das nanoemulsões: separação gravitacional (sedimentação ou cremeação), floculação, coalescência ou maturação de Ostwald.

Figura 6. Diagrama do comportamento formulação-composição por inversão de fases transicional e catastrófica.

Figura 7. Diferentes tipos de sistemas coloidais que são formados de acordo com a geometria molecular dos tensoativos.

Figura 8. Diagrama esquemático da dependência da temperatura com a curvatura espontânea das monocamadas de tensoativo e sua influência nas propriedades de uma emulsão.

Figura 9. Mecanismo de geração das nanoemulsões pelo método PIT: (a) a temperatura está abaixo da temperatura de inversão de fases (emulsãoO/A); (b) ocorre o aumento da temperatura e os tensoativos se tornam gradualmente lipofílico (são solubilizados pela fase oleosa); (c) sistema está na temperatura de inversão de fases: microemulsões bicontínuas; e (d) resfriamento rápido do sistema tensoativo-óleo-água, onde ocorre a migração espontânea e rápida do óleo para a fase aquosa: formação das nanoemulsões.

Figura 10. Mudanças na condutividade e na turbidez em função da temperatura, em uma inversão transicional.

Figura 11. Reação entre malonaldeído (MA) e ácido 2- tiobarbitúrico que ocorre durante a análise de TBARS originando um composto de coloração rosa.

Figura 12. Fluxograma das etapas experimentais realizadas durante a Tese.

Figura 13. Estrutura química dos tensoativos utilizados na formulação das nanoemulsões encapsulando óleo essencial de orégano. 
Figura 14. Fluxograma da produção do patê de frango e os tratamentos aplicados. *Quantidade determinada pela concentração inibitória mínima dos testes in vitro: $0,2 \%(\mathrm{~m} / \mathrm{m})$ para as nanoemulsões NA-3,25 e 0,06 \% (m/m) para as nanoemulsões NA-5. ${ }^{* *}$ Valores máximos de adição de BHT (100 mg/kg) e nitrito de sódio (150 mg/kg) permitidos pela legislação brasileira (BRASIL, 2007).

Figura 15. Condutividade elétrica em função da temperatura das nanoemulsões, produzidas pelo método PIT, para determinação da temperatura de inversão de fases: $(\bullet)$ nanoemulsões NA-3,25 e (घ) nanoemulsões NA-5.

Figura 16. Curvas de distribuição de tamanho de gotas para as nanoemulsões NA 3,25 e NA5 durante o início e o final do armazenament sob refrigeração: $(\rightarrow)$ dia 1 e $(\rightarrow)$ dia $90 \ldots . . . .59$

Figura 17. Aspecto visual das nanoemulsões NA-3,25 (A) e NA-5 (B), produzidas pelo método PIT, no dia 1 e após 90 dias de armazenamento.

Figura 18.Valor de $\mathrm{r} 3(\mathrm{~nm} 3)$ das nanoemulsões vs tempo, durante o armazenamento sob refrigeração: $(\bullet)$ nanoemulsões NA-3,25 e (•) nanoemulsões NA-5.

Figura 19. Cromatograma do óleo essencial de orégano puro.

Figura 20. Quantificação dos compostos voláteis presentes no óleo essencial de orégano nanoemulsionado durante o período de 60 dias de armazenamento sob refrigeração das nanoemulsões NA-3,25: $(\bullet)$ carvacrol, $(\boldsymbol{\bullet}) \gamma$-terpineno e $(\boldsymbol{\Delta})$ timol.

Figura 21. Quantificação dos compostos voláteis presentes no OEO nanoelsionado durante o período de 60 dias de armazenamento sob refrigeração das nanoemulsões NA-5: (•) carvacrol, (घ) $\gamma$-terpineno e $(\boldsymbol{\Delta})$ timol.

Figura 22. Curvas de multiplicação para $S$. aureus e E. coli: (ロ) controle negativo (sem agente antibacteriano); ( $\mathbf{\Delta}$ ) nanoemulsão NA-3,25 na concentração inibitória mínima; e ( $)$ controle positivo (antibiótico cloranfenicol: $1 \mathrm{mg} / \mathrm{ml}$ ).

Figura 23. Curva de multiplicação para $S$. aureus e E. coli: (ロ) controle negativo (sem agente antibacteriano); ( $\mathbf{\Delta})$ nanoemulsão NA-5 na concentração inibitória mínima; e (४) controle positivo (antibiótico cloranfenicol: $1 \mathrm{mg} / \mathrm{ml}$ ).

Figura 24. Concentração de óleo essencial de orégano $(\mathrm{mg} / \mathrm{mL})$ vs. \% redução dos radicais $\mathrm{DPPH}^{\circ}$

Figura 25. Porcentagem de redução dos radicais $\mathrm{DPPH}^{\bullet}$ durante o período de 24 semanas de armazenamento das nanoemulsões sob refrigeração: $(\bullet)$ nanoemulsões NA-3,25 (com 3,25\% de OEO) e (ロ) nanoemulsões NA-5 (com $5 \%$ de OEO). 
Figura 26. Quantificação do teor de fenólicos totais durante o período de 24 semanas de armazenamento das nanoemulsões sob refrigeração: (•) nanoemulsões NA-3,25 (com 3,25\% de OEO) e (匹) nanoemulsões NA-5 (com $5 \%$ de OEO).

Figura 27. Presença de colônias de levedura, pela análise microbiológica de contagem de micro-organismos viáveis totais, no dia 90 de armazenamento das amostras de patê de frango. Da esquerda para direita: T4 (com adição de nanoemulsões NA-5) e T5 (adição de BHT e nitrito de sódio).

Figura 28. Curvas de inibição da multiplicação de $S$. aureus durante o período de 8 dias, após a contaminação experimental das amostras. ( $\bullet$ T1: sem antioxidantes e conservantes, (•) T2: adição de $0,06 \%(\mathrm{~m} / \mathrm{m})$ de óleo essencial de orégano não-emulsionado, $(\boldsymbol{\Delta})$ T3: adição de $6 \%$ $(\mathrm{m} / \mathrm{m})$ das nanoemulsões NA-3,25, (×) T4: adição de 1,2 \% (m/m) das nanoemulsões NA-5 e (०) T5: adição de BHT e nitrito de sódio.

Figura 29. Curvas de inibição da multiplicação de $E$. coli, durante o período de 8 dias, após a contaminação experimental das amostras. ( $\bullet$ T1: sem antioxidantes e conservantes, (ロ) T2: adição de $0,06 \%(\mathrm{~m} / \mathrm{m})$ de óleo essencial de orégano não-emulsionado, $(\boldsymbol{\Delta})$ T3: adição de $6 \%$ $(\mathrm{m} / \mathrm{m})$ das nanoemulsões NA-3,25, $(\times)$ T4: adição de 1,2 \% $(\mathrm{m} / \mathrm{m})$ das nanoemulsões NA-5 e (०) T5: adição de BHT e nitrito de sódio.

Figura 30. Resultados de $\mathrm{pH}$ das amostras de patê de frango durante o período de 16 semanas de armazenamento sob refrigeração. Tratamentos: ( $\downarrow)$ T1: sem antioxidantes e conservantes, (ロ) T2: adição de $0,06 \%(\mathrm{~m} / \mathrm{m})$ de óleo essencial de orégano não-emulsionado, ( $\boldsymbol{\Delta})$ T3: adição de $6 \%(\mathrm{~m} / \mathrm{m})$ das nanoemulsões NA-3,25, (×) T4: adição de 1,2\% $(\mathrm{m} / \mathrm{m})$ das nanoemulsões NA-5 e (०) T5: adição de BHT e nitrito de sódio.

Figura 31. Valores médios de carbonilas das amostras de patê de frango durante 16 semanas de armazenamento sob refrigeração. Tratamentos: ( $\downarrow)$ T1: sem antioxidantes e conservantes, (घ) T2: adição de $0,06 \%(\mathrm{~m} / \mathrm{m})$ de óleo essencial de orégano não-emulsionado, ( $\boldsymbol{\Delta})$ T3: adição de $6 \%(\mathrm{~m} / \mathrm{m})$ das nanoemulsões NA-3,25, (×) T4: adição de 1,2\% (m/m) das nanoemulsões NA-5 e (०) T5: adição de BHT e nitrito de sódio.

Figura 32. Valores médios de índice de peróxido das amostras de patê de frango durante 16 semanas de armazenamento sob refrigeração. Tratamentos: ( ) T1: sem antioxidantes e conservantes, (匹) T2: adição de $0,06 \%(\mathrm{~m} / \mathrm{m})$ de óleo essencial de orégano não-emulsionado, (A) T3: adição de $6 \%(\mathrm{~m} / \mathrm{m})$ das nanoemulsões NA-3,25, (×) T4: adição de 1,2\% $\%(\mathrm{~m} / \mathrm{m})$ das nanoemulsões NA-5 e (०) T5: adição de BHT e nitrito de sódio. 86

Figura 33. Distribuição do grau de instrução do chefe da família dos provadores que participaram da análise sensorial do patê de frango: (a) de analfabeto a fundamental 1 (primário) incompleto; (匹) de fundamental 1 (primário) completo a fundamental 2 (ginásio) incompleto; (ロ) de fundamental 2 (ginásio) completo e médio (colegial) incompleto; (ロ) de médio (colegial) completo a superior incompleto; (a) superior completo. 89 
Figura 34. Distribuição da renda familiar dos provadores que participaram da análise sensorial

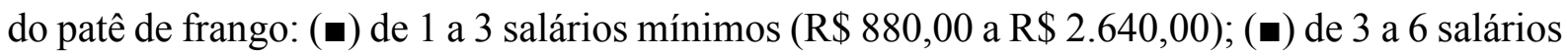
mínimos (R\$ 2.640,00 a R\$ 5.280,00); (匹) de 6 a 10 salários mínimos (R \$ 5.280,00 a R\$ 8.800,00); (ロ) mais de 10 salários mínimos (acima de $\mathrm{R} \$ 8.800,00)$.

Figura 35. Distribuição da frequência de consumo de patê dos provadores que participaram da análise sensorial: (匹) sempre (uma vez por semana ou mais); (ロ) frequentemente (de 2 a 3 vezes por mês); (घ) moderadamente (1 vez por mês); (घ) algumas vezes (menos que 1 vez por mês); (ם) raramente (somente em ocasiões especiais).

Figura 36. Porcentagens de provadores correspondente aos atributos de cor utilizando a escala de diferença do controle: $0=$ nenhuma diferença do controle, $1=$ ligeiramente diferente do controle, $2=$ pouco diferente do controle, $3=$ muito diferente do controle, $4=$ muitíssimo diferente do controle, $5=$ extremamente diferente do controle. (घ) T1: sem antioxidantes e conservantes, (匹) T2: adição de $0,06 \%(\mathrm{~m} / \mathrm{m})$ de óleo essencial de orégano não-emulsionado, (ロ) T3: adição de $6 \%(\mathrm{~m} / \mathrm{m})$ das nanoemulsões NA-3,25 e (ロ) T4: adição de 1,2 \% (m/m) das nanoemulsões NA-5.

Figura 37. Aspecto visual dos patês de frango nos dias 1 e 90 de armazenamento. Da esquerda para direita: T 1: sem antioxidantes e conservantes, T 2: adição de 0,06 \% (m/m) de óleo essencial de orégano não-emulsionado, T3: adição de $6 \%(\mathrm{~m} / \mathrm{m})$ das nanoemulsões NA-3,25, T4: adição de 1,2 \% (m/m) das nanoemulsões NA-5 e T5: adição de BHT e nitrito de sódio. 96

Figura 38. Distribuição da intenção de compra dos provadores em relação as amostras de patê de frango: (घ) certamente não compraria o produto; ( $)$ possivelmente não compraria o produto; (匹) talvez compraria / talvez não compraria; (ロ) possivelmente compraria o produto; (घ) certamente compraria o produto. Tratamentos: T1: sem antioxidantes e conservantes, T2: adição de $0,06 \%(\mathrm{~m} / \mathrm{m})$ de óleo essencial de orégano não-emulsionado, T3: adição de $6 \%$ $(\mathrm{m} / \mathrm{m})$ das nanoemulsões NA-3,25, T4: adição de $1,2 \%(\mathrm{~m} / \mathrm{m})$ das nanoemulsões NA-5 e T5: adição de BHT e nitrito de sódio. 100 


\section{LISTA DE TABELAS}

Tabela 1. Classificação dos sistemas coloidais baseada no tamanho de diâmetro das gotas e na estabilidade termodinâmica.

Tabela 2. Estudos recentes sobre a aplicação de nanoemulsões em diversos tipos de alimentos.

Tabela 3. Descrição das formulações $(\% \mathrm{~m} / \mathrm{m})$ das nanoemulsões encapsulando óleo essencial de orégano produzidas pelo método de temperatura de inversão de fases.

Tabela 4. Valores médios do diâmetro hidrodinâmico (DH), índice de polidispersidade (PDI) e turbidez das nanoemulsões NA-3,25 durante o período de 90 dias das amostras armazenadas sob refrigeração.

Tabela 5. Valores médios do diâmetro hidrodinâmico (DH), índice de polidispersidade (PDI) e turbidez das nanoemulsões NA-5 durante o período de 90 dias das amostras armazenadas sob refrigeração.

Tabela 6. Concentração inibitória mínima (CIM) e concentração bactericida mínima (CBM) (mg de óleo essencial de orégano/mL), das nanoemulsões NA-3,25, para Staphylococcus aureus e Escherichia coli, durante o período de 90 dias de armazenamento.

Tabela 7. Concentração inibitória mínima (CIM) e concentração bactericida mínima (CBM) (mg de óleo essencial de orégano/mL), das nanoemulsões NA-5, para Staphylococcus aureus e Escherichia coli, durante o período de 90 dias de armazenamento.....

Tabela 8. Composição centesimal do patê de frango. Tratamentos: $\mathrm{T} 1$ : sem antioxidantes e conservantes, T2: adição de $0,06 \%(\mathrm{~m} / \mathrm{m})$ de óleo essencial de orégano não-emulsionado, T3: adição de $6 \%(\mathrm{~m} / \mathrm{m})$ das nanoemulsões NA-3,25, T4: adição de $1,2 \%(\mathrm{~m} / \mathrm{m})$ das nanoemulsões NA-5 e T5: adição de BHT e nitrito de sódio.

Tabela 9. Valores de $\mathrm{L}^{*}, \mathrm{a}^{*}, \mathrm{~b}^{*}$, Croma $\left(\mathrm{C}^{*}\right)$, ângulo Hue $\left(\mathrm{H}^{*}\right)$ e diferença total de cor $(\Delta \mathrm{E})$ durante o armazenamento (16 semanas).

Tabela 10. Valores médios de substâncias reativas ao ácido tiobarbitúrico (TBARS) durantes 16 semanas de armazenamento. Tratamentos: T1: sem antioxidantes e conservantes, T2: adição de $0,06 \%(\mathrm{~m} / \mathrm{m})$ OEO livre, T3: adição de $6 \%(\mathrm{~m} / \mathrm{m})$ das nanoemulsões NA-3,25, T4: adição de $1,2 \%(\mathrm{~m} / \mathrm{m})$ das nanoemulsões NA-5 e T5: adição de BHT e nitrito de sódio. 88

Tabela 11. Valores médios das notas atribuídas para os atributos de sabor e odor utilizando a escala de diferença do controle: $0=$ nenhuma diferença do controle, $1=$ ligeiramente diferente do controle, $2=$ pouco diferente do controle, $3=$ muito diferente do controle, $4=$ muitíssimo diferente do controle, $5=$ extremamente diferente do controle. Tratamentos: T2: adição de 0,06 
$\%(\mathrm{~m} / \mathrm{m})$ de óleo essencial de orégano não-emulsionado, T3: adição de $6 \%(\mathrm{~m} / \mathrm{m})$ das nanoemulsões NA-3,25, T4: adição de $1,2 \%(\mathrm{~m} / \mathrm{m})$ das nanoemulsões NA-5 e T5: adição de BHT e nitrito de sódio.

Tabela 12. Valores médios das notas atribuídas para odor na análise sensorial, utilizando a escala hedônica estruturada de 9 pontos, durante o período de armazenagem de 90 dias. Tratamentos: T1: sem antioxidantes e conservantes, T2: adição de $0,06 \%(\mathrm{~m} / \mathrm{m})$ de óleo essencial de orégano não-emulsionado, T3: adição de $6 \%(\mathrm{~m} / \mathrm{m})$ das nanoemulsões NA-3,25, T4: adição de 1,2\% (m/m) das nanoemulsões NA-5 e T5: adição de BHT e nitrito de sódio. 94

Tabela 13. Valores médios das notas atribuídas para cor na análise sensorial, utilizando a escala hedônica estruturada de 9 pontos, durante o período de armazenagem de 90 dias. Tratamentos: T1: sem antioxidantes e conservantes, T2: adição de $0,06 \%(\mathrm{~m} / \mathrm{m})$ de óleo essencial de orégano não-emulsionado, T3: adição de $6 \%(\mathrm{~m} / \mathrm{m})$ das nanoemulsões NA-3,25, T4: adição de 1,2 \% $(\mathrm{m} / \mathrm{m})$ das nanoemulsões NA-5 e T5: adição de BHT e nitrito de sódio

Tabela 14. Valores médios das notas atribuídas para qualidade global na análise sensorial, utilizando a escala hedônica estruturada de 9 pontos, durante o período de armazenagem de 90 dias. Tratamentos: T1: sem antioxidantes e conservantes, T2: adição de $0,06 \%(\mathrm{~m} / \mathrm{m})$ de óleo essencial de orégano não-emulsionado, T3: adição de $6 \%(\mathrm{~m} / \mathrm{m})$ das nanoemulsões NA-3,25, T4: adição de 1,2\% (m/m) das nanoemulsões NA-5 e T5: adição de BHT e nitrito de sódio. 95

Tabela 15. Valores médios dos atributos de odor, cor e sabor obtidos pelo teste de aceitação, utilizando a escala hedônica estruturada de 9 pontos $(1=$ desgostei muitíssimo, $2=$ desgostei muito, $3=$ desgostei regularmente, $4=$ desgostei ligeiramente, $5=$ indiferente, $6=$ gostei ligeiramente, $7=$ gostei regularmente, $8=$ gostei muito e $9=$ gostei muitíssimo). Tratamentos: $\mathrm{T} 1$ : sem antioxidantes e conservantes, T2: adição de $0,06 \%(\mathrm{~m} / \mathrm{m})$ de óleo essencial de orégano não-emulsionado, T3: adição de $6 \%(\mathrm{~m} / \mathrm{m})$ das nanoemulsões NA-3,25, T4: adição de 1,2 \% $(\mathrm{m} / \mathrm{m})$ das nanoemulsões NA-5 e T5: adição de BHT e nitrito de sódio 98 


\section{LISTA DE ABREVIATURAS E SIGLAS}

A/O - água/óleo

BHT - hidroxitolueno butilado

CBM - Concentração Bactericida Mínima

CIM - Concentração Inibitória Mínima

E. coli-Escherichia coli

EIP - emulsion inversion point (ponto de inversão de emulsão)

HLD -desvio hidrofílico-lipofílico

IC50 - concentração referente à redução de $50 \%$ dos radicais de DPPH

NA 3,25 - nanoemulsões contendo 3,25\% $(\mathrm{m} / \mathrm{m})$ de óleo essencial de orégano

NA 5 - nanoemulsões contendo $5 \%(\mathrm{~m} / \mathrm{m})$ de óleo essencial de orégano

O/A - óleo/água

$\mathbf{O E}$ - óleo essencial

OEO - óleo essencial de orégano

PIC - phase inversion composition (composição de inversão de fases)

PIT - phase inversion temperature (temperatura de inversão de fase)

S. aureus - Staphylococcus aureus

SOR - razão tensoativo/óleo

TBARS - substâncias reativas ao ácido tiobarbitúrico

WOR - razão água/óleo

DPPH - 2,2-difenil-1-picrilhidrazila 


\section{LISTA DE SÍMBOLOS}

$\tau$ - turbidez

p - parâmetro de empacotamento do tensoativo

$\Delta \mathbf{G}$ - energia livre de Gibbs

$\boldsymbol{\omega}$ - taxa de maturação de Ostwald

C* - intensidade de cor (Croma)

H* - ângulo de Hue

$\mathbf{L}^{*}$ - luminosidade

a* - teor de vermelho

$\mathbf{b}^{*}$ - teor de amarelo

$\Delta \mathbf{E}$ - diferença total de cor entre o início e o fim do armazenamento 


\section{SUMÁRIO}

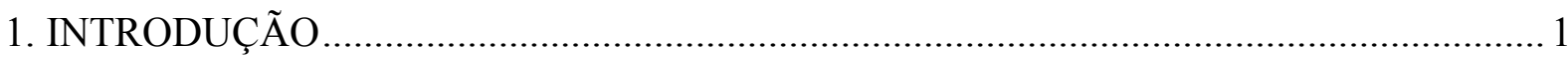

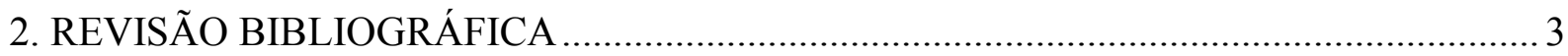

2.1 Atividade antibacteriana do óleo essencial de orégano ................................................... 3

2.2 Aplicação de óleos essenciais na conservação de alimentos ............................................... 5

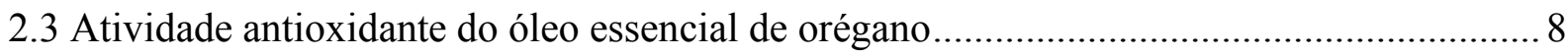

2.4 Nanoemulsões: definição, estabilidade e aplicação em alimentos .................................... 10

2.5 Métodos de produção de nanoemulsões ......................................................................... 15

2.5.1 Emulsificação pelo método da temperatura de inversão de fases (PIT - phase inversion

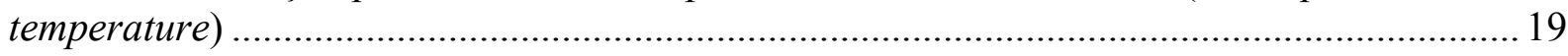

2.6 Encapsulação de óleos essenciais em sistemas lipídicos nanoestruturados .......................24

2.7 Patê

2.8 Fatores que afetam a qualidade de produtos cárneos durante a vida de prateleira .............27

2.8.1 Multiplicação bacteriana em produtos cárneos .......................................................... 27

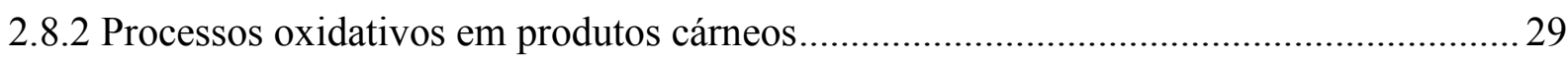

2.8.2.1 Métodos para determinação de oxidação lipídica em produtos cárneos ....................... 31

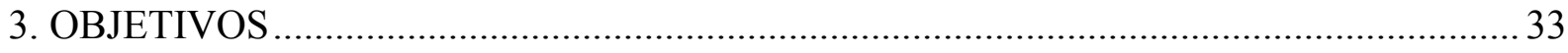

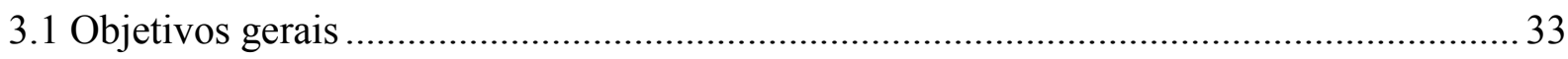

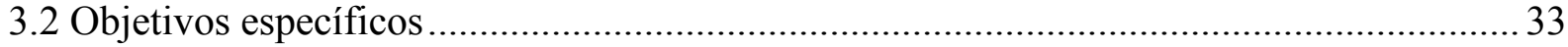

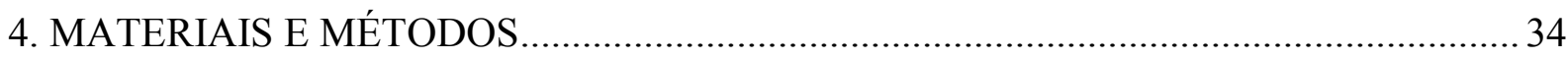

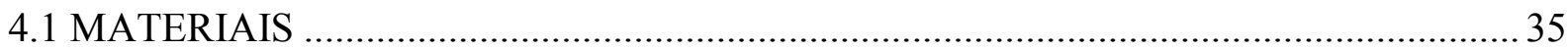

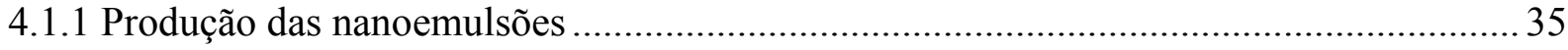

4.1.2 Quantificação dos componentes presentes no óleo essencial de orégano encapsulado .. 36

4.1.3 Análises de atividade antibacteriana in vitro das nanoemulsões ................................... 36

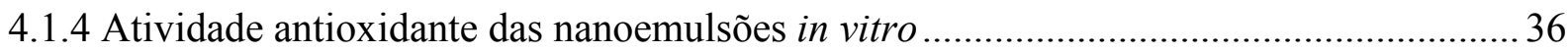

4.1.5 Produção do patê de frango .................................................................................... 37

4.1.6 Análises microbiológicas no patê de frango: determinação da vida de prateleira e determinação da qualidade microbiológica para análise sensorial ..........................................37

4.1.7 Atividade antibacteriana das nanoemulsões no patê de frango .................................... 37 


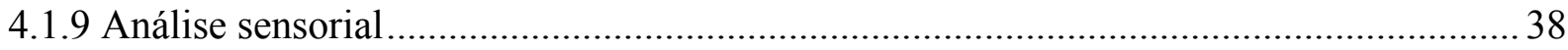

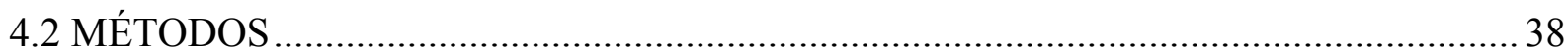

4.2.1 Produção das nanoemulsões encapsulando óleo essencial de orégano pelo método da temperatura de inversão de fases (PIT - phase inversion temperature) ................................... 38

4.2.2 Determinação da temperatura de inversão de fases das nanoemulsões .......................... 39

4.2.3 Determinação de diâmetro médio de gota, polidispersidade e distribuição de tamnho de

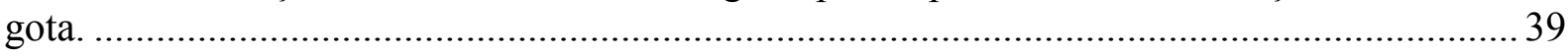

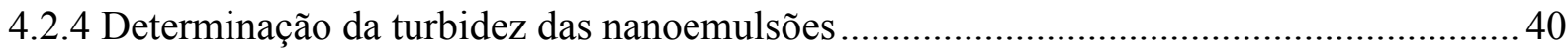

4.2.5 Quantificação dos compostos encapsulados por cromatografia gasosa ......................... 40

4.2.6 Determinação da atividade antibacteriana in vitro das nanoemulsões ........................... 41

4.2.7 Cinética da multiplicação in vitro das bactérias ............................................................. 42

4.2.8 Atividade antioxidante in vitro do oléo essencial de orégano não-emulsionado ............ 42

4.2.9 Atividade antioxidante in vitro do óleo essencial de orégano nanoemulsionado............ 42

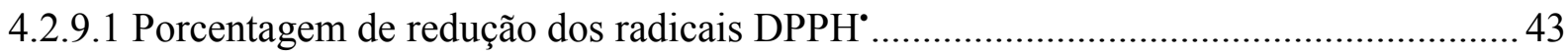

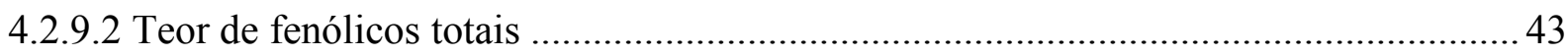

4.2.10 Produção e formulação do patê de frango ..................................................................... 44

4.2.11 Desenho experimental do processamento do patê de frango ...................................... 44

4.2.12 Determinação da composição centesimal do patê de frango .......................................... 45

4.2.13 Análises microbiológicas do patê de frango durante o armazenamento: Enterobactérias, contagem de micro-organismos viáveis totais e bactérias aeróbias psicrotróficas...................45

4.2.14 Atividade antibacteriana das nanoemulsões no patê de frango ................................... 46

4.2.15 Estabilidade físico-química do patê de frango durante o armazenamento .................... 47

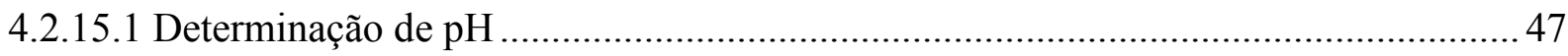

4.2.15.2 Determinação de parâmetros de colorimetria instrumental ....................................... 47

4.2.15.3 Avaliação da oxidação lipídica do patê de frango ................................................... 48

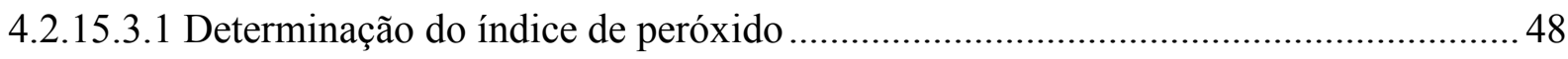

4.2.15.3.2 Determinação das substâncias reativas ao ácido tiobarbitúrico (TBARS) ............. 49

4.2.15.4 Avaliação da oxidação proteica do patê de frango (quantificação de carbonilas totais) 
4.2.16 Análise sensorial do patê de frango 50

4.2.16.1 Análises microbiológicas do patê de frango para realização da análise sensorial......51

4.2.16.2 Avaliação do perfil dos provadores da análise sensorial .......................................... 52

4.2.16.3. Teste de diferença do controle (análise discriminativa) .........................................52

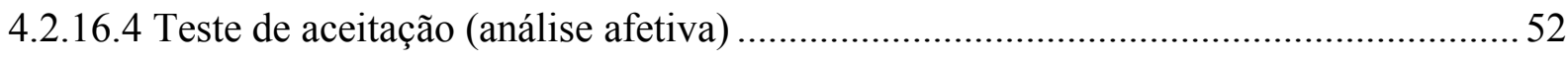

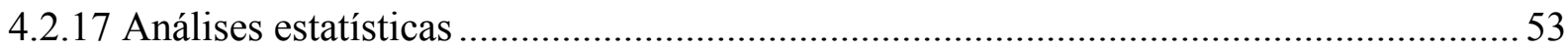

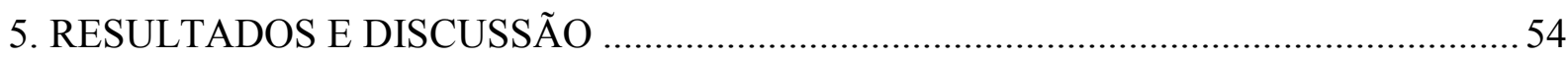

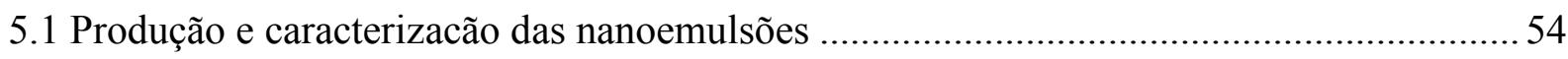

5.1.1 Determinação da temperatura de transição de fases na produção das nanoemulsões .....54

5.1.2 Avaliação da estabilidade físico-química das nanoemulsões durante a armazenagem ... 56

5.2 Quantificação dos compostos voláteis do OEO nanoemulsionado durante o armazenamento

5.3 Avaliação da atividade antimicrobiana in vitro das nanoemulsões .................................... 65

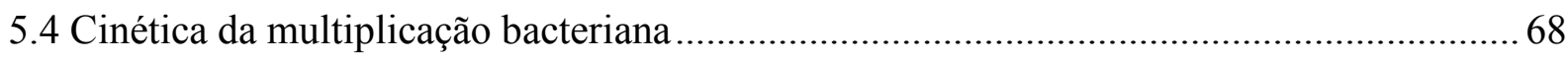

5.5 Capacidade antioxidante in vitro do OEO não-emulsionado ......................................... 70

5.6 Avaliação da atividade antioxidante in vitro das nanoemulsões ....................................... 71

5.6.1 Capacidade de redução dos radicais $\mathrm{DPPH}^{*}$ das nanoemulsões durante o

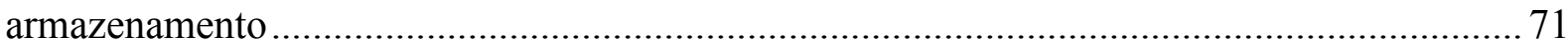

5.6.2 Determinação do teor de fenólicos totais das nanoemulsões durante o armazenamento 73

5.7 Caracterização físico-química do patê de frango: composição centesimal ........................ 74

5.8 Avaliação da qualidade microbiológica do patê de frango................................................ 77

5.9 Atividade antibacteriana das nanoemulsões no patê de frango ........................................ 78

5.10 Estabilidade físico-química do patê de frango durante o armazenamento ....................... 80

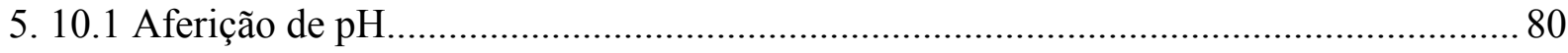

5.10.2 Determinação dos parâmetros colorimétricos .............................................................. 81

5.10.3 Oxidação proteica: quantificação do teor de carbonilas totais ..................................... 84

5.10.4 Oxidação lipídica: índice de peróxido e substâncias reativas ao ácido tiobarbitúrico

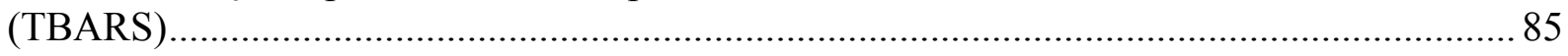

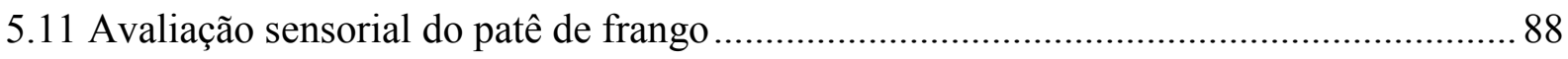


5.11.1 Análise microbiológica do patê de frango para realização da análise sensorial 88

5.11.2 Avaliação do perfil dos provadores 89

5.11.3 Análise sensorial - teste de diferença do controle (análise discriminativa) 91

5.11.4 Análise sensorial - teste de aceitação (análise afetiva) 93

5.11.5 Análise sensorial - teste de aceitação (análise afetiva) e intenção de compra. .96

6. CONCLUSÕES 101

7. SUGESTÕES PARA ESTUDOS FUTUROS 103

8. REFERÊNCIAS BIBLIOGRÁFICAS 104

APÊNDICE A - Termo de consentimento livre e esclarecido. 124

APÊNDICE B - Ficha de Avaliação do consumidor. 125

APÊNDICE C - Ficha de avaliação sensorial do patê de frango: teste de diferença do controle 126

APÊNDICE D - Ficha de avaliação sensorial do patê de frango: teste de aceitação (análise de odor e cor para correlacionar a aceitação com a oxidação do produto)

APÊNDICE E - Ficha de avaliação sensorial do patê de frango: teste de aceitação e intenção de compra. 128 


\section{INTRODUÇÃO}

Os óleos essenciais são misturas de compostos formados pelo metabolismo secundário de plantas aromáticas obtidos de flores, folhas, raízes ou cascas, sendo caracterizados por alta volatilidade e por composições complexas. As propriedades antioxidantes e antimicrobianas de vários óleos essenciais têm sido de grande interesse devido ao seu potencial uso como aditivos naturais para a prevenção de oxidação, controle de agentes patogênicos e/ou micro-organismos produtores de toxinas em alimentos. O óleo essencial de orégano (OEO) apresenta em sua composição compostos fenólicos, como carvacrol e timol, que conferem ação antibacteriana e antioxidante a este óleo, e portanto, o OEO pode ser considerado um potencial substituto efetivo aos conservantes e antioxidantes sintéticos, os quais são utilizados amplamente na indústria de alimentos e que podem ser danosos à saúde.

Tal necessidade de substituição se deve ao crescente interesse do mercado consumidor por produtos contendo menos aditivos artificiais, e tem impulsionado a pesquisa com produtos naturais, como, por exemplo, os extratos vegetais. Dentre as diferentes estratégias que podem ser aplicadas para controlar a contaminação de alimentos por micro-organismos patogênicos e a oxidação de produtos alimentares, a utilização de óleos essenciais, salvo algumas exceções, é uma alternativa segura e eficaz aos aditivos artificais.

Em relação à tecnologia de aplicação dos óleos essenciais nos alimentos, uma grande desvantagem é sua limitada solubilidade em meio aquoso, além de sua limitada vida de prateleira devido à alta volatilidade dos compostos. Portanto, uma alternativa para se contornar tais problemas é a microencapsulação, sendo a encapsulação de óleos essenciais em sistemas nanoemulsionados uma das técnicas que podem ser utilizadas. As nanoemulsões são emulsões com gotas de tamanho médio na faixa de 20 a 200 nm, e, devido à esta característica, podem ser sistemas translúcidos (caso o diâmetro médio de gota esteja abaixo de $\sim 80 \mathrm{~nm}$ ) e possuem baixa estabilidade termodinâmica. Além disso, exibem alta estabilidade cinética, o que os pode manter estáveis por um longo tempo de armazenagem. Adicionalmente, a baixa viscosidade e transparência óptica os fazem extremamente atraentes para utilização na área de alimentos.

A formação das nanoemulsões envolve a adição de energia, a qual pode ser inserida no sistema por forças mecânicas (métodos de alta energia) ou por processos físicos-químicos (métodos de baixa energia). Um dos métodos de baixa energia empregados na produção das nanoemulsões é o método da temperatura de inversão de fases (PIT - phase inversion 
temperature), o qual é baseado na diferença de solubilidade do tensoativo durante o aquecimento e o resfriamento do sistema tensoativo-óleo-água. Tal método permite obter dispersões coloidais oticamente transparentes devido à capacidade de produzir nanoemulsões com tamanho de gotas muito reduzido e com baixa polidispersidade. Especificamente na área de alimentos, há um recente e crescente interesse em sua utilização, sendo que diversos estudos na literatura versam sobre a produção e caracterização de sistemas nanoemulsionados que podem ser úteis para aplicações em formulações alimentícias, inclusive encapsulando óleos essenciais.

O patê de frango é um produto cárneo rico em nutrientes e apresenta elevado teor de lipídios em sua composição, o que o torna um alimento muito suscetível à contaminação microbiológica e à oxidação lipídica, os quais são os principais fatores que acarretam na perda da qualidade deste produto. A contaminação microbiana reduz a vida de prateleira dos produtos cárneos, possibilitando também a veiculação de patógenos, os quais apresentam potenciais riscos à saúde do consumidor. As principais fontes de contaminação de produtos cárneos estão relacionadas com a contaminação inicial das matérias-primas, com as baixas condições higiênicas durante o processamento e pelo tratamento térmico ineficiente.

Já a ocorrência de processos oxidativos em um produto cárneo, durante o armazenamento, pode gerar a degradação dos pigmentos, dos lipídios e das proteínas, alterando o sabor, a textura, a cor e o valor nutricional destes produtos. Entretanto, o reconhecido efeito prejudicial à saúde dos consumidores pela utilização dos antioxidantes sintéticos nos alimentos, como BHT (hidroxitolueno butilado), BHA (hidroxianisol butilado), PG (propil galato), TBHQ (Butil hidroquinona terciária) tornou eminente o interesse em estudos de aditivos naturais como potenciais antioxidantes.

Contudo, a incorporação de óleos essenciais em matrizes alimentícias pode ser limitada devido às suas propriedades de sabor e aroma, as quais podem conferir sabores desagradáveis aos alimentos. Por isso, há uma crescente necessidade de estudos que determinem as concentrações destes óleos, os quais conferem ação antimicrobiana e antioxidante, sem acarretar em alterações nas características organolépticas dos alimentos. 


\section{REVISÃO BIBLIOGRÁFICA}

\subsection{Atividade antibacteriana do óleo essencial de orégano}

Um óleo essencial (EO) é um líquido hidrofóbico com um aroma característico, o qual é atribuído aos seus compostos voláteis (RODRIGUEZ-GARCIA et al., 2016). Estes óleos são formados por metabólitos secundários de plantas aromáticas, e, atualmente, são conhecidos aproximadamente 3000 óleos essenciais, dos quais 300 são comercializados especialmente para as indústrias farmacêutica, de alimentos, agronômica, cosmética e de perfumaria (BURT, 2004; BAKKALI et al., 2008).

Diversos óleos essenciais têm demonstrado elevada atividade antibacteriana, antiviral e antifúngica, o que torna interessante a aplicação dos óleo essenciais como aditivos antimicrobianos naturais, para prolongar a vida de prateleira de alimentos e bebidas (CHANG; MCLANDSBOROUGH; MCCLEMENTS, 2015). As propriedades antimicrobianas dos óleos essenciais estão atribuídas aos componentes fenólicos (p.ex., timol, carvacrol, eugenol, mentol) e diversos trabalhos na literatura apresentam dados de composição de diversos óleos essenciais, sendo que os compostos neles presentes são de diversas classes químicas, havendo predominância de terpenos (BURT, 2004; HAMMER; CARSON, 2011).

O óleo essencial de orégano (Origanum vulgare), no presente texto denominado OEO, contém como principais compostos ativos o carvacrol e o timol, e, em alguns casos, o $\gamma^{-}$ terpineno (Figura 1) (LAMBERT et al., 2001; RHAYOUR et al., 2003). O carvacrol, um dos principais componentes do $\mathrm{OEO}$, apresenta estrutura muito semelhante à do timol, tendo apenas o grupo hidroxila numa localização diferente no anel fenólico, conforme mostrado na Figura 1 (BURT, 2004). O modo de ação antibacteriana desses compostos tem despertado maior atenção dos pesquisadores, uma vez que ambas as substâncias atuam de modo a tornar a membrana celular permeável, pois são capazes de desintegrar a membrana externa de bactérias gramnegativas (LAMBERT et al., 2001; BURT, 2004). 
Figura 1. Estrutura química dos principais compostos que constituem o óleo essencial de orégano: carvacrol, timol e $\gamma$-terpineno.
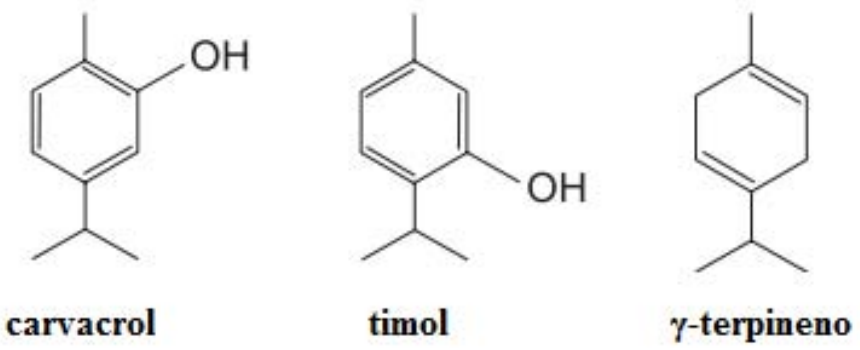

Fonte: Adaptado de Burt (2004).

O evidente interesse no uso deste $\mathrm{OE}$ na preservação de alimentos se deve ao fato de possuir um amplo espectro de atividade antimicrobiana (SOUZA et al., 2010). O timol tem conhecida atividade inibitória contra uma ampla gama de bactérias, incluindo Escherichia coli, Listeria monocytogenes e Staphylococcus aureus, Salmonella typhimurium e diversas leveduras, como Saccharomyces cereviseae. Por sua vez, o carvacrol é eficaz contra fungos, como Aspergillus, e bactérias patogênicas como Salmonella, Escherichia coli, Listeria monocytogenes e Bacillus cereus (GAYSINSKY, 2007; CARMO; LIMA; SOUZA, 2008). Todos estes micro-organismos são conhecidos por causar diversas doenças relacionadas com a ingestão de alimentos contaminados.

A ação antibacteriana dos óleos essenciais está relacionada com a estrutura química dos componentes, as quantidades em que estão presentes e as interações entre eles (DORMAN; DEANS, 2000; DELAQUIS et al, 2002). Alguns estudos concluíram que os óleos essenciais têm uma maior atividade antibacteriana do que os principais componentes individuais quando utilizados isoladamente (GILL et al., 2002, MOUREY; CANILLAC, 2002), o que sugere uma potencialização do efeito antibacteriano pelo efeito sinérgico entre os componentes (DAVIDSON; PARISH, 1989; BURT, 2004).

Embora a ação antimicrobiana dos óleos essenciais seja amplamente conhecida e comprovada, o(s) seu(s) mecanismo(s) de ação ainda não foi(ram) completamente determinado(s) (LAMBERT et al., 2001). De fato, considerando-se o grande número de diferentes compostos químicos presentes no $\mathrm{OE}$, o mais provável é que sua atividade antibacteriana não seja atribuível a um mecanismo específico, mas sim que existam vários alvos na célula (CARSON; MEE; RILEY, 2002). Os mecanismos mais comumente aceitos como responsáveis pela ação antimicrobiana são: a ocorrência de degradação da parede celular; 
ocorrência de danos à membrana citoplasmática e às proteínas da membrana; perda dos componentes celulares; coagulação do citoplasma e diminuição do fluxo de prótons através da membrana celular (BURT, 2004).

\subsection{Aplicação de óleos essenciais na conservação de alimentos}

A conservação de alimentos é uma necessidade que se tornou progressivamente mais complexa devido à crescente demanda dos consumidores por formulações contendo ingredientes alternativos e com baixos níveis de aditivos sintéticos (CAMPO et al., 2003; LEUSCHNER; ZAMPARINI, 2002). Tal interesse tem impulsionado a busca e a pesquisa da aplicação de produtos e extratos vegetais, com propriedades antimicrobianas, nos alimentos (BAHRAMI et al., 2016; RANJBAR; AZIZI, 2017; VAN HAUTE et al., 2017; CAETANO et al., 2017; GONÇALVES et al., 2017). Dentre as diferentes estratégias que podem ser aplicadas para controlar a contaminação de alimentos por micro-organismos patogênicos, a utilização de óleos essenciais é uma alternativa segura e eficaz aos conservantes químicos (LAMBERT et al., 2001).

Ambos os grupos de bactérias, tanto gram-negativas quanto gram-positivas, possuem suscetibilidade in vitro aos óleos essenciais e os óleos que mais atraem a atenção na área de alimentos são aqueles que inibem ou eliminam bactérias em concentrações menores que $1 \%$ v/v (10.000 ppm), sendo que tal nível de atividade é cerca de 1000 vezes maior que a atividade de antibióticos convencionais (CARSON; HAMMER, 2011).

A concentração necessária de tais conservantes naturais para ser considerada eficiente pode ser maior em produtos alimentícios quando comparados com os resultados de laboratório (in vitro), o que pode impactar negativamente as propriedades organolépticas dos alimentos (NEGI, 2012). Com isso, há uma demanda crescente pela determinação exata das concentrações inibitórias mínimas (CIM) de óleos essenciais, com a finalidade de permitir um equilíbrio entre a aceitabilidade sensorial e a ação antimicrobiana eficaz (LAMBERT et al., 2001), pois a extrapolação dos resultados obtidos a partir de experiências in vitro para alimentos não é simples, visto que se tratam de sistemas multicomponente complexos (NEGI, 2012).

Tais concentrações necessárias para inibir a multiplicação de patógenos em alimentos podem, muitas vezes, causar efeitos sensoriais desagradáveis para os consumidores. Portanto, o efeito organoléptico deve ser considerado na aplicação dos óleos essenciais como antimicrobianos em alimentos. A adição de pequenas quantidades de outros conservantes 
naturais em conjunto com o OE pode ser uma forma de proporcionar o equilíbrio entre a aceitabilidade sensorial e eficácia antimicrobiana (GUTIERREZ; BARRY-RYAN; BOURKE, 2008; NAVEENA et al., 2006).

Diversos estudos avaliaram o efeito nas propriedades sensoriais do alimento após a adição do OEO. A influência nas propriedades sensoriais do OEO, nas concentrações de 0,1 e 0,3\% (v/p), em carne de cordeiro foi avaliada por Karabagias, Badeka e Kontominas (2011). Inicialmente foi avaliada a atividade antimicrobiana do OEO pela contagem de microorganismos viáveis totais e, posteriormente, a análise sensorial de odor e sabor mostrou que, apenas na concentração mais elevada $(0,3 \% \mathrm{v} / \mathrm{p})$, o $\mathrm{OEO}$ conferiu odor e sabor muito forte à carne de cordeiro cozida, tornando o produto inaceitável pelo consumidor.

A atividade antimicrobiana de OEO puro e misturado com quitosana em carne de porco foi determinada por Paparella et al. (2016). Para isso, foram preparados tratamentos com adição de quitosana pura $(1 \% \mathrm{v} / \mathrm{v})$, OEO $(2$ e $4 \% \mathrm{v} / \mathrm{v})$ e mistura de quitosana com OEO, também nas concentrações de 2 e $4 \%$ de OEO. O tratamento contendo quitosana e $4 \%$ de OEO foi o que apresentou maior capacidade de redução na multiplicação de Listeria monocytogenes, Pseudomonas spp., bactéria ácido lática, Brochothrix thermosphacta e contagem de microorganismos viáveis totais ao longo de 15 dias de armazenamento. A análise sensorial dos tratamentos contendo $4 \%$ de OEO, com e sem quitosana, em relação ao controle (sem quitosana e OEO) mostrou que houve diferença significativa $(\mathrm{p}<0,001)$ para ambos os tratamentos em comparação com o controle, entretando apenas o tratamento com OEO sem quitosana apresentou sabor amargo, indicando que a quitosana atenuou esta característica no sabor da carne.

Hernández et al. (2017) avaliaram a atividade antimicrobiana do OEO para Salmonella enteritidis e Escherichia coli, em carne seca, e após 6 h de secagem, obtiveram valores de CIM de $0,038 \mathrm{~mL} / \mathrm{L}$ e $0,028 \mathrm{~mL} / \mathrm{L}$, respectivamente. A análise sensorial do produto mostrou que a concentração de $0,028 \mathrm{~mL} / \mathrm{L}$ de $\mathrm{OEO}$ afetou a qualidade sensorial da carne seca, sendo que apenas a amostra contendo $0,014 \mathrm{~mL} / \mathrm{L}$ apresentou melhor aceitação do consumidor em relação à amostra controle (sem OEO). Portanto, como as CIM determinadas para as bactérias em estudo foram superiores à $0,014 \mathrm{~mL} / \mathrm{L}$, a qual foi considerada aceitável pelos provadores, os autores sugeriram a aplicação do OEO em combinação com outro conservante natural para atingir atividade antimicrobiana necessária para inibir a multiplicação das bactérias em estudo. 
Do ponto de vista tecnológico de aplicação dos óleos essenciais, uma grande desvantagem é sua limitada solubilidade em meio aquoso. Com a finalidade de contornar tal desvantagem, a microencapsulação tem sido proposta como alternativa, visando, além de aumentar a solubilidade dos óleos essenciais em formulações aquosas, o aumento da sua estabilidade química durante o tempo de armazenagem e, em alguns casos, a melhora da sua ação antimicrobiana (DE MORAES et al., 2006). Sistemas coloidais, como as nanoemulsões, são alternativas promissoras para se alcançar os objetivos citados.

O encapsulamento de óleos essenciais em nanoescala representa uma abordagem viável e eficaz para aumentar a estabilidade dos compostos bioativos, protegendo-os das interações com os ingredientes alimentares e, devido ao seu tamanho subcelular, nos alimentos, as nanoemulsões podem aumentar a sua bioatividade através do mecanismo passivo de ativação de absorção celular (WEISS et al., 2009).

As nanoemulsões podem interagir com as membranas das células microbianas através de quatro vias principais, esquematizadas na Figura 2 (DONSİ; FERRARI, 2016):

(1) Transporte passivo através da membrana celular - as pequenas gotas de nanoemulsões são capazes de transportar o OE para a superfície da membrana celular, melhorando a acessibilidade às células microbianas e permitindo a ruptura da membrana celular, possivelmente alterando a integridade da bicamada dos fosfolípidos ou interferindo com as proteínas de transporte ativas (MOGHIMI et al., 2016b);

(2) Fusão com a bicamada de fosfolipídio celular - a fusão das gotículas de nanoemulsões com a bicamada fosfolipídica da membrana celular provoca, provavelmente, a liberação direcionada dos óleos essenciais (DONSİ; FERRARI, 2016);

(3) Partição na fase aquosa - a liberação prolongada ao longo do tempo dos óleos essenciais pelas nanoemulsões conduzida pela partição do óleo essencial entre as gotículas de óleo e a fase aquosa, prolonga a atividade antimicrobiana dos óleos essenciais (DONSİ; FERRARI, 2016); e

(4) Interação eletrostática com a membrana celular - a interação eletrostática de gotas de nanoemulsões positivamente carregadas com paredes de células microbianas carregadas negativamente aumenta a ação do OE (CHANG; MCLANDSBOROUGH; McCLEMENTS, 2015). 
Figura 2. Esquema das diferentes rotas promovidas pelas nanoemulsões para a interação de óleo essencial com as membranas celulares microbianas: (1) Transporte passivo através da membrana celular, (2) Fusão com a bicamada de fosfolipídio celular, (3) Partição na fase aquosa, e (4) Interação eletrostática com a membrana celular.

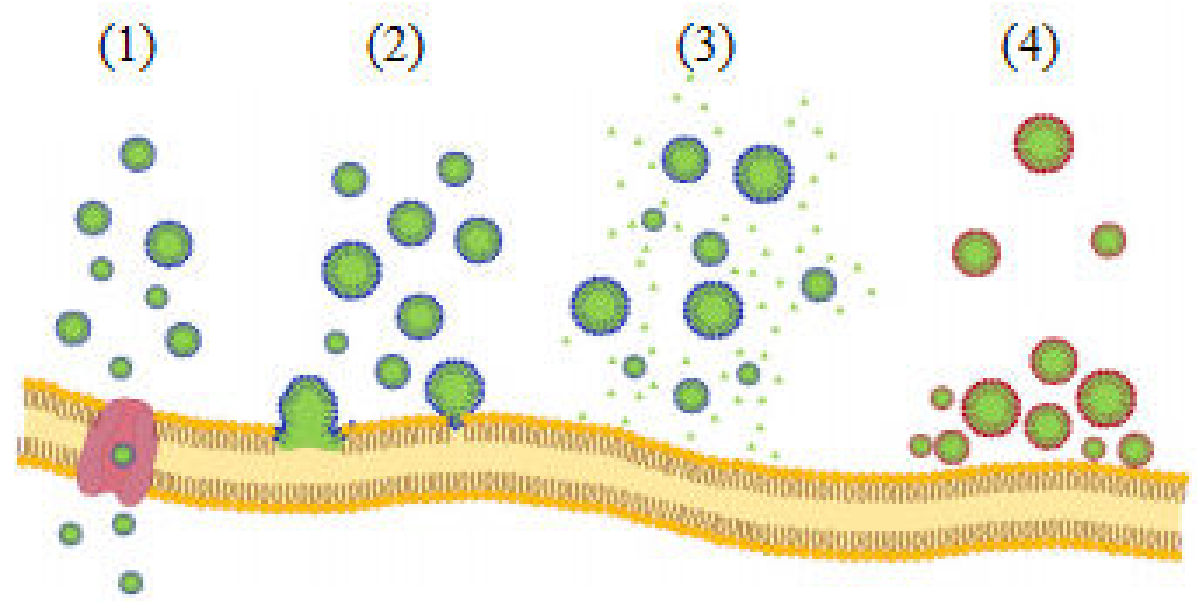

Fonte: Adaptado de Donsì e Ferrari (2016).

\subsection{Atividade antioxidante do óleo essencial de orégano}

Muitos antioxidantes de origem vegetal foram estudados, e entre estes, diversas plantas aromáticas e especiarias têm demonstraram sua eficácia no retardamento do processo de oxidação lipídica em óleos e alimentos com elevado teor de gordura, e com isso, ganharam o interesse de muitos grupos de pesquisa (KULISIC et al., 2004).

Segundo Kulisic et al. (2004), uma série de estudos sobre as atividades antioxidantes de óleos essenciais de várias plantas aromáticas relataram que o OEO, rico em timol e carvacrol, tem um efeito antioxidante considerável sobre o processo de oxidação lipídica, sendo que seu efeito antioxidante está relacionado com a presença de grupos hidroxilas na sua estrutura química. Os antioxidantes fenólicos extinguem os radicais livres derivados de oxigênio, assim como os radicais livres derivados de substrato, pela doação de um átomo de hidrogênio ou um elétron para o radical (BANDONIENE; MURKOVIC, 2002).

Stanojević et al. (2016) avaliaram a atividade antioxidade do OEO (Origanum vulgare) obtido por hidrodestilação e foi necessária uma concentração baixa de $\mathrm{OEO}, 0,326 \mathrm{mg} / \mathrm{mL}$, para a redução de 50\% da concentração inicial de radicais DPPH ${ }^{\bullet}$ (EC50 ou IC50). Os resultados obtidos neste trabalho indicaram que o OEO é uma boa fonte de antioxidantes naturais com 
potencial aplicação em alimentos, sendo, portanto, uma alternativa mais segura aos antioxidantes sintéticos.

Entretanto, a atividade antioxidante de óleos essenciais pode variar entre os estudos devido à composição dos mesmos, que depende da espécie do vegetal, da origem de cultivo e das estações de crescimento da planta (VAZIRIAN et al., 2015). Mechergui et al. (2016) avaliaram a atividade antioxidante do OEO coletado em diferentes anos (2007, 2008 e 2009) e de duas regiões do norte da Tunísia (Nefza e Krib). Na região de Nefza, entre os anos de 2007

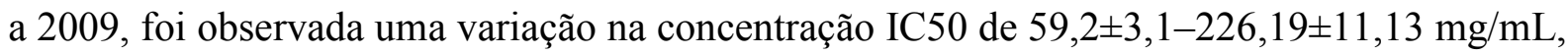

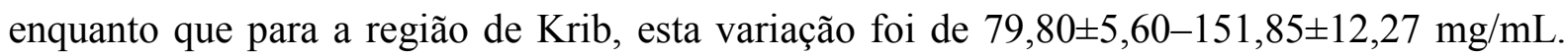
Portanto, devido às grandes variações na atividade antioxidadante do OE, que foi influenciada pelas condições climáticas, fica evidente a necessidade de determinar a atividade antioxidante do OEO em estudo.

A aplicação do OEO, com a função antioxidante, em alimentos é relatada em diversos trabalhos. Quiroga, Grosso e Nepote (2013) avaliaram o efeito antioxidante da adição de 0,02 $\%(\mathrm{~m} / \mathrm{m})$ de OEO em semente de girassol assada. Após 35 dias de armazenamento, foi possível observar que o OEO foi eficiente em reduzir o processo de oxidação em relação ao controle (sem antioxidantes) e inibir a formação de sabores indesejáveis, entretanto, o tratamento com adição do antioxidante sintético BHT mostrou maior proteção contra a oxidação. Além disso, os resultados obtidos na análise sensorial mostraram que não houve diferença significativa para os atributos de cor e textura, mas para odor e sabor, os tramentos controle e com BHT apresentaram maior aceitação do que o tratamento com adição de OEO.

Al-Hijazeen et al. (2016) avaliaram a atividade antioxidante da adição de OEO, nas concentrações de 0,01, 0,03 e 0,04 \% (m/m), em carne de peito de frango crua e cozida. Após 7 dias de armazenamento sob refrigeração, os autores observaram uma redução significativa ( $p$ $<0,05)$ na oxidação lipídica (TBARS) e proteica (quantificação de carbonilas), em relação ao controle (sem antioxidante), tanto na carne de frango crua quanto na cozida. Os resultados indicaram que OEO, em níveis de 0,01 a $0,04 \%$, poderia ser um potencial substituinte do antioxidante sintético na carne de frango.

A atividade antioxidante de revestimento comestível com adição de OEO em damasco fresco em pedaço, foi avaliada em um estudo realizado por Hashemi et al. (2017) e para isso, foram preparados filmes com concentrações de $0,1,2,3,4,5$ e $6 \%$ (v/v) de OEO. Após 8 dias do revestimento da fruta, os filmes contendo de 2 a $6 \%$ (v/v) de OEO apresentaram atividade 
antioxidante superior ao controle (sem antioxidante). A análise sensorial mostrou que a adição de OEO no filme, em todas as concentrações, melhorou o odor do damasco, sendo que foram atribuídas notas significativamente superiores $(p<0,05)$ para os tratamentos com OEO em relação ao controle (sem adição de OEO). Também foi possível observar que o filme com $6 \%$ (v/v) de OEO obteve maior aceitação sensorial e maior potencial antioxidante e antimicrobiano, indicando que este filme comestível poderia ser aplicado para manter a qualidade dos cortes de damasco frescos. Caetano et al. (2017) também observaram a ação antimicrobiana de filme comestível de pectina com adição de OEO $(2 \% \mathrm{~m} / \mathrm{v})$ em carne moída, sendo que a atividade de redução dos radicais $\mathrm{DPPH}^{\bullet}$ foi significativamente maior $(\mathrm{p}<0,05)$ no filme com adição de $\operatorname{OEO}(58,4 \pm 0.3 \%)$ em relação ao filme controle $(13,0 \pm 0,6 \%)$.

\subsection{Nanoemulsões: definição, estabilidade e aplicação em alimentos}

Sistemas coloidais consistem em pequenas gotículas lipídicas dispersas em uma fase aquosa e são largamente utilizados no setor alimentício para encapsular componentes lipofílicos funcionais (OSTERTAG; WEISS; McCLEMENTS, 2012). Os três sistemas mais utilizados são as emulsões, as nanoemulsões e as microemulsões, sendo que suas principais diferenças são o tamanho do diâmetro das gotas e a estabilidade termodinâmica (Tabela 1) (OSTERTAG; WEISS; McCLEMENTS, 2012; KOMAIKO; McCLEMENTS, 2016).

Tabela 1. Classificação dos sistemas coloidais baseada no tamanho de diâmetro das gotas e na estabilidade termodinâmica.

\begin{tabular}{ccc}
\hline Sistemas coloidais & $\begin{array}{c}\text { Faixa de diâmetro médio de } \\
\text { gota }\end{array}$ & Estabilidade termodinâmica \\
\hline Emulsões & $>200 \mathrm{~nm}$ & Metaestável \\
Nanoemulsões & $<200 \mathrm{~nm}$ & Metaestável \\
Microemulsões & $<100 \mathrm{~nm}$ & Estável \\
\hline
\end{tabular}

Fonte: Adaptado de McClements e Rao (2011)

Nanoemulsões podem ser definidas como emulsões convencionais com tamanhos médios de gota em escala nanométricas (20-200 nm), e são classificadas de acordo com o tipo de sistema água-óleo, sendo que um sistema que consiste em gotículas de óleo dispersas dentro 
de uma fase aquosa é determinado como uma nanoemulsão óleo em água $(\mathrm{O} / \mathrm{A})$, enquanto que uma nanoemulsão água em óleo $(\mathrm{A} / \mathrm{O})$ é constituída de gotículas de água dispersas em uma fase oleosa (TADROS et al., 2004; ANTON; VANDAMME, 2009; McCLEMENTS; RAO, 2011).

Em princípio, uma nanoemulsão pode ser formada a partir de óleo e água sem utilizar um tensoativo, entretanto, os tensoativos desempenham um papel importante na formação das nanoemulsões pois reduzem a tensão interfacial, prevenindo a coalescência de gotas recémformadas e portanto, a utilização de tensoativos é necessária para facilitar a formação das nanoemulsões e assegurar a sua estabilidade cinética durante o armazenamento (TRADOS et al. 2004; McCLEMENTS, 2004; McCLEMENTS, 2012). Usualmente, uma combinação de tensoativos em vez de um tensoativo único é usada para formar e estabilizar nanoemulsões, sendo que as nanoemulsões são preparadas utilizando os componentes: óleo, água e tensoativo (McCLEMENTS, 2012).

$\mathrm{Na}$ estrutura das nanoemulsões $\mathrm{O} / \mathrm{A}$, as caudas não-polares das moléculas de tensoativos ficam em torno do núcleo hidrofóbico formado pela fase oleosa, enquanto os grupos de cabeça polar das moléculas de tensoativo circundam a fase aquosa, de acordo com a Figura 3 (McCLEMENTS, 2012).

Figura 3. Diagrama esquemático da estrutura das nanoemulsões O/A formada a partir de óleo, água e tensoativo.

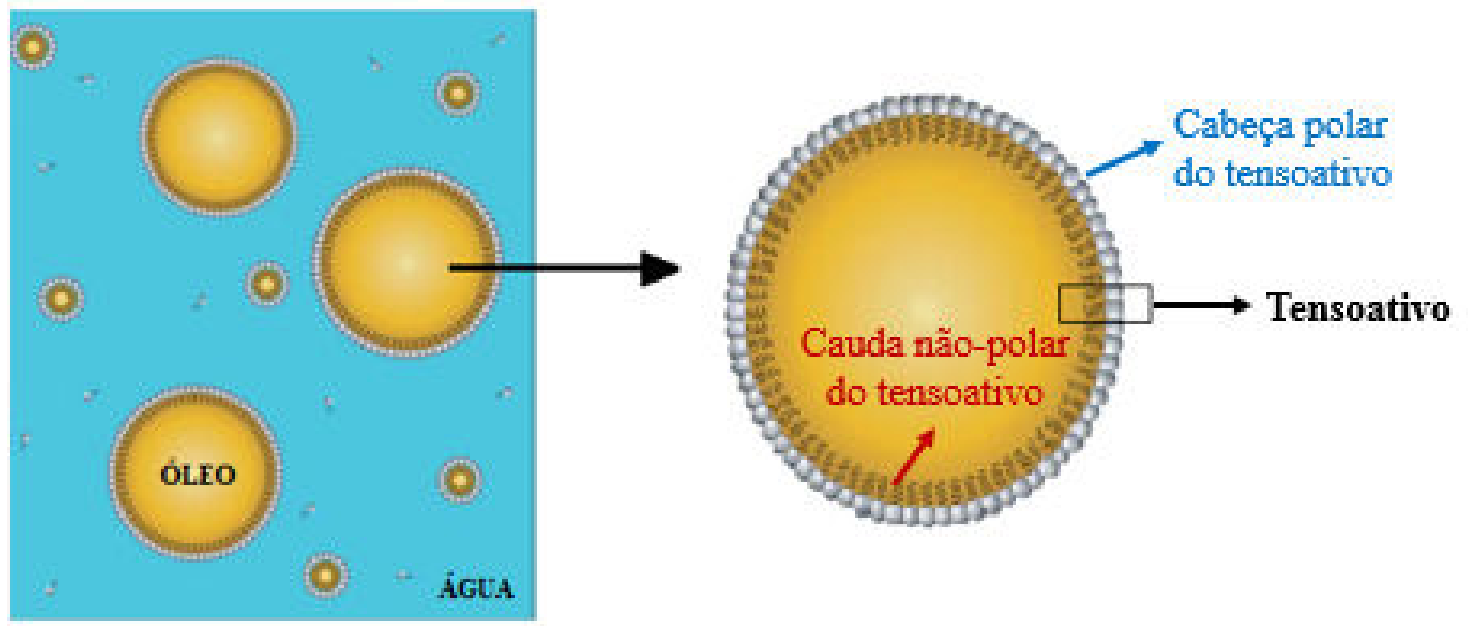

Fonte: Adaptado de McClements (2012). 
As nanoemulsões são sistemas termodinamicamente desfavoráveis devido à necessidade de variação de energia livre positiva para sua formação, a qual é associada à criação de uma interface entre as fases de óleo e água, e com isso, a energia livre da dispersão coloidal (gotículas de óleo na água) é maior do que a energia livre das fases separadas (óleo e água), conforme Figura 4 (McCLEMENTS; RAO, 2011; McCLEMENTS, 2012).

Figura 4. Diagrama esquemático da energia livre da formação de nanoemulsões $(\Delta \mathrm{G})$ : as nanoemulsões têm uma energia livre maior do que as fases separadas de água e óleo.

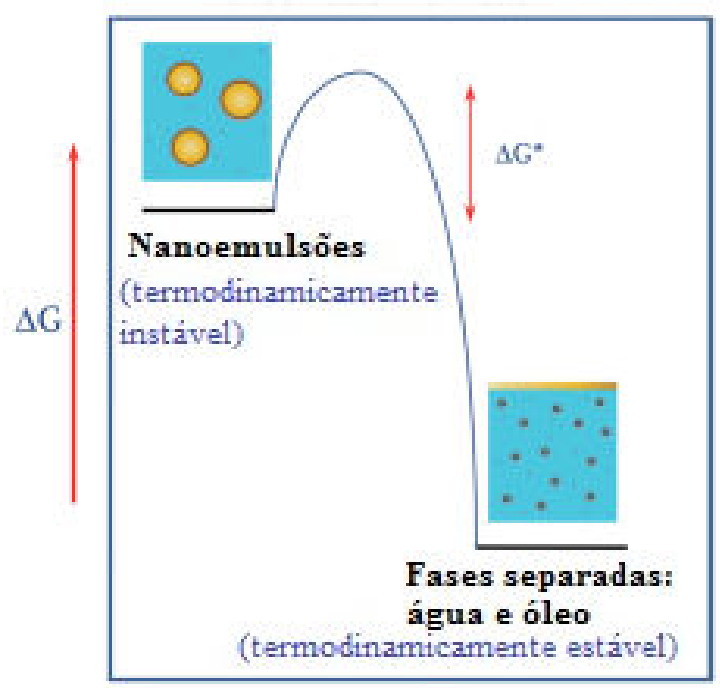

Fonte: Adaptado de McClements (2012).

Consequentemente, as nanoemulsões são sistemas metaestáveis que tendem à ruptura ao longo do tempo devido à vários fenômenos físico-químicos, como separação gravitacional (sedimentação ou cremeação), floculação e/ou coalescência e maturação de Ostwald (Figura 5) (McCLEMENTS; RAO, 2011). Entretanto, o pequeno tamanho de gotas das nanoemulsões: (i) provoca uma grande redução na força de gravidade e com isso, o movimento browniano pode ser suficiente para superar a gravidade, impedindo que ocorra a cremeação ou sedimentação do sistema; (ii) impede qualquer floculação das gotículas, permitindo que o sistema permaneça disperso (sem separação de fases); e (iii) impede a coalescência do sistema, uma vez que estas gotículas são resistentes à deformação (TADROS et al. 2004). 
Figura 5. Mecanismos físicos-químicos de desestabilização das nanoemulsões: separação gravitacional (sedimentação ou cremeação), floculação, coalescência ou maturação de Ostwald.

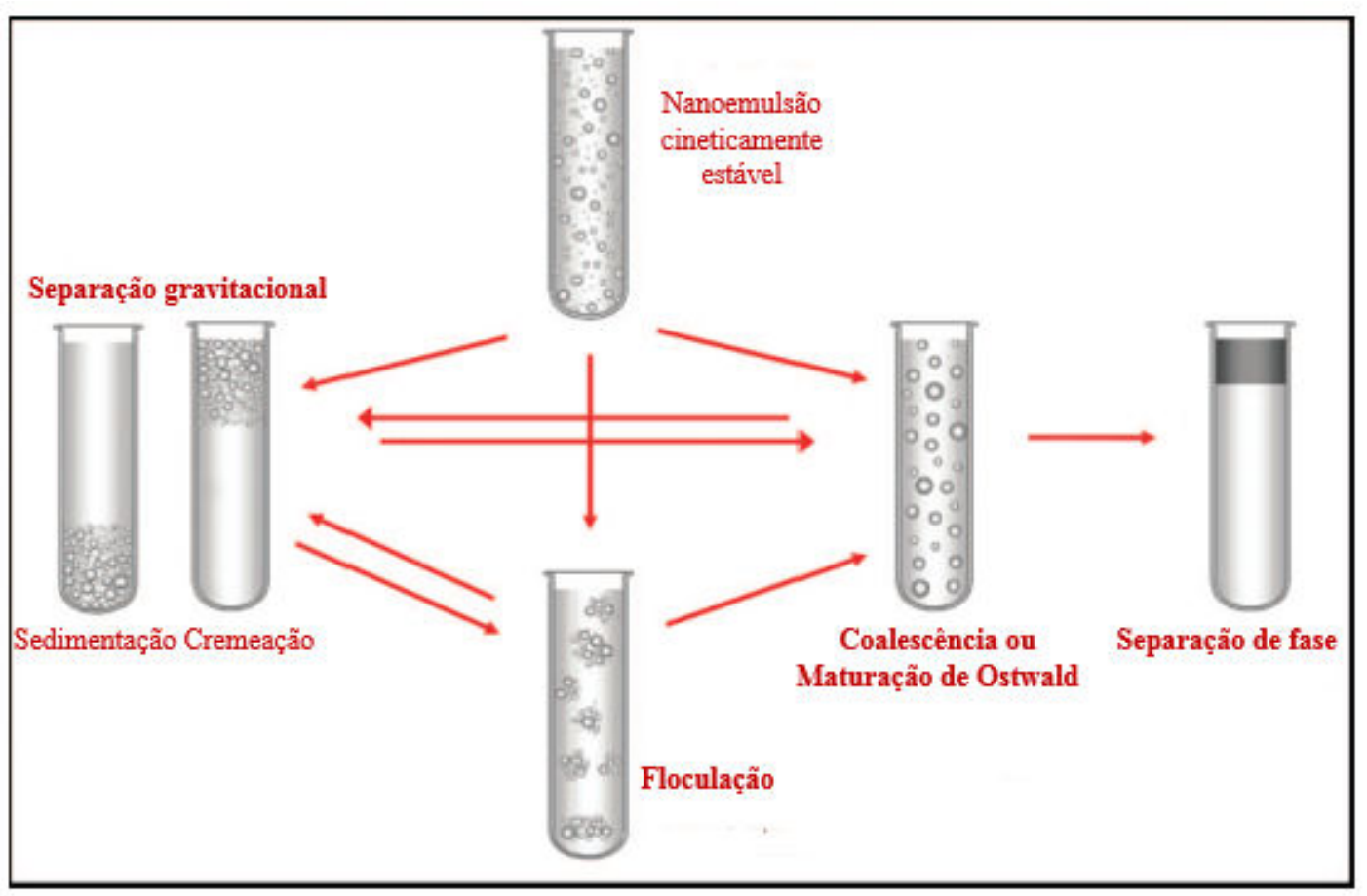

Fonte: Adaptado de McClements e Rao (2011).

Contudo, as nanoemulsões são particularmente propensas a um crescimento no tamanho das gotas ao longo do tempo por um processo conhecido como maturação de Ostwald (TADROS et al., 2004; CAPEK et al., 2004; KABALNOV, 2001), que é um processo pelo qual as gotas maiores de uma emulsão crescem em detrimento das gotas menores devido à difusão molecular do óleo entre gotas através da fase contínua (WOOSTER; GOLDING; SANGUANSRI, 2008). A taxa de maturação de Oswald, segundo a teoria de Lifshitz-Slyozov (1961) e Wagner (1961) (LSW), é uma relação linear da inclinação obtida pelo raio ao cubo (r ${ }^{3}$ ) e o tempo (t). A teoria LSW assume que: (i) as gotas da fase dispersa são esféricas; (ii) a distância entre as gotas é maior do que o diâmetro; (iii) e a cinética molecular é controlada pela difusão da fase dispersa na fase contínua (SOLANS et al., 2005). De acordo com esta teoria, a taxa de Ostwald em emulsões $\mathrm{O} / \mathrm{A}$ é diretamente proporcional à solubilidade do óleo na fase aquosa (SOLANS et al., 2005) e, portanto, a maturação de Oswald pode ser usada como uma ferramenta para avaliar a termodinâmica das soluções de óleos em água (TAYLOR, 2003). 
A utilização de nanoemulsões em alimentos apresenta algumas vantagens, pois as nanoemulsões são capazes de aumentar a biodisponibilidade das substâncias lipofílicas encapsuladas, e além disso, o tamanho reduzido das gotas torna o sistema nanoemulsionado transparente ou com baixa turbidez, o que permite aplicação das nanoemulsões nos alimentos sem influenciar nas propriedades óticas do produto (McCLEMENTS, 2010). Com isso, a aplicação de nanoemulsões na área de alimentos tem aumentado nos últimos anos e estudos recentes têm mostrado o potencial de aplicação das nanoemulsões no setor alimentício (Tabela 2).

Tabela 2. Estudos recentes sobre a aplicação de nanoemulsões em diversos tipos de alimentos.

\begin{tabular}{|c|c|c|c|c|}
\hline $\begin{array}{c}\text { Bioativo } \\
\text { encapsulado }\end{array}$ & Tensoativo & $\begin{array}{l}\text { Método de } \\
\text { produção }\end{array}$ & $\begin{array}{l}\text { Tipo de } \\
\text { alimento }\end{array}$ & Referência \\
\hline Eugenol & Tween 80 & $\begin{array}{l}\text { Cavitação } \\
\text { ultrassônica }\end{array}$ & $\begin{array}{l}\text { Suco de } \\
\text { laranja }\end{array}$ & $\begin{array}{c}\text { Ghosh; Mukherjee; } \\
\text { Chandrasekaran (2014) }\end{array}$ \\
\hline Trans-cinamaldeído & Tween 20 & $\begin{array}{c}\text { Homogeneização } \\
\text { à alta pressão }\end{array}$ & $\begin{array}{l}\text { Suco de } \\
\text { melancia }\end{array}$ & Jo et al. (2015) \\
\hline $\begin{array}{c}\text { Óleo essencial de } \\
\text { laranja }\end{array}$ & Tween 80 & $\begin{array}{c}\text { Homogeneizador } \\
\text { ultrassônico }\end{array}$ & $\begin{array}{l}\text { Suco de } \\
\text { maçãa }\end{array}$ & Sugumar et al. (2016) \\
\hline $\begin{array}{l}\text { Óleo essencial de } \\
\text { tomilho }\end{array}$ & DSD & Microfluidização & Leite & Jemaa et al. (2017) \\
\hline $\begin{array}{l}\text { Óleos de girassol, } \\
\text { avelã, canola, soja, } \\
\text { milho e oliva }\end{array}$ & Tween 80 & $\begin{array}{c}\text { Homogeneizador } \\
\text { ultrassônico }\end{array}$ & $\begin{array}{l}\text { Filé de } \\
\text { abadejo }\end{array}$ & Ozogul et al. (2017) \\
\hline Óleo de girassol & Tween 80 & $\begin{array}{c}\text { Homogeneizador } \\
\text { ultrassônico }\end{array}$ & $\begin{array}{l}\text { Filé de } \\
\text { truta }\end{array}$ & Shadman et al. (2017) \\
\hline Carvacrol & Tween 80 & $\begin{array}{c}\text { Homogeneização } \\
\text { à alta pressão ou } \\
\text { ultrassonica }\end{array}$ & $\begin{array}{l}\text { Repolho } \\
\text { picado }\end{array}$ & Sow et al. (2017) \\
\hline
\end{tabular}




\subsection{Métodos de produção de nanoemulsões}

A produção de nanoemulsões requer tipicamente óleo, água, tensoativo e emprego de energia, a qual pode ser mecânica ou físico-química. A energia livre requerida $(\Delta \mathrm{G})$ para formar uma nanoemulsão é definida a partir da Eq. (1) (KOMAIKO; McCLEMENTS, 2016):

$$
\Delta G=\Delta A \gamma-T \Delta S
$$

sendo:

$\Delta \mathrm{A} \gamma=$ energia livre necessária para aumentar interface $\mathrm{O} / \mathrm{A}$ (A representa a área interfacial e $\gamma$, a tensão interfacial);

$\mathrm{T} \Delta \mathrm{S}=$ energia livre associada ao aumento do número de arranjos possíveis de gotículas nas nanoemulsões em comparação com as fases separadas ( $\mathrm{T}$ é a temperatura e $\mathrm{S}$ é a entropia).

Em nanoemulsões, a mudança na entropia não é grande o suficiente para superar a energia necessária para expandir a interface e, portanto, o processo de formação de nanoemulsões requer outro tipo de energia livre (TADROS, 2004). Em métodos de alta energia, esta energia livre é adicionada por forças mecânicas aplicadas ao sistema, como cisalhamento, turbulência ou cavitação (KOMAIKO; McCLEMENTS, 2016), as quais podem ser geradas por equipamentos como homogeneizadores à alta pressão, microfluidizadores ou pela aplicação de altos níveis de energia ultrassônica (SPERNATH; MAGDASSI, 2007; ANTON et al., 2007; ANTON; BENOIT; SAULNIER et al., 2008a).

Em métodos de baixa energia, a energia livre, associada com a formação da interface nas nanoemulsões, provém de processos físico-químicos que ocorrem durante o processo de nanoemulsificação (KOMAIKO; McCLEMENTS, 2016). Tais métodos são mais eficientes do ponto de vista energético, uma vez que necessitam de uma menor energia empregada no sistema para produzir nanoemulsões com tamanho de gotículas menores em relação às nanoemulsões obtidas pelos métodos de alta energia (SOLANS; SOLÉ, 2012). Por outro lado, necessitam de quantidades maiores de tensoativos.

A produção de nanoemulsões por métodos de baixa energia pode ser realizada por metodologias classificadas em doLis tipos: (i) auto-emulsificação ou emulsificação espontânea e (ii) métodos de transição de fase (McCLEMENTS; RAO, 2011). De modo geral, na autoemulsificação o fenômeno ocorre devido a diversos fatores: (i) mudança de composição do sistema; (ii) variação de condições ambientais ( $\mathrm{pH}$, força iônica, temperatura); e (iii) condições 
de mistura (intensidade de agitação, taxa de adição dos componentes, ordem de adição dos componentes) (McCLEMENTS; RAO, 2011).

Nanoemulsões obtidas por métodos inversão de fases são produzidas utilizando-se a energia química interna do sistema, a qual é liberada durante a transição de fases que ocorre na conversão de uma emulsão O/A para emulsão de A/O ou vice-versa. (SOLANS; SOLÉ, 2012; McCLEMENTS; RAO, 2011). Estes métodos podem ser por: temperatura de inversão de fases (PIT), composição de inversão de fases (PIC) e ponto de inversão de emulsão (EIP) (OSTERTAG; WEISS; McCLEMENTS, 2012).

Os métodos de inversão de fases são de dois tipos: inversão de fases catastrófica ou transicional (JAHANZAD et al., 2009). No processo de inversão de fases catastrófica, a razão entre as fases oleosas e aquosas é alterada enquanto as propriedades do tensoativo são constantes, sendo que esta alteração é induzida pelo aumento ou pela diminuição da fração de volume da fase dispersa numa emulsão (MCCLEMENTS; RAO, 2011). Por sua vez, a inversão de fases por transição consiste na mudança de afinidade do tensoativo, entre as fases oleosa e aquosa, pela alteração da temperatura ou da composição da mistura de tensoativos a uma temperatura constante (JAHANZAD et al., 2009).

O desvio hidrofílico-lipofílico (HLD) é um parâmetro adimensional que caracteriza o comportamento de um tensoativo dentro de um sistema tensoativo-óleo-água, o qual considera a influência das propriedades da fase oleosa (como o tipo de óleo), as propriedades de fase aquosa (tais como teor de sal ou álcool) e os fatores ambientais (como a temperatura) na afinidade relativa de um tensoativo para as fases de óleo e água (McCLEMENTS; RAO, 2011). O número de HLD de um sistema tensoativo-óleo-água pode ser calculado utilizando a seguinte equação empírica (Eq. 2) para tensoativos não iônicos etoxilados (McCLEMENTS; RAO, 2011).

$$
H L D=[\alpha-k x E A C N-E O N]+\left[a x C_{A}+b x C_{S}+c x\left(T-T_{0}\right)\right]
$$

sendo:

$\alpha$ e $k=$ constantes que dependem do tipo de tensoativo;

$\mathrm{EACN}=$ número de carbonos alcano equivalente da fase oleosa;

EON = número de grupos etoxilados na cabeça do tensoativo; 
$\mathrm{C}_{\mathrm{A}}=$ concentração de qualquer álcool presente no sistema;

$a=$ constante que depende do tipo de álcool;

$\mathrm{C}_{\mathrm{s}}=$ concentração de qualquer sal presente no sistema;

$b=$ constante que depende do tipo de sal;

$\mathrm{T}=$ temperatura do sistema;

$\mathrm{T}_{0}=$ temperatura de referência $\left({ }^{\circ} \mathrm{C}\right)$, a qual normalmente é $25^{\circ} \mathrm{C}$;

$c=$ constante que depende da influência da temperatura nas propriedades de um tensoativo.

Para tensoativos iônicos, o valor de HLD pode ser calculado a partir da Eq. (3), na qual os parâmetros podem ser interpretados de acordo com a Eq. (2) (McCLEMENTS; RAO, 2011).

$$
H L D=\left[\alpha^{\prime}-k^{\prime} x E A C N-E O N\right]+\left[a^{\prime} x C_{A}+b^{\prime} x \ln \left(C_{S}\right)+c^{\prime} x\left(T-T_{0}\right)\right]
$$

Para $\mathrm{HLD}<0$, o tensoativo tem maior afinidade por água e estabiliza emulsões $\mathrm{O} / \mathrm{A}$, para HLD > 0, a afinidade do tensoativo é maior para o óleo e estabiliza emulsões $\mathrm{A} / \mathrm{O}$, entretanto, quando HLD $=0$, o tensoativo tem igual afinidade com a fase aquosa e com a fase oleosa, sendo que, nesse caso, uma microemulsão bicontínua ou uma fase cristalina líquida pode ser formada (OSTERTAG; WEISS; McCLEMENTS, 2012, PERAZZO; PREZIOSI; GUIDO 2015).

O diagrama mostrado na Figura 6 é o mapa bidimensional formulação-composição, que indica as inversões de fase transitória e catastrófica. No diagrama, o sinal $(+)$ e $(-)$ estão relacionados com o HLD da formulação, enquanto (B) corresponde a uma fase rica em óleo, (A) é uma fase intermediária entre água e óleo e (C) é uma fase rica em água (RONDÓNGONZÁLEZ et al., 2006; PERAZZO; PREZIOSI; GUIDO, 2015). A linha horizontal central correspondente a HLD $=0$ e um deslocamento no eixo vertical do diagrama representa uma variação do HLD da formulação do sistema, enquanto horizontalmente representa uma variação na composição de óleo e água (PERAZZO; PREZIOSI; GUIDO, 2015). Uma inversão de fases transicional ocorre entre duas emulsões cineticamente estáveis, que são representadas como $(\mathrm{A}+),(\mathrm{A}-),(\mathrm{B}+),(\mathrm{C}-)$ e em uma inversão de fases catastrófica, acontece a transição entre sistemas emulsionados estáveis e instáveis, regiões (B-) e (C+) (SAJJADI, 2006, PERAZZO; PREZIOSI; GUIDO, 2015). Nos métodos de temperatura de inversão de fases (PIT) e 
composição de inversão de fases (PIC), a mudança da emulsão $\mathrm{O} / \mathrm{A}$ para emulsão A/O, ou viceversa, é através de uma inversão de fases de transição, no método de ponto de inversão de emulsão (EIP), a inversão de fases é catastrófica (FERNANDEZ et al., 2004). Devido às vantagens dos métodos de baixa energia em relação ao rendimento, potencial para escala industrial e características não agressivas de produção, tem aumentado o interesse de pesquisas no desenvolvimento de tais métodos e técnicas nos últimos anos (ANTON; VANDAMME, 2009).

Figura 6. Diagrama do comportamento formulação-composição por inversão de fases transicional e catastrófica.

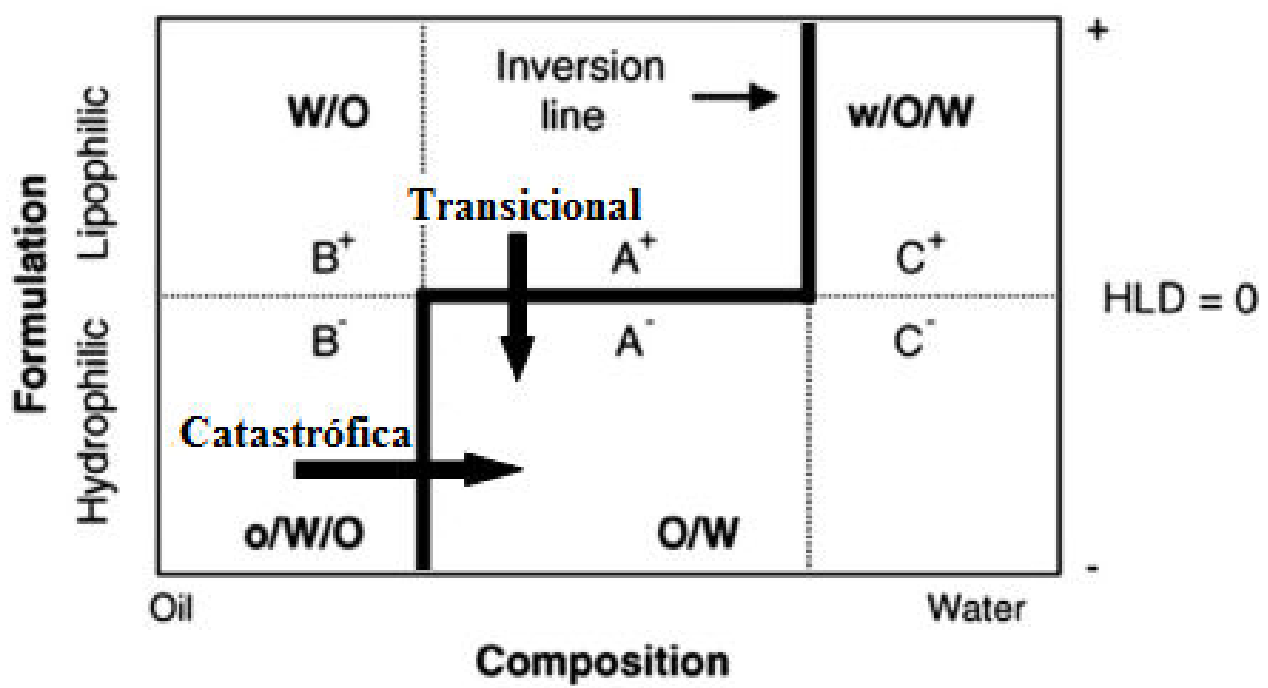

Fonte: Adaptado de Rondón-González et al. (2006).

Os tensoativos também podem ser classificados de acordo com a geometria da molécula, a qual pode ser caracterizada por um parâmetro de empacotamento (p), que é igual à razão entre as áreas de seção transversal da cauda $(\mathrm{aT})$ e da cabeça $(\mathrm{aH})$ do tensoativo: $\mathrm{p}=\mathrm{aT} / \mathrm{aH}$ (Figura 7) (KOMAIKO; McCLEMENTS, 2016). Este parâmetro determina a curvatura ideal que tende a ser adotada por um determinado tensoativo, sendo que, quando a área da cauda do tensoativo for maior do que a área da cabeça ( $\mathrm{p}>1)$, a monocamada dos tensoativos adota uma curvatura positiva (os grupos das caudas apontam para fora) e favorecem a formação de emulsões A/O. Por outro lado, quando a área da cabeça do tensoativo é maior do que o a área da cauda $(\mathrm{p}<1)$, 
ocorre a formação de uma curvatura negativa da monocamada do tensoativo (os grupos da cabeça apontam para fora), e portanto, favorece a formação de uma emulsão O/A. Entretanto, se as áreas de seção transversal da cabeça e da cauda do tensoativo forem iguais $(p=1)$, então a monocamada tende a ser plana, o que favorece a formação de bicamada lipídica (KOMAIKO; McCLEMENTS, 2016).

Figura 7. Diferentes tipos de sistemas coloidais que são formados de acordo com a geometria molecular dos tensoativos.

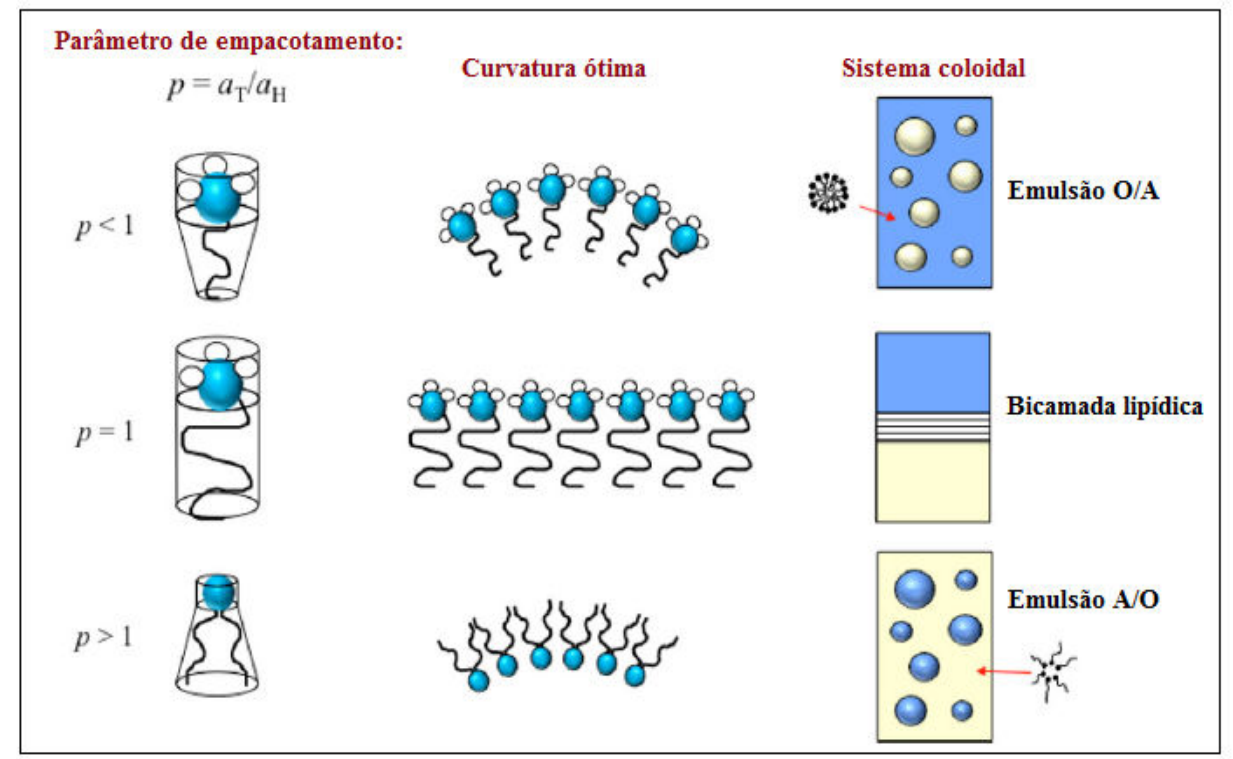

Fonte: Adaptado de Komaiko eMcClements (2016).

\subsubsection{Emulsificação pelo método da temperatura de inversão de fases (PIT - phase inversion temperature)}

O método PIT (do inglês, phase inversion temperature), introduzido por Shinoda e Saito (1968, 1969), se utiliza da característica dos tensoativos não-iônicos (mais especificamente, dos tensoativos polietoxilados) de alterar suas afinidades com a fase aquosa e com a fase oleosa de acordo com a temperatura, mantendo fixa a composição do sistema tensoativo-óleo-água SILVA; CERQUEIRA; VICENTE, 2012).

No método PIT (Figura 8) ocorre a alteração da curvatura espontânea do tensoativo com a mudança na temperatura do sistema. Em baixas temperaturas, a parte hidrofílica do tensoativo não-iônico é altamente hidratada, apresentando uma área maior em relação à parte hidrofóbica 
do tensoativo e consequentemente, a monocamada do tensoativo possui uma curvatura espontânea positiva, formando emulsões $\mathrm{O} / \mathrm{A}$. Um comportamento contrário é observado no tensoativo com o aumento da temperatura, onde ocorre a desidratação da parte hidrofílica do tensoativo, o qual apresenta uma curvatura espontânea negativa, e portanto, o sistema se torna emulsionado na forma A/O (FERNANDEZ et al., 2004; McCLEMENTS; RAO, 2011).

A temperatura de inversão de fases é a temperatura na qual o sistema tensoativo-óleoágua muda de uma emulsão $\mathrm{O} / \mathrm{A}$ para uma emulsão $\mathrm{A} / \mathrm{O}$, ou vice-versa. Nesta temperatura, na qual a solubilidade do tensoativo nas fases oleosa e aquosa é aproximadamente igual, o sistema atravessa um ponto de curvatura espontânea nula e tensão superficial mínima, formando estruturas de microemulsões bicontínuas, conforme Figura 8 (McCLEMENTS; RAO, 2011).

Figura 8. Diagrama esquemático da dependência da temperatura com a curvatura espontânea das monocamadas de tensoativo e sua influência nas propriedades de uma emulsão.

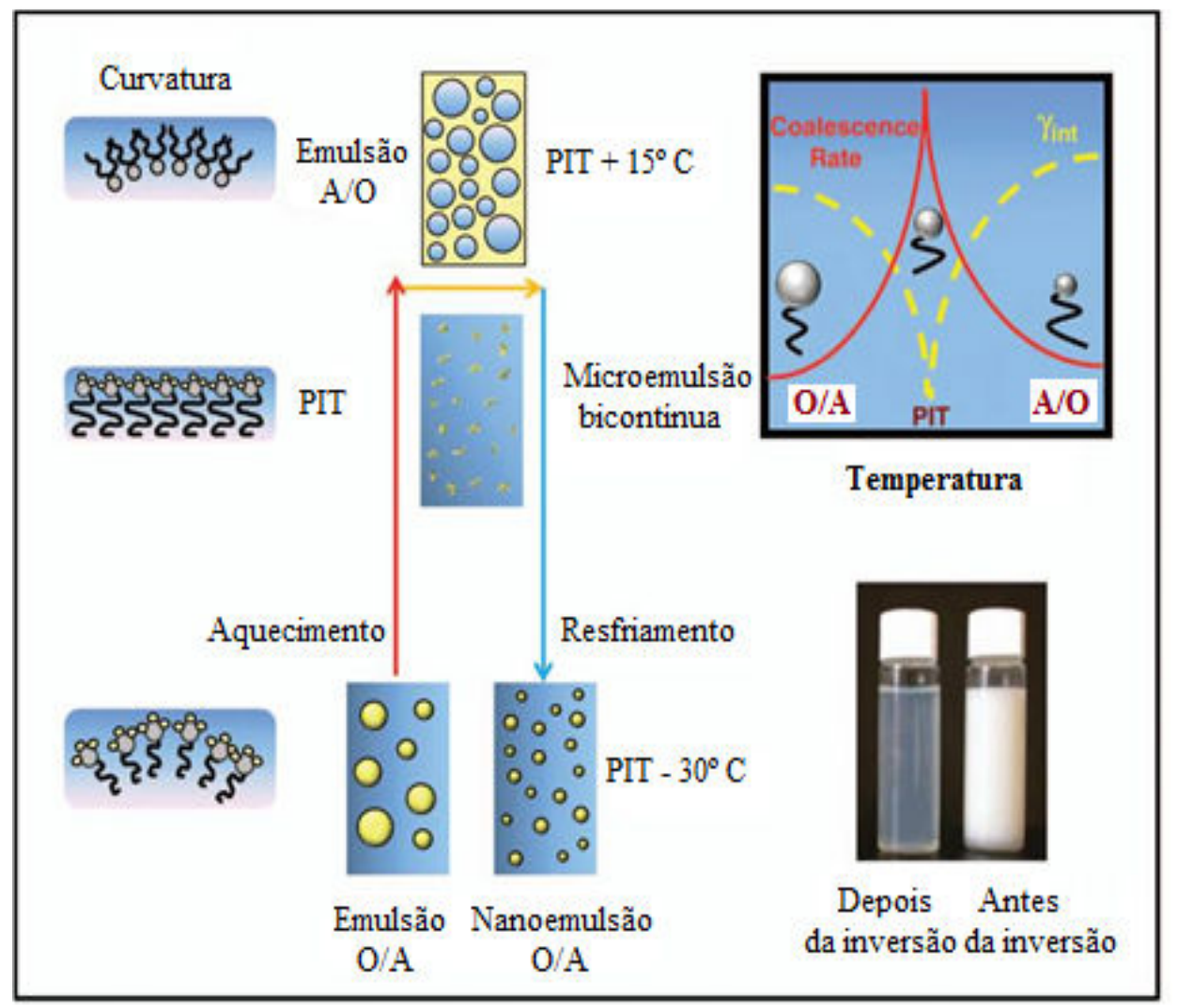

Fonte: Adaptado de McClements e Rao (2011). 
As nanoemulsões produzidas pelo método PIT são formadas conforme os mecanismos descritos na Figura 9. Inicialmente, a temperatura do sitema tesoativo-óleo-água está abaixo da temperatura de inversão de fases e ocorre a formação de uma macro-emulsão leitosa e a maioria dos tensoativos não-iônicos são solubilizados na fase aquosa (em baixas temperaturas o tensoativo é hidrofílico) (a). Com o aumento da temperatura do sistema os tensoativos tornamse gradualmente hidrofóbicos, fazendo com que migrem para dentro da fase oleosa (b). Em seguida, o sistema atinge a temperatura de inversão de fases, onde a curvatura e a tensão interfacial são reduzidas, dando origem a microemulsões bicontínuas, do tipo Winsor III (fase oleosa, aquosa e microemulsão bicontínua em equilíbrio) ou do tipo Winsor IV (fase única de microemulsão bicontínua) (c) (ANTON; VANDAMME, 2009). Finalmente, quando ocorre o resfriamento rápido de uma emulsão que se encontra na temperatura de inversão de fases, os tensoativos se tornam hidrofílicos, e consequentemente, sob agitação contínua do sistema, as moléculas do tensoativo se movem rapidamente da fase oleosa para a fase aquosa, sendo que, devido ao aumento da área de interface $\mathrm{O} / \mathrm{A}$ e à geração do fluxo turbulento interfacial, induz a formação espontânea de pequenas gotículas de óleo na fase aquosa, denominadas nanoemulsões (d) (McCLEMENTS; RAO, 2011). 
Figura 9. Mecanismo de geração das nanoemulsões pelo método PIT: (a) a temperatura está abaixo da temperatura de inversão de fases (emulsãoO/A); (b) ocorre o aumento da temperatura e os tensoativos se tornam gradualmente lipofílico (são solubilizados pela fase oleosa); (c) sistema está na temperatura de inversão de fases: microemulsões bicontínuas; e (d) resfriamento rápido do sistema tensoativo-óleoágua, onde ocorre a migração espontânea e rápida do óleo para a fase aquosa: formação das nanoemulsões.
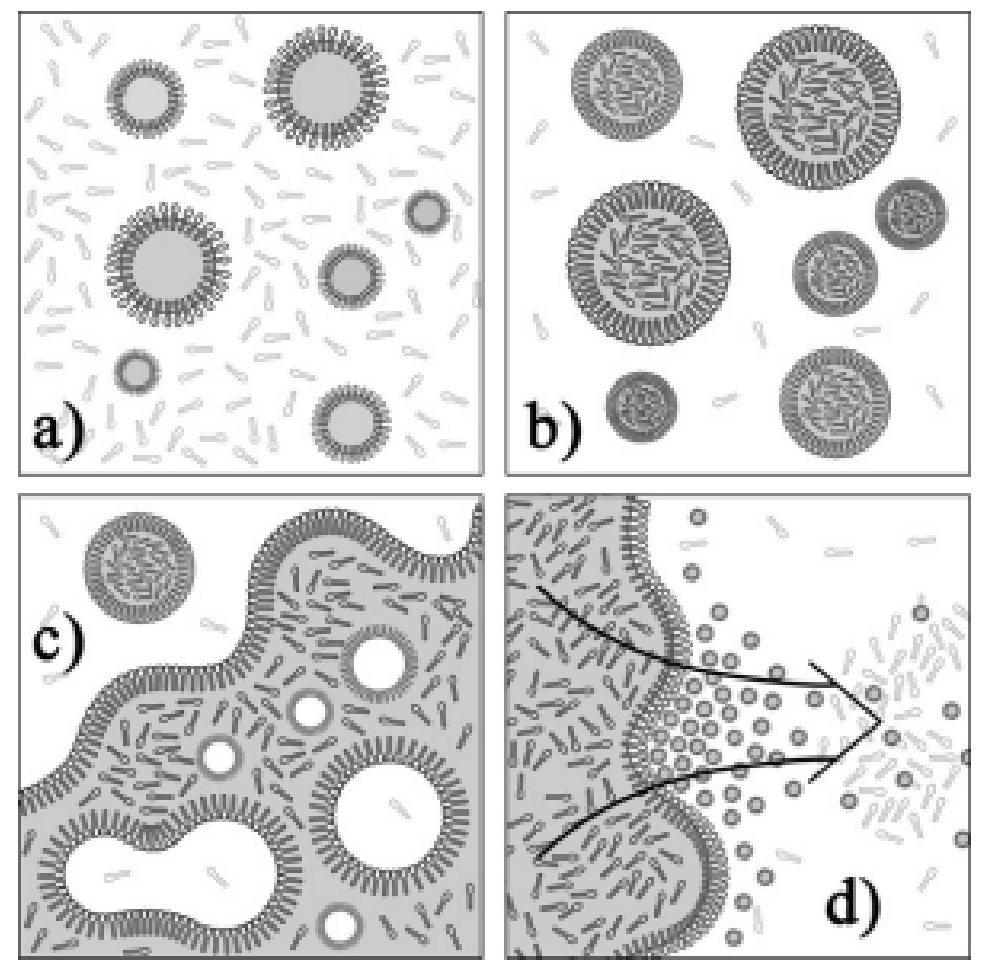

Fonte: Anton e Vandamme (2009).

Este método de produção das nanoemulsões apresenta algumas vantagens: (i) é capaz de produzir nanoemulsões cineticamente estáves; (ii) processo de produção é relativamente simples; (iii) impede a degradação do bioativo encapsulado durante o processamento; (iv) requer baixa quantidade de energia; e (v) fácil escala industrial (ANTON; BENOIT; SAULNIER, 2008b, SILVA; CERQUEIRA; VICENTE, 2012).

Entretanto, uma grande desvantagem do uso do método PIT para produção de nanoemulsões é a alta taxa de coalescência, fenômeno que pode ser extremamente rápido nas proximidades da zona de transição de fases, e para evitar tal problema, as taxas de resfriamento ou aquecimento das emulsões devem ser altas e bem controladas; caso contrário, a coalescência predominará e sistemas com diâmetro médio de gota acima de $200 \mathrm{~nm}$ e com alta 
polidispersidade serão formados (SALAGER, 2006; EE et al., 2008; RAO; McCLEMENTS, 2010).

Para utilizar o método PIT para produção de nanoemulsões, a temperatura de inversão de fases (PIT) precisa ser determinada. Tal determinação pode ser feita por diferentes métodos, como, condutividade elétrica, análise da microestrutura das emulsões, reologia (SALAGER, 2006) e, também, microcalorimetria (SOUZA et al., 2010). Os métodos mais difundidos para determinação da temperatura de inversão de fases são a condutivimetria e a reologia, e perfis típicos da alteração da condutividade e da viscosidade são mostrados na Figura 10. Tais alterações na condutividade e nas propriedades reológicas ocorrem devido à alteração da configuração do sistema emulsionado para um sistema estruturado em fase bicontínua ou lamelar, antes da inversão de fases $(\mathrm{O} / \mathrm{A}$ para $\mathrm{A} / \mathrm{O}$, no caso de aquecimento, ou vice-versa no caso de resfriamento).

Dentre os fatores que mais influenciam a inversão de fases estão: tipo de tensoativo (balanceamento da hidrofilicidade e da lipofilicidade), concentração de tensoativo, razão A/O, presença e concentração de sais, e, em alguns casos, a velocidade e a ordem de adição dos componentes da formulação (BROOKS et al., 1998; ALLOUCHE et al., 2004; ANTON; BENOIT; SAULNIER, 2008a). 
Figura 10. Mudanças na condutividade e na turbidez em função da temperatura, em uma inversão transicional.
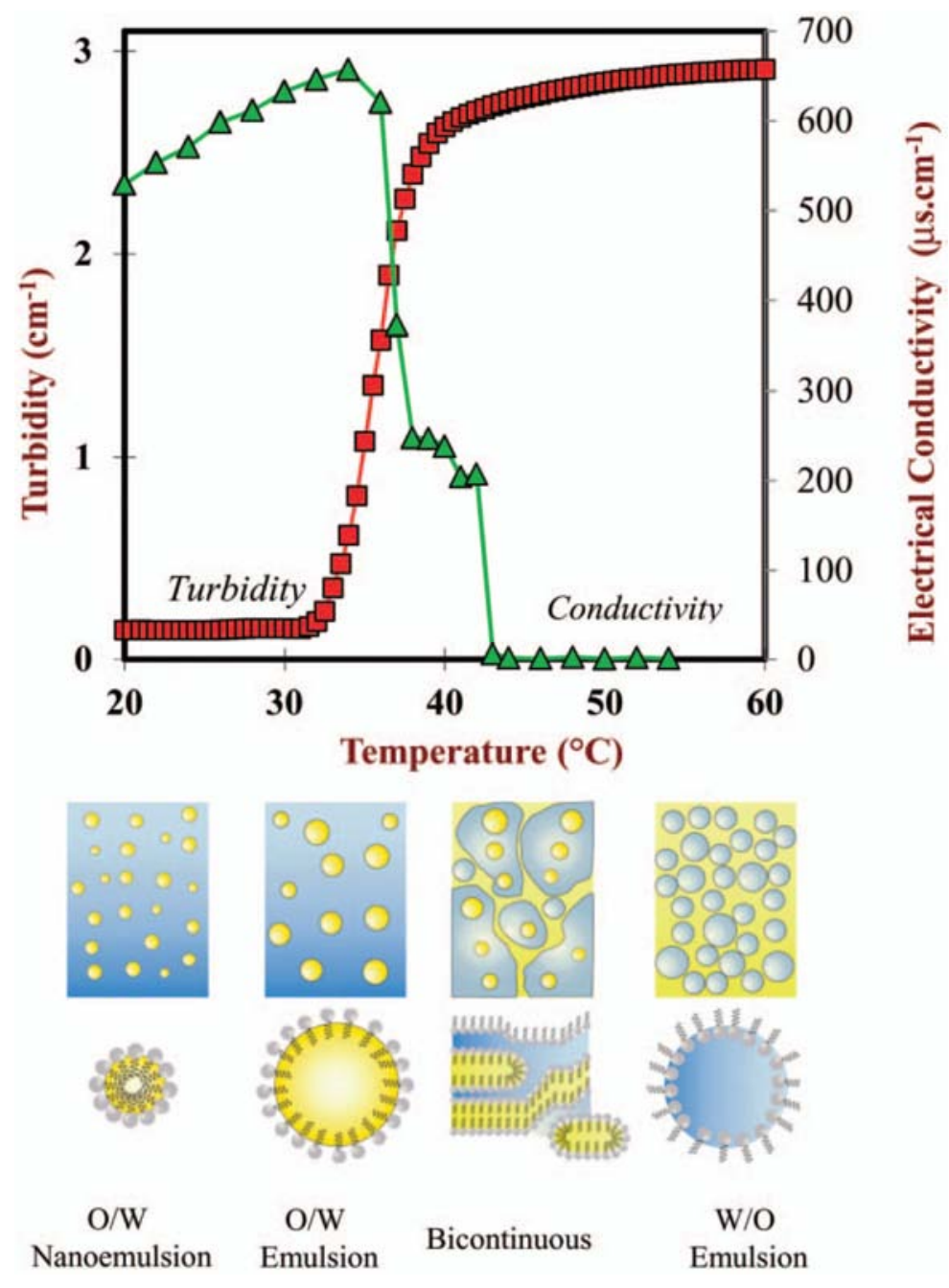

Fonte: McClements e Rao (2011).

\subsection{Encapsulação de óleos essenciais em sistemas lipídicos nanoestruturados}

Nanoemulsões têm sido empregadas em estudos para encapsulação de diferentes tipos de óleos essenciais, diversos deles visando investigar a ação antimicrobiana de tais nanosistemas. $\mathrm{O}$ interesse por tal abordagem vem crescendo nos últimos anos, mas os estudos ainda não são numerosos, sendo ainda menores os estudos utilizando o método PIT para produção das nanoemulsões, o que indica um imenso potencial para pesquisas na área.

Zhang et al. (2014) produziram nanoemulsões estáveis encapsulando D-limoneno (uma molécula presente em diversos óleos essenciais), pelo método de inversão de fases catastrófica, sem e com diferentes concentrações de nisina $(0,5,1,5,3,0 \% \mathrm{~m} / \mathrm{m})$, e as nanoemulsões 
apresentaram diâmetro médio de gota em torno de $20 \mathrm{~nm}$. Neste estudo foi avaliado o potencial antibacteriano das nanoemulsões de D-limoneno com e sem nisina, bem como o D-limoneno não-encapsulado, para os micro-organismos Staphylococcus aureus, Bacillus subtilis, Escherichia coli e Saccharomyces cerevisiae e verificou-se que, para os quatro microorganismos, as nanoemulsões de D-limoneno com nisina apresentaram um desempenho antimicrobiano maior do que as nanoemulsões de D-limoneno sem nisina, as quais foram superiores ao potencial antimicrobinano do D-limoneno não-encapsulado. Além disso, os autores observaram que as nanoemulsões de D-limoneno com nisina mostraram maior propriedade antibacteriana para as bactérias gram-positiva, S. aureus e B. subtilis, o qual foi atribuído ao efeito de sinergismos entre o D-limoneno e a nisina.

A atividade antimicrobiana de nanoemulsões produzidas por microfluidização encapsulando diversos tipos de óleos essenciais, como capim limão, cravo, tea tree, tomilho, gerânio, manjerona, palmarosa, jacarandá, sálvia e hortelã, foi avaliada em um trabalho realizado por Salvia-Trujillo et al. (2015). As nanoemulsões, com tamanho médio de gota variando entre 2 e $21 \mathrm{~nm}$, mostraram potencial antibacteriano para Escherichia coli. Entretanto, as nanoemulsões encapsulando capim limão, cravo, tomilho e palmarosa tiveram maior ação bactericida in vitro, com redução de 4,1, 3,6, 2,8 e 3,9 ciclos log, respectivamente, após 30 min de contato. Neste estudo, o potencial antimicrobiano das nanoemulsões foi associado ao tipo de OE utilizado na formulação e não ao tamanho de gota das nanoemulsões.

Nanoemulsões variando a concentração de $\mathrm{OE}$ de tomilho $(3-7 \% \mathrm{~m} / \mathrm{m})$ foram produzidas por Chang, McLandsborough e McClements (2015) utilizando a técnica de microfluidização. Entretanto, as nanoemulsões com concentrações superiores à $4 \%(\mathrm{~m} / \mathrm{m})$ não foram estáveis, e com isso, um tensoativo catiônico (arginato láurico) foi adicionado na formulação das nanoemulsões, permitindo que estas se tornassem estáveis em maiores concentrações do OE. As nanoemulsões encapsulando OE de tomilho mostraram-se eficiente para inibição de multiplicação da levedura Zygosaccharomyces bailii, sendo que, a adição do tensoativo arginato láurico nas nanoemulsões com $3 \%(\mathrm{~m} / \mathrm{m})$ de OE de tomilho foram eficientes em reduzir a CIM de 800 para $400 \mu \mathrm{g} / \mathrm{mL}$, indicando um efeito sinérgico entre os agentes antimicrobiano, OE de tomilho e o arginato láurico, na atividade antimicrobiana das nanoemulsões.

Estudos recentes têm avaliado as propriedades antimicrobianas das nanoemulsões encapsulando OEO com aplicação em matrizes alimentícias, evidenciando o potencial do OEO 
nanoemulsionado na preservação dos alimentos. Otoni et al. (2014) avaliaram as propriedades antimicrobianas de filmes comestíveis contendo nanoemulsões de OE de cravo da índia e de orégano com a finalidade de estender a vida de prateleira de pão fatiado. Os filmes comestíveis contendo as nanoemulsões, produzidas por homogeneizador ultrassônico, com 4 \% (m/v) de OEO reduziram a multiplicação de Aspergillus niger e Penicillium sp., em relação ao controle negativo (sem agente antimicrobiano) durante o período de 15 dias de armazenamento do pão fatiado.

Nanoemulsões encapsulando OEO também foram produzidas por Bhargava et al. (2015), que utilizaram homogeneização ultrassônica à alta pressão para produção destas nanoemulsões (com tamanho de gota de $148 \mathrm{~nm}$ ), variando a concentração de OEO $(0,05$ e 0,1 $\%$ v/v). A ação antibacteriana destas nanoemulsões foram avaliadas após a contaminação inicial da alface por Listeria monocytogenes, Salmonella typhimurium e Escherichia coli, a qual foi de 7,1, 6,9 e 6,3 log UFC/g, respectivamente. Após 72 horas de análise, as nanoemulsões com $0,05 \%$ (v/v) de OEO reduziram a multiplicação bacteriana para 3,44, 2,31 e 3,05 log UFC/g em L. monocytogenes, S. Typhimurium, e E. coli, respectivamente, enquanto que para as nanoemulsões com 0,1 \% (v/v) de OEO, esta redução foi de 3,57, 3,26 e 3,35 log UFC/g para as mesmas bactérias.

Revestimentos comestíveis contendo OEO nanoemulsionado aplicados em pedaços de queijo de baixo teor de gordura, com a finalidade de estender a vida de prateleira, foram estudados por Artiga-Artigas, Acevedo-Fani e Martín-Belloso (2017). As nanoemulsões, obtidas por microfluidização, foram produzidas variando a quantidade de OEO, 1,5, 2,0 e 2,5 $\%(\mathrm{~m} / \mathrm{m})$, sendo que estas concentrações afetaram significativamente a atividade antibacteriana para $S$. aureus. Após 15 dias da contaminação experimental do queijo por $S$. aureus (6 log UFC/g), foi observado uma redução de 1,4 e 1,5 log UFC/g nos pedaços de queijo contendo revestimento com $2 \%$ e $2,5 \%$ de OEO nanoemulsionado, respectivamente, entretando as nanoemulsões com 1,5\% de OEO não foram eficientes em reduzir a multiplicação bacteriana.

\subsection{Patê}

O patê, um produto com uma importante tradição gastronômica, é considerado um alimento que possui propriedades sensoriais interessantes e pode ser obtido a partir de diferentes tipos de carnes e ingredientes (AQUERRETA et al., 2002). Fabricado no mundo todo, o patê de frango, pode ser considerado um produto popular e de fácil acesso econômico (DELGADO- 
PANDO et al., 2011). Este produto alimentício é constituído por fígado, gordura e carne misturados com água e diferentes aditivos, o qual geralmente é embalado em recipientes de vidro e tratado termicamente (LORENZO; PATEIRO, 2013).

No Brasil, o regulamento técnico de identidade e qualidade de patê (BRASIL, 2000) define o patê como "um produto cárneo industrializado obtido a partir de carnes elou produtos cárneos elou miúdos comestíveis, das diferentes espécies de animais, os quais são transformados em pasta, adicionado de ingredientes e submetido a um processo térmico adequado". Os patês, seguidos de sua designação, deverão conter no mínimo $30 \%$ da matériaprima que o designe, exceto o de fígado cujo limite mínimo poderá ser de $20 \%$, e na sua composição apresenta como ingredientes obrigatórios carne e/ou miúdos específicos das espécies de animais, assim como sal, nitrito e/ou nitrato de sódio e/ou potássio (BRASIL, 2000). Como ingredientes opcionais, o patê pode conter: gordura animal e/ou vegetal, proteínas de origem animal e/ou vegetal, açúcares, maltodextrinas, leite em pó, amido, aditivos intencionais, vinho, conhaque, condimentos, aromas, especiarias, vegetais (como amêndoas, pistaches, frutas, trufas, azeitona) e queijos (BRASIL, 2000).

\subsection{Fatores que afetam a qualidade de produtos cárneos durante a vida de prateleira}

A presença de micro-organismos, a oxidação lipídica e a cor são importantes fatores que afetam a vida de prateleira do alimento cárneo (LORENZO et al., 2014a). Além de ser um produto altamente oxidável, o patê possui uma curta vida de prateleira após aberto (em média somente 4 dias), pois apesar de ser tratado termicamente, pode ser contaminado por bactérias pós-tratamento. A vida de prateleira muito curta é devida, portanto, aos efeitos da presença de oxigênio como também à enventuais contaminações microbianas relacionada à manipulação inadequada do produto (durante o processamento ou no consumo).

\subsubsection{Multiplicação bacteriana em produtos cárneos}

A presença de bactérias nos alimentos além de reduzir a vida de prateleira dos produtos cárneos também possibilita a veiculação de micro-organismos patogênicos, acarretando potenciais riscos à saúde do consumidor (CARVALHO et al., 2005). Em relação aos produtos cárneos derivados de frango, as aves encaminhadas para o abate normalmente são a fonte inicial de contaminação, e o número de micro-organismos presentes nas aves pode ser influenciado 
pelas condições higiênicas de abate e processamento (CARVALHO et al., 2005). A manipulação dos alimentos com baixo padrão higiênico-sanitário permite a multiplicação bacteriana e o desenvolvimento de bactérias patogênicas como a Escherichia coli (indicador de contaminação microbiana de origem fecal) e o Staphylococcus aureus (indicador de contaminação pós-processo ou das condições higiênico-sanitárias das superfícies que entram em contato com alimentos) (FRANCO; MANTILHA; LEITE, 2008; SILVA; JUNQUEIRA; SILVEIRA, 2002). De acordo com Oliveira et al. (2003), estas duas bactérias são também responsáveis por surtos de toxinfecção alimentar quando associados às condições higiênicosanitárias insatisfatórias dos manipuladores e utensílios.

Portanto, de acordo com a legislação brasileira (Brasil, 2000) as matérias-primas (carnes cruas, miúdos comestíveis e gorduras), assim como o produto elaborado (patê) devem ser manipulados, armazenados e transportados em locais próprios de forma que não fiquem expostos à contaminação ou sofram adição de qualquer substância nociva para o consumo humano.

O OEO já foi testado em alguns estudos visando aumentar a vida de prateleira de carne de frango fresca. Chouliara et al. (2007), avaliaram a carne de frango refrigerada sob as seguintes condições: controle (sem adição de OEO e sem atmosfera modificada), adição de OEO $(0,1 \%$ e $1 \% \mathrm{~m} / \mathrm{m})$, embalagem com atmosfera modificada e combinação da adição de $0,1 \%$ de OEO com atmosfera modificada. As amostras com $1 \%$ de OEO não obtiveram aceitação sensorial, por isso este tratamento não foi avaliado quanto à vida de prateleira. Os experimentos indicaram que a amostra controle apresentou vida de prateleira de 5 dias, na amostra adicionada de $0,1 \%$ de OEO este período foi de 8-9 dias, enquanto que para o tratamento com embalagem em atmosfera modificada apresentou vida de prateleira de 7-8 dias. A combinação de ambos $(0,1 \%$ de OEO e embalagem com atmosfera modificada) levou a um aumento da vida de prateleira para 10-11 dias, o que significou um prolongamento de $100 \%$ na vida de prateleira em relação ao controle.

Por sua vez, Oral et al. (2009) estudaram o efeito da adição de OEO nos "pads" absorventes de embalagens de carne de frango fresca, e observaram que houve um aumento de dois dias na vida de prateleira do alimento. O OEO foi eficiente na redução do número de microorganismos viáveis totais, bactérias psicrotróficas, Pseudomonas ssp., enterobactérias, leveduras e bactérias láticas. 
Khanjari, Karabagias e Kontominas (2013) avaliaram o efeito da adição de OEO (1 \% $(\mathrm{v} / \mathrm{v})$ em conjunto com a quitosana $(1 \% \mathrm{~m} / \mathrm{v})$ na vida de prateleira de filés de peito de frango in natura. Após a contaminação da carne de frango com baixa $\left(10^{3} \mathrm{UFC} \cdot \mathrm{g}^{-1}\right)$ e alta $\left(10^{5} \mathrm{UFC}_{\mathrm{g}} \mathrm{g}^{-1}\right)$ concentração do inóculo de Listeria monocytogenes, os autores concluíram que a combinação de ambas as substâncias foi eficiente em inibir completamente a multiplicação desta bactéria após 2 e 4 dias de armazenamento nas amostras de carne com baixa e alta contaminação, respectivamente. Além disso, foi possível observar uma extensão de 6 dias na vida de prateleira do filé de frango.

Pavelková et al. (2014) avaliaram o efeito da adição de OEO (0,2 \% v/p) em filés de peito de frango embalados a vácuo, sob temperatura de $4 \pm 0,5^{\circ} \mathrm{C}$, por 18 dias e verificou que houve uma redução significativa na contagem de micro-organismos viáveis totais, Pseudomonas aeruginosa e Lactobacillus sp. em comparação com a amostra controle (sem adição de OEO e sem embalagem a vácuo). Baseado nas análises microbiológicas, este estudo concluiu que os óleos essenciais podem estender a vida de prateleira de carnes e produtos cárneos, pois o tratamento com OEO prolongou a vida de prateleira da carne de frango de $8 \mathrm{a}$ 9 dias em comparação com a amostra controle.

\subsubsection{Processos oxidativos em produtos cárneos}

Os processos oxidativos em carne de frango e produtos cárneos derivados são intensos, devido à porcentagem de gordura insaturada presente nestes produtos e durante o armazenamento, esta oxidação pode acarretar na degradação dos pigmentos, dos lipídios e das proteínas, deteriorando o sabor, a textura, a cor e valor nutricional dos produtos (RODRÍGUEZCARPENA; MORCUENDE; ESTÉVEZ, 2011). Mudança de cor é um fator importante que influencia na qualidade e na aceitabilidade da carne e seus derivados (LORENZO et al., 2014a).

A oxidação lipídica afeta as propriedades sensoriais, devido ao desenvolvimento de offflavors e a produção de compostos potencialmente tóxicos, tais como peróxidos de ácidos graxos, hidroperóxido, e radicais peroxil (JAKOBSEN; BERTELSEN, 2000). Oxidação de duplas ligações instáveis em ácidos graxos poliinsaturados produz compostos oxidantes secundários, tais como hexanal, pentanal, heptanal e octanal que são responsáveis pela deterioração da qualidade e representam riscos para a saúde, incluindo a carcinogênese (ARABSHAHI-D; DEVI; UROOJ, 2007; GRÜN et al., 2006). 
Produtos de oxidação lipídica primários e secundários podem promover a degradação oxidativa de proteínas, sendo que os lipídios oxidados desempenham um papel significativo a este respeito (GARDNER, 1979; ESTÉVEZ et al., 2008). Os radicais peroxilados formados durante a oxidação lipídica podem remover átomos de hidrogênio das moléculas de proteína, levando a uma reação em cadeia semelhante à oxidação lipídica (STADTMAN; LEVINE, 2003). Por isso, a ocorrência e as consequências da oxidação de proteínas em produtos cárneos são questões de interesse crescente entre pesquisadores, uma vez que estudos recentes relatam a oxidação de proteínas com alterações nas estruturas da carne refrigerada (ESTÉVEZ et al., 2008).

O patê é um produto cárneo altamente suscetível à oxidação devido à sua composição química e aos processamentos aplicados no produto durante a produção, como trituração e tratamento térmico (ESTÉVEZ et al., 2007). Os produtos cárneos cozidos como o patê são mais suscetíveis à oxidação em relação à carne fresca devido à interação facilitada entre os ácidos graxos livres e o oxigênio na presença de catalisadores, tais como calor e metaloproteínas (MORRISSEY et al., 1998). A composição do patê de frango também interfere na oxidação do produto, pois além dos lipídios, o fígado de frango também exerce uma influência nos processos oxidativos, uma vez que apresenta elevada concentração de mioglobina e durante o tratamento térmico, ocorre a liberação de íons de ferro da mioglobina, os quais que são responsáveis por catalisar a oxidação lipídica (DELGADO-PANDO et al., 2012).

Por isso, a utilização de antioxidantes se torna uma das principais estratégias para prevenir oxidação e pode ser eficaz no controle e na redução da oxidação nos produtos à base de carne (LORENZO et al., 2014a). Porém, os antioxidantes mais utilizados nos alimentos, como BHT (hidroxitolueno butilado), BHA (hidroxianisol butilado), PG (propil galato), TBHQ (Butil hidroquinona terciária) constituem um perigo potencial para a saúde para os consumidores, e por esta razão, há um crescente interesse em estudos de aditivos naturais como potenciais antioxidantes (MOURE et al., 2001; KULISIC et al., 2004).

As propriedades antioxidantes de muitas plantas aromáticas e especiarias, como o OEO demonstraram ser eficazes no retardamento do processo de peroxidação lipídica de alimentos com elevado teor de gordura e ganharam o interesse de muitos grupos de pesquisa (KULISIC et al., 2004).

Em Sánchez-Escalante et al. (2003) o OEO aplicado em carne picada, nas concentrações de 0,02 e $0,1 \%(\mathrm{~m} / \mathrm{v})$, foi altamente eficaz na inibição da oxidação lipídica (formação de 
TBARS) em relação ao tratamento controle (sem antioxidantes). Após 24 dias de armazenamento das amostras sob refrigeração, o tratamento controle apresentou aproximadamente $4 \mathrm{mg}$ malonaldeído/kg, enquanto os tratamentos com 0,02 e 0,1\% de OEO, obtiveram aproximadamente 2,8 e 1,6 mg malonaldeído/kg, respectivamente.

Um estudo realizado por Tanabe, Yoshida e Tomita (2002) verificou a atividade antioxidante de amostras homogeineizadas de carne suína, com incorporação de 0,5 a 2,5\% $(\mathrm{m} / \mathrm{m})$ OEO, e indicou que houve uma redução de 58 \% na oxidação lipídica do produto cárneo. Fasseas et al. (2008) também avaliaram a atividade antioxidante de carne suína e bovina após a adição de $3 \%(\mathrm{~m} / \mathrm{m})$ de $\mathrm{OEO}$ e os resultados mostraram que houve uma redução significativa na oxidação lipídica para ambos tipos de carne.

\subsubsection{Métodos para determinação de oxidação lipídica em produtos cárneos}

A oxidação lipídica de produtos cárneos pode ser avaliada pelo índice de peróxidos e medições de TBARS, que permitem avaliar a oxidação lipídica primária e secundária, respectivamente (PATEIRO et al., 2014).

O índice de peróxido é um parâmetro importante a ser considerado na análise oxidativa dos produtos alimentares, uma vez que os peróxidos, chamados produtos de oxidação primária, são usados como indicadores de qualidade pois estão relacionados com a rancidez oxidativa nos alimentos (ARMENTA; GARRIGUES, DE LA GUARDIA, 2007). O método para determinação do valor de índice de peróxido é realizado por titulação iodométrica, a qual quantifica o iodo liberado da oxidação do iodeto de potássio, pelos peróxidos formados na oxidação lipídica, e tal índice é expresso como miliquivalentes de $\mathrm{O}_{2}$ por $\mathrm{kg}$ de amostra (ARMENTA; GARRIGUES, DE LA GUARDIA, 2007).

O ensaio de substâncias reativas ao ácido tiobarbitúrico (TBARS) foi proposto há mais de $40 \operatorname{anos}$ e, atualmente, é o método mais utilizado para detectar oxidação de lipídios (JARDINE et al., 2002). Nesta análise, o malonaldeído (MA), que é formado como resultado da oxidação lipídica, reage com ácido 2-tiobarbitúrico (TBA) para formar um pigmento cor-derosa que tem um máximo de absorção a 532-535 nm (JARDINE et al., 2002). Nesta reação (Figura 11), uma molécula de malonaldeído é condensada com 2 moléculas de ácido 2tiobarbitúrico sob aquecimento e em meio ácido (MOON; SHIBAMOTO, 2009). 
Figura 11. Reação entre malonaldeído (MA) e ácido 2- tiobarbitúrico que ocorre durante a análise de TBARS originando um composto de coloração rosa.

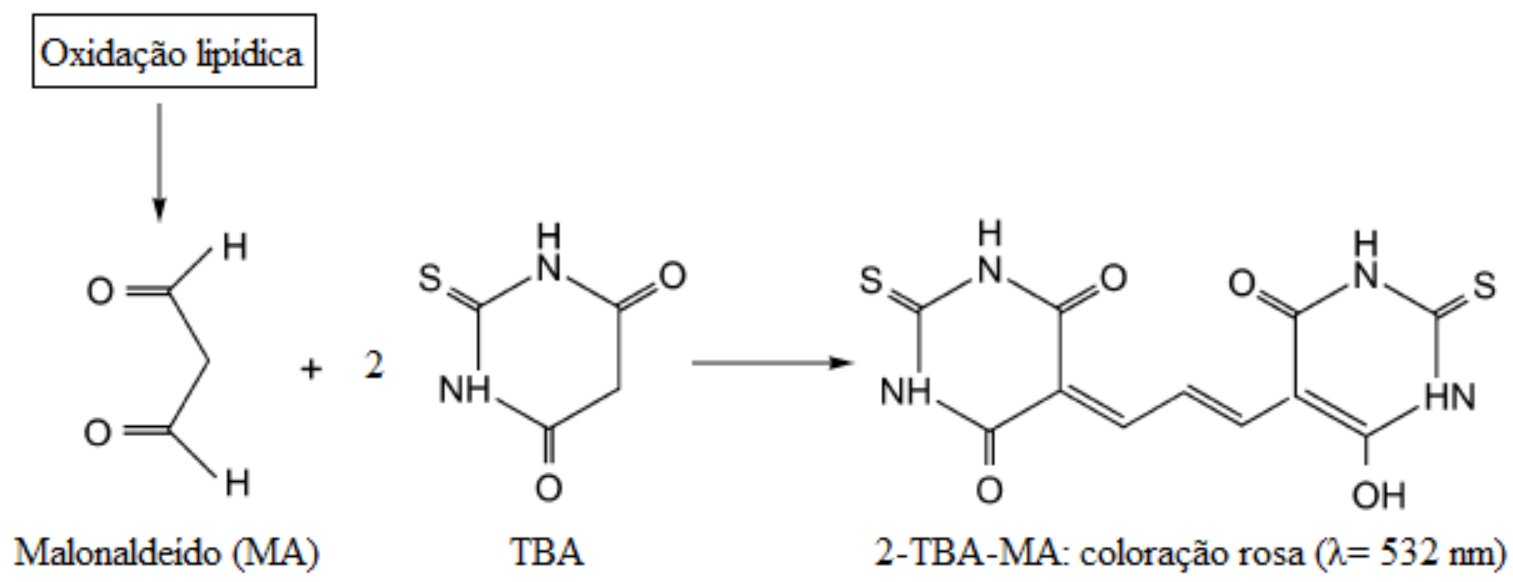

Fonte: Adaptado de Moon e Shibamoto (2009).

Entretanto, a presença de nitrito em produtos curados, como o patê, pode acarretar na determinação inadequada da oxidação lipídica de tais produtos pelo teste de TBARS, uma vez que a reação do nitrito com o ácido 2- tiobarbitúrico e o malonaldeído levam à uma superestimação dos valores obtidos nesta análise e para eliminar a interferência do nitrito, adiciona-se sulfanilamida para reagir com tal composto (IZUMIMOTO; ONYANGO; DARMADJI, 1997).

Frente às problemáticas de contaminação microbiológica e de oxidação de produtos cárneos apresentadas anteriormente, o desenvolvimento deste trabalho visou o estudo da encapsulação do OEO em nanoemulsões com a finalidade de avaliar se as nanoemulsões seriam eficientes em preservar a atividade antibacteriana e antioxidante do OEO. Além disso, verificou-se a possibilidade da utilização destas nanoemulsões como substitutintes de aditivos e conservantes sintéticos, avaliando o potencial antibacteriano e antioxidante das nanoemulsões quando aplicadas no patê de frango, bem como a análise da influência do OEO nanoemulsionado nas propriedades sensoriais deste alimento. 


\section{OBJETIVOS}

\subsection{Objetivos gerais}

Esta Tese teve como principais objetivos a produção, caracterização e avaliação da estabilidade físico-química de nanoemulsões encapsulando OEO, bem como a avaliação das atividades antimicrobiana e antioxidante (in vitro e em produto cárneo).

\subsection{Objetivos específicos}

- Determinar a temperatura de inversão de fases do sistema contendo óleo de girassol/OEO/água e tensoativos, com a finalidade de estabelecer a temperatura de aquecimento empregada durante a produção do sistema nanoemulsionado pelo método PIT;

- Avaliar a estabilidade físico-química das nanoemulsões encapsulando OEO pela determinação do tamanho do diâmetro hidrodinâmico médio das gotas, índice de polidispersidade e turbidez;

- Quantificar os compostos voláteis (timol, carvacrol e $\gamma$-terpineno) durante o período de armazenamento das nanoemulsões encapsulando OEO;

- Avaliar a atividade antibacteriana (para S. aureus e E. coli) e antioxidante das nanoemulsões in vitro e no patê de frango durante o armazenamento;

- Analisar a influencia da adição das nanoemulsões encapsulando OEO nas características organolépticas, como cor, aroma e sabor, do patê de frango; 


\section{MATERIAIS E MÉTODOS}

O fluxograma mostrado na Figura 12 descreve as etapas que foram desenvolvidas nesta Tese de Doutorado, e que serão descritas na seção 4.2:

Figura 12. Fluxograma das etapas experimentais realizadas durante a Tese.

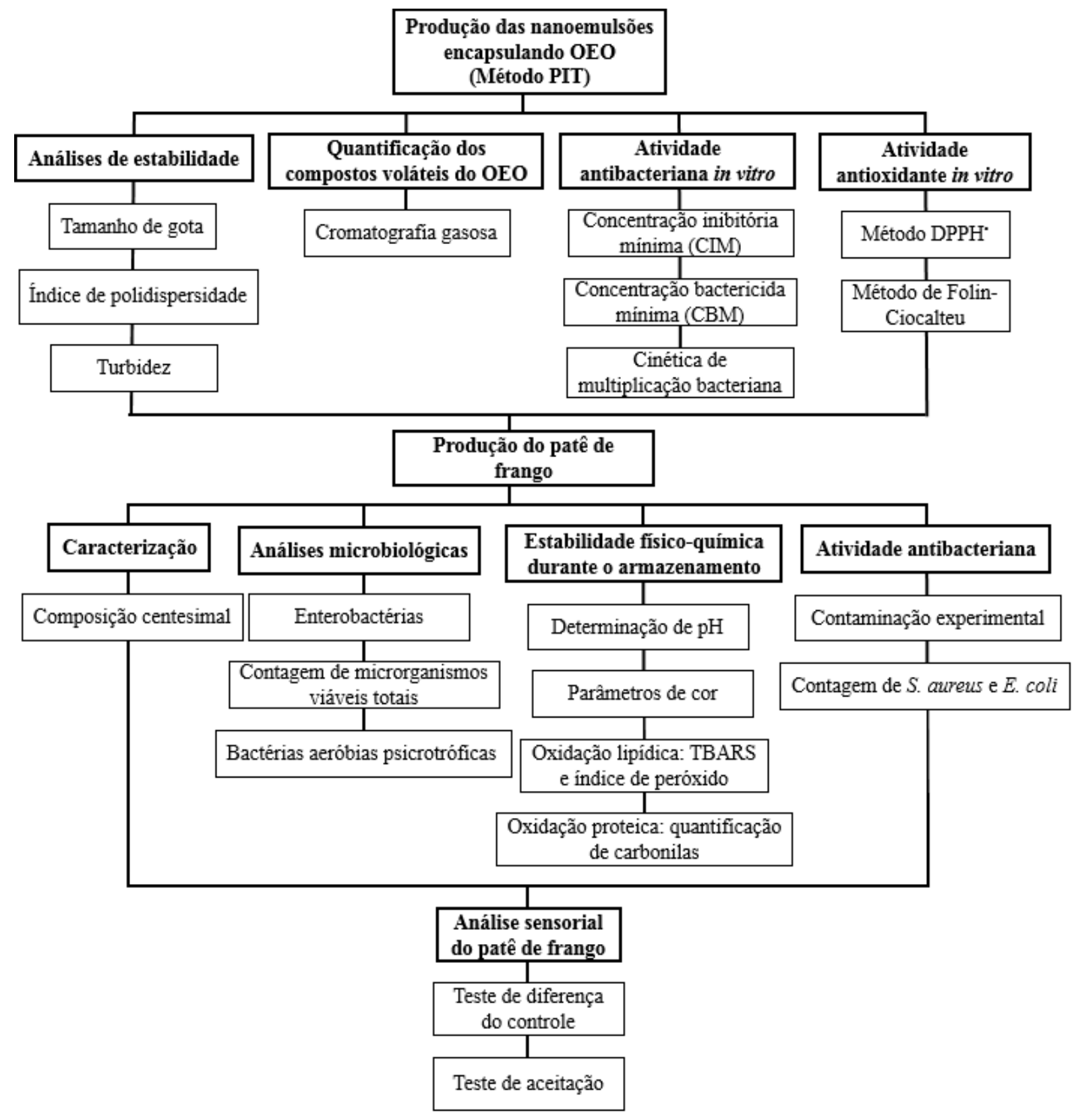

Fonte: Própria autoria. 


\subsection{MATERIAIS}

\subsubsection{Produção das nanoemulsões}

As nanoemulsões foram produzidas utilizando OEO (Origanum vulgare), obtido por destilação a vapor das folhas da planta (adquirido da Ferquima, Cotia, SP, Brasil) e óleo de girassol (Liza, Cargill, Mairinque, SP, Brasil). Os tensoativos não-iônicos empregados (cujas estruturas químicas estão descritas na Figura 13) foram: o óleo de mamona hidroxilado 40PEG (Cremophor RH40, BASF, Ludwigshafen, Alemanha ou Kolliphor RH40, Sigma- Aldrich, St. Louis, MO, EUA, equivalentes em composição química), o dodecil éter de polioetilenoglicol (Brij30, Sigma-Aldrich, St. Louis, MO, EUA), e o éster de sorbitan 80 (Span 80, SigmaAldrich, St. Louis, MO, EUA). Utilizou-se água deionizada obtida de um sistema Direct Q3 (Millipore, Billerica, MA, EUA).

Figura 13. Estrutura química dos tensoativos utilizados na formulação das nanoemulsões encapsulando óleo essencial de orégano.

Cremophor RH40

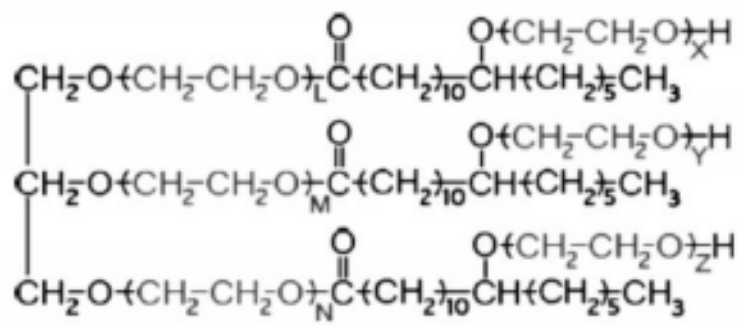

$(\mathrm{L}+\mathrm{M}+\mathrm{N}+\mathrm{X}+\mathrm{Y}+\mathrm{Z}=40)$

Brij 30

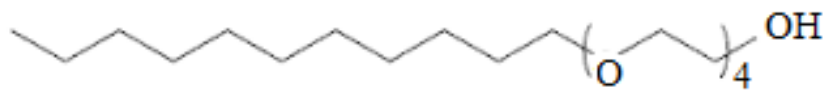

$$
\mathrm{C}_{20} \mathrm{H}_{42} \mathrm{O}_{5}
$$

Span 80

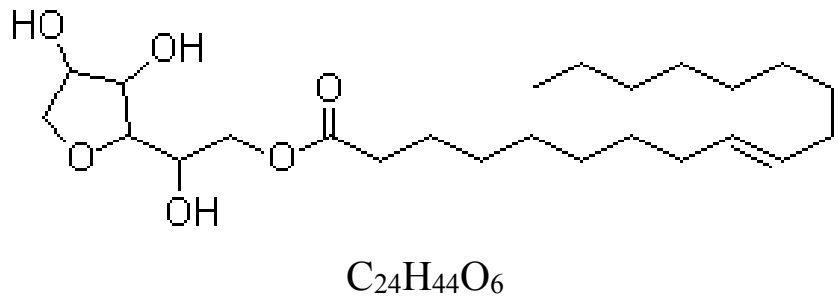

Fonte: Adaptado de Sigma-Aldrich (2017). 


\subsubsection{Quantificação dos componentes presentes no óleo essencial de orégano encapsulado}

Na quantificação do OEO nanoemulsionado foram utilizados os compostos-padrão: timol (pureza $\geq 99,5 \%$ ), carvacrol (pureza 98,0 \%) e $\gamma$-terpineno (pureza $\geq 97,0 \%$ ) todos obtidos da Sigma-Aldrich (St. Louis, MO, EUA) e o solvente empregado foi o acetato de etila p.a. (Synth, Diadema, SP, Brasil). Para desestabilizar o sistema nanoemulsionado na quantificação dos compostos, foi utilizado etanol absoluto p.a. (Merck, Darmstadt, Alemanha).

\subsubsection{Análises de atividade antibacteriana in vitro das nanoemulsões}

$\mathrm{Na}$ determinação da concentração inibitória mínima (CIM), foram utilizados caldo nutriente (Acumedia, Lansing, MI, EUA), caldo BHI (Brain Heart Infusion, Acumedia, Lansing, MI, EUA), antibiótico cloranfenicol (Farmácia Ouro Preto, Pirassununga, SP, Brasil), corante cloreto iodonitrotetrazólio (Sigma-Aldrich, St. Louis, MO, EUA) e água deionizada (Millipore, Billerica, MA, EUA) esterilizada. Para análise da CBM foram empegadas placas de Petri esterilizadas (J. Prolab, São José dos Pinhais, PR, Brasil) e ágar nutriente (Acumedia, Lansing, MI, EUA).

Para determinação da cinética de multiplicação bacteriana foram utilizados caldo BHI (Brain Heart Infusion) e ágar nutriente (Acumedia, Lansing, MI, EUA), água peptonada estéril $0,1 \% \mathrm{~m} / \mathrm{v}$ (Merck, Darmstadt, Alemanha), água deionizada (Millipore, Billerica, MA, EUA) esterilizada e placas de Petri esterilizadas (J. Prolab, São José dos Pinhais, PR, Brasil).

Em todos os experimentos foram empregadas cepas-padrão das seguintes bactérias: Staphylococcus aureus (ATCC 25923) e Escherichia coli (ATCC 25922).

\subsubsection{Atividade antioxidante das nanoemulsões in vitro}

Nas análises de porcentagem de redução dos radicais DPPH foram utilizados 2,2difenil-1-picrilhidrazila (DPPH, Sigma-Aldrich, St. Louis, MO, EUA), etanol anidro (pureza 99,5\%) e metanol, ambos obtidos da Dinâmica (Diadema, SP, Brasil). Para a quantificação do teor de fenólicos totais, foram empregados o reagente Folin-Ciocalteu (Imbralab, Ribeirão Preto, SP, Brasil), ácido gálico (Acros Organics, New Jersey, NJ, EUA), carbonato de sódio (Synth, Diadema, SP, Brasil) e água deionizada obtida de um sistema Direct Q3 (Millipore, Billerica, MA, EUA). 


\subsubsection{Produção do patê de frango}

Para a produção do patê de frango foram utilizados gordura abdominal, filé de peito e fígado de frango, os quais foram obtidos em abatedouro (Avícola Finardi, Araras, SP, Brasil). Também foram utilizados margarina sem sal, sal refinado, maltodextrina (MOR-REX® 1920, Ingredion, Mogi-Guaçu, SP, Brasil), goma xantana (Grindsted 80®, Du Pont, Cotia, SP, Brasil), cebola desidratada e alho desidratado. O BHT, nitrito de sódio e ácido lático foram obtidos da Synth (Diadema, SP, Brasil).

\subsubsection{Análises microbiológicas no patê de frango: determinação da vida de prateleira e determinação da qualidade microbiológica para análise sensorial}

Nas análises microbiológicas realizadas no patê de frango, foram utilizados água peptonada estéril 0,1\% m/v, ágar padrão para contagem (PCA) e ágar VRBG (Violet Red Bile Glucose), todos obtidos da Merck (Darmstadt, Alemanha), e placas de Petri esterilizada (J. Prolab, São José dos Pinhais, PR, Brasil).

\subsubsection{Atividade antibacteriana das nanoemulsões no patê de frango}

Para a contaminação experimental do patê de frango, foram empregadas as cepas-padrão de Staphylococcus aureus (ATCC 25923) e Escherichia coli (ATCC 25922). O meio utilizado para a multiplicação das bactérias foi o BHI (Brain Heart Infusion, Acumedia, Lansing, MI, EUA), para a contagem de S. aureus foi utilizado Petrifilm ${ }^{\mathrm{TM}}$ Staph Express (3M Microbiology Products, St. Paul, MN, EUA) e para a E. coli, placas de Petri com ágar E. coli cromogênico (Laborclin, Pinhais, PR, Brasil).

\subsubsection{Atividade antioxidante das nanoemulsões no patê de frango}

$\mathrm{Na}$ determinação do índice de peróxido foram empregados sulfato de sódio anidro (Synth, Diadema, SP, Brasil), ácido acético, iodeto de potássio, tiossulfato de sódio, dicromato de potássio, ácido clorídrico, amido solúvel p.a., clorofórmio e metanol, obtidos da Dinâmica (Diadema, SP, Brasil). 
Para quantificação de TBARS, foram utilizados ácido tricloroacético (Dinâmica, Diadema, SP, Brasil), ácido tiobarbitúrico (J.T. Baker® Chemical Co., Phillipsburg, NJ, EUA), 1,1-3,3 tetraetoxihipropano (Sigma-Aldrich, St. Louis, MO, EUA) e sulfanilamida (Dinâmica, Diadema, SP, Brasil).

Para quantificação de carbonilas totais, foram utilizados cloreto de potássio (Synth, Diadema, SP, Brasil), ácido tricloroacético (TCA), ácido clorídrico (pureza 36,5 - 38\%) 2,4dinitrofenil-hidrazina (DNPH), acetato de etila e etanol anidro (pureza 99,5\%), obtidos da Dinâmica (Diadema, SP, Brasil), fosfato de sódio monobásico e fosfato de sódio dibásico obtidos da Synth (Diadema, SP, Brasil), guanidina HCl (Sigma-Aldrich, St. Louis, MO, EUA) e albumina de soro bovino (BSA, Sigma-Aldrich, St. Louis, MO, EUA).

\subsubsection{Análise sensorial}

Para a análise sensorial foram empregadas bandejas para servir as amostras, guardanapos, copo com água, bolachas do tipo água e sal, torradas e também os brindes oferecidos aos provadores: amendoim, bombom e picolé.

\subsection{MÉTODOS}

\subsubsection{Produção das nanoemulsões encapsulando óleo essencial de orégano pelo método da temperatura de inversão de fases (PIT - phase inversion temperature)}

O método empregado na produção das nanoemulsões foi o método PIT (phase inversion temperature, ou temperatura de inversão de fases), que foi realizado segundo Gomes et al. (2017). Em um béquer foram adicionados os tensoativos, o OEO, o óleo de girassol e a água deionizada, de modo a produzir as formulações descritas na Tabela 3. Em seguida, os componentes da mistura foram submetidos à agitação magnética (MA085, Marconi, Piracicaba, SP, Brasil) a $1350 \mathrm{rpm}$, utilizando-se aquecimento em banho de areia até uma temperatura de aproximadamente $65^{\circ} \mathrm{C}$. Após este aquecimento, as formulações foram resfriadas até aproximadamente $20^{\circ} \mathrm{C}$ em um béquer encamisado (sob agitação magnética de $585 \mathrm{rpm}$ ), acoplado em um banho ultratermostatizado (MA184, Marconi, Piracicaba, SP, Brasil) com água 
de resfriamento a $0^{\circ} \mathrm{C}$. As amostras foram submetidas a dois ciclos de aquecimento e resfriamento.

Tabela 3. Descrição das formulações $(\% \mathrm{~m} / \mathrm{m})$ das nanoemulsões encapsulando óleo essencial de orégano produzidas pelo método de temperatura de inversão de fases.

\begin{tabular}{|c|c|c|c|}
\hline Nanoemulsões & Tensoativos & Fase oleosa & $\begin{array}{c}\text { Fase contínua } \\
\text { (água deionizada) }\end{array}$ \\
\hline NA-3,25 & $\begin{array}{c}\text { Cremophor RH } 40(9,75 \%) \\
\text { Brij } 30(3,25)\end{array}$ & $\begin{array}{l}\text { Óleo de girassol }(3,25 \%) \\
\text { Óleo essencial de orégano } \\
\qquad(3,25 \%)\end{array}$ & $80,5 \%$ \\
\hline NA-5 & $\begin{array}{c}\text { Cremophor RH } 40(12 \%) \\
\text { Span } 80(8 \%)\end{array}$ & $\begin{array}{c}\text { Óleo de girassol (5\%) } \\
\text { Óleo essencial de orégano } \\
(5 \%)\end{array}$ & $70 \%$ \\
\hline
\end{tabular}

Fonte: Própria autoria.

\subsubsection{Determinação da temperatura de inversão de fases das nanoemulsões}

A temperatura de transição de fases (temperatura PIT) foi determinada pelo cálculo da média entre a temperatura de início da queda da condutividade e a temperatura final, após a inversão de fase de óleo em água para água em óleo. A condutividade das amostras foi medida utilizando-se um condutivímetro Inolab 740 com uma célula Tetracon 325 (WTW, Weilheim, Alemanha).

\subsubsection{Determinação de diâmetro médio de gota, polidispersidade e distribuição de tamnho} de gota.

As medidas de tamanho de gota, da polidispersidade e da distribuição do tamanho de gota das nanoemulsões foram realizadas por espalhamento de luz quasi-elástico em equipamento ZetaPlus (Brookhaven Instruments Company, Holtsville, NY, EUA). O laser empregado foi de He-Ne com comprimento de onda de $627 \mathrm{~nm}$, com ângulo de incidência de $90^{\circ}$ e na temperatura de $25^{\circ} \mathrm{C}$. Antes da análise as amostras foram diluídas com água deionizada para evitar o espalhamento múltiplo de luz. As análises de dados foram realizadas pelo software incluso no sistema (90Plus). 


\subsubsection{Determinação da turbidez das nanoemulsões}

As análises de turbidez foram realizadas, em triplicata, convertendo as medidas de absorbâncias obtidas no espectrofotômetro (Libra S22, Biochrom, Cambridge, Reino Unido) no comprimento de onda de $600 \mathrm{~nm}$. A turbidez $(\tau)$ das amostras de nanoemulsões foi obtida de acordo com Eq. (4) e (5) (McCLEMENTS, 2004):

$$
\begin{aligned}
& A=\log _{10}\left(\frac{1}{T}\right) \\
& \tau=\frac{-\ln (T)}{1}
\end{aligned}
$$

sendo:

$\mathrm{A}=$ absorbância das amostras de nanoemulsões em $600 \mathrm{~nm}$

$\mathrm{T}=$ transmitância

$\tau=$ turbidez das nanoemulsões

\subsubsection{Quantificação dos compostos encapsulados por cromatografia gasosa}

Para o monitoramento da perda dos compostos voláteis durante 60 dias de armazenamento das nanoemulsões, foram feitas as quantificações dos compostos: carvacrol, timol e $\gamma$-terpineno. As análises foram realizadas por cromatografia gasosa na Divisão de Química de Produtos Naturais do Centro Pluridisciplinar de Pesquisas Químicas, Biológicas e Agrícolas (CPQBA/UNICAMP), com orientação do pesquisador Dr. Rodney A. F. Rodrigues. $\mathrm{Na}$ quantificação dos compostos encapsulados, foi necessário desestabilizar o sistema nanoemulsionado para extrair o OEO. Para isso, foram adicionados etanol nas formulações na razão formulação e etanol de 1:10.

Após preparar as diluições, as amostras foram injetadas no cromatógrafo gasoso (Hewlett- Packard 5890 Series II, Palo Alto, CA, EUA) com injetor automático HP 7673, e detector seletivo de massas HP 5975 (Agilent Technologies, Palo Alto, CA, EUA), por impacto de elétrons no modo de ionização $(70 \mathrm{eV})$. O cromatógrafo foi operado nas condições experimentais baseadas no protocolo de Sartoratto et al. (2004), as quais foram as seguintes: modo de injeção split (razão 1:40), coluna capilar HP-5 (25 m de comprimento x 0,2 mm de diâmetro interno x $0,33 \mu \mathrm{m}$ de espessura de filme) e hélio como gás de arraste na taxa de 1,0 
mL.min-1. A temperatura empregada no detector foi $250^{\circ} \mathrm{C}$, no injetor de $220^{\circ} \mathrm{C}$ e na coluna, de 60 a $240^{\circ} \mathrm{C} /\left(3^{\circ} \mathrm{C} / \mathrm{min}\right) / 7$ minutos. As análises foram realizadas em triplicata, com monitoramento dos íons, que representam os fragmentos principais dos três analitos: 77, 91, 93, $115,121,135,136$ e 150. Para cada dia de análise, a curva analítica dos compostos foi injetada.

As curvas analíticas foram preparadas para a quantificação dos seguintes componentes: carvacrol, timol e $\gamma$-terpineno, com concentração variando de 40 a $400 \mu \mathrm{g} / \mathrm{mL}$. A identificação dos constituintes voláteis das curvas analíticas foi realizada por comparação com os tempos de retenção dos padrões.

\subsubsection{Determinação da atividade antibacteriana in vitro das nanoemulsões}

A avaliação da atividade antimicrobiana in vitro das nanoemulsões foi realizada pela determinação da CIM, utilizando a técnica de macrodiluição de acordo com Souza et al. (2009). Para isso, foram adicionados em cada tubo de ensaio $2,5 \mathrm{~mL}$ de caldo nutriente, $0,5 \mathrm{~mL}$ do inóculo de Staphylococcus aureus ou Escherichia coli na concentração de 1-2 x $10^{8} \mathrm{UFC} / \mathrm{mL}$ (obtido das bactérias cultivadas em caldo $\mathrm{BHI}$ a $35^{\circ} \mathrm{C} / 24 \mathrm{~h}$ ) e $2 \mathrm{~mL}$ das concentrações de nanoemulsões diluídas em água deionizada esterilizada. Após esta etapa, os tubos foram agitados em vórtex (QL-901, Biomixer, São Paulo, SP, Brasil) por 30 segundos e incubados a $37^{\circ} \mathrm{C}$ por 24 horas. Então, $40 \mu \mathrm{L}$ de uma solução de corante cloreto iodonitrotetrazólio a 2 $\mathrm{mg} / \mathrm{mL}$ foram adicionados aos tubos de ensaio, e em seguida, agitados no vórtex por 30 segundo e incubados, novamente, a $37^{\circ} \mathrm{C}$ por mais 24 horas. Após este período, verificou-se a CIM pela diferença de coloração entre as concentrações. Os controles positivos e negativos foram realizados em todos os experimentos, nos quais, ao controle positivo, foi adicionado $2 \mathrm{~mL}$ de uma solução de cloranfenicol $1 \mathrm{mg} / \mathrm{mL}$ e ao negativo, foi adicionado $2 \mathrm{~mL}$ de água deionizada esterilizada.

A CBM foi determinada inserindo $100 \mu \mathrm{L}$ da mistura, contida nos tubos de ensaio com concentrações superiores a CIM, em placas de Petri com ágar nutriente (espalhando em forma de oito) e incubadas a $37^{\circ} \mathrm{C}$, por 24 horas. Após este período, a CBM foi determinada visivelmente pela ausência $\sim$ de colônias de bactérias Staphylococcus aureus e Escherichia coli nas placas. As análises para determinação de CIM e CBM foram realizadas em triplicata. 


\subsubsection{Cinética da multiplicação in vitro das bactérias}

Para obter a curva da multiplicação bacteriana, as misturas foram preparadas segundo Souza et al. (2009). Para isso, foram adicionados $5 \mathrm{ml}$ de caldo nutriente, $1 \mathrm{ml}$ do inóculo de Staphylococcus aureus ou Escherichia coli com concentração de aproximadamente $7 \log$ $\mathrm{UFC} / \mathrm{ml}$ (obtido das bactérias cultivadas em caldo BHI a $35^{\circ} \mathrm{C} / 24 \mathrm{~h}$ ), e $4 \mathrm{ml}$ das nanoemulsões na CIM. No controle negativo foram adicionados $4 \mathrm{ml}$ de água estéril e no controle positivo, 4 $\mathrm{ml}$ de solução cloranfenicol $1 \mathrm{mg} / \mathrm{ml}$. Estas misturas foram agitadas durante 30 segundos e incubadas a $37^{\circ} \mathrm{C}$. Após $0,24,48$ e 72 horas de incubação, foram realizadas diluições seriadas em água peptonada estéril $(0,1 \% \mathrm{~m} / \mathrm{v})$ e $100 \mu \mathrm{l}$ de cada diluição foi inoculada, em placas de Petri com ágar nutriente, a $37^{\circ} \mathrm{C}$. Após 24 horas, a contagem de bactérias foi realizada e os resultados foram expressos em $\log \mathrm{UFC} \cdot \mathrm{ml}^{-1}$.

\subsubsection{Atividade antioxidante in vitro do oléo essencial de orégano não-emulsionado}

O potencial antioxidante do OEO não-emulsionado foi determinado pelo valor de IC50, de acordo com Boroski et al. (2012) (com modificações). Inicialmente foram preparadas soluções metanólicas de OEO, com concentrações variando de 0,4 a $15 \mathrm{mg} / \mathrm{mL}$. Uma alíquota de $50 \mu \mathrm{L}$ e $1950 \mu \mathrm{L}$ de solução metanólica de $\mathrm{DPPH}^{\bullet} 6 \times 10^{-5} \mathrm{~mol} / \mathrm{L}$ foram misturadas e mantidas em ambiente escuro a $25^{\circ} \mathrm{C}$ por 1 hora. Após esse período foi realizada a leitura da absorbância a 517 nm em espectrofotômetro (DR-2800, Hach, Loveland, CO, EUA). Metanol foi utilizado para zerar o espectrofotômetro e as análises foram realizadas em triplicata. $\mathrm{O}$ valor de IC50, referente a redução de 50 \% dos radicais de $\mathrm{DPPH}^{\bullet}$, foi obtida graficamente pela curva padrão de concentração da solução metanólica de OEO $(\mathrm{mg} / \mathrm{mL})$ versus porcentagem de inibição.

\subsubsection{Atividade antioxidante in vitro do óleo essencial de orégano nanoemulsionado}

A avaliação da atividade antioxidante das nanoemulsões encapsulando OEO foi determinada pela capacidade de redução dos radicais $\mathrm{DPPH}^{\bullet}$ e pela quantificação de fenólicos totais. Estas análises foram executadas em triplicata durante o período de 24 semanas. 


\subsubsection{Porcentagem de redução dos radicais DPPH}

A capacidade de sequestro do radical $\mathrm{DPPH}^{\bullet}$ foi realizada de acordo com BrandWilliams, Cuvelier e Berset (1995) e Mahdi et al. (2011), com modificações. Uma alíquota de $20 \mu \mathrm{L}$ da amostra e $1980 \mu \mathrm{L}$ da solução etanólica de $\mathrm{DPPH}^{\bullet}(0.5 \mathrm{mM})$ foram agitadas em vórtex (QL-901, Biomixer, São Paulo, SP, Brasil) por $30 \mathrm{~s}$ e mantidas em ambiente escuro a $25^{\circ} \mathrm{C}$. Após $1 \mathrm{~h}$, a diminuição da absorbância a $517 \mathrm{~nm}$ foi determinada em espectrofotômetro (DR2800, Hach, Loveland, CO, EUA). Etanol foi utilizado para zerar o espectrofotômetro e todo o experimento foi realizado em triplicata. Os resultados foram expressos em \% de redução dos radicais $\mathrm{DPPH}^{\bullet}$ de acordo com a Eq. (6):

$$
\% \text { redução dos radicais } \mathrm{DPPH}^{\bullet}=\frac{\text { Abs controle }- \text { Abs amostra }}{\text { Abs controle }} \times 100
$$

sendo:

Abs controle: absorbância da amostra sem antioxidantes (solução etanólica DPPH + água deionizada)

Abs amostra: absorbância das amostras de nanomemulsões (solução etanólica DPPH + nanoemulsão)

\subsubsection{Teor de fenólicos totais}

A determinação de fenólicos totais foi realizada segundo Singleton, Orthofer e LamuelaRaventos (1999), com modificações. Inicialmente foi realizada a diluição das nanoemulsões em água deionizada, e em seguida, $250 \mu \mathrm{L}$ das amostras de nanoemulsões diluídas foram adicionadas a $2 \mathrm{~mL}$ de água deionizada e $250 \mu \mathrm{L}$ do reagente de Folin-Ciocalteu. Esta mistura foi agitada em vórtex (QL-901, Biomixer, São Paulo, SP, Brasil) por $30 \mathrm{~s}$, e após 3 min à temperatura ambiente, foram adicionados $250 \mu \mathrm{L}$ da solução saturada de carbonato de sódio e ocorreu nova agitação. As amostras foram colocadas em banho-maria (Marconi MA127, Piracicaba, SP, Brasil) a $37^{\circ} \mathrm{C}$ por $30 \mathrm{~min}$. A absorbância a $750 \mathrm{~nm}$ foi determinada em espectrofotômetro (Libra S22, Biochrom, Cambridge, Reino Unido) e o conteúdo de fenólicos totais foi calculado utilizando-se curva padrão de ácido gálico. Os resultados obtidos foram expressos como mg equivalente de ácido gálico/mL de amostra. 


\subsubsection{Produção e formulação do patê de frango}

As amostras de patê de frango foram produzidas na Planta Piloto de Processamento de Alimentos, na Faculdade de Zootecnia e Engenharia de Alimentos (FZEA/USP). No início do processo produtivo, a carne magra e o fígado foram picados em cubos pequenos e posteriormente, a carne foi submetida a um processo de escaldagem, a $65^{\circ} \mathrm{C}$ por $10 \mathrm{~min}$, e o fígado foi frito por aproximadamente $5 \mathrm{~min}$. A gordura foi triturada, peneirada e, posteriormente, aquecida por $5 \mathrm{~min}$. Após atingirem temperatura ambiente, estes produtos foram inseridos em um liquidificador, no qual foram adicionados os demais ingredientes e então, submetidos ao processo de homogeneização.

Para a formulação da base de patê, utilizou-se (\% mássicas): 40\% de carne magra de frango, $10 \%$ de fígado de frango, $10 \%$ de gordura subcutânea de frango, $21 \%$ de água fria filtrada, $10 \%$ de margarina, $5 \%$ de maltodextrina, $2 \%$ de sal cloreto de sódio, $1 \%$ de goma xantana, $0,8 \%$ de cebola desidratada e $0,2 \%$ de alho desidratado.

\subsubsection{Desenho experimental do processamento do patê de frango}

As etapas de produção do patê de frango são descritas no fluxograma da Figura 14. As amostras de patê de frango foram produzidas em triplicata. 
Figura 14. Fluxograma da produção do patê de frango e os tratamentos aplicados. *Quantidade determinada pela concentração inibitória mínima dos testes in vitro: 0,2\% $\%(\mathrm{~m} / \mathrm{m})$ para as nanoemulsões NA-3,25 e 0,06 \% (m/m) para as nanoemulsões NA-5. ${ }^{* *}$ Valores máximos de adição de BHT (100 mg/kg) e nitrito de sódio $(150 \mathrm{mg} / \mathrm{kg})$ permitidos pela legislação brasileira (BRASIL, 2007).

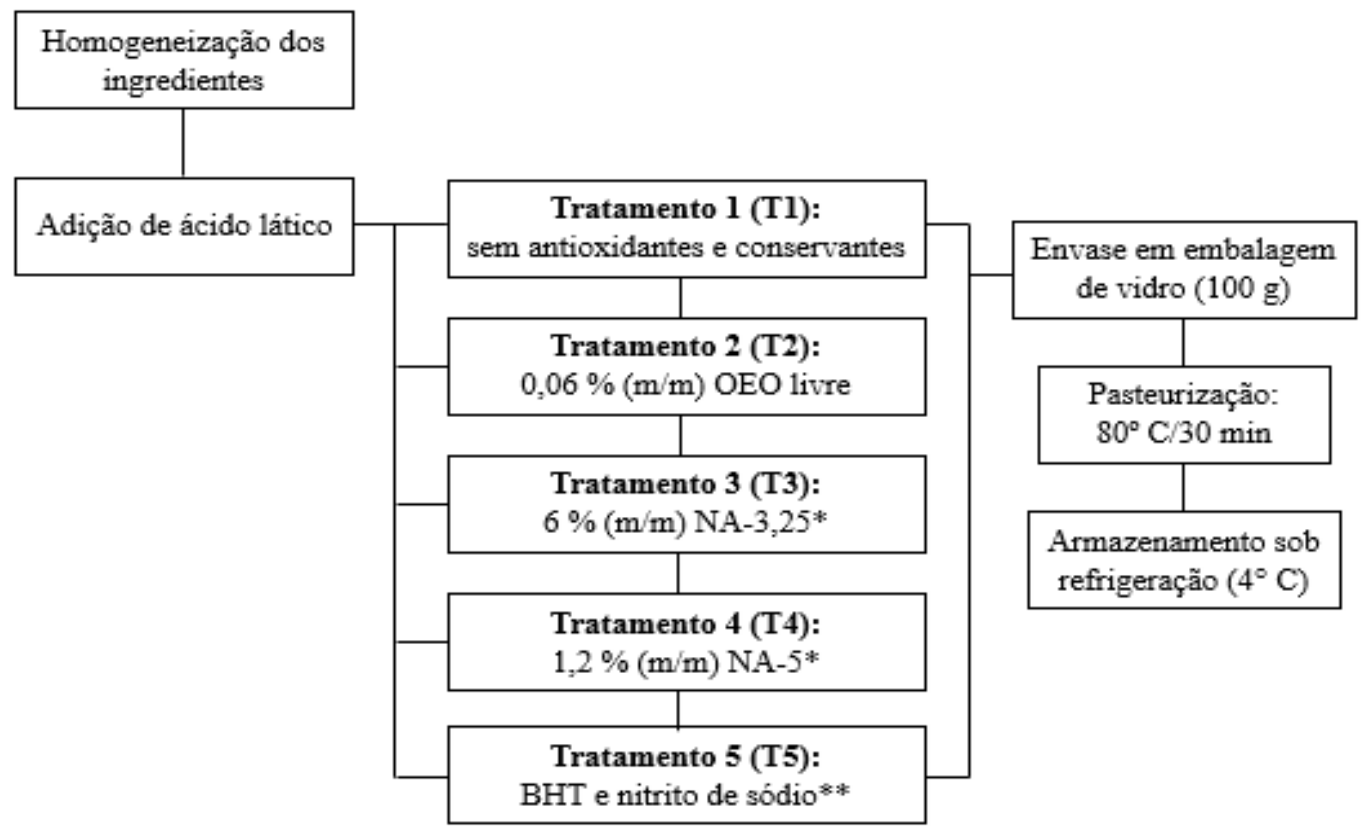

Fonte: Própria autoria.

\subsubsection{Determinação da composição centesimal do patê de frango}

A determinação da composição centesimal do produto foi realizada durante a primeira semana após a produção do patê de frango e as análises foram realizadas em duplicata. Os teores de umidade, proteína e cinzas foram determinados de acordo com os métodos analíticos oficiais AOAC (AOAC, 2000a; AOAC, 2000b; AOAC, 2000c). A quantificação de gordura foi realizada utilizando o método de Bligh e Dyer (1959).

\subsubsection{Análises microbiológicas do patê de frango durante $o$ armazenamento: Enterobactérias, contagem de micro-organismos viáveis totais e bactérias aeróbias psicrotróficas}

Estas análises foram realizadas com a finalidade de verificar a eficiência do tratamento térmico (pasteurização) e também determinar a vida de prateleira do patê de frango produzido. 
Os testes microbiológicos foram realizados, em triplicata, nas amostras de patê de frango refrigeradas (aproximadamente $4^{\circ} \mathrm{C}$ ), durante as semanas $0,4,8$ e 16 de armazenamento.

O protocolo de análise foi estabelecido de acordo com Silva et al. (2010), no qual, inicialmente, $25 \mathrm{~g}$ da amostra de patê de cada tratamento foram pesadas assepticamente, em seguida foram adicionados $225 \mathrm{~mL}$ de água peptonada estéril $0,1 \% \mathrm{~m} / \mathrm{v}$ (diluição $10^{-1}$ ) e homogeneizadas por aproximadamente $1 \mathrm{~min}$. Para cada amostra, foi realizada uma diluição $\left(10^{-2}\right)$ e em seguida foi feito o plaqueamento. O plaqueamento para realizar a contagem de micro-organismos viáveis totais e das bactérias aeróbias psicrotróficas foi realizado em superfície, no qual $0,1 \mathrm{~mL}$ das diluições foram espalhados em placas com ágar padrão para contagem (PCA), e incubadas a $35 \pm 1^{\circ} \mathrm{C}$ durante $48 \pm 2 \mathrm{~h}$ e a $7 \pm 1^{\circ} \mathrm{C}$ durante 10 dias, respectivamente. Para as enterobactérias foi realizado o plaqueamento por profundidade com sobrecamada no ágar VRBG (violet red bile glucose), seguida de incubação a $35 \pm 1^{\circ} \mathrm{C}$ por 24 horas.

\subsubsection{Atividade antibacteriana das nanoemulsões no patê de frango}

A avaliação da atividade antibacteriana para Staphylococcus aureus e Escherichia coli das nanoemulsões no patê de frango foi realizada após a contaminação experimental das amostras por estas bactérias. Segundo Oliveira et al. (2013), com algumas modificações, 5 amostras de cada tratamento contendo $10 \mathrm{~g}$ de patê de frango, foram pesadas assepticamente, e em seguida foram adicionados $2 \mathrm{~mL}$, em cada amostra, dos inóculos de Staphylococcus aureus e Escherichia coli, separadamente, em concentrações em torno de $10^{5}-10^{7} \mathrm{UFC} / \mathrm{mL}$ (obtidos das bactérias cultivadas em caldo BHI a $35^{\circ} \mathrm{C} / 24 \mathrm{~h}$ ). Em seguida, estas amostras foram armazenadas sob refrigeração a $4^{\circ} \mathrm{C}$, e após um período de $0,1,3,6$ e 8 dias foram realizadas a quantificação das bactérias.

Para quantificar as bactérias, inicialmente, foram adicionados $90 \mathrm{~mL}$ de solução peptonada estéril $0,1 \% \mathrm{~m} / \mathrm{v}$ nas amostras de $10 \mathrm{~g}$ de patê e homogeneizada por $1 \mathrm{~min}$, resultando na diluição $10^{-1}$. Em seguida, foram preparadas diluições seriadas decimais até $10^{-6}$ para Escherichia coli e até $10^{-2}$ para Staphylococcus aureus.

A contagem de Staphylococcus aureus nas amostras de patê foi realizada pelo Método Oficial AOAC 2003.07 (AOAC, 2006), no qual foram utilizados, como meio de cultura, as placas Petrifilm TM Staph Express e para a inoculação, as placas foram dispostas sobre superfícies planas, levantando-se o filme superior da placa, inserindo $1 \mathrm{~mL}$ da diluição das 
amostras e espalhando a amostra com um auxílio de um difusor. Posteriormente, as placas foram incubadas a $35 \pm 1^{\circ} \mathrm{C}$ por 24 horas. Para a Escherichia coli foram utilizadas, placas de Petri com ágar E. coli cromogênico nas quais $0,1 \mathrm{~mL}$ das diluições foram inseridas nas placas e após espalhar sobre as placas, estas foram incubadas a $35 \pm 1^{\circ} \mathrm{C}$ por $24 \mathrm{~h}$. Após este período foi realizada a contagem de colônias nas placas e os resultados foram expressos em log.UFC.g1 .

\subsubsection{Estabilidade físico-química do patê de frango durante o armazenamento}

As análises de $\mathrm{pH}$, parâmetros de cor, índice de peróxido, substâncias reativas ao ácido tiobarbitúrico (TBARS) e quantificação de carbonilas foram realizadas, em triplicata, durante o armazenamento (semanas 1, 3, 5, 7, 10, 13 e 16) das amostras de patê de frango estocadas sob refrigeração.

\subsubsection{Determinação de pH}

Os valores de $\mathrm{pH}$ foram mensurados em temperatura ambiente (aproximadamente $25^{\circ}$ C), utilizando o pHmetro (UltraBasic pH Meter, Denver Instruments, Arvada, CO, EUA) com eletrodo de punção em contato direto com as amostras.

\subsubsection{Determinação de parâmetros de colorimetria instrumental}

Os parâmetros de medição do sistema CIE L*a*b* (luminosidade: L*, teor de vermelho: $a^{*}$ e teor de amarelo: $b^{*}$ ) foram determinados a partir de 3 leituras de cada triplicata das amostras utilizando um colorímetro portátil (MiniScan XE, HunterLab, Reston, VA, EUA), com o iluminante D65, ângulo de observação de $10^{\circ}$ e abertura de célula com $30 \mathrm{~mm}$ (FERNANDES et al., 2014). O índice de intensidade de cor Croma (C*) e o ângulo Hue $\left(\mathrm{H}^{*}\right)$ foram calculados a partir dos valores de $\mathrm{a}^{*}$ e $\mathrm{b}^{*}$, de acordo com as Eq. (7) e (8) (PATEIRO et al, 2014):

$$
\begin{aligned}
& C^{*}=\sqrt{\left(a^{*}\right)^{2}+\left(b^{*}\right)^{2}} \\
& H^{*}=\operatorname{arctg}\left(\frac{b^{*}}{a^{*}}\right) * 57,29
\end{aligned}
$$

A diferença total de cor $(\Delta \mathrm{E})$ entre o início e o fim do armazenamento, obtida a partir da Eq. (9), foi determinada de acordo com Pateiro et al. (2014): 


$$
\Delta E_{(f-i)}=\left[\left(L_{f}-L_{i}\right)^{2}+\left(a_{f}-a_{i}\right)^{2}+\left(b_{f}-b_{i}\right)^{2}\right]^{\frac{1}{2}}
$$

\subsubsection{Avaliação da oxidação lipídica do patê de frango}

A oxidação lipídica foi avaliada pela quantificação do índice de peróxido e das substâncias reativas ao ácido tiobarbitúrico (TBARS), que permitem avaliar a oxidação lipídica primária e secundária, respectivamente.

\subsection{Determinação do índice de peróxido}

Inicialmente, a gordura das amostras foi extraída pelo método de Bligh e Dryer (1959), no qual, foram adicionadas $25 \mathrm{~mL}$ de solução clorofórmio: metanol (7:3, v/v) em 7,5 g de patê de frango e, posteriormente, homogeneizadas em ultra-agitador (T-25, IKA, Staufen, Alemanha) a $16.000 \mathrm{rpm}$ por $2 \mathrm{~min}$. Após esta etapa, foram adicionados $10 \mathrm{~mL}$ de água deionizada e estas amostras foram submetidas à homogeneização nas mesmas condições. Em seguida, as amostras foram centrifugadas a $4^{\circ} \mathrm{C}$ e $4.000 \mathrm{rpm}$ (Z3264K, Hermle Labortechnik, Wehingen, Alemanha) por 3 min e a fase inferior, contendo a gordura e o clorofórmio, foram retiradas. Adicinou-se $1 \mathrm{~g}$ de sulfato de sódio anidro e, posteriormente, as amostras foram filtradas em papel filtro, no qual foram coletados $3 \mathrm{~mL}$ do filtrado e submetidos à secagem em estufa até atingir peso constante.

O índice de peróxido foi determinado de acordo com Pateiro et al. (2014). A gordura extraída da amostra foi dissolvida em $10 \mathrm{~mL}$ de clorofórmio, e em seguida, $15 \mathrm{~mL}$ de ácido acético e $1 \mathrm{~mL}$ de solução aquosa saturada de iodeto de potássio foram adicionados. A mistura foi agitada suavemente durante 1 min e posteriormente, mantida por $5 \mathrm{~min}$ em ambiente escuro. Após esta etapa, $75 \mathrm{~mL}$ de água destilada foram adicionadas e a amostra foi agitada novamente. O iodo liberado foi titulado com tiossulfato de sódio $0,01 \mathrm{M}$, utilizando uma solução indicadora de amido $1 \%$, e o índice de peróxido foi expresso em meqO $2 / \mathrm{kg}$ de amostra de patê de frango.

Antes de realizar a titulação, a solução de tiossulfato de sódio $0,01 \mathrm{M}$ foi padronizada, e para isso, $10 \mathrm{~mL}$ da solução de dicromato de potássio $(0,002 \mathrm{~g} / \mathrm{mL})$ foram adicionadas em 70 $\mathrm{mL}$ de água deionizada. Em seguida, $2 \mathrm{~g}$ de iodeto de potássio e $20 \mathrm{~mL}$ de ácido clorídrico $1 \mathrm{M}$ foram adicionados, e esta mistura foi agitada e mantida em ambiente escuro por $10 \mathrm{~min}$. Após esta etapa, foi adicionado $1 \mathrm{~mL}$ da solução indicadora de amido $1 \%$ e a mistura foi titulada com 
a solução de tiossulfato de sódio $0,01 \mathrm{M}$. O cálculo do fator de correção (f) foi obtido de acordo com a Eq. (10):

$$
\mathrm{f}=\frac{\mathrm{m}}{0,049 \times \mathrm{V} \times \mathrm{M}}
$$

sendo:

$\mathrm{m}=$ massa de dicromato de potássio usados na titulação $(\mathrm{g})$;

$\mathrm{V}=$ volume de solução de tiossulfato de sódio $0,01 \mathrm{M}$ gastos na titulação $(\mathrm{mL})$;

$\mathrm{M}=$ molaridade da solução de tiossulfato de sódio $(0,01 \mathrm{M}$, no caso).

\subsection{Determinação das substâncias reativas ao ácido tiobarbitúrico (TBARS)}

O índice de TBARS foi medido segundo Pateiro et al. (2014), com modificações. A massa de $5 \mathrm{~g}$ da amostra de patê de frango foi dispersa em $10 \mathrm{~mL}$ de ácido tricloroacético 5\% e homogeneizadas em ultra-agitador (T-25, IKA, Staufen, Alemanha) a $14.000 \mathrm{rpm}$ por 2 min. No tratamento 5, contendo nitrito de sódio, foi adicionado $1 \mathrm{~mL}$ de solução de sulfanilamida $(0,1 \mathrm{mg} / \mathrm{mL})$, para eliminar a interferência do nitrito de sódio na quantificação de TBARS. O homogeneizado foi centrifugado à $4^{\circ} \mathrm{C}$ em 2360g (Z3264K, Hermle Labortechnik, Wehingen, Alemanha) por $30 \mathrm{~min}$. O sobrenadante foi filtrado através de um filtro de papel, no qual $5 \mathrm{~mL}$ do filtrado foi misturado com $5 \mathrm{~mL}$ de uma solução de $0,02 \mathrm{M}$ de ácido tiobarbitúrico (TBA) e em seguida, colocado em banho-maria a $96^{\circ} \mathrm{C}$ durante $40 \mathrm{~min}$. A absorbância foi medida a 532 $\mathrm{nm}$ e $600 \mathrm{~nm}$ (para corrigir a turbidez) e os valores do ácido tiobarbitúrico (TBARS) foram calculados a partir de uma curva padrão de malonaldeído (MDA) com 1,1-3,3 tetraetoxipropano. Os valores do índice de TBARS foram expressos em mg MDA/kg de amostra de patê de frango.

A porcentagem de inibição da oxidação lipídica foi calculada na semana 16 de armazenamento, de acordo com a Eq. (11) (ESTÉVEZ et al., 2007):

$$
\text { \% de inibição da oxidação lipídica }=\frac{(\mathrm{C} 16-\mathrm{T} 16)}{\mathrm{C} 16} \text { X } 100
$$

sendo:

C16: quantidade de MDA na semana 16 do tratamento controle (sem antioxidante), no caso, tratamento $\mathrm{T} 1$.

T16: quantidade de MDA na semana 16 do tratamento. 


\subsubsection{Avaliação da oxidação proteica do patê de frango (quantificação de carbonilas totais)}

As carbonilas das proteínas foram determinadas pela quantificação do teor total de carbonilas seguindo a metodologia descrita por Oliver et al. (1987). Massas de $12 \mathrm{~g}$ de amostra de patê de frango foram homogeneizadas com $20 \mathrm{ml}$ de solução tampão de $\mathrm{KCl}$ 0,15 M, durante $60 \mathrm{~s}$ utilizando um ultra-agitador (T-25, IKA, Staufen, Alemanha). Duas alíquotas de 0,1 mL do homogeneizado foram transferidas para tubos Eppendorf, e em seguida, as proteínas foram precipitadas, em ambas as alíquotas, pela adição de $1 \mathrm{~mL}$ de uma solução $10 \%$ de ácido tricloroacético (TCA) e centrifugadas (Z3264K, Hermle Labortechnik, Wehingen, Alemanha) durante 5 min a $5.000 \mathrm{~g}$. Um sedimento foi tratado com $1 \mathrm{ml}$ de solução $\mathrm{HCl} 2 \mathrm{~N}$ para a quantificação de proteína, e no sedimento da outra alíquota foi adicionado $1 \mathrm{~mL}$ de solução $\mathrm{HCl}$ $2 \mathrm{M}$ contendo 0,2 \% de 2,4-dinitrofenil-hidrazina (DNPH) para quantificar o teor de carbonilas. Ambas as amostras foram incubadas por 1 hora em temperatura ambiente, com agitação a cada 20 min. Após a incubação, foram adicionados $0,8 \mathrm{~mL}$ de TCA A $10 \%$ e as amostras foram agitadas por 30 segundos e, posteriomente, centrifugadas (Z3264K, Hermle Labortechnik, Wehingen, Alemanha) durante $5 \mathrm{~min}$ a $500 \mathrm{~g}$. O sobrenadante foi removido e o sedimento lavado três vezes com $1 \mathrm{~mL}$ de acetato de etila-etanol $(1: 1, \mathrm{v} / \mathrm{v})$, em seguida, foram secas em capela de um dia para outro. Por fim, o sedimento foi dissolvido em $2 \mathrm{~mL}$ de guanidina-HCl 6 M em tampão fosfato de sódio $20 \mathrm{mM}$ (pH final 6,5), e após agitação, foi centrifugado (Z 306, Hermle Labortechnik, Wehingen, Alemanha) durante 2 min a $5000 \mathrm{~g}$ para retirar os fragmentos insolúveis. A concentração de proteína foi calculada por absorção a $280 \mathrm{~nm}$, utilizando albumina de soro bovino (BSA) como padrão e a quantidade de carbonilas foi expressa em nmol de carbonila por miligrama de proteína, utilizando um coeficiente de adsorção de 21,0 $\mathrm{mM}^{-1} \mathrm{~cm}^{-1}$ a $370 \mathrm{~nm}$ (LORENZO E GÓMES, 2012).

\subsubsection{Análise sensorial do patê de frango}

A análise sensorial do patê de frango foi realizada no Laboratório de Análise Sensorial da Faculdade de Zootecnia e Engenharia de Alimentos, no Departamento de Engenharia de Alimentos (FZEA/USP), em cabines individuais com luz branca. O projeto de análise sensorial foi submetido e aprovado pelo Comitê de Ética da FZEA/USP (CAAE 59015916.5.0000.5422) 
e o termo de consentimento livre e esclarecido (Apêndice A) foi entregue aos provadores antes de realizar a análise sensorial.

Para estimar o grau de diferença sensorial entre os tratamentos descritos no item 4.2.11, foi realizado o teste de diferença do controle com um painel de 120 provadores. Os testes de aceitação foram realizados com duas finalidades. Primeiramente, objetivou-se verificar se a oxidação do produto cárneo ao longo do período de 90 dias afetaria a aceitação global, o odor e a cor do patê de frango, utilizando-se um painel de 100 provadores. O segundo objetivo foi avaliar o grau de aceitação e de preferência das amostras, e tal análise foi realizada utilizandose 120 provadores. Os painéis de provadores foram obtidos por membros não treinados, de ambos os sexos e constituídos por alunos de graduação, alunos de pós-graduacão, docentes e funcionários do campus da FZEA/USP.

As amostras de patê de frango foram codificadas por três dígitos aleatórios e apresentados aos provadores em uma bandeja com a ficha de avaliação. Nas análises em que o provador teria que avaliar o sabor das amostras, o patê foi oferecido aos provadores em torradas, sendo que para limpeza do paladar utilizou-se água e bolacha do tipo água e sal.

\subsubsection{Análises microbiológicas do patê de frango para realização da análise sensorial}

Foram realizadas as análises de contagem de micro-organismos viáveis totais e enterobactérias nas amostras de patê de frango um dia após a produção do patê. O protocolo de análise foi estabelecido de acordo com Silva et al. (2010), no qual, inicialmente, $25 \mathrm{~g}$ da amostra de cada tratamento foram pesadas assepticamente, em seguida foram adicionados $225 \mathrm{~mL}$ de água peptonada estéril $0,1 \% \mathrm{~m} / \mathrm{v}$ (diluição $10^{-1}$ ) e homogeneizadas por aproximadamente 1 min. O plaqueamento para realizar a contagem dos micro-organismos viáveis totais foi realizado em superfície, no qual $0,1 \mathrm{~mL}$ das diluições foram espalhados em placas com ágar padrão para contagem (PCA), e incubadas a $35 \pm 1^{\circ} \mathrm{C}$ durante $48 \pm 2$ horas. Para as enterobactérias foi realizado o plaqueamento por profundidade com sobrecamada no ágar VRBG (violet red bile glucose), seguida de incubação a $35 \pm 1^{\circ} \mathrm{C}$ por $24 \mathrm{~h}$. Ambas as análises foram realizadas em triplicata. 


\subsubsection{Avaliação do perfil dos provadores da análise sensorial}

A avaliação do perfil dos provadores foi realizada pela classificação dos membros de acordo com: (i) faixa etária; (ii) sexo; (iii) ocupação na faculdade; (iv) grau de instrução do chefe da família; (v) renda familiar e (vi) frequência e local de consumo. A ficha utilizada para a avaliação dos provadores pode ser visualizada no Apêndice B.

\subsubsection{Teste de diferença do controle (análise discriminativa)}

Aos julgadores foram apresentadas a amostra controle e as amostras devidamente codificadas. Cada amostra foi avaliada em relação ao controle segundo os atributos de cor, odor e sabor utilizando uma ficha de avaliação (Apêndice C) com escala de diferença, sendo: $0=$ nenhuma diferença do controle, $1=$ ligeiramente diferente do controle, $2=$ pouco diferente do controle, $3=$ muito diferente do controle, $4=$ muitíssimo diferente do controle, $5=$ extremamente diferente do controle. Os resultados relativos à pontuação atribuída à escala foram avaliados pela Análise de Variância (ANOVA) e pelo teste de média de Dunnett (FARIA; YOTSUYANAGI, 2002).

\subsubsection{Teste de aceitação (análise afetiva)}

O teste de aceitação foi realizado em duas etapas. Na primeira etapa, foram realizadas quatro seções de análise sensorial, nos dias 1, 30, 60 e 90 de armazenagem do patê de frango sob refrigeração, nas quais foi empregada a ficha de avaliação do Apêndice D. Na segunda etapa, foi realizada a análise em uma seção, utilizando a ficha de avaliação do Apêndice E para estimar a aceitação dos produtos submetidos aos tratamentos descritos no item 4.2.11. Nesta última etapa, também foi realizada uma intenção de compra dos produtos, utilizando a escala de intenção de compra: 5 = certamente compraria o produto, $4=$ possivelmente compraria o produto, 3 = talvez compraria / talvez não compraria, 2 = possivelmente não compraria $o$ produto e 1 = certamente não compraria o produto.

Os provadores receberam as amostras codificadas e avaliaram a aceitação dos atributos sensoriais de acordo com a escala hedônica estruturada de 9 pontos, sendo: 1= desgostei muitíssimo, $2=$ desgostei muito, $3=$ desgostei regularmente, $4=$ desgostei ligeiramente, $5=$ indiferente, $6=$ gostei ligeiramente, $7=$ gostei regularmente, $8=$ gostei muito e $9=$ gostei muitíssimo. A análise estatística dos resultados obtidos com a escala hedônica foi realizada por 
análise de variância (ANOVA) para avaliar se há diferença significativa entre as amostras, e posteriormente, foi utilizado o teste de Tukey para a comparação entre as médias (DUTCOSKY, 2011).

\subsubsection{Análises estatísticas}

Para obtenção das análises estatísticas dos resultados, utilizou-se o software estatístico SAS 9.2, o qual foi aplicado o teste de médias (Tukey) ao nível de 5\% de significância. 


\section{RESULTADOS E DISCUSSÃO}

\subsection{Produção e caracterizacão das nanoemulsões}

\subsubsection{Determinação da temperatura de transição de fases na produção das nanoemulsões}

As temperaturas de transição de fases (TPIT) das nanoemulsões foram determinadas pela condutividade elétrica das amostras com o aumento gradativo da temperatura. Observou-se o declínio da condutividade das formulações, apresentado na Figura 15, com o aumento da temperatura, e segundo Anton e Vandamme (2009), este comportamento é indicativo de inversão de fases a partir de uma emulsão $\mathrm{O} / \mathrm{A}$, com uma fase aquosa contínua (alta condutividade), para uma emulsão A/O, com uma fase contínua oleosa (baixa condutividade).

O pico de condutividade elétrica observado após a inversão de fases, conforme a Figura 15, está relacionado com a formação de estruturas das fases cristalina líquida e bicontínua, tipicamente associadas à formação de nanoemulsões (IZQUIERDO et al., 2004; GOMES, 2017). Esta região de transição de inversão de fases da emulsão ocorre devido à formação de uma microemulsão bicontínua em equilíbrio, que pode ser do tipo Winsor III (fase oleosa, aquosa e microemulsão bicontínua em equilíbrio) ou do tipo Winsor IV (fase única de microemulsão bicontínua), dependendo da quantidade do tensoativo (ANTON; BENOIT; SAULNIER, 2008b). Tadros et al. (2004) e Anton, Benoit e Saulnier (2008b) observaram este comportamento em nanoemulsões com concentração de tensoativo acima de 5 e $9 \%(\mathrm{~m} / \mathrm{m})$, respectivamente, e o mesmo comportamento pôde ser observado neste estudo em ambas as nanoemulsões, que continham 13 e $20 \%$ de tensoativos, NA-3,25 e NA-5, respectivamente.

Os diferentes perfis de condutividade em função da temperatura das nanoemulsões, portanto, dependem da concentração interfacial do tensoativo, e com isso, tanto o pico de condutividade, quanto o deslocamento da curva, podem vir de tal comportamento interfacial do tensoativo. Entretanto, a razão pela qual ocorre esse aumento na condutividade elétrica ainda permanece mal compreendida, mas supõe-se que as geometrias intermediárias formadas durante a inversão de fases podem criar canais condutores entre os dois eletrodos do condutivímetro, resultando num aumento aparente da condutividade elétrica (ANTON; BENOIT; SAULNIER, 2008b). 
Figura 15. Condutividade elétrica em função da temperatura das nanoemulsões, produzidas pelo método PIT, para determinação da temperatura de inversão de fases: (•) nanoemulsões NA-3,25 e (घ) nanoemulsões NA-5.

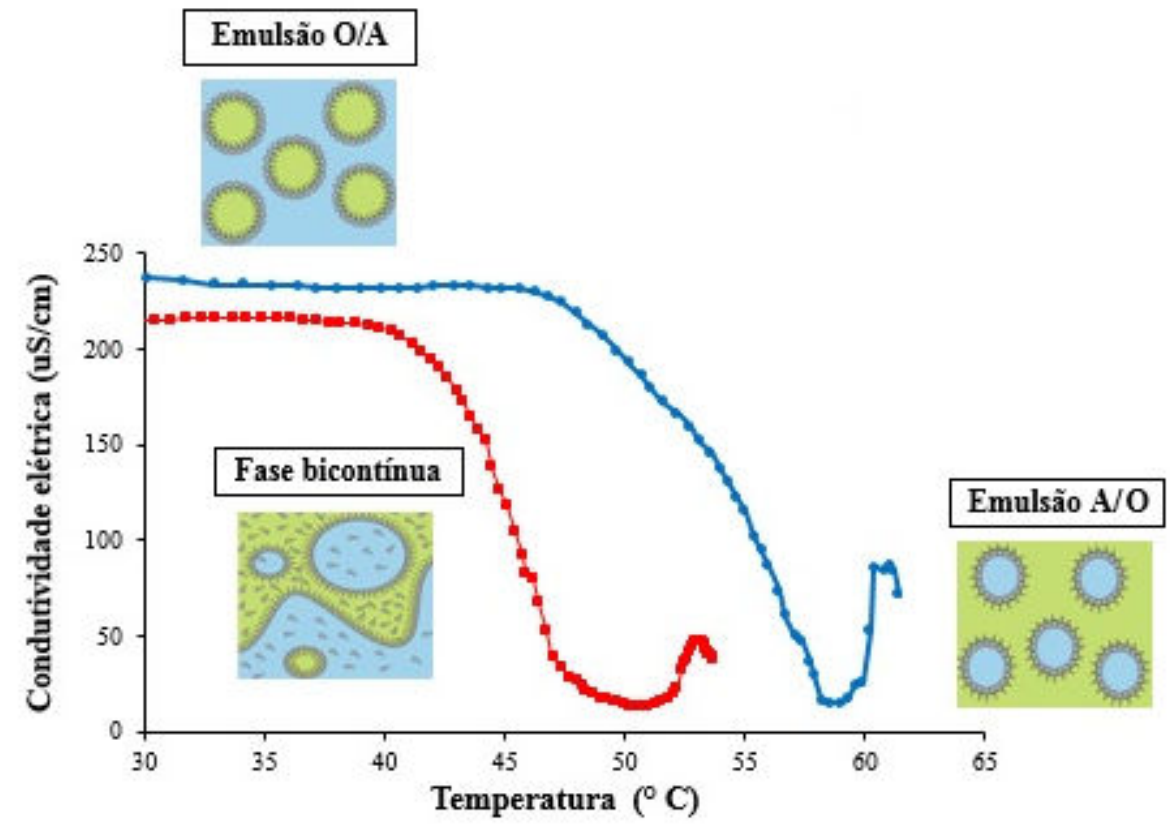

Fonte: Própria autoria.

Trabalhos realizados avaliando a condutividade $v s$ temperatura de sistemas variando a concentração dos tensoativos (TADROS et al., 2004; IZQUIERDO et al., 2004; ANTON; BENOIT; SAULNIER, 2008b) mostraram uma relação entre concentração do tensoativo e a

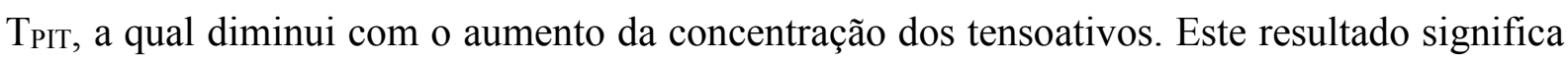
que a composição na interface $\mathrm{A} / \mathrm{O}$ é modificada, envolvendo alterações nas propriedades da interface, tensão interfacial e curvatura interfacial (em função da temperatura) (ANTON; BENOIT; SAULNIER, 2008b). O mesmo comportamento pôde ser observado neste estudo, no qual as nanoemulsões NA-5 com concentração de $20 \%(\mathrm{~m} / \mathrm{m})$ tensoativos obtiveram menor $\mathrm{T}_{\mathrm{PIT}}, 44^{\circ} \mathrm{C}$, em relação às nanoemulsões NA-3,25 com $13 \%(\mathrm{~m} / \mathrm{m})$, na qual a $\mathrm{T}_{\mathrm{PIT}}$ foi de $52^{\circ}$ C.

O comportamento da condutividade do sistema tensoativo-óleo-água, em relação à temperatura, contendo uma concentração maior de OEO $(7 \% \mathrm{~m} / \mathrm{m})$ e mantendo a concentração de água e tensoativos, foi bastante diferente das nanoemulsões contendo $5 \%$ de OEO, indicando que a inversão de fases não ocorreu de forma eficiente, devido à alta quantidade de OEO e possivelmente este fato está associado com a maior contribuição dos triglicerídios do óleo de 
girassol, em relação ao OEO, na formação da interface, e consequentemente, na formação de fases bicontínuas e lamelares (MORAES-LOVISON et al., 2017).

A compatibilidade entre as cadeias da porção hidrofóbica do tensoativo, e da fase oleosa são determinantes para a formação da interface em emulsões (TANAKA et al., 2003). O óleo de girassol, por também ser rico em cadeias C18 na sua composição, apresenta compatibilidade com o tensoativo Cremophor RH-40, o qual foi empregado em ambas as formulações das nanoemulsões, e portanto, estas substâncias podem ter tido interações de cadeia favoráveis na interface da fase oleosa e do tensoativo para a formação das nanoemulsões. Entretanto, a utilização de concentrações mais elevadas de Cremophor RH40 (acima de $12 \%$ m/m) não foi adequada para a produção de nanoemulsões por inversão de fases, uma vez que houve separação de fases no processo de resfriamento. Provavelmente, este comportamento ocorreu devido à dificuldade em desidratar a cabeça polar deste tensoativo durante o resfriamento no método de temperatura de inversão de fases, uma vez que a parte polietoxilada de Cremophor RH40, altamente volumosa (tem 40 grupos de polietoxileno) é facilmente hidratada, mas provavelmente não desidrata rápido o suficiente para permitir a inversão de fases do sistema (MORAES-LOVISON et al., 2017).

\subsubsection{Avaliação da estabilidade físico-química das nanoemulsões durante a armazenagem}

As nanoemulsões NA-3,25, obtidas a partir de uma mistura de tensoativos Cremophor RH40 e Brij 30, apresentaram tamanho médio de gota de 25,5 $\pm 0,21 \mathrm{~nm}$ e as nanoemulsões NA5, produzida com uma mistura de tensoativos Cremophor RH-40 e Span 80, apresentaram tamanho médio de gota de 42,4 $\pm 1,7 \mathrm{~nm}$. O tamanho inicial das nanoemulsões é determinado pela geometria molecular e pelo empacotamento das moléculas dos tensoativos, sendo que a geometria dos tensoativos é um dos parâmetros mais importantes que influenciam sua capacidade de formar nanoemulsões com tamanho de gotas reduzidas (McCLEMENTS, 2012; MAYER; WEISS; McCLEMENTS, 2013).

Um estudo realizado por Wang et al. (2009) avaliou o tamanho de gota das nanoemulsões produzidas com uma combinação de tensoativos Tween e Span, e observou que a mistura do Tween 80 (com uma cadeia hidrofóbica C18) com o Span 20 (com uma cadeia hidrofóbica C12) produziu nanoemulsões com diâmetro médio de gota de 44,7 nm, enquanto na mistura do Tween 80 com o Span 60 (C18) este valor foi de $66,7 \mathrm{~nm}$. Os autores associaram o aumento no tamanho das nanoemulsões com o aumento no comprimento da cadeia do 
tensoativo lipófilo, o qual aumentou de 12 para 18, uma vez que as diferenças no empacotamento de tensoativos na interface óleo-água influenciam nas propriedades de tensão superficial e mobilidade, as quais desempenham um papel importante no tamanho de gotas utilizando métodos de baixa energia (MAYER; WEISS; McCLEMENTS, 2013).

O mesmo comportamento pôde ser observado com as nanoemulsões em estudo, as quais apresentaram maior tamanho de gota obtidas a partir da mistura dos tensoativos Cremophor RH-40 (C18) e Span 80 (C18) em comparação com as misturas de tensoativos Cremophor RH-40 (C18) e Brij 30 (C12), e, portanto, o tamanho da cadeia de carbonos da parte lipofílica dos tensoativos Span 80 e Brij 30 afetou o tamanho de gota das nanoemulsões.

Além disso, segundo Anton e Vandamme (2009), o tamanho de gota das nanoemulsões também pode estar relacionado com as variáveis da formulação, as quais podem ser associadas com a razão tensoativo/óleo (SOR) e água/óleo (WOR), como descrito em Eq. (12) e (13), respectivamente:

$$
\begin{aligned}
& \text { SOR }=\frac{\text { massa }_{\text {tensoativo }}}{\left(\text { massa }_{\text {tensoativo }}+\text { massáleo }_{\text {ól }}\right)} \\
& \text { WOR }=\frac{\text { massáágua }_{\text {án }}}{\left(\text { massa }_{\text {água }}+\text { massa }_{\text {óleo }}\right)}
\end{aligned}
$$

Entretanto, as nanoemulsões encapsulando OEO, apresentaram valores iguais de SOR 0,67, sendo que os valores de WOR foram muito próximos, 0,925 e 0,875, para as nanoemulsões NA-3,25 e NA-5, respectivamente. Portanto a diferença de tamanho médio de gota observada entre as nanoemulsões não está associada com as relações tensoativo/óleo e água/óleo, mas sim, provavelmente, com o tipo de tensoativo empregados na formulação das nanoemulsões (conforme descrito anteriormente).

A estabilidade das nanoemulsões durante o período de armazenamento das amostras sob refrigeração foi realizada pela determinação do diâmetro hidrodinâmico médio das gotas, do índice de polidispersidade (PDI), da turbidez e da distribuição de tamanho de gota, e os dados estão mostrados nas Tabelas 4 e 5 e na Figura 16.

Ao final do período de 90 dias de armazenamento, os índices de polidispersidade foram de 0,04 e 0,12 $\pm 0,02$ para as nanomeulsões NA-3,25 e NA-5, respectivamente, indicando que as nanoemulsões apresentaram estreita distribuição de tamanho de gotas durante todo o armazenamento, uma vez que os valores de PDI foram baixos e inferiores a 0,2. As curvas de 
distrinuição de tamanho de gota (Figura 16), mostram que para ambas as nanoemulsões não houve uma diferença no comportamento da curva monomodal tanto no início quanto no fim do período de 90 dias de armazenamento, e portanto, apresentaram um sistema com tamanho de gotas homogêneos, que favorece a estabilidade das nanoemulsões durante o armazenamento.

Em ambas as nanoemulsões não houve diferença significativa $(\mathrm{p}<0,05)$ nos valores médios de diâmetro hidrodinâmico entre o início e o final do armazenamento, e portanto, podese considerar que nanoemulsões permaneceram cineticamente estáveis durante 90 dias. Esta estabilidade das nanoemulsões observada durante o armazenamento está relacionada com o

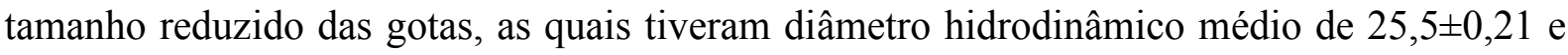
$42,4 \pm 1,7 \mathrm{~nm}$ para as nanoemulsões NA-3,25 e NA-5, respectivamente. O pequeno tamanho de gotas de nanoemulsões confere estabilidade contra a sedimentação ou cremeação porque o movimento Browniano e, consequentemente, a taxa de difusão é superior à taxa de sedimentação ou cremeação, a qual é induzida pela força de gravidade, e também, o tamanho reduzido das nanoemulsões impede a desestabilização física por floculação e coalescência, permitindo assim, que as nanoemulsões permaneçam estáveis por um longo período de tempo (TADROS et al., 2004; SOLANS et al., 2005).

Tabela 4. Valores médios do diâmetro hidrodinâmico (DH), índice de polidispersidade (PDI) e turbidez das nanoemulsões NA-3,25 durante o período de 90 dias das amostras armazenadas sob refrigeração.

\begin{tabular}{lllllllll}
\hline \multicolumn{7}{c}{ Nanoemulsões NA-3,25 } \\
\hline & Dia 1 & Dia 11 & Dia 21 & Dia 27 & Dia 60 & Dia 75 & Dia 90 & Sig. \\
\hline DH (nm) & $25,5 \pm 0,21$ & $24,8 \pm 1,56$ & $24,6 \pm 1,34$ & $23,1 \pm 0,57$ & $23,9 \pm 0,28$ & $24,3 \pm 0,57$ & $23,8 \pm 0,85$ & n.s. \\
PDI & $0,05 \pm 0,01$ & $0,08 \pm 0,06$ & $0,04 \pm 0,05$ & $0,05 \pm 0,00$ & $0,07 \pm 0,02$ & $0,04 \pm 0,04$ & $0,04 \pm 0,00$ & n.s. \\
Turbidez & $0,08 \pm 0,05^{\mathrm{b}}$ & $0,10 \pm 0,03^{\mathrm{b}}$ & $0,07 \pm 0,02^{\mathrm{b}}$ & $0,17 \pm 0,07^{\mathrm{b}}$ & $0,08 \pm 0,03^{\mathrm{b}}$ & $0,15 \pm 0,02^{\mathrm{b}}$ & $0,87 \pm 0,4^{\mathrm{a}}$ & $*$ \\
\hline
\end{tabular}

${ }^{\mathrm{a}-\mathrm{b}}$ - Médias seguidas com a mesma letra na mesma linha não se diferenciam ao nível de significância de $5 \%$, pelo teste de Tukey.

Sig.= Significância: * significativo ao nível de $5 \%$ de probabilidade $(\mathrm{p}<0,05)$, n.s. não significativo $(\mathrm{p}$ $>=0,05)$.

Fonte: Própria autoria. 
Tabela 5. Valores médios do diâmetro hidrodinâmico (DH), índice de polidispersidade (PDI) e turbidez das nanoemulsões NA-5 durante o período de 90 dias das amostras armazenadas sob refrigeração.

\begin{tabular}{llllllllc}
\hline \multicolumn{7}{c}{ Nanoemulsões NA-5 } \\
\hline & Dia 1 & Dia 9 & Dia 20 & Dia 30 & Dia 60 & Dia 75 & Dia 90 & Sig. \\
\hline DH (nm) & $42,4 \pm 1,7^{\text {ab }}$ & $37,3 \pm 1,4^{\mathrm{b}}$ & $39,6 \pm 1,6^{\text {ab }}$ & $44,1 \pm 4,1^{\text {ab }}$ & $41,0 \pm 2,0^{\mathrm{a}}$ & $42,7 \pm 1,2^{\mathrm{ab}}$ & $42,6 \pm 1,1^{\mathrm{ab}}$ & $*$ \\
PDI & $0,09 \pm 0,01$ & $0,09 \pm 0,00$ & $0,11 \pm 0,03$ & $0,05 \pm 0,05$ & $0,12 \pm 0,01$ & $0,12 \pm 0,03$ & $0,12 \pm 0,02$ & n.s. \\
Turbidez & $0,68 \pm 0,05^{\mathrm{d}}$ & $0,76 \pm 0,02^{\text {cd }}$ & $0,80 \pm 0,03^{\mathrm{c}}$ & $0,82 \pm 0,03^{\mathrm{c}}$ & $0,98 \pm 0,04^{\mathrm{b}}$ & $1,17 \pm 0,10^{\mathrm{a}}$ & $1,15 \pm 0,07^{\mathrm{a}}$ & $*$ \\
\hline
\end{tabular}

${ }^{\text {a-d }}$ - Médias seguidas com a mesma letra na mesma linha não se diferenciam ao nível de significância de $5 \%$, pelo teste de Tukey.

Sig.= Significância: * significativo ao nível de $5 \%$ de probabilidade $(\mathrm{p}<0,05)$, n.s. não significativo ( $\mathrm{p}$ $>=0,05)$.

Fonte: Própria autoria.

Figura 16. Curvas de distribuição de tamanho de gotas para as nanoemulsões NA 3,25 e NA-5 durante o início e o final do armazenament sob refrigeração: $(\rightarrow)$ dia 1 e $(\rightarrow-)$ dia 90.
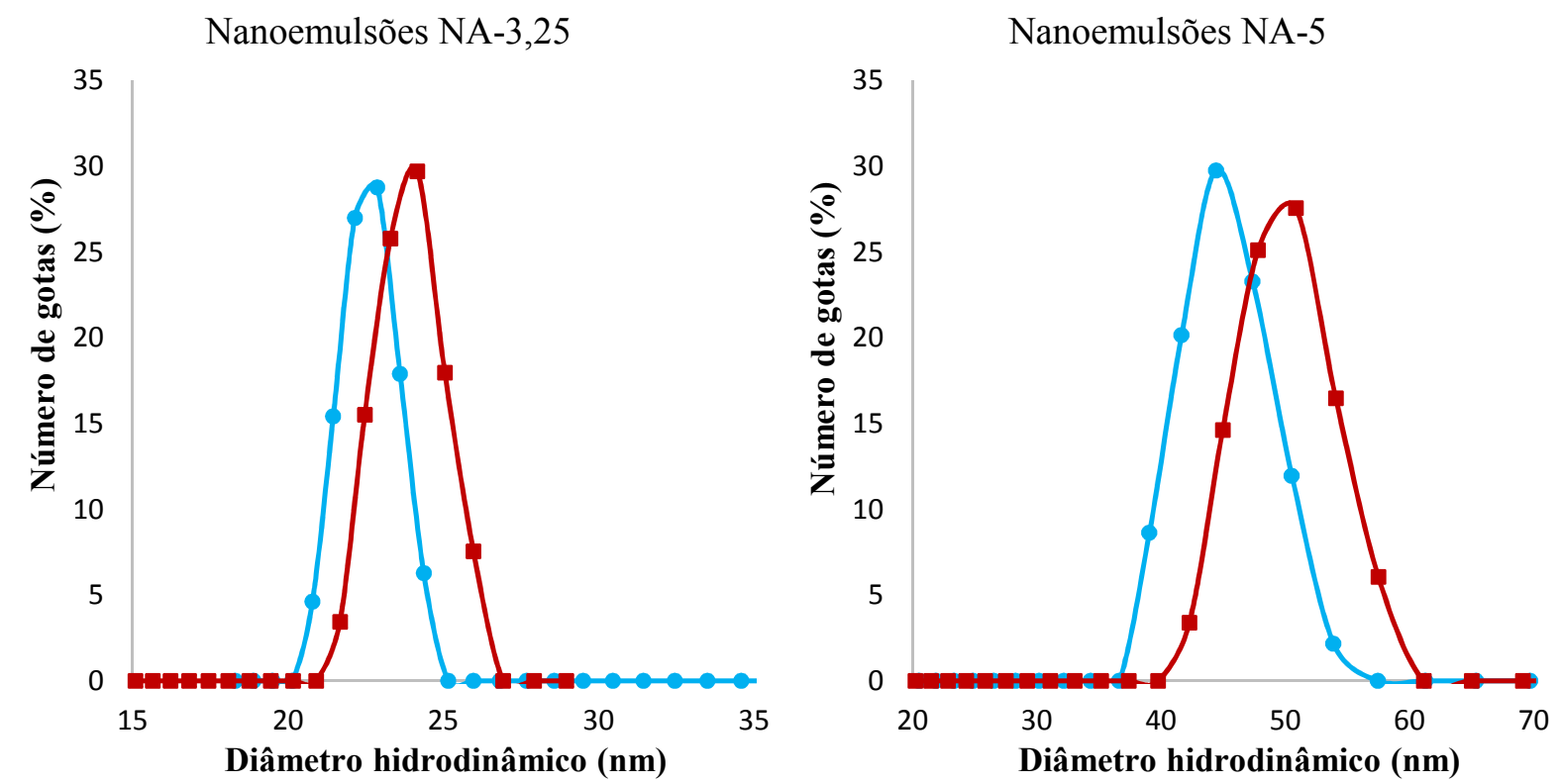

Em relação à turbidez, as amostras recém-produzidas de nanoemulsões NA-3,25 apresentaram turbidez $(0,08 \pm 0,05)$ significativamente menores $(\mathrm{p}<0,05)$ em relação às nanoemulsões NA-5 $(0,68 \pm 0,05)$, conforme Tabelas 4 e 5 . A turbidez das nanoemulsões depende do tamanho médio das gotas, sendo que a turbidez da nanodispersão será menor quanto menor for este tamanho médio tornando assim o sistema nanoemulsionado mais opticamente transparente (GHOSH; MUKHERJEE; CHANDRASEKARAN, 2014). Ghosh, Mukherjee e 
Chandrasekaran (2014) observaram que nanoemulsões encapsulando eugenol com tamanho de gota de $13 \pm 3,1$ e $20 \pm 4,5 \mathrm{~nm}$ se apresentaram oticamente transparentes, enquanto nanoemulsões com $84 \pm 4,2$ e $117 \pm 6,3 \mathrm{~nm}$ foram translúcidas e com $191 \pm 5,9 \mathrm{~nm}$ se mostraram oticamente turvas. Portanto, os menores valores de turbidez, e consequentemente, a maior trasparência das nanoemulsões NA-3,25 estão relacionadas ao menor tamanho de gota, que foi de 25,5 $\pm 0,21$ $\mathrm{nm}$, em relação às nanoemulsões NA-5, com tamanho de gota de $42,4 \pm 1,7 \mathrm{~nm}$, conforme Figura 17.

Figura 17. Aspecto visual das nanoemulsões NA-3,25 (A) e NA-5 (B), produzidas pelo método PIT, no dia 1 e após 90 dias de armazenamento.

(A)

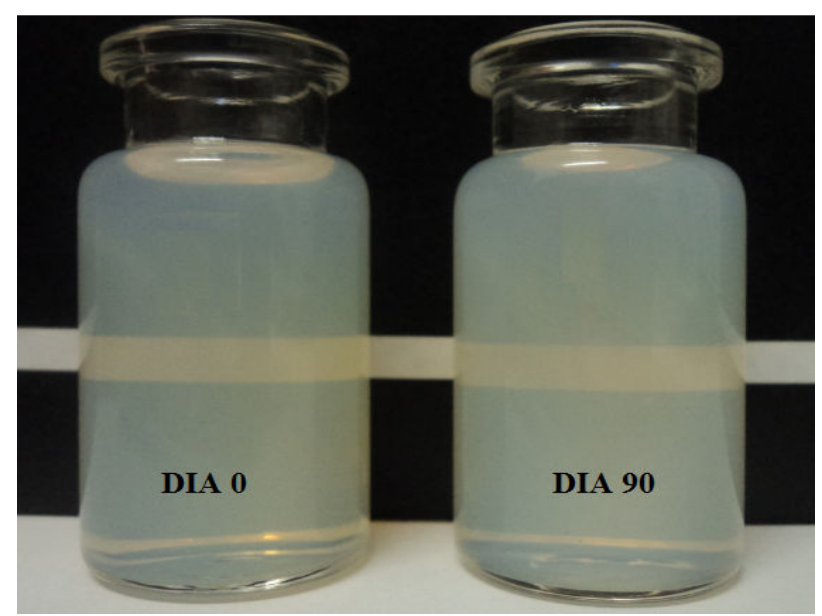

(B)

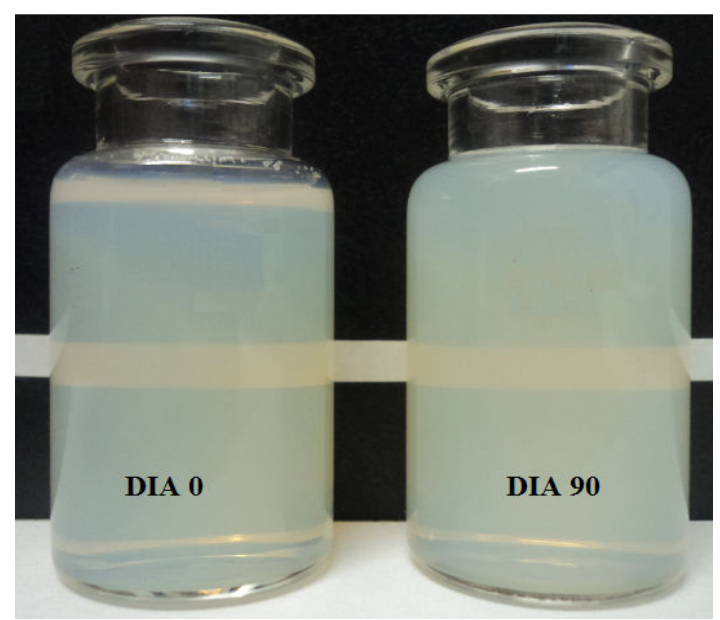

Fonte: Própria autoria.

Durante o período de 90 dias de armazenamento houve um aumento significativo ( $\mathrm{p}<$ $0,05)$ na turbidez para ambas as nanoemulsões (Tabelas 4 e 5). Entretanto, apesar do aumento

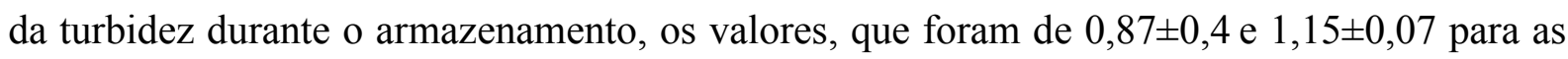
nanoemulsões NA-3,25 e NA-5, respectivamente, ainda são considerados baixos para que ocorra a desestabilização dos sistemas nanoemulsionados. Na Figura 17 é possível observar que, apesar do aumento da turbidez, ambas as nanoemulsões permaneceram estáveis durante o período de 90 dias de armazenamento sob refrigeração.

Entretanto, um dos principais mecanismos de desestabilização de nanoemulsões é por maturação de Ostwald, o qual resulta da diferença de solubilidade entre pequenas e grandes gotículas (SOLANS et al., 2005). Analiticamente, a inclinação de uma relação linear entre o 
raio da emulsão ao cubo $\left(\mathrm{r}^{3}\right)$ com o tempo, está relacionada com a taxa de maturação de Ostwald (teoria LSW) (LIFSHITZ; SLYOZOV, 1961; WAGNER, 1961; WOOSTER; GOLDING; SANGUANSRI, 2008). A taxa de maturação de Ostwald durante o armazenamento está relacionada com a teoria LSW, de acordo com a Eq. (14):

$$
\omega=\frac{d r^{3}}{d t}=\frac{8}{9}\left[\frac{C(\infty) \gamma V_{m} D}{\rho R T}\right]
$$

sendo: $\omega=$ a taxa de maturação de Ostwald; $\mathrm{C}(\infty)=$ a solubilidade dos óleos na fase contínua; $\mathrm{r}=\mathrm{o}$ raio da gota das nanoemulsões; $\gamma=\mathrm{a}$ tensão interfacial; $\mathrm{D}=\mathrm{o}$ coeficiente de difusão da fase dispersa na fase contínua; $\mathrm{V}_{\mathrm{m}}=\mathrm{o}$ volume molar do óleo; $\mathrm{R}=\mathrm{a}$ constante universal do gás; $\mathrm{T}=$ a temperature absoluta; e $\rho=$ a densidade da fase dispersa.

A maturação de Ostwald é um problema comum na instabilidade de emulsões contendo óleos essenciais devido à solubilidade destes óleos em soluções aquosa, aumentando a difusão das moléculas de óleo na fase aquosa (CHANG; McLANDSBOROUGH; McCLEMENTS, 2012), e com isso, este fenômeno de instabilidade tem sido relatado por muitos pesquisadores ao encapsular óleos essenciais de limão, tomilho, menta e os compostos carvacrol, eugenol, e D-limoneno (McCLEMENTS et al., 2012; ZIANI et al., 2011; LIANG et al., 2012; TERJUNG et al., 2012; DONSİ et al., 2011). A Figura 18 mostra que não houve desestabilização física por maturação de Ostwald durante 90 dias de armazenamento, uma vez que não foi observado um aumento no valor de $\mathrm{r}^{3}$ ao longo do tempo para ambas as nanoemulsões. 
Figura 18.Valor de $\mathrm{r} 3$ (nm3) das nanoemulsões vs tempo, durante o armazenamento sob refrigeração: $(\bullet)$ nanoemulsões NA-3,25 e (•) nanoemulsões NA-5.

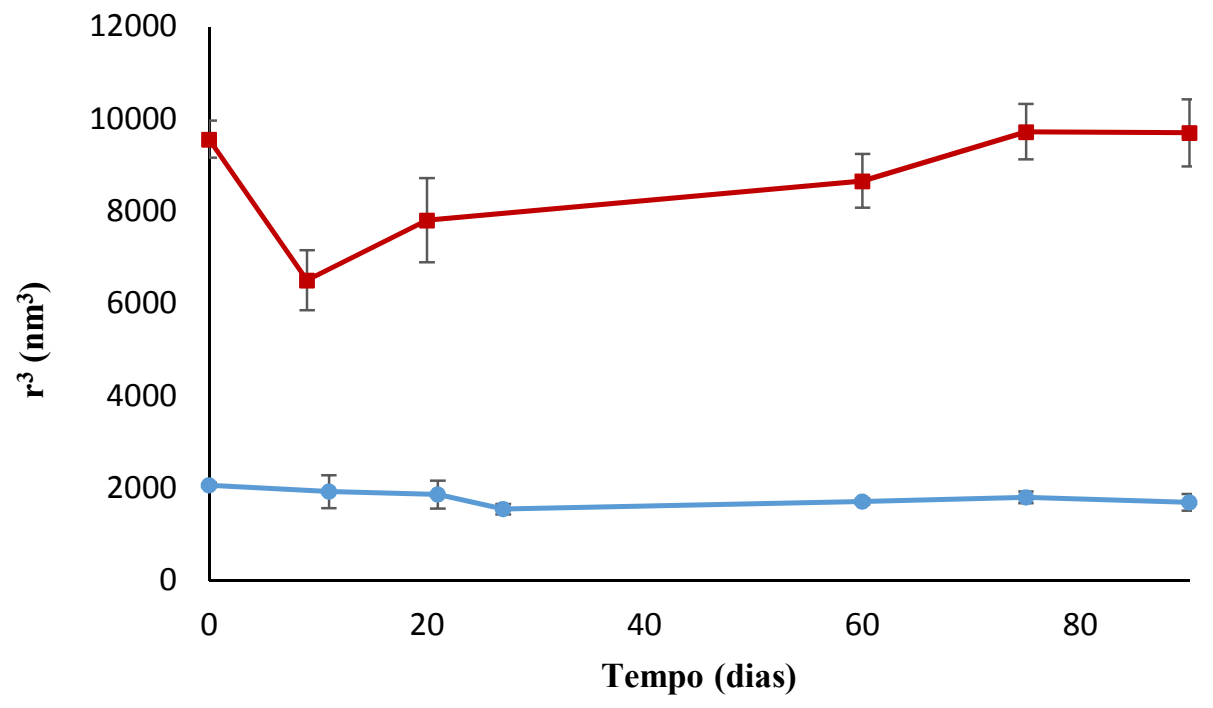

Fonte: Própria autoria.

No presente estudo, provavelmente a desestabilização dos sistemas nanoemulsionados por maturação de Ostwald foi inibida pela adição do óleo de girassol, o qual devido ao grande volume molar das longas cadeias dos triglicerídeos do óleo $\left(\sim 900 \mathrm{~cm}^{3} \mathrm{~mol}-{ }^{1}\right)$, se torna insolúvel na fase aquosa (WOOSTER; GOLDING; SANGUANSRI, 2008). Como consequência há uma redução do coeficiente de difusão do óleo na fase aquosa (D) e na solubilidade dos óleos fase contínua $\mathrm{C}(\infty)$, e pela relação diretamente proporcional dos valores de $\mathrm{D}$ e $\mathrm{C}(\infty)$, conforme a Eq. (14), quanto menor forem esses valores, menor será a taxa de maturação de Ostwald (ZIANI et al., 2011).

\subsection{Quantificação dos compostos voláteis do OEO nanoemulsionado durante o armazenamento}

Inicialmente foi realizado a identificação dos compostos presentes no OEO em estudo, uma vez que, a composição de óleos essenciais a partir de uma determinada espécie de planta varia muito entre as estações de colheita e as fontes geográficas (Burt, 2004). O perfil dos compostos presentes no OEO foi realizado pela identificação dos compostos analisados (timol, carvacrol e $\gamma$-terpineno) a partir do tempo de retenção na coluna (Figura 19) e apresentou como 
componente majoritário o carvacrol $(73,97 \%)$, sendo que o timol e o $\gamma$-terpineno apresentaram valores de $2,45 \%$ e $4,17 \%$, respectivamente.

Figura 19. Cromatograma do óleo essencial de orégano puro.

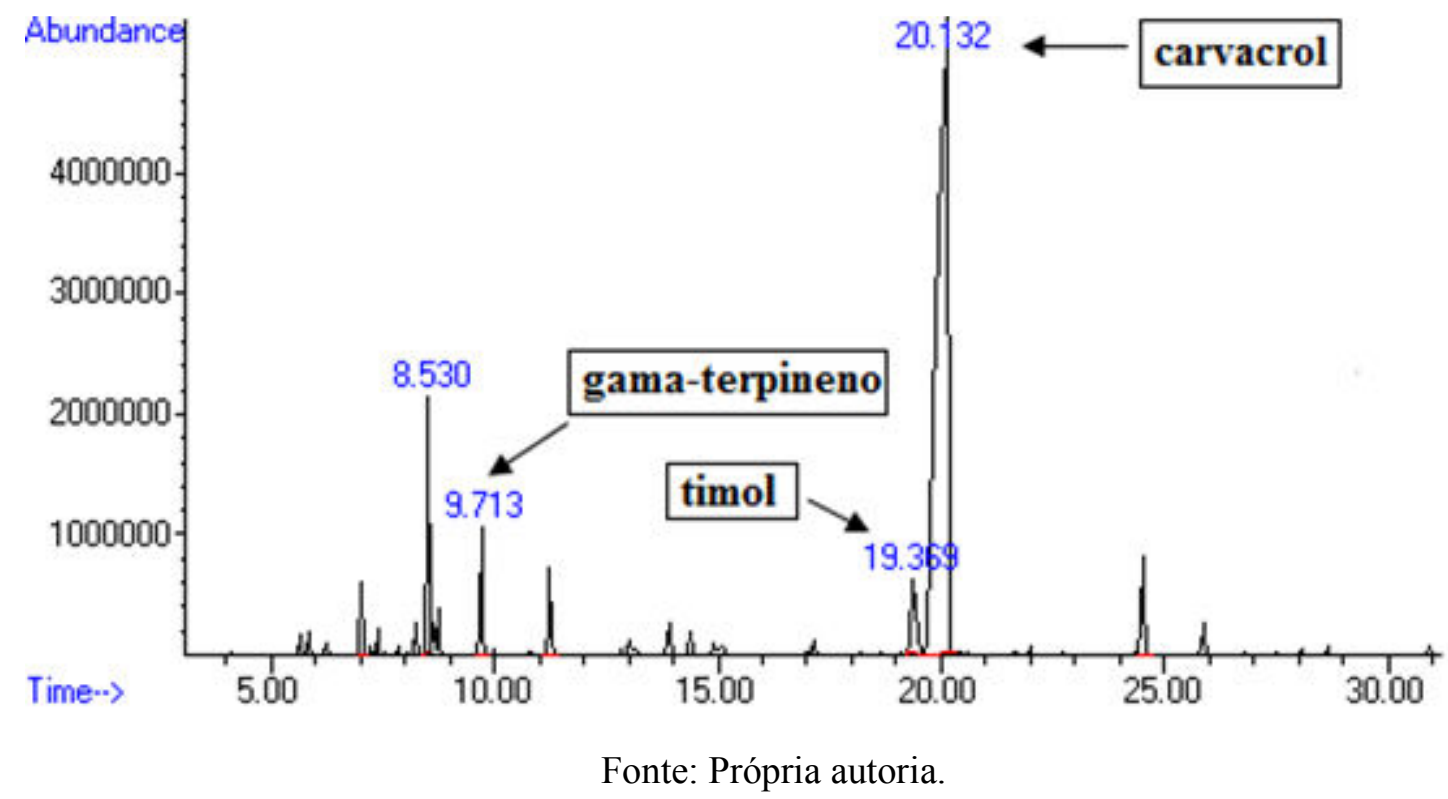

Os gráficos apresentados nas Figuras 20 e 21 mostram a perda dos compostos voláteis durante um período de 60 dias de armazenamento das nanoemulsões. O comportamento da perda dos compostos voláteis foi semelhante para ambas as nanoemulsões, sendo que as nanoemulsões NA-3,25 apresentaram uma perda de 46,4\% de carvacrol, 10,4 \% de timol e 93 $\%$ de $\gamma$-terpineno e para as nanoemulsões NA-5, esta perda foi de 49,9\%, 23,7 \% e 93,3\% para os compostos carvacrol, timol e $\gamma$-terpineno, respectivamente. 
Figura 20. Quantificação dos compostos voláteis presentes no óleo essencial de orégano nanoemulsionado durante o período de 60 dias de armazenamento sob refrigeração das nanoemulsões NA-3,25: $(\bullet)$ carvacrol, $(\square) \gamma$-terpineno e $(\boldsymbol{\Delta})$ timol.

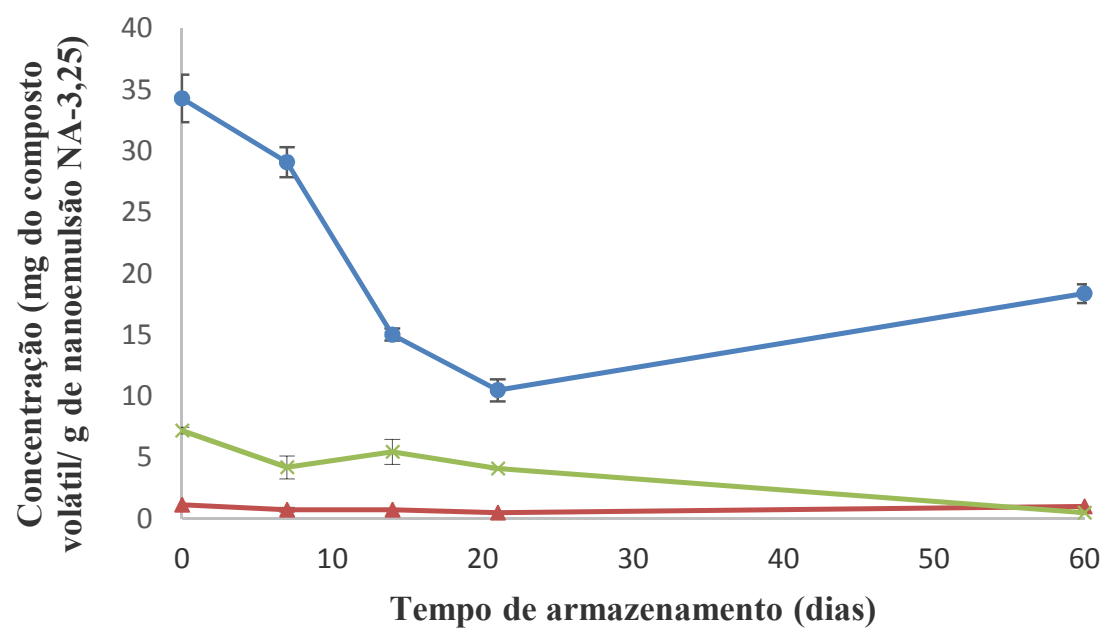

Fonte: Própria autoria.

Figura 21. Quantificação dos compostos voláteis presentes no OEO nanoelsionado durante o período de 60 dias de armazenamento sob refrigeração das nanoemulsões NA-5: (•) carvacrol, ( $\square$ ) $\gamma$-terpineno e ( $\Delta)$ timol.

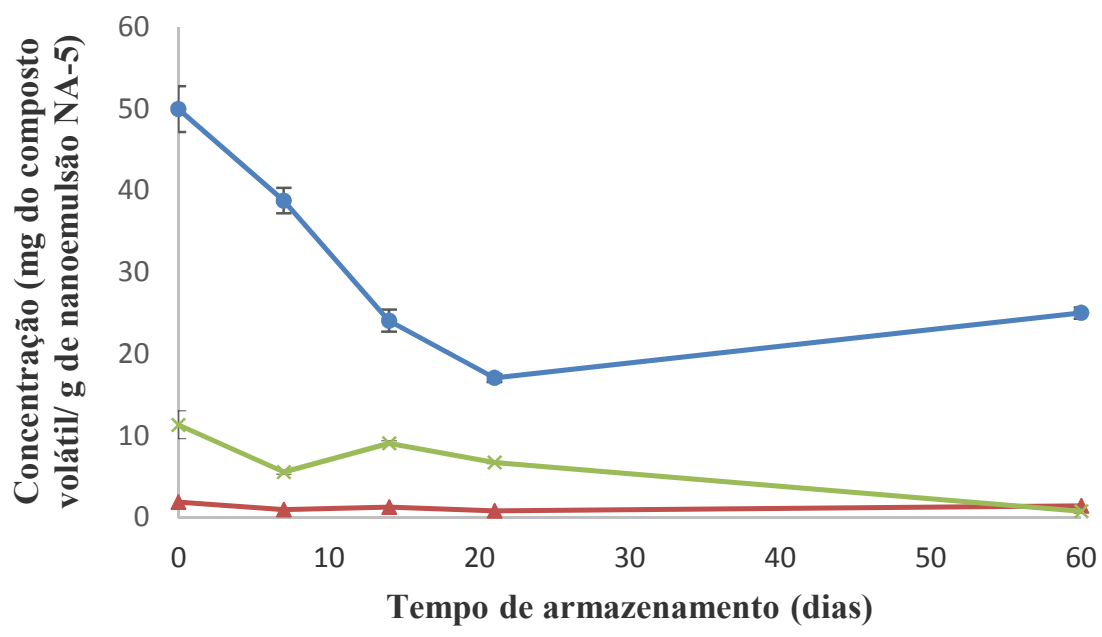

Fonte: Própria autoria. 
A capacidade das nanoemulsões para liberar determinados componentes, como os constituintes voláteis do $\mathrm{OEO}$, depende das características moleculares destes componentes, assim como da composição (tipos de tensoativos, água e fase oleosa) das nanoemulsões, sendo que o perfil de liberação com o tempo, de moléculas voláteis hidrofóbicas a partir de nanoemulsões é fortemente dependente da concentração de lipídios do sistema (McCLEMENTS 2011).

A concentração de um componente volátil, como o carvacrol, timol e $\gamma$-terpineno, liberado pela nanoemulsão com o tempo é governada pelo equilíbrio dos seus coeficientes de partição entre ar-água (K $\left.\mathrm{K}_{\mathrm{AW}}\right)$ e óleo-água (Kow) (McCLEMENTS, 2011). O tamanho reduzido das gotas em nanoemulsões apresentam implicações na taxa de liberação de quaisquer substâncias encapsuladas através de processos de transporte de massa, e uma medida conveniente da velocidade de liberação é o tempo necessário para que metade do composto seja difundido para fora das gotas $\left(\mathrm{t}_{1 / 2}\right)$, conforme Eq. (15) (McCLEMENTS, 2011):

$$
t_{1 / 2}=\frac{0,0585 \times r^{2} \times k_{o w}}{D}
$$

Portanto, de acordo com a Eq. $(15)$, as perdas significativas $(\mathrm{p}<0,05)$ dos constituintes voláteis pelas nanoemulsões NA-3,25 e NA-5 foram observadas durante 60 dias de armazenamento, e estão diretamente relacionadas com o elevado coeficiente de partição dos compostos voláteis carvacrol, timol e $\gamma$-terpineno na água, fase contínua do sistema nanoemulsionado.

\subsection{Avaliação da atividade antimicrobiana in vitro das nanoemulsões}

As concentrações inibitórias mínimas (CIM) e bactericidas mínimas (CBM) para $S$. aureus e E. coli das nanoemulsões encapsulando OEO, durante os dias 1, 30, 60 e 90 de armazenamento, podem ser observadas nas Tabelas 6 e 7. Foram determinadas as CIM e CBM ao longo do tempo para verificar se a perda dos compostos voláteis, os quais conferem ação antibacteriana, afetaria o potencial das nanoemulsões contra as bactérias ao longo do tempo.

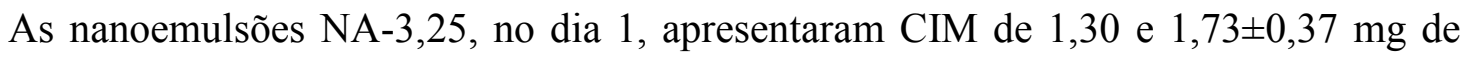
$\mathrm{OEO} / \mathrm{mL}$, para $S$. aureus e E. coli, respectivamente, entretanto, valores superiores foram determinados na CBM, os quais foram $3,67 \pm 0,37$ e 3,46 $\pm 0,37 \mathrm{mg}$ de $\mathrm{OEO} / \mathrm{mL}$, para $S$. aureus 
e E. coli, respectivamente. Os resultados mostram que não houve diferença significativa $(\mathrm{p}<$ 0,05) nas CIM e CBM para $S$. aureus e E. coli, indicando que as nanoemulsões NA-3,25 apresentaram potencial inibitório e bactericida semelhantes para a bactéria gram-positiva Staphylococcus aureus e a gram-negativa Escherichia coli.

Tabela 6. Concentração inibitória mínima (CIM) e concentração bactericida mínima (CBM) (mg de óleo essencial de orégano/mL), das nanoemulsões NA-3,25, para Staphylococcus aureus e Escherichia coli, durante o período de 90 dias de armazenamento.

\begin{tabular}{ccccccc}
\hline & Bactéria & Dia 1 & Dia 30 & Dia 60 & Dia 90 & Sig. \\
\hline CIM & S. aureus & $1,30 \pm 0,00^{2}$ & $1,95 \pm 0,65^{2}$ & $1,51 \pm 0,37^{2}$ & $1,08 \pm 0,37^{2}$ & n.s. \\
CBM & S. aureus & $3,67 \pm 0,37^{1}$ & $3,24 \pm 0,00^{1}$ & $3,67 \pm 0,37^{1}$ & $3,46 \pm 0,37^{1}$ & n.s. \\
CIM & E. coli & $1,73 \pm 0,37^{\mathrm{a}, \mathrm{b}, 2}$ & $1,73 \pm 0,37^{\mathrm{a}, \mathrm{b}, 2}$ & $2,59 \pm 0,65^{\mathrm{a}, 1,2}$ & $1,30 \pm 0,00^{\mathrm{b}, 2}$ & $*$ \\
CBM & E. coli & $3,46 \pm 0,37^{1}$ & $3,67 \pm 0,37^{1}$ & $3,89 \pm 0,65^{1}$ & $3,67 \pm 0,37^{1}$ & n.s. \\
Sig. & & $*$ & $*$ & $*$ & $*$ &
\end{tabular}

a-b - Médias seguidas com a mesma letra na mesma linha não se diferenciam ao nível de significância de $5 \%$, pelo teste de Tukey.

1-2 - Médias seguidas pelo mesmo número na mesma coluna não se diferenciam ao nível de significância de $5 \%$, pelo teste de Tukey.

Sig.= Significância: * significativo ao nível de $5 \%$ de probabilidade $(\mathrm{p}<0,05)$, n.s. não significativo ( $\mathrm{p}$ $>=0,05)$.

Fonte: Própria autoria.

Para as nanoemulsões NA-5, também não houve diferença significatica na CIM para $S$.

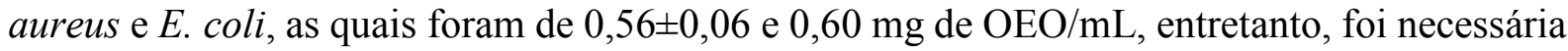
uma maior CBM para $E$. coli do que para $S$. aureus e, portanto, o potencial bactericida das nanoemulsões NA-5 foi superior para a bactéria gram-positiva. Em estudo realizado por Tassou, Koutsoumanis e Nychas (2010) as bactérias gram-positivas também foram mais sensíveis aos compostos fenólicos presentes nos óleos essenciais em comparação com bactérias gramnegativas. De acordo com Souza et al. (2010), esta maior atividade antibacteriana do OEO para S. aureus está associada à estrutura da parede celular, sendo que para bactérias gram-positivas, a estrutura celular permite maior acúmulo dos compostos de OE na membrana do citoplasma em relação as bactérias gram-negativas, como E. coli. Este acúmulo de óleo causa a perda de integridade do citoplama, tornando-o cada vez mais permeável aos prótons e íons, acarretando em danos irreversíveis às bactérias. 
Além disso, as bactérias gram-negativas apresentam resistência efetiva, pela permeabilidade da membrana celular, aos tensoativos das nanoemulsões devido à presença de grandes quantidades de lipopolissacarídeos (LPS) e proteínas, juntamente com pouco fosfolípido na membrana externa, tornando-a impermeável à macromoléculas e permitindo apenas a difusão limitada de substâncias hidrofóbicas, como o OEO, através de sua superfície coberta por LPS (NIXDORFF; GMEINER; MARTIN, 1978; VAARA, 1992; HAMOUDA; BAKER, 2000).

Tabela 7. Concentração inibitória mínima (CIM) e concentração bactericida mínima (CBM) (mg de óleo essencial de orégano/mL), das nanoemulsões NA-5, para Staphylococcus aureus e Escherichia coli, durante o período de 90 dias de armazenamento.

\begin{tabular}{ccccccc}
\hline & Bactéria & Dia 1 & Dia 30 & Dia 60 & Dia 90 & Sig. \\
\hline CIM & S. aureus & $0,56 \pm 0,06^{2}$ & $0,56 \pm 0,06^{2}$ & $0,43 \pm 0,06^{2}$ & $0,43 \pm 0,06^{2}$ & n.s. \\
CBM & S. aureus & $0,90 \pm 0,00^{2}$ & $0,86 \pm 0,06^{2}$ & $0,93 \pm 0,06^{2}$ & $0,93 \pm 0,06^{2}$ & n.s. \\
CIM & E. coli & $0,60 \pm 0,00^{2}$ & $0,60 \pm 0,00^{2}$ & $0,56 \pm 0,12^{2}$ & $0,47 \pm 0,06^{2}$ & n.s. \\
CBM & E. coli & $3,32 \pm 0,58^{1}$ & $3,99 \pm 1,00^{1}$ & $4,32 \pm 0,58^{1}$ & $4,65 \pm 0,58^{1}$ & n.s. \\
Sig. & & $*$ & $*$ & $*$ & $*$ &
\end{tabular}

1-2 - Médias seguidas pela mesmo número na mesma coluna não se diferenciam ao nível de significância de $5 \%$, pelo teste de Tukey.

Sig.= Significância: * significativo ao nível de $5 \%$ de probabilidade $(\mathrm{p}<0,05)$, n.s. não significativo ( $\mathrm{p}$ $>=0,05)$.

Fonte: Própria autoria.

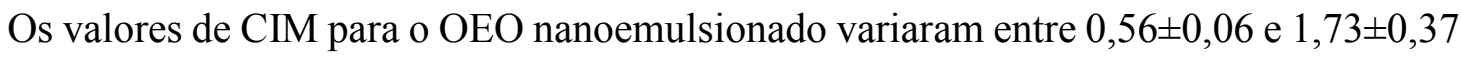
$\mathrm{mg}$ de $\mathrm{OEO} / \mathrm{mL}$ e estas concentrações foram semelhantes ou superiores aos valores de CIM do OEO não-emulsionado obtidos em alguns estudos (LAMBERT et al., 2001; BURT; REIDERS, 2003; SI et al., 2008; SOUZA et al., 2010). Portanto, as nanoemulsões não reduziram a atividade antibacteriana in vitro do $\mathrm{OE}$ conforme observado em estudos realizados por Anwer et al. (2014) e Moghimi et al. (2016a).

No entanto, alguns trabalhos também observaram que não houve alteração na atividade antimicrobiana de óleos essenciais quando foram emulsionados (CHANG; McLANDSBOROUGH; McCLEMENTS, 2012; XUE; DAVIDSON; ZHONG, 2015; ZIANI et al., 2011). Uma possível explicação para estas diferenças podem ser a incorporação de uma fase oleosa (neste caso o óleo de girassol), juntamente com os óleos essenciais no sistema 
nanoemulsionado, sendo que o óleo de girassol não possui ação antimicrobiana, mas, conforme o item 5.1.2, são usados para melhorar a estabilidade das emulsões por inibição da maturação de Ostwald. Entretanto a presença deste óleo pode reduzir a atividade antibacteriana da nanoemulsão in vitro atuando como solvente para os óleos essenciais e reduzindo assim a quantidade de OEO disponível para interagir com as bactérias (CHANG; McLANDSBOROUGH; McCLEMENTS, 2012; ZIANI et al., 2011; MOGHIMI et al. (2016a).

Os resultados observados nas Tabelas 6 e 7 ainda mostram que após 90 dias de armazenamento das nanoemulsões, não houve diferença significativa $(\mathrm{p}<0,05)$ nas CIM e CBM de ambas nanoemulsões para as bactérias testadas, ainda que não se tenha estudado a perda dos outros compostos presentes no OEO, presume-se que a perda com compostos voláteis (conforme descrito no item 5.2), não acarretou na redução do potencial antibacteriano das nanoemulsões encapsulando OEO ao longo do tempo, e portanto, a quantidade remanescente dos compostos foi suficiente para manter a atividade antibacteriana destas nanoemulsões.

As nanoemulsões NA-5, contendo os tensoativos Cremophor RH-40 e Span 80, apresentaram maior potencial na inibição da multiplicação de $S$. aureus e E. coli em relação as nanoemulsões NA3,25, pois os valores de CIM para as nanoemulsões NA-5 foram significativamente $(\mathrm{p}<0,05)$ menores. Ambas as nanoemulsões encapsularam o OEO do mesmo lote, entretanto, apresentam diferença em suas formulações em relação à quantidade de OEO de orégano adicionada $(3,25 \%(\mathrm{~m} / \mathrm{m})$ para NA-3,25 e $5 \%(\mathrm{~m} / \mathrm{m})$ para NA-5) e também ao tipo de tensoativos, que conferem diferença na sua estrutura e no tamanho de partículas. Portanto, esta diferença na ação antibacteriana entre as nanoemulsões está relacionada com a sua estrutura, uma vez que, segundo Hamouda et al. (2001), as estruturas das nanoemulsões desempenham um papel importante na sua função antibacteriana.

\subsection{Cinética da multiplicação bacteriana}

A cinética da multiplicação bacteriana foi determinada para verificar o comportamento das bactérias na presença das nanoemulsões durante um período de $72 \mathrm{~h}$. As curvas mostram que, na CIM, as nanoemulsões NA-3,25 e NA-5 reduziram a multiplicação, tanto para S. aureus quanto para E. coli em relação ao controle (sem antibiótico), durante o período de 72 horas de análise.

Para as nanoemulsões NA-3,25 (Figura 22), na curva de inibição da multiplicação de $S$. aureus, após 6 horas de incubação houve uma redução de 3 ciclos log na multiplicação da 
bactéria, mantendo-se constante até 72 horas. Para E. coli, também houve uma redução de 3 ciclos log após 6 horas de análise, porém, após 24 horas, houve um amento de 1 ciclo log na multiplicação bacteriana, que permaneceu constante até 72 horas. Apesar deste comportamento, verificou-se que houve uma redução na multiplicação bacteriana em relação à contaminação inicial das bactérias.

Figura 22. Curvas de multiplicação para $S$. aureus e E. coli: (ఐ) controle negativo (sem agente antibacteriano); ( $\mathbf{\Delta}$ ) nanoemulsão NA-3,25 na concentração inibitória mínima; e (४) controle positivo (antibiótico cloranfenicol: $1 \mathrm{mg} / \mathrm{ml}$ ).

S. aureus

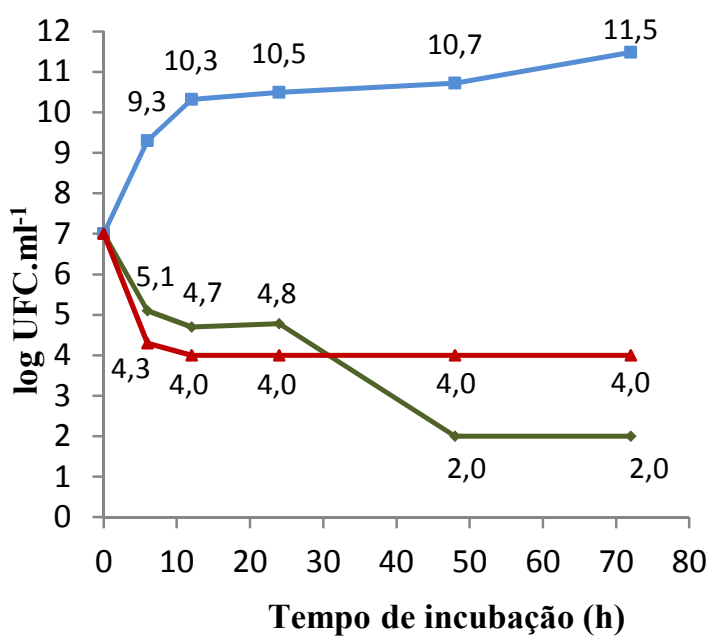

E. coli

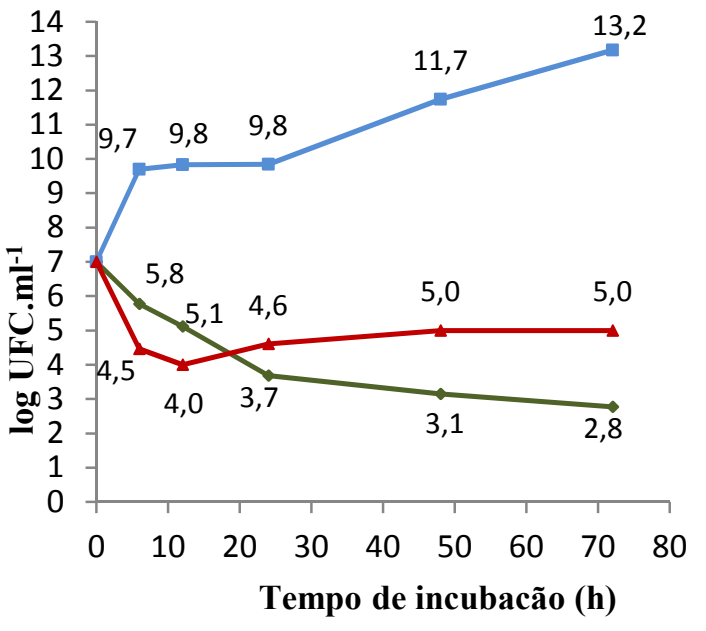

Fonte: Própria autoria.

Na Figura 23, a curva de inibição da multiplicação, para as bactérias S. aureus e E. coli, das nanoemulsões NA-5 demonstra que, após 72 horas, houve uma redução de 1 ciclo e 3 ciclos $\log$ para $S$. aureus e E. coli, respectivamente. Tal resultado indica que essa redução bacteriana pode estar relacionada com a liberação controlada de OEO pelas nanoemulsões durante o período analisado, uma vez que os sistemas nanoestruturados podem controlar a taxa de libertação do bioativo, neste caso o OEO, melhorando a disponibilidade do OEO ao longo do tempo, e além disso, as nanoemulsões podem proteger o bioativo contra degradação em condições desfavoráveis (FATHI; MOZAFARI; MOHEBBI, 2012). 
Figura 23. Curva de multiplicação para $S$. aureus e E. coli: (®) controle negativo (sem agente antibacteriano); ( $\mathbf{\Delta}$ ) nanoemulsão NA-5 na concentração inibitória mínima; e (\$) controle positivo (antibiótico cloranfenicol: $1 \mathrm{mg} / \mathrm{ml}$ ).

\section{S. aureus}

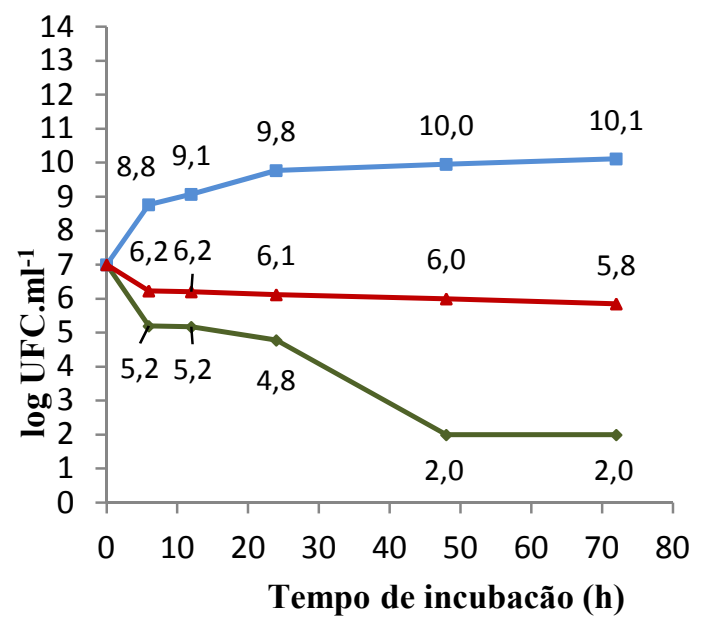

E. coli

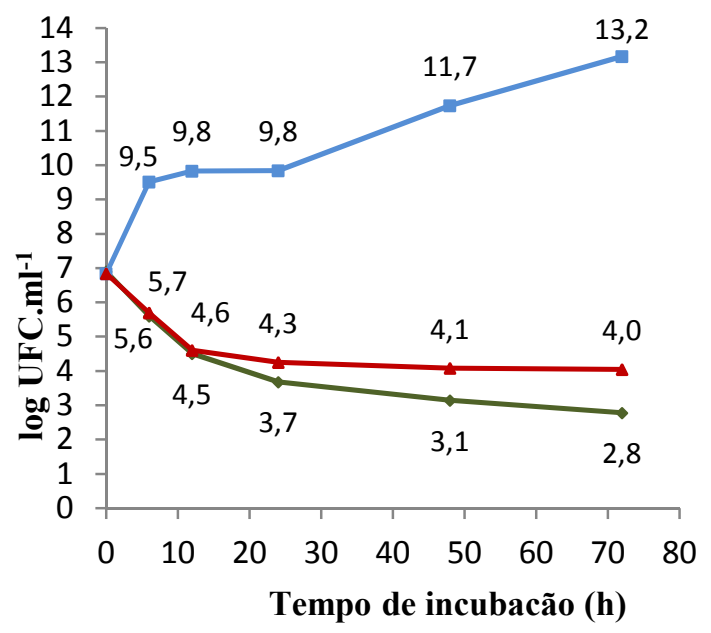

Fonte: Própria autoria.

\subsection{Capacidade antioxidante in vitro do OEO não-emulsionado}

De acordo com Kulisic et al. (2004), o efeito antioxidante do OEO é devido à presença dos compostos timol e carvacrol, mas os autores também sugerem um possível efeito sinérgico entre os compostos que contém oxigênio em sua molécula. Segundo Stamenic et al. (2014), baixos valores de IC50 correspondem a uma atividade antioxidante elevada. O OEO em estudo apresentou baixo valor de IC50 $(3,70 \mathrm{mg} / \mathrm{mL})$, o qual foi determinado utilizando-se o gráfico da Figura 24. Entretanto, vários estudos que avaliaram a atividade antioxidante do OEO, pela análise de $\mathrm{DPPH}^{\circ}$, relataram valores muito discrepantes entre si. Os valores de IC50 determinados por, Şahin et al. (2004), Kulisic et al. (2004), Babili et al. (2011) e Stamenic et al. (2014), foram de $8,9 \mathrm{mg} / \mathrm{mL}, 0,5 \mathrm{mg} / \mathrm{mL}, 0,06 \mathrm{mg} / \mathrm{mL}$ e $15,84 \mathrm{mg} / \mathrm{mL}$, respectivamente.

Os valores determinados para avaliar a atividade antioxidantes dos óleos essenciais variam muito entre os trabalhos uma vez que o poder antioxidante do OE depende da escolha do método de determinação da atividade antioxidante, da concentração utilizada nas análises e da composição química dos óleos essenciais (KOLEVA et al., 2002; KULISIC et al., 2004). 
Figura 24. Concentração de óleo essencial de orégano $(\mathrm{mg} / \mathrm{mL}) v s . \%$ redução dos radicais DPPH*

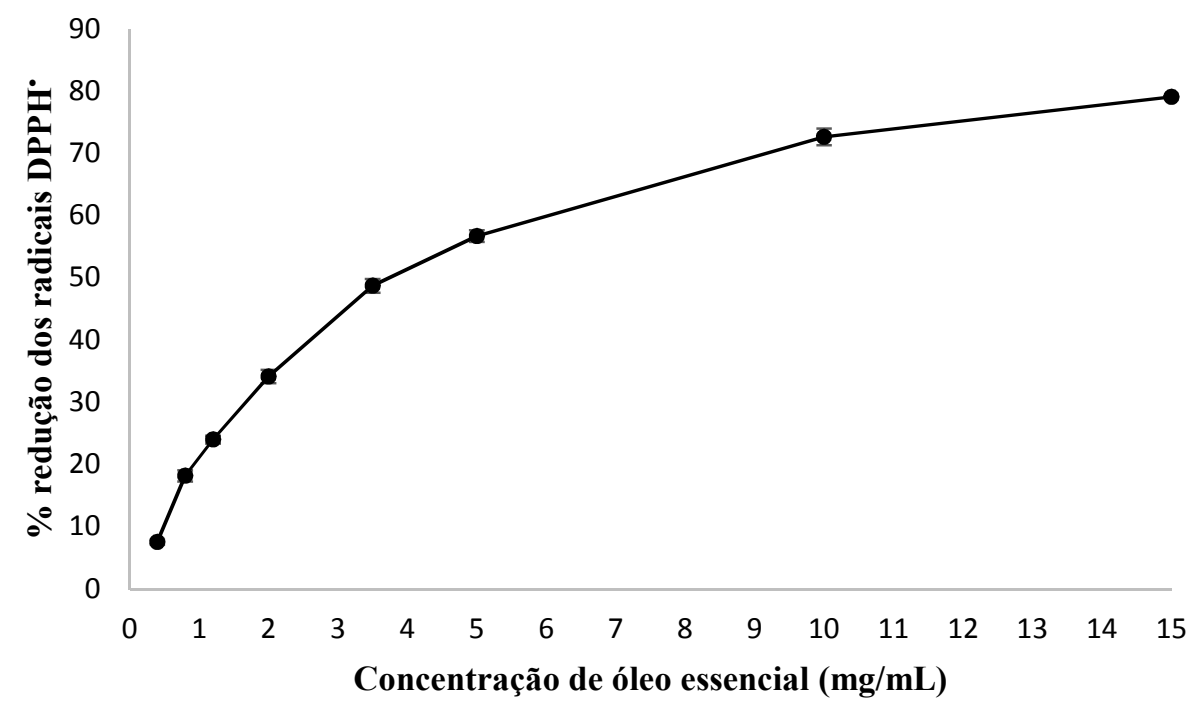

Fonte: Própria autoria.

\subsection{Avaliação da atividade antioxidante in vitro das nanoemulsões}

\subsubsection{Capacidade de redução dos radicais DPPH' das nanoemulsões durante o armazenamento}

Inicialmente, foi realizada a análise de porcentagem de redução de radicais $\mathrm{DPPH}^{\bullet}$ das nanoemulsões sem a adição de OEO, contendo apenas tensoativos, óleo de girassol e água. As análises mostraram que as nanoemulsões contendo os tensoativos Cremophor RH40 com Brij 30 e Cremophor RH40 com Span 80 apresentaram uma redução de 1,97 e 6,03 \%, respectivamente. Ao comparar com os valores das nanoemulsões após a adição do OEO, que foi de 63,4 e $71,8 \%$, respectivamente, pode-se afirmar que a atividade antioxidante das nanoemulsões está relacionada majoritariamente com o OEO, uma vez que as porcentagens de redução dos radicais $\mathrm{DPPH}^{\bullet}$ foram significativamente muito superiores aos valores das nanoemulsões sem adição deste óleo.

Na Figura 25, é possível observar que ambas as nanoemulsões apresentaram atividade antioxidante, sendo a porcentagem de redução dos radicais $\mathrm{DPPH}^{*}$ de $63,4 \%$ para as nanoemulsões NA-3,25 e 71,8 \% para as nanoemulsões NA-5. Entretanto, a redução de radicais DPPH $^{\bullet}$ das nanoemulsões contendo $5 \%$ de OEO (NA-5) foi significativamente maior que a nanoemulsão com 3,25 \% do óleo (NA-3,25), indicando que as nanoemulsões NA-5 
apresentaram maior atividade antioxidante em relação as nanoemulsões NA-3,25. As duas formulações de nanoemulsões variam entre si de acordo com a quantidade da fase oleosa (OEO e óleo de girassol) e tipo e quantidade de tensoativos, conforme a Tabela 3.

Joung et al. (2016) avaliaram o efeito da variação da concentração de óleo, tensoativo e água na atividade antioxidante das nanoemulsões encapsulando curcumina. Neste estudo, os autores observaram que não houve diferença significativa na capacidade antioxidante das nanoemulsões ao variar o teor de água; entretanto, a atividade antioxidante das nanoemulsões foi significativamente maior com aumento na concentração de tensoativo. Segundo os referidos autores, tal resultado indica que uma concentração mais elevada de tensoativo poderia facilitar a dissolução da curcumina na fase oleosa, conduzindo a uma maior atividade antioxidante. Por este motivo, concluiu-se que as concentrações de óleo e tensoativo afetam a atividade antioxidante das nanoemulsões por influenciar na solubilidade do antioxidante (curcumina). Portanto, o aumento significativo na atividade antioxidante das nanoemulsões NA-5 pode estar associado com o maior teor de tensoativos $(20 \%)$ e OEO $(5 \%)$ em relação às nanoemulsões NA-3,25, que apresentam em sua formulação $13 \%$ de tensoativos e 3,25 \% de OEO.

Segundo Richards et al. (2002), os tensoativos também podem influenciar na localização dos antioxidantes nas emulsões óleo/água pela solubilização de antioxidantes lipossolúveis na fase aquosa. Os autores relatam que geralmente os antioxidantes não polares, como o OEO, que são encapsulados nas gotículas de emulsão, apresentam maior eficiência antioxidante do que os antioxidantes polares que têm uma partição significativa na fase contínua de uma emulsão de O/A, e tal partição é influenciada pelas suas características moleculares, como polaridade, peso molecular e atividade superficial.

As nanoemulsões NA-3,25 e NA-5 apresentaram uma diminuição significativa do potencial de redução dos radicais $\mathrm{DPPH}^{*}$ a partir da semana 13 de armazenamento. A Figura 25 mostra que ao longo de 24 semanas de armazenamento, as nanoemulsões NA-3 apresentaram uma redução dos radicais DPPH $^{\bullet}$ de 41,2 \% e as nanoemulsões NA-5 mostraram uma redução de $54,3 \%$. 
Figura 25. Porcentagem de redução dos radicais $\mathrm{DPPH}^{\bullet}$ durante o período de 24 semanas de armazenamento das nanoemulsões sob refrigeração: $(\bullet)$ nanoemulsões NA-3,25 (com 3,25\% de OEO) e (匹) nanoemulsões NA-5 (com $5 \%$ de OEO).

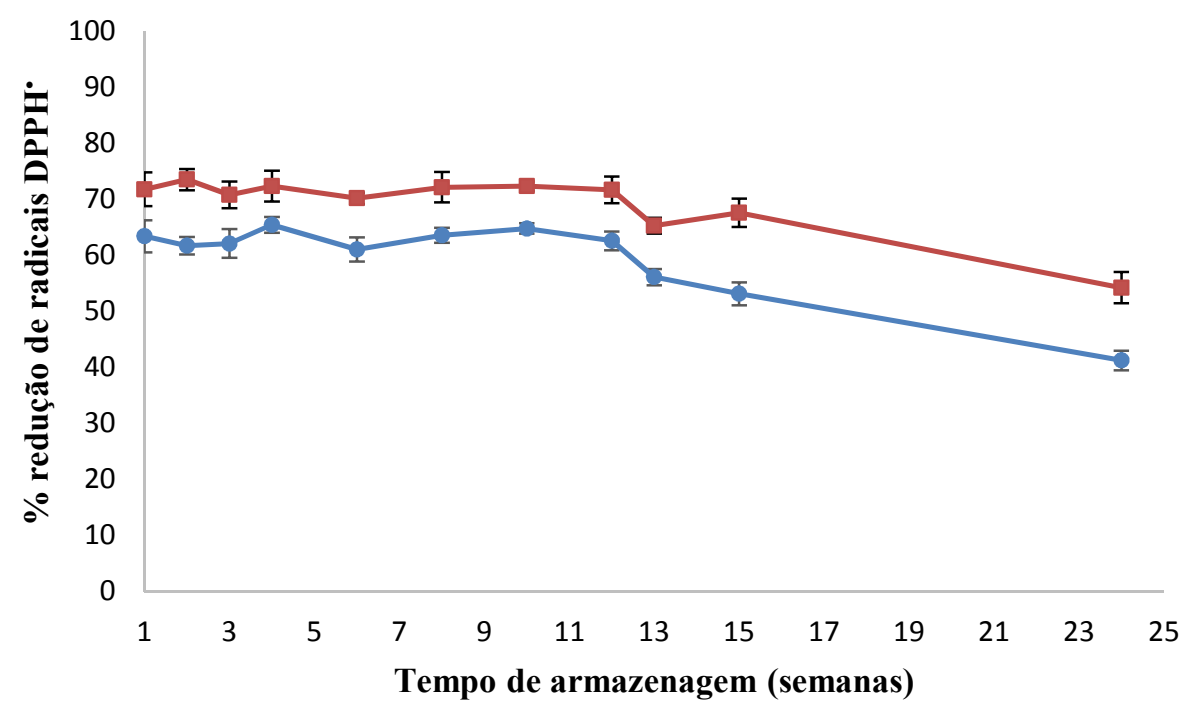

Fonte: Própria autoria.

\subsubsection{Determinação do teor de fenólicos totais das nanoemulsões durante o armazenamento}

A quantificação dos fenólicos totais também foi realizada com as amostras de nanoemulsões com e sem a adição de OEO. As nanoemulsões que apresentavam em sua composição os tensoativos Cremophor RH40 com Brij 30 e Cremophor RH40 com Span 80 obtiveram um valor de $0,002 \pm 0,001$ e $0,005 \pm 0,001 \mathrm{mg}$ equivalente de ácido gálico. $\mathrm{mL}^{-1}$, respectivamente, enquanto que após a adição do OEO, esses valores foram de 10,1 $\pm 0,79$ e 16,8 $\pm 3,6 \mathrm{mg}$ equivalente de ácido gálico. $\mathrm{mL}^{-1}$. A partir desses resultados pode-se atribuir a capacidade antioxidante das nanoemulsões ao OEO adicionado e não aos outros componentes constituintes das nanoemulsões.

Ha et al. (2015) estudaram a capacidade antioxidante das nanoemulsões encapsulando extrato de tomate enriquecido com licopeno e observaram que as nanoemulsões foram eficientes em proteger atividade antioxidante do carotenoide; entretanto, eles não avaliaram a atividade antioxidante das nanoemulsões ao longo do tempo. A Figura 26 mostra que não houve 
diferença significativa nos valores de fenólicos totais durante as 24 semanas de armazenamento das nanoemulsões. Portanto, a redução de atividade antioxidante observada pela porcentagem de inibição dos radicais $\mathrm{DPPH}^{\bullet}$ (item 5.6.1) não está relacionada com o teor de fenólicos totais das nanoemulsões.

Valores significativamente maiores do teor de fenólicos totais para as nanoemulsões NA-5 (com $5 \%$ de OEO) em relação as nanoemulsões NA-3,25 (com 3,25 \% de OEO), conforme a Figura 26, estão relacionados com a maior concentração de OEO presente nas nanoemulsões NA-5, uma vez que este óleo é rico em compostos fenólicos.

Figura 26. Quantificação do teor de fenólicos totais durante o período de 24 semanas de armazenamento das nanoemulsões sob refrigeração: (•) nanoemulsões NA-3,25 (com 3,25\% de OEO) e (ロ) nanoemulsões NA-5 (com $5 \%$ de OEO).

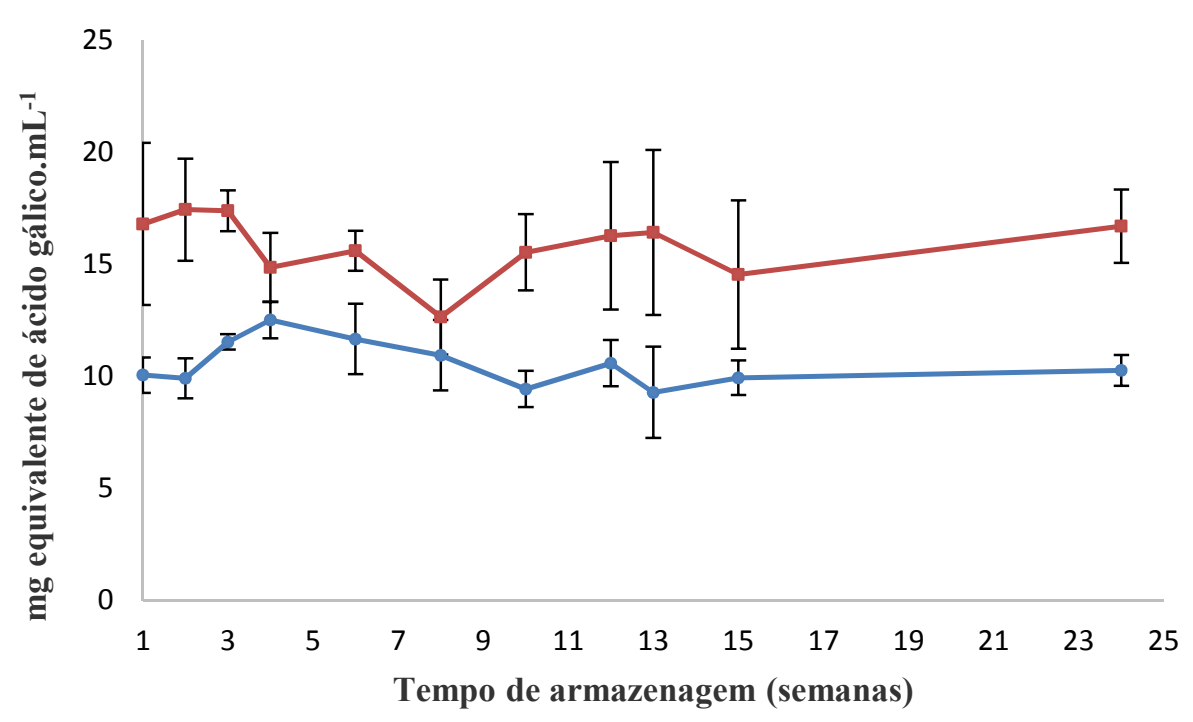

Fonte: Própria autoria.

\subsection{Caracterização físico-química do patê de frango: composição centesimal}

A composição centesimal das amostras de patê de frango foi realizada para verificar se o produto produzido estava de acordo com os parâmetros determinados pela legislação brasileira para este tipo de alimento, os quais são determinados pelo regulamento técnico de 
identidade e qualidade de patê descrito na Instrução Normativa $n^{\circ} 21$, de 31 de julho de 2000 (BRASIL, 2000).

Os resultados de umidade, proteína, lipídios e cinzas (Tabela 8), obtidos para todos os tratamentos do patê frango, mostram que o produto cárneo obtido está de acordo com as características estabelecidas pela legislação brasileira (Brasil, 2000), o qual determina que o teor máximo de umidade e lipídios deve ser de 70 e $32 \%$, respectivamente, e para proteína bruta, no mínimo $8 \%$. De acordo com a Tabela 8 , os resultados mostram que o patê de frango em estudo apresenta características e propriedades nutricionais adequadas para este tipo de alimento, conforme a legislação brasileira.

Tabela 8. Composição centesimal do patê de frango. Tratamentos: T1: sem antioxidantes e conservantes, T2: adição de $0,06 \%(\mathrm{~m} / \mathrm{m})$ de óleo essencial de orégano não-emulsionado, T3: adição de $6 \%(\mathrm{~m} / \mathrm{m})$ das nanoemulsões NA-3,25, T4: adição de $1,2 \%(\mathrm{~m} / \mathrm{m})$ das nanoemulsões NA-5 e T5: adição de BHT e nitrito de sódio.

\begin{tabular}{ccccc}
\hline \multirow{2}{*}{ Tratamento } & \multicolumn{4}{c}{ Composição centesimal (\%) } \\
\cline { 2 - 5 } & Umidade & Proteína & Lipídios & Cinzas \\
\hline T1 & $36,8 \pm 0,01^{\mathrm{b}}$ & $31,1 \pm 0,17$ & $15,3 \pm 1,72$ & $6,0 \pm 0,04^{\mathrm{b}}$ \\
T2 & $36,7 \pm 0,11^{\mathrm{b}}$ & $32,1 \pm 0,41$ & $13,9 \pm 2,70$ & $6,0 \pm 0,01^{\mathrm{b}}$ \\
T3 & $37,2 \pm 0,04^{\mathrm{a}}$ & $31,5 \pm 0,08$ & $16,5 \pm 0,11$ & $5,8 \pm 0,04^{\mathrm{c}}$ \\
T4 & $36,8 \pm 0,04^{\mathrm{b}}$ & $32,1 \pm 0,00$ & $15,50,61$ & $6,0 \pm 0,03^{\mathrm{b}}$ \\
T5 & $36,8 \pm 0,12^{\mathrm{b}}$ & $32,3 \pm 0,10$ & $14,6 \pm 1,36$ & $6,2 \pm 0,02^{\mathrm{a}}$ \\
Sig. & $*$ & n.s. & n.s. & $*$
\end{tabular}

Legislação** Máximo $70 \%$ Mínimo $8 \%$ Máximo $32 \%$

a-c - Médias seguidas com a mesma letra na mesma coluna não se diferenciam ao nível de significância de $5 \%$, pelo teste de Tukey.

Sig.= Significância: * significativo ao nível de $5 \%$ de probabilidade, n.s. não significativo $(\mathrm{p}>=0,05)$.

Legislação** - Instrução Normativa n ${ }^{\circ} 21$ de 31 de julho de 2000 (BRASIL, 2000).

Fonte: Própria autoria. 
Entretanto, valores diferentes de umidade, proteína e lipídios foram encontrados em trabalhos realizados com patê. Estévez, Ventanas e Cava (2006) e Delgado-Pando et al. (2011) realizaram estudos com patê de fígado suíno, sendo que os primeiros autores obtiveram valores de umidade, proteínas e lipídios variando entre 48-49 \%, 9,8-10,3 \% e 32-33\%, respectivamente, e o segundo trabalho apresentou estes valores variando entre 50,08-66,18\%, para umidade, 13,06-14,46 \% para proteínas e 15,13-30,79 \% para lipídios. Em um estudo realizado por Pereira (2015), a qual estudou a aplicação de microcápsulas de coprodutos de suco e vinho de uva em patê de frango, os teores de umidade, proteínas e lipídios apresentaram variação entre os tratamentos de: $57,18-57,65 \%, 9,17-9,51 \%$ e $17,74-18,11 \%$, respectivamente.

Segundo Pereira (2015), diferentes valores de composição centesimal encontrados em diversos estudos de patê estão relacionados com fatores que podem influenciar a sua composição físico-química, mesmo que a matéria-prima dos estudos seja da mesma espécie, uma vez que a composição química das carnes e gorduras de espécies animais é diretamente afetada pela genética, nutrição e idade do animal e teor de gordura, sendo que, além disso, outros fatores também podem interferir nas característica do produto cárneo, como o tipo de preparo e processamento e a adição dos ingredientes, os quais na maioria das vezes diferem muito entre os trabalhos.

Em relação a umidade, T3 apresentou valor significativamente maior $(p<0,05)$ em relação aos demais tratamentos aos quais foram adicionados OEO não-emulsionado, 1,2 \% $(\mathrm{m} / \mathrm{m})$ de nanoemulsões NA-5, e nitrito de sódio e BHT. Tal fato está relacionado com a quantidade de nanoemulsões NA-3,25 adicionada no T3 $(6 \% \mathrm{~m} / \mathrm{m})$, a qual foi superior aos demais tratamentos, e, como consequência, pelo fato das nanoemulsões apresentarem como fase contínua a água, o teor de umidade foi superior. Entretanto, para os teores de proteínas e lipídios, não houve diferença significativa entre os tratamentos, indicando que os aditivos adicionados nos tratamentos não influenciaram nestas características do produto.

Para o teor de cinzas, o qual está relacionado com a quantidade de material inorgânico presente no alimento, a legislação brasileira (BRASIL, 2000) não estabelece um valor limite em patê. Não foram encontradas referências no teor de cinzas para patê de frango especificamente, porém, Lorenzo e Pateiro (2013), obtiveram um teor de cinzas variando entre 3,25 e 3,26\% para patê de fígado de cavalo, Echarte et al. (2004) determinou um teor de cinzas entre 2,21 e 2,72 para patê de fígado de porco, 2,37 para patê de salmão, 5,02 para patê de 
anchova e 2,54 para patê de bacalhau. Segundo Echarte et al. (2004), estes tipos de alimentos são considerados como uma boa fonte de minerais (matéria inorgânica) e o elevado teor de cinzas, observado neste estudo. pode estar relacionado com a quantidade de sal $(\mathrm{NaCl})$ adicionada na formulação do patê de frango e também com a perda de água da carne e do fígado durante o cozimento no processamento do produto cárneo.

\subsection{Avaliação da qualidade microbiológica do patê de frango}

As análises de contagem de micro-organismos viáveis totais, bactérias aeróbias psicrotróficas e das enterobactérias realizadas nas amostras de patê de frango submetidas aos 5 tratamentos, mostraram que não houve multiplicação microbiana até o período de 60 dias de armazenamento. Nas análises realizadas no dia 90 de armazenamento das amostras refrigeradas, observou-se a ausência de bactérias aeróbias psicrotróficas e das enterobactérias, entretanto, houve a presença de colônias características de leveduras (Figura 27) nas análises de contagem de micro-organismos viáveis totais para todos os tratamentos do patê de frango, indicando que, após 90 de armazenamento, o produto não apresentava qualidade microbiológicas adequadas para consumo.

Figura 27. Presença de colônias de levedura, pela análise microbiológica de contagem de microorganismos viáveis totais, no dia 90 de armazenamento das amostras de patê de frango. Da esquerda para direita: T4 (com adição de nanoemulsões NA-5) e T5 (adição de BHT e nitrito de sódio).

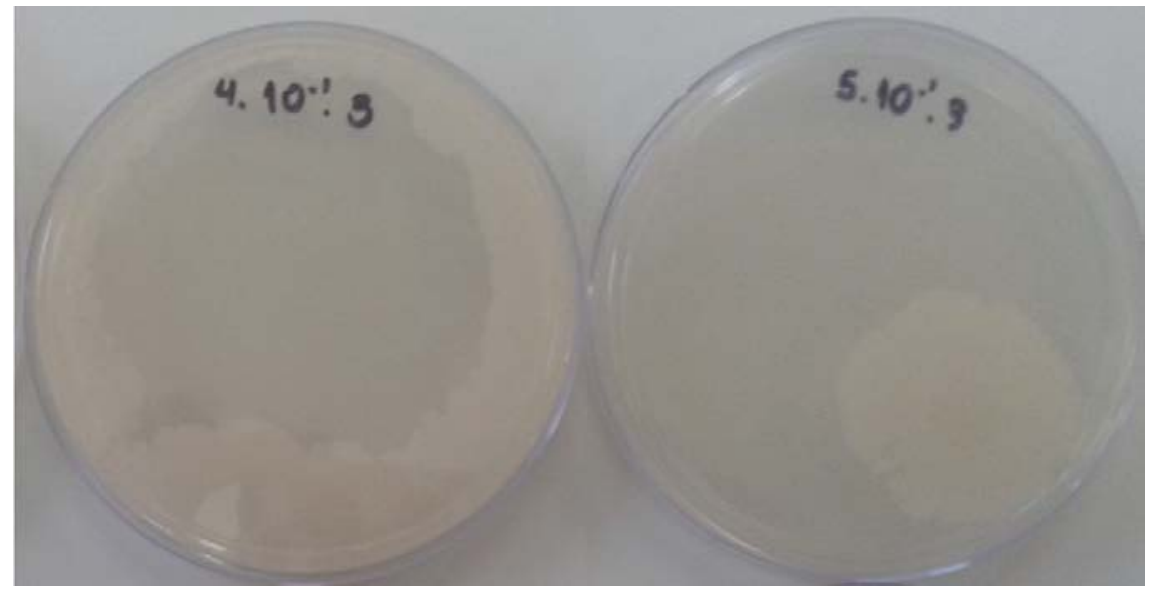

Fonte: Própria autoria. 
Os patês de frango comerciais apresentam vida de prateleira variando entre 45 e 60 dias. Portanto, a vida de prateleira do patê produzido neste trabalho, que foi de 60 dias, está de acordo com o tempo esperado para este tipo de produto, e a boa qualidade microbiológica deste produto cárneo está associada ao tratamento térmico (pasteurização) eficiente durante a processamento.

\subsection{Atividade antibacteriana das nanoemulsões no patê de frango}

A contaminação experimental padronizada das amostras de patê de frango com as bactérias $S$. aureus e E.coli foram realizadas para simular a contaminação do patê após aberto, visto que após aberta a embalagem, a vida de prateleira deste produto é muito curta (aproximadamente 4 dias).

Para S. aureus (Figura 28), T1 e T2, tratamentos sem conservantes e com OEO nãoemulsionado, respectivamente, não apresentaram redução significativa da contaminação bacteriana após o período de 8 dias da contaminação. Entretanto, T3 e T5, contendo as nanoemulsões NA-3,25 e nitrito de sódio, respectivamente, foram os tratamentos com maior potencial de ação contra $S$. aureus, apresentando redução de 1 ciclo log após 8 dias em relação a contaminação inicial. O tratamento T4, contendo nanoemulsão com $5 \%$ de $\mathrm{OEO}$, apresentou uma redução significativa da contaminação, porém, esta redução foi menor em relação aos T3 e T5.

Figura 28. Curvas de inibição da multiplicação de $S$. aureus durante o período de 8 dias, após a contaminação experimental das amostras. ( $)$ T1: sem antioxidantes e conservantes, (๕) T2: adição de $0,06 \%(\mathrm{~m} / \mathrm{m})$ de óleo essencial de orégano não-emulsionado, $(\Delta)$ T3: adição de $6 \%(\mathrm{~m} / \mathrm{m})$ das nanoemulsões NA-3,25, $(\times)$ T4: adição de 1,2 \% (m/m) das nanoemulsões NA-5 e (○) T5: adição de BHT e nitrito de sódio.

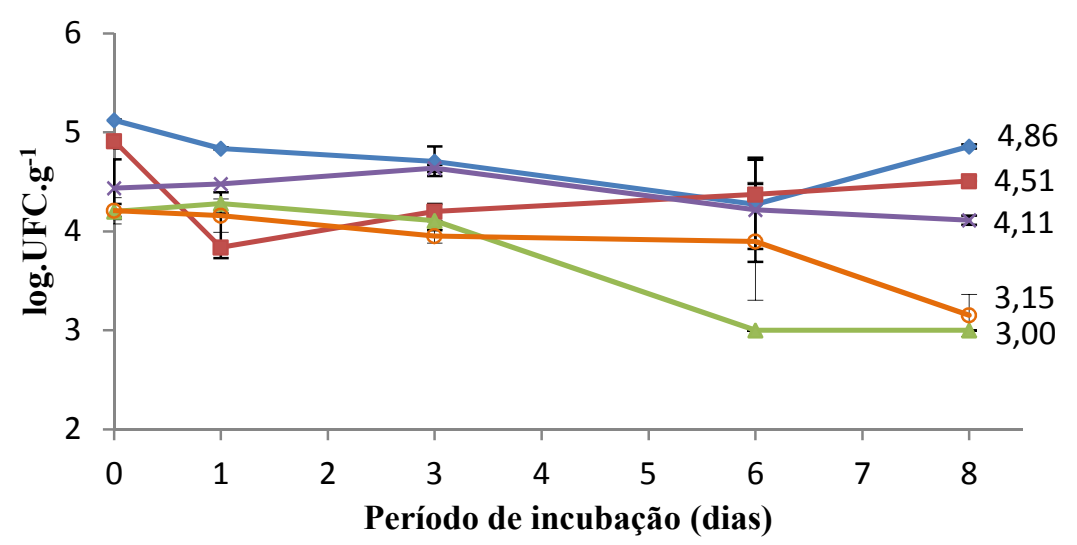

Fonte: Própria autoria. 
As análises microbiológicas realizadas para E. coli, conforme a Figura 29, mostram que após 8 dias da contaminação inicial das amostras de patê de frango, apenas os tratamentos T3 e T4, contendo nanoemulsões NA-3,25 e NA-5, respectivamente, apresentaram redução de 3 e 2 ciclos $\log$, respectivamente. Esta diferença observada na redução da multiplicação bacteriana para T3 e T4 está relacionada com o maior teor de OEO adicionado no T3 $(0,2 \% \mathrm{~m} / \mathrm{m})$ em relação ao T4 $(0,06 \%$ m/m).

Figura 29. Curvas de inibição da multiplicação de $E$. coli, durante o período de 8 dias, após a contaminação experimental das amostras. ( $\bullet$ T1: sem antioxidantes e conservantes, ( $\bullet$ ) T2: adição de $0,06 \%(\mathrm{~m} / \mathrm{m})$ de óleo essencial de orégano não-emulsionado, $(\triangle)$ T3: adição de $6 \%(\mathrm{~m} / \mathrm{m})$ das nanoemulsões NA-3,25, $(\times)$ T4: adição de $1,2 \%(\mathrm{~m} / \mathrm{m})$ das nanoemulsões NA-5 e $(\circ)$ T5: adição de BHT e nitrito de sódio.

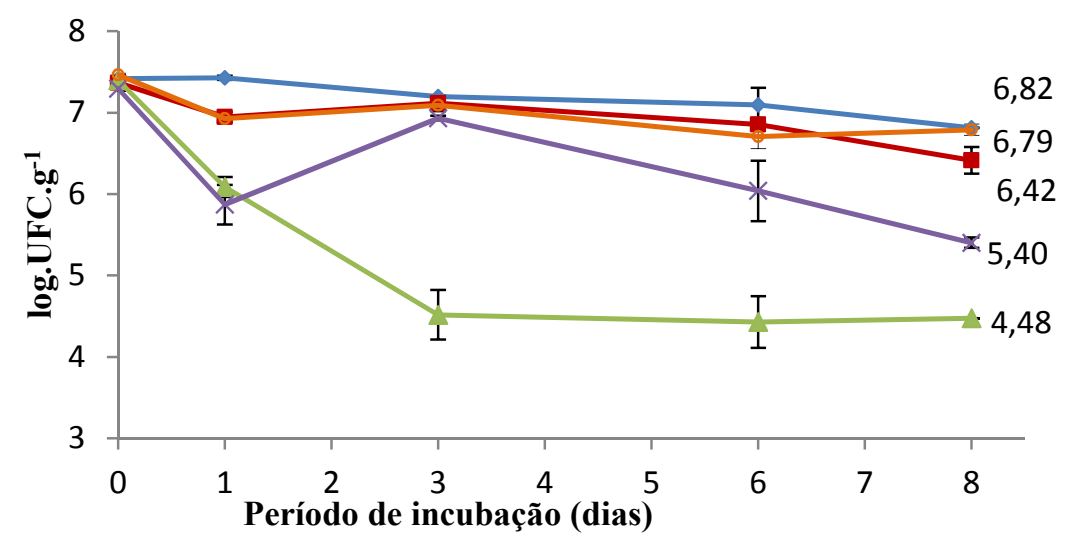

Fonte: Própria autoria.

Entretanto, resultados diferentes da atividade antibacteriana in vitro (item 5.3) foram observados no patê de frango, pois para ambas as bactérias o OEO nanoemulsionado apresentou maior potencial antibacteriano do que o OE não-emulsionado. Negi (2012) supõe que o nível de conservantes naturais, como o $\mathrm{OE}$ não-emulsionado, podem ser consideravelmente mais elevados nos produtos alimentares do que in vitro devido aos multicomponentes presentes nos alimentos que podem interferir na interação do agente antibacteriano com as bactérias.

Segundo Moghimi et al. (2016b), este comportamento no produto alimentar está associado ao pequeno tamanho de gotas das nanoemulsões, que pode aumentar as interações entre os compostos ativos com as membranas das bactérias, bem como a sua transferência através delas. Além disso, a interação dos óleos essenciais puros com os componentes do alimento, como lipídios e proteínas, pode influenciar na eficiência dos antimicrobianos e, 
portanto, alterar a multiplicação microbiana (GUTIERREZ; BARRY-RYAN; BOURKE, 2008; WEISS; LOEFFLER; TERJUNG, 2015). Weiss, Loeffler e Terjung (2015) atribuíram a redução da atividade antimicrobiana dos óleos essenciais ao conteúdo protéico do sistema alimentar, sugerindo que os grupos fenólicos do OE se ligam à proteína, diminuindo assim a quantidade de composto antimicrobiano disponível para inibição da multiplicação bacteriana. Portanto, além do tamanho de gota das nanoemulsões também pode-se associar a maior atividade antibacteriana do OEO nanoemulsionado no patê de frango, com a proteção do OEO pela estrutura das nanoemulsões, contra a interação com os componentes do alimento.

Entretanto, neste estudo, a concentração mínima de OEO nanoemulsionada, para inibir a multiplicação das bactérias $S$. aureus e E. coli, determinada in vitro também foi suficiente para inibir a multiplicação destas bactérias no patê de frango.

\subsection{Estabilidade físico-química do patê de frango durante o armazenamento}

A estabilidades físico-química das amostras de patê de frango, submetidas aos 5 tratamentos, foi determinada pela: mensuração do $\mathrm{pH}$, análise dos parâmetros de cor e avaliação da oxidação lipídica e proteica durante o período de 16 semanas de armazanemamento do patê de frango sob armazenamento. Estas análises foram realizadas com a finalidade de verificar a influência do OEO não-emulsionado e nanoemulsionado na estabilidade deste produto cárneo.

\section{10.1 Aferição de pH}

$\mathrm{O} \mathrm{pH}$ das amostras de patê de frango em estudo (Figura 30) foi inferior ao encontrado na literatura, como por exemplo, Estévez, Ventana e Cava (2005) obtiveram valores de pH variando entre 6,34 e 6,39, e Pateiro et al. (2014) de 6,16 a 6,34, ambos para patê de fígado de porco. Os baixos valores de $\mathrm{pH}$ estão relacionados com a acidificação do produto cárneo, durante o processamento, para evitar a multiplicação bacteriana, uma vez que não foi adicionado nitrito de sódio em todos os tratamentos para evitar sua influência na atividade antioxidante do OEO nanoemulsionado.

Após 16 semanas de armazenamento (Figura 30), foi possível observar um aumento significativo $(\mathrm{p}<0,05)$ nos valores de $\mathrm{pH}$, em relação a primeira semana, para todos os tratamentos de patê de frango. Além disso, T1 (sem adição de antioxidantes e conservantes), 
apresentou valor de $\mathrm{pH}$ significativamente $(\mathrm{p}<0,05)$ menor em relação aos demais tratamentos após 16 semanas de armazenamento.

Figura 30. Resultados de $\mathrm{pH}$ das amostras de patê de frango durante o período de 16 semanas de armazenamento sob refrigeração. Tratamentos: ( $\downarrow$ ) T1: sem antioxidantes e conservantes, (घ) T2: adição de $0,06 \%(\mathrm{~m} / \mathrm{m})$ de óleo essencial de orégano não-emulsionado, $(\Delta)$ T3: adição de $6 \%(\mathrm{~m} / \mathrm{m})$ das nanoemulsões NA-3,25, (×) T4: adição de 1,2 \% (m/m) das nanoemulsões NA-5 e (०) T5: adição de BHT e nitrito de sódio.

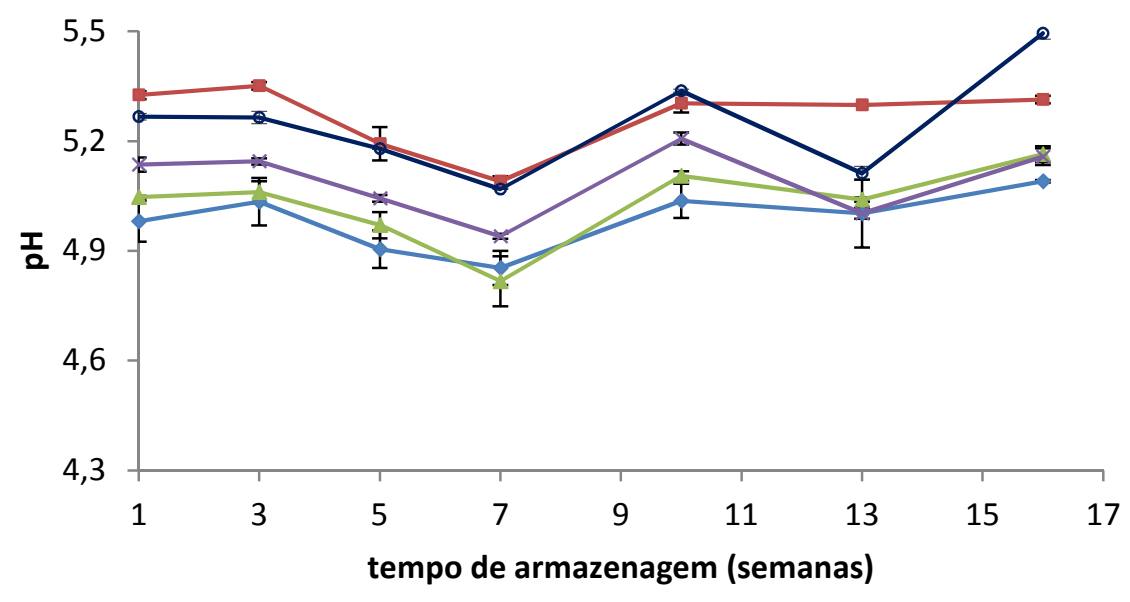

Fonte: Própria autoria.

\subsubsection{Determinação dos parâmetros colorimétricos}

$\mathrm{Na}$ primeira semana de análise, os valores dos parâmetros de cor $\mathrm{L}^{*} \mathrm{e} \mathrm{b}^{*}$ não apresentaram variação significativa $(\mathrm{p}<0,05)$ entre todos os tratamentos, indicando que o OEO não emulsionado, as nanoemulsões e o antioxidante BHT não afetaram estes parâmetros. $\mathrm{Na}$ análise do parâmetro a*, o aumento significativo para o tratamento com nitrito de sódio (T5), em relação aos demais tratamentos, ocorreu devido à coloração rósea que o nitrito de sódio confere aos produtos cárneos, presevando assim o teor de vermelho da amostra. Segundo Doolaege et al. (2012), o desenvolvimento da cor típica dos produtos curados à base de carne é o mais importante efeito do nitrito de sódio.

A Tabela 9 mostra que a variável Croma $\left(\mathrm{C}^{*}\right)$ não apresentou variação significativa entre os tratamentos durante o armazenamento, sendo que ao avaliar os valores de $C^{*}$ para cada tratamento ao longo do tempo, foi possível observar que apenas o tratamento 4 apresentou uma redução significativa na semana 16. Para o ângulo Hue $\left(\mathrm{H}^{*}\right)$, houve um aumento significativo para todos os tratamentos no fim do período de armazenamento (16 semanas), e de acordo com 
Lee et al. (2005), o aumento no valor de $\mathrm{H}^{*}$ ao longo do tempo indica um processo de descoloração do produto cárneo. Estévez e Cava (2004) e Estévez e Cava (2006) sugerem que esta degradação de cor observada ao longo do armazenamento pode ser influenciada pela oxidação proteica do produto cárneo. O mesmo pôde ser observado neste estudo, uma vez que todos os tratamentos sofreram oxidação proteica durante o armazenamento (de acordo com o item 5.10.3), o que poderia justificar a descoloração de todas as amostras de patê de frango, incluindo o tratamento com o antioxidante sintético BHT.

$\mathrm{Na}$ diferença total de cor $(\Delta \mathrm{E})$ entre o início (semana 1) e o final do período de armazenamento (semana 16), os tratamentos contendo OEO não-emulsionado, nanoemulsões NA-5 e BHT e nitrito de sódio (T2, T4 e T5, respectivamente) apresentaram valores superiores ao tratamento controle sem antioxidantes; entretanto, pode-se considerar que, de fato, tal aumento não foi significativo. $\mathrm{O}$ mesmo fato também foi relatado em um estudo realizado por Estévez, Ventanas e Cava (2006) em patê de fígado de porco, que apresentaram um valor de $\Delta \mathrm{E}$, entre os dias 0 e 90, superiores para os tratamentos com BHT e óleos essenciais de sálvia e alecrim, em relação ao controle sem antioxidante (BHT: 5,45; sálvia: 5,34, alecrim: 4,49 e controle: 3,38). Estes autores associaram a alteração de cor com mudanças químicas ou na composição do patê de fígado de porco, que podem ter ocorrido durante o armazenamento, e que não estão, necessariamente, diretamente relacionados com processos oxidativos. Portanto, assim como observado por estes autores, a descoloração do patê de frango em estudo também pode estar associada com as alterações químicas e na composição do produto ao longo do tempo.

Além disso, todos os tratamentos apresentaram valores de $\Delta \mathrm{E}_{1-16}$ superiores a 2 , conforme mostrado na Tabela 9, que é o limite determinado por Francis e Clydesdale (1975) para detecção visual de alteração de cor. 
Tabela 9. Valores de $L^{*}, a^{*}, b^{*}$, Croma $\left(C^{*}\right)$, ângulo Hue $\left(H^{*}\right)$ e diferença total de cor $(\Delta E)$ durante o armazenamento (16 semanas).

\begin{tabular}{|c|c|c|c|c|c|c|c|c|}
\hline & \multirow[b]{2}{*}{$\mathrm{T}$} & \multicolumn{7}{|c|}{ Tempo de armazenamento (semanas) } \\
\hline & & 1 & 3 & 5 & 7 & 10 & 13 & 16 \\
\hline \multirow[t]{6}{*}{$\mathrm{L}^{*}$} & $\mathrm{~T} 1$ & $54,07 \pm 1,28^{\mathrm{a}}$ & $53,15 \pm 3,4^{\mathrm{a}}$ & $58,14 \pm 1,19^{\mathrm{a}, 1}$ & $57,66 \pm 0,88^{\mathrm{a}, 1}$ & $41,82 \pm 0,54^{\mathrm{b}, 1,2}$ & $53,98 \pm 0,59^{\mathrm{a}}$ & $53,12 \pm 3,48^{\mathrm{a}}$ \\
\hline & $\mathrm{T} 2$ & $54,52 \pm 0,74^{\mathrm{b}, \mathrm{c}}$ & $53,40 \pm 0,92^{\mathrm{c}}$ & $56,55 \pm 0,36^{\mathrm{a}, \mathrm{b}, 1,2}$ & $57,50 \pm 0,59^{\mathrm{a}, 1,2}$ & $41,96 \pm 0,06^{\mathrm{d}, 1,2}$ & $53,99 \pm 0,70^{\mathrm{b}, \mathrm{c}}$ & $52,74 \pm 2,14^{\mathrm{c}}$ \\
\hline & $\mathrm{T} 3$ & $53,26 \pm 0,22^{b}$ & $53,15 \pm 0,49^{b}$ & $55,43 \pm 1,23^{\mathrm{a}, \mathrm{b}, 2}$ & $56,83 \pm 0,27^{\mathrm{a}, 1,2}$ & $41,15 \pm 0,28^{\mathrm{c}, 2}$ & $53,26 \pm 2,66^{\mathrm{b}}$ & $54,76 \pm 0,72^{\mathrm{a}, \mathrm{b}}$ \\
\hline & $\mathrm{T} 4$ & $53,89 \pm 1,53^{\mathrm{a}, \mathrm{b}}$ & $52,35 \pm 1,81^{\mathrm{b}}$ & $56,77 \pm 1,21^{\mathrm{a}, 1,2}$ & $56,91 \pm 0,36^{\mathrm{c}, 1,2}$ & $43,05 \pm 1,31^{\mathrm{a}, \mathrm{b}, 1,2}$ & $54,51 \pm 0,64^{\mathrm{a}, \mathrm{b}}$ & $54,81 \pm 0,26^{\mathrm{a}, \mathrm{b}}$ \\
\hline & $\mathrm{T} 5$ & $53,42 \pm 0,14^{\mathrm{b}}$ & $51,94 \pm 1,31^{\mathrm{b}}$ & $55,44 \pm 0,36^{\mathrm{a}, 2}$ & $56,19 \pm 0,23^{\mathrm{c}, 2}$ & $41,67 \pm 0,60^{\mathrm{b}, 1,2}$ & $52,81 \pm 0,67^{\mathrm{b}}$ & $52,91 \pm 0,56^{\mathrm{b}}$ \\
\hline & Sig. & n.s. & n.s. & $*$ & $*$ & $*$ & n.s. & n.s. \\
\hline \multirow[t]{6}{*}{$a^{*}$} & $\mathrm{~T} 1$ & $1,18 \pm 0,30^{\mathrm{b}, 2}$ & $1,68 \pm 0,23^{\mathrm{a}, \mathrm{b}, 2}$ & $1,67 \pm 0,14^{\mathrm{a}, \mathrm{b}, 2}$ & $1,65 \pm 0,18^{\mathrm{a}, \mathrm{b}, 2}$ & $1,79 \pm 0,17^{\mathrm{a}, 1}$ & $1,22 \pm 0,25^{\mathrm{b}, 1,2}$ & $-0,05 \pm 0,11^{\mathrm{c}}$ \\
\hline & $\mathrm{T} 2$ & $1,11 \pm 0,39^{\mathrm{a}, 2}$ & $0,09 \pm 0,09^{\mathrm{b}, 3}$ & $0,47 \pm 0,05^{\mathrm{b}, 4}$ & $0,34 \pm 0,09^{\mathrm{b}, 3}$ & $0.39 \pm 0,17^{\mathrm{b}, 2}$ & $0,24 \pm 0,07^{\mathrm{b}, 3}$ & $-0,04 \pm 0,13^{b}$ \\
\hline & $\mathrm{T} 3$ & $0,87 \pm 0,07^{\mathrm{b}, \mathrm{c}, 2}$ & $0,70 \pm 0,24^{\mathrm{c}, 3}$ & $1,24 \pm 0,18^{\mathrm{a}, \mathrm{b}, 3}$ & $1,21 \pm 0,10^{\mathrm{a}, \mathrm{b}, 2}$ & $1,51 \pm 0,07^{\mathrm{a}, 1}$ & $1,10 \pm 0,18^{\mathrm{b}, 2}$ & $-0,12 \pm 0,03^{\mathrm{d}}$ \\
\hline & $\mathrm{T} 4$ & $0,82 \pm 0,23^{\mathrm{c}, 2}$ & $0,94 \pm 0,33^{\mathrm{b}, \mathrm{c}, 2,3}$ & $1,43 \pm 0,08^{\mathrm{a}, \mathrm{b}, 2,3}$ & $1,36 \pm 0,20^{\mathrm{a}, \mathrm{b}, 2}$ & $1,51 \pm 0,08^{\mathrm{a}, 1}$ & $1,40 \pm 0,17^{\mathrm{a}, \mathrm{b}, 1,2}$ & $0,04 \pm 0,20^{\mathrm{d}}$ \\
\hline & $\mathrm{T} 5$ & $4,07 \pm 0,41^{\mathrm{a}, 1}$ & $3,52 \pm 0,56^{\mathrm{a}, 1}$ & $3,63 \pm 0,11^{\mathrm{a}, 1}$ & $2,66 \pm 0,24^{\mathrm{b}, 1}$ & $1,72 \pm 0,22^{\mathrm{b}, 1}$ & $1,62 \pm 0,07^{b, 1}$ & $0,17 \pm 0,12^{\mathrm{c}}$ \\
\hline & Sig. & $*$ & $*$ & $*$ & $*$ & $*$ & $*$ & n.s. \\
\hline \multirow[t]{6}{*}{$b^{*}$} & $\mathrm{~T} 1$ & $14,84 \pm 0,72^{\mathrm{a}, \mathrm{b}}$ & $15,38 \pm 0,44^{\mathrm{a}}$ & $14,86 \pm 0,07^{\mathrm{a}, \mathrm{b}}$ & $16,13 \pm 0,67^{\mathrm{a}}$ & $12,71 \pm 0,42^{\mathrm{c}}$ & $14,69 \pm 0,82^{\mathrm{a}, \mathrm{b}}$ & $13,64 \pm 0,80^{\mathrm{b}, \mathrm{c}}$ \\
\hline & $\mathrm{T} 2$ & $15,28 \pm 0,68^{\mathrm{a}}$ & $15,90 \pm 0,73 \mathrm{a}$ & $15,41 \pm 0,17^{\mathrm{a}}$ & $15,72 \pm 0,48^{\mathrm{a}}$ & $12,93 \pm 0,11^{\mathrm{b}}$ & $15,16 \pm 0,16^{\mathrm{a}}$ & $14,52 \pm 0,91^{\mathrm{a}}$ \\
\hline & $\mathrm{T} 3$ & $14,89 \pm 0,11^{\mathrm{a}}$ & $15,81 \pm 0,95^{\mathrm{a}}$ & $15,04 \pm 0,14^{\mathrm{a}}$ & $15,68 \pm 0,47^{\mathrm{a}}$ & $12,77 \pm 0,03^{b}$ & $14,42 \pm 0,71^{\mathrm{a}}$ & $14,37 \pm 0,71^{\mathrm{a}}$ \\
\hline & $\mathrm{T} 4$ & $15,64 \pm 0,83^{\mathrm{a}}$ & $16,55 \pm 0,43^{\mathrm{a}}$ & $15,16 \pm 0,71^{\mathrm{a}, \mathrm{b}}$ & $16,01 \pm 0,15^{\mathrm{a}}$ & $12,50 \pm 0,57^{\mathrm{c}}$ & $15,36 \pm 0,37^{\mathrm{a}}$ & $13,78 \pm 0,20^{\mathrm{b}, \mathrm{c}}$ \\
\hline & $\mathrm{T} 5$ & $15,34 \pm 0,44^{\mathrm{a}}$ & $15,32 \pm 0,69^{\mathrm{a}}$ & $15,07 \pm 0,48^{\mathrm{a}}$ & $15,59 \pm 0,31^{\mathrm{a}}$ & $12,84 \pm 0,10^{\mathrm{b}}$ & $15,68 \pm 0,35^{\mathrm{a}}$ & $15,10 \pm 0,27^{\mathrm{a}}$ \\
\hline & Sig. & n.s. & n.s. & n.s. & n.s. & n.s. & n.s. & n.s. \\
\hline \multirow[t]{6}{*}{$\mathrm{C}^{*}$} & $\mathrm{~T} 1$ & $14,89 \pm 0,72^{\mathrm{a}, \mathrm{b}}$ & $15,47 \pm 0,45^{\mathrm{a}}$ & $14,96 \pm 0,07 \mathrm{a}, \mathrm{b}$ & $16,21 \pm 0,65^{a}$ & $12,84 \pm 0,42^{\mathrm{c}}$ & $14,74 \pm 0,83^{\mathrm{a}, \mathrm{b}}$ & $13,64 \pm 0,80^{\mathrm{b}, \mathrm{c}}$ \\
\hline & $\mathrm{T} 2$ & $15,33 \pm 0,70^{\mathrm{a}}$ & $15,90 \pm 0,7^{\mathrm{a}}$ & $15,42 \pm 0,17^{\mathrm{a}}$ & $15,73 \pm 0,48^{\mathrm{a}}$ & $12,93 \pm 0,11^{b}$ & $15,16 \pm 0,16^{\mathrm{a}}$ & $14,52 \pm 0,91^{\mathrm{a}}$ \\
\hline & $\mathrm{T} 3$ & $14,91 \pm 0,11^{\mathrm{a}}$ & $15,82 \pm 0,95^{\mathrm{a}}$ & $15,09 \pm 0,15^{\mathrm{a}}$ & $15,73 \pm 0,48^{\mathrm{a}}$ & $12,86 \pm 0,03^{\mathrm{b}}$ & $14,47 \pm 0,72^{\mathrm{a}}$ & $14,37 \pm 0,71^{\mathrm{a}, \mathrm{b}}$ \\
\hline & $\mathrm{T} 4$ & $15,67 \pm 0,81^{\mathrm{a}}$ & $16,58 \pm 0,44^{\mathrm{a}}$ & $15,22 \pm 0,70^{\mathrm{a}}$ & $16,07 \pm 0,14^{\mathrm{a}}$ & $12,59 \pm 0,56^{b}$ & $15,43 \pm 0,38^{\mathrm{a}}$ & $13,78 \pm 0,20^{\mathrm{b}}$ \\
\hline & $\mathrm{T} 5$ & $15,87 \pm 0,49^{\mathrm{a}}$ & $15,73 \pm 0,56^{\mathrm{a}}$ & $15,50 \pm 0,45^{\mathrm{a}}$ & $15,82 \pm 0,27^{\mathrm{a}}$ & $12,96 \pm 0,10^{\mathrm{b}}$ & $15,76 \pm 0,36^{\mathrm{a}}$ & $15,10 \pm 0,27^{\mathrm{a}}$ \\
\hline & Sig. & n.s. & n.s. & n.s. & n.s. & n.s. & n.s. & n.s. \\
\hline \multirow[t]{6}{*}{$\mathrm{H}^{*}$} & $\mathrm{~T} 1$ & $85,41 \pm 1,12^{\mathrm{b}, 1}$ & $83,74 \pm 0,77^{\mathrm{b}, \mathrm{c}, 2}$ & $83,53 \pm 0,55^{\mathrm{b}, \mathrm{c}, 3}$ & $84,10 \pm 0,78^{\mathrm{b}, 2}$ & $81,91 \pm 0,83^{\mathrm{c}, 2}$ & $85,22 \pm 0,67^{\mathrm{b}, 2,3}$ & $89,54 \pm 0,17^{\mathrm{a}}$ \\
\hline & $\mathrm{T} 2$ & $85,85 \pm 1,23^{\mathrm{b}, 1}$ & $89,62 \pm 0,30^{\mathrm{a}, 1}$ & $88,19 \pm 0,19^{\mathrm{a}, 1}$ & $88,72 \pm 0,32^{\mathrm{a}, 1}$ & $88,23 \pm 0,77^{\mathrm{a}, 1}$ & $89,05 \pm 0,26^{\mathrm{a}, 1}$ & $89,56 \pm 0,26^{\mathrm{a}}$ \\
\hline & $\mathrm{T} 3$ & $86,62 \pm 0,26^{\mathrm{b}, \mathrm{c}, 1}$ & $87,41 \pm 0,85^{\text {b, } 1}$ & $85,23 \pm 0,66^{\mathrm{d}, 2}$ & $83,55 \pm 0,24^{\mathrm{c}, \mathrm{d}, 2}$ & $83,21 \pm 0,34^{\mathrm{e}, 2}$ & $85,59 \pm 0,52^{\mathrm{c}, \mathrm{d}, 2}$ & $89,47 \pm 0,13^{\mathrm{a}}$ \\
\hline & $\mathrm{T} 4$ & $86,93 \pm 0,98^{\mathrm{b}, 1}$ & $86,72 \pm 1,05^{\mathrm{b}, \mathrm{c}, 1,2}$ & $85,55 \pm 0,54^{\mathrm{d}, \mathrm{e}, 2,3}$ & $85,08 \pm 0,75^{\mathrm{b}, \mathrm{c}, \mathrm{d}, 2}$ & $83,02 \pm 0,61^{\mathrm{e}, 2}$ & $84,74 \pm 0,52^{\mathrm{d}, \mathrm{e}, 2,3}$ & $89,31 \pm 0,36^{\mathrm{a}}$ \\
\hline & $\mathrm{T} 5$ & $75,09 \pm 1,28^{\mathrm{d}, 2}$ & $76,94 \pm 2,50^{\mathrm{c}, \mathrm{d}, 3}$ & $76,41 \pm 0,73^{\mathrm{d}, 4}$ & $80,25 \pm 1,05^{\mathrm{b}, \mathrm{c}, 3}$ & $82,33 \pm 0,95^{\mathrm{b}, 2}$ & $84,04 \pm 0,13^{\mathrm{b}, 3}$ & $89,30 \pm 0,45^{\mathrm{a}}$ \\
\hline & Sig. & $*$ & $*$ & $*$ & $*$ & $*$ & $*$ & n.s. \\
\hline \multirow[t]{6}{*}{$\Delta \mathrm{E}$} & $\mathrm{T} 1$ & & & & & & & $2,59 \pm 0,43$ \\
\hline & $\mathrm{T} 2$ & & & & & & & $2,73 \pm 0,39$ \\
\hline & $\mathrm{T} 3$ & & & & & & & $2,48 \pm 0,58$ \\
\hline & $\mathrm{T} 4$ & & & & & & & $4,05 \pm 1,33$ \\
\hline & $\mathrm{T} 5$ & & & & & & & $3,67 \pm 0,56$ \\
\hline & Sig. & & & & & & & n.s. \\
\hline
\end{tabular}




\subsubsection{Oxidação proteica: quantificação do teor de carbonilas totais}

A oxidação das proteínas presentes no patê de frango foi avaliada pela quantificação de carbonilas totais, pois de acordo com Stadtman e Levine (2003), o desenvolvimento de reações oxidativas em produtos alimentícios à base de carne leva à degradação de aminoácidos essenciais, e à posterior formação de ligações cruzadas bem como de carbonilas proteicas. A quantificação do teor de carbonilas foi realizada para verificar se as nanoemulsões encapsulando OEO seriam capazes de inibir ou retardar a oxidação proteica no patê de frango.

Na primeira semana, o teor de carbonilas variou entre 0,87 e 1,54 nM carbonila/mg de proteína (Figura 31) entre os tratamentos, e durante o armazenamento de 16 semanas, foi possível observar que para todos os tratamentos houve um aumento significativo no teor de carbonilas em relação à semana 1 . Um comportamento semelhante foi observado em um estudo realizado por Estévez, Ventana e Cava (2006), que avaliaram o efeito dos antioxidantes naturais de sálvia e alecrim na oxidação proteica de patê de fígado de porco sobre armazenamento refrigerado. No citado trabalho, a quantidade de carbonilas aumentou significativamente tanto para os tratamentos com sálvia e alecrim quanto para o controle (sem antioxidantes) e o antioxidante sintético BHT, no período de 60 para 90 dias de armazenamento.

Lorenzo et al. (2014b) associaram a oxidação proteica de patê ao longo do tempo com a trituração da carne durante a homogeneização e com as temperaturas aplicadas no tratamento térmico, durante a fabricação do patê. Segundo esses autores, o aquecimento degrada a mioglobina, causando a libertação de ferro e aumentando o seu potencial pró-oxidante em carnes cozidas. Por outro lado, a ruptura dos tecidos, durante a homegenização do produto, leva à libertação de pró-oxidantes naturalmente presentes no músculo da carne, aumentando a incorporação de oxigênio no sistema, facilitando assim, a oxidação do produto cárneo.

Segundo Jongberg et al. (2013) a inibição da formação de carbonilas proteicas após a adição de compostos antioxidantes fenólicos não é sempre observado, sendo que vários estudos mostram nenhum efeito pró-oxidativo de extratos de plantas ricas em compostos fenólicos (como o OEO) sobre a formação de carbonilas durante a produção e após o tratamento térmico de produtos cárneos. Os mesmos autores ainda relacionam o efeito de proteção à oxidação proteica com a dependência da composição da matéria-prima (tanto em relação ao tipo de carne quanto ao tipo de antioxidante), bem como com as concentrações de antioxidantes empregadas e com as tecnologias de produção do produto cárneo. 
Figura 31. Valores médios de carbonilas das amostras de patê de frango durante 16 semanas de armazenamento sob refrigeração. Tratamentos: ( $)$ T1: sem antioxidantes e conservantes, ( $($ ) T2: adição de $0,06 \%(\mathrm{~m} / \mathrm{m})$ de óleo essencial de orégano não-emulsionado, $(\Delta)$ T3: adição de $6 \%(\mathrm{~m} / \mathrm{m})$ das nanoemulsões NA-3,25, (×) T4: adição de 1,2 \% (m/m) das nanoemulsões NA-5 e (०) T5: adição de BHT e nitrito de sódio.

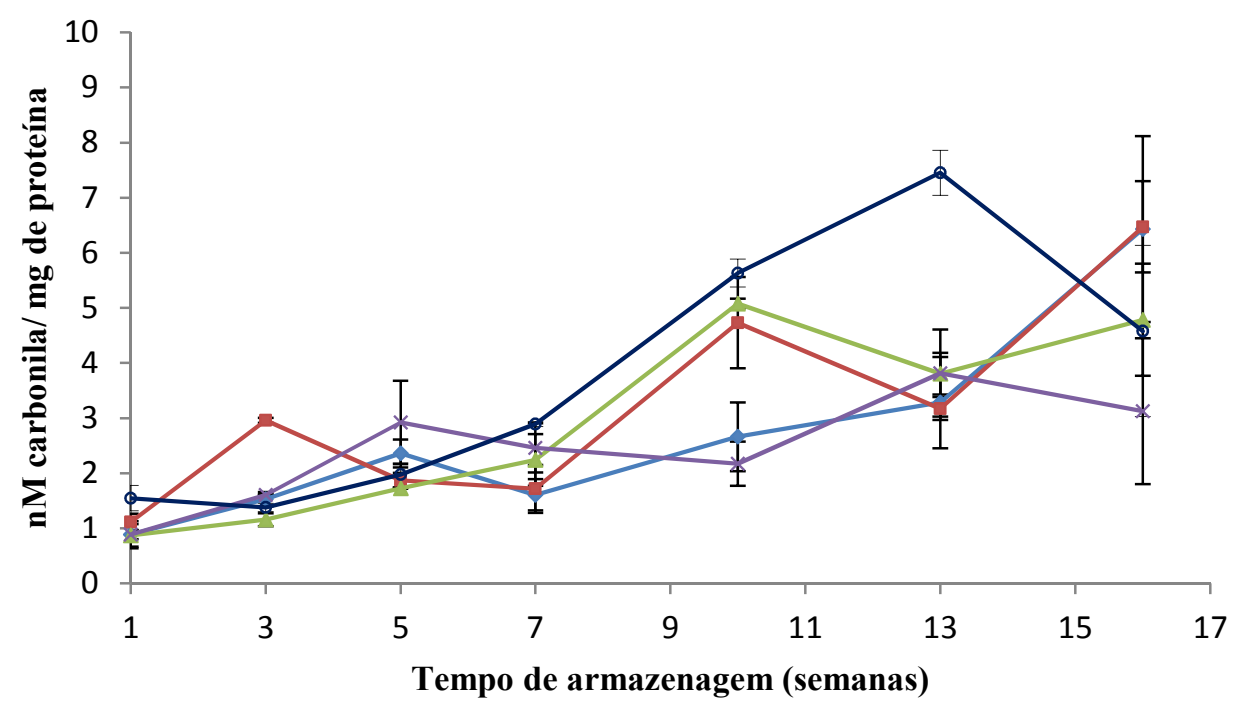

Fonte: Própria autoria.

\subsubsection{Oxidação lipídica: índice de peróxido e substâncias reativas ao ácido tiobarbitúrico (TBARS)}

Os valores do índice de peróxido para todos os tratamentos, na primeira semana de armazenamento, não apresentaram diferença significativa entre si $(\mathrm{p}<0,05)$, indicando que a adição das nanoemulsões não afetou na estabilidade oxidativa no início do armazenamento. Segundo Morrissey et al. (1998), a formação dos peróxidos se inicia durante o processamento e o tratamento térmico do patê, o que justifica a presença de peróxido nas amostras de patê de frango nos dias iniciais de armazenamento, que variou entre 0,88 e 1,05 meq $\mathrm{O}_{2} / \mathrm{kg}$ de amostra, conforme mostrado na Figura 32.

Para todos os tratamentos, houve um aumento no índice de peróxido no início do armazenamento (até a semana 5), e posteriormente, uma redução significativa nestes valores, conforme Figura 32. Este comportamento, segundo Akarpat, Turhan e Ustun (2008), ocorre devido a auto-oxidação dos lipídios que compõem o produto, sendo que nas primeiras etapas a 
taxa de formação dos hidroperóxidos é superior à sua taxa de decomposição. O inverso ocorre na fase posterior, sendo que nesta fase os hidroperóxidos começam a se decompor mais rapidamente à medida em que são formados.

Figura 32. Valores médios de índice de peróxido das amostras de patê de frango durante 16 semanas de armazenamento sob refrigeração. Tratamentos: ( $\downarrow$ ) T1: sem antioxidantes e conservantes, (๘) T2: adição de $0,06 \%(\mathrm{~m} / \mathrm{m})$ de óleo essencial de orégano não-emulsionado, $(\triangle)$ T3: adição de $6 \%(\mathrm{~m} / \mathrm{m})$ das nanoemulsões NA-3,25, $(\times)$ T4: adição de 1,2 \% (m/m) das nanoemulsões NA-5 e (০) T5: adição de BHT e nitrito de sódio.

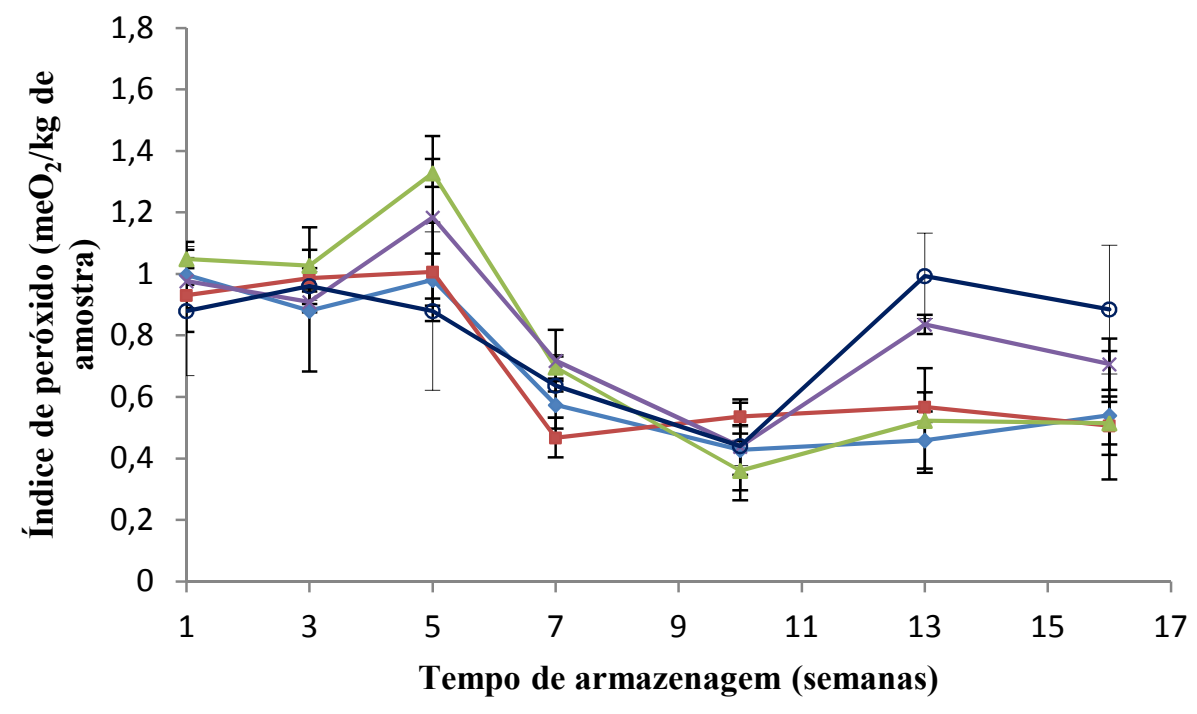

Fonte: Própria autoria.

Uma redução do índice de peróxido durante o armazenamento também foi observada por Pateiro et al. (2014), que estudou o efeito antioxidante do chá verde, castanha e extrato de uva em patê de fígado de porco. Neste estudo, a quantidade de peróxidos diminuiu gradativamente durante o armazenamento refrigerado por 24 semanas e os autores relacionaram tal queda com a decomposição destes compostos em produtos de oxidação secundários.

Apesar da redução significativa $(p<0,05)$ nos valores de índice de peróxido, que foi observado na semana 10 de armazenamento, e que está relacionada com a instabilidade desses produtos primários, que se decompõe para gerar produtos secundários (BOSELLI et al., 2005), não houve, durante este período de 10 semanas, um aumento significativo dos valores de TBARS (Tabela 10), os quais são indicativos de oxidação secundária. Com isso, sugere-se que 
os hidroperóxidos podem ter sido degradados em compostos que não podem ser detectados na análise de TBARS, como cetonas, álcoois, aldeídos (exceto malonaldeído), hidrocarbonetos e ácidos orgânicos voláteis ou epóxi (SHAHIDI e ZHONG, 2010).

Os valores de TBARS (Tabela 10), mostram que na semana 16 houve um aumento significativo para todos os tratamentos em relação à semana 1. Entretanto, ao comparar os valores entre os tratamentos na semana 16, foi possível observar que as amostras de patê de frango sem antioxidantes e conservantes, as quais representam T1, apresentou valor de TBARS significativamente maiores em relação aos demais tratamentos. A \% de inibição da oxidação lipídica dos tratamentos em relação ao controle (T1-sem antioxidantes), na semana 16 de armazenamento, para tratamentos com adição de OEO não-emulsionado, das nanoemulsões NA-3,25, das nanoemulsões NA-5 e de BHT e nitrito de sódio foram de: 30,37 \%, 41,89 \%, $46,40 \%$ e 36,24 \%, respectivamente. Este resultado indica que as nanoemulsões NA-3,25 e NA-5 apresentaram atividade antioxidante superior ao antioxidante sintético BHT, o qual é amplamente empregado na indústria de produtos cárneos.

Resultados semelhantes foram obtidos por Estévez et al. (2007), o qual avaliou a atividade antioxidante de óleos essenciais de sálvia e alecrim vs BHT em patê de fígado suíno e obteve uma \% de inibição da oxidação lipídica, após 90 dias, para sálvia (48,22 \%) e alecrim $(52,50 \%)$ muito superiores a \% de inibição do antioxidante sintético BHT (27, 95 \%), indicando a alta eficácia de óleos essenciais contra reações oxidativas. 
Tabela 10. Valores médios de substâncias reativas ao ácido tiobarbitúrico (TBARS) durantes 16 semanas de armazenamento. Tratamentos: T1: sem antioxidantes e conservantes, T2: adição de $0,06 \%$ $(\mathrm{m} / \mathrm{m})$ OEO livre, T3: adição de $6 \%(\mathrm{~m} / \mathrm{m})$ das nanoemulsões NA-3,25, T4: adição de 1,2 \% $(\mathrm{m} / \mathrm{m})$ das nanoemulsões NA-5 e T5: adição de BHT e nitrito de sódio.

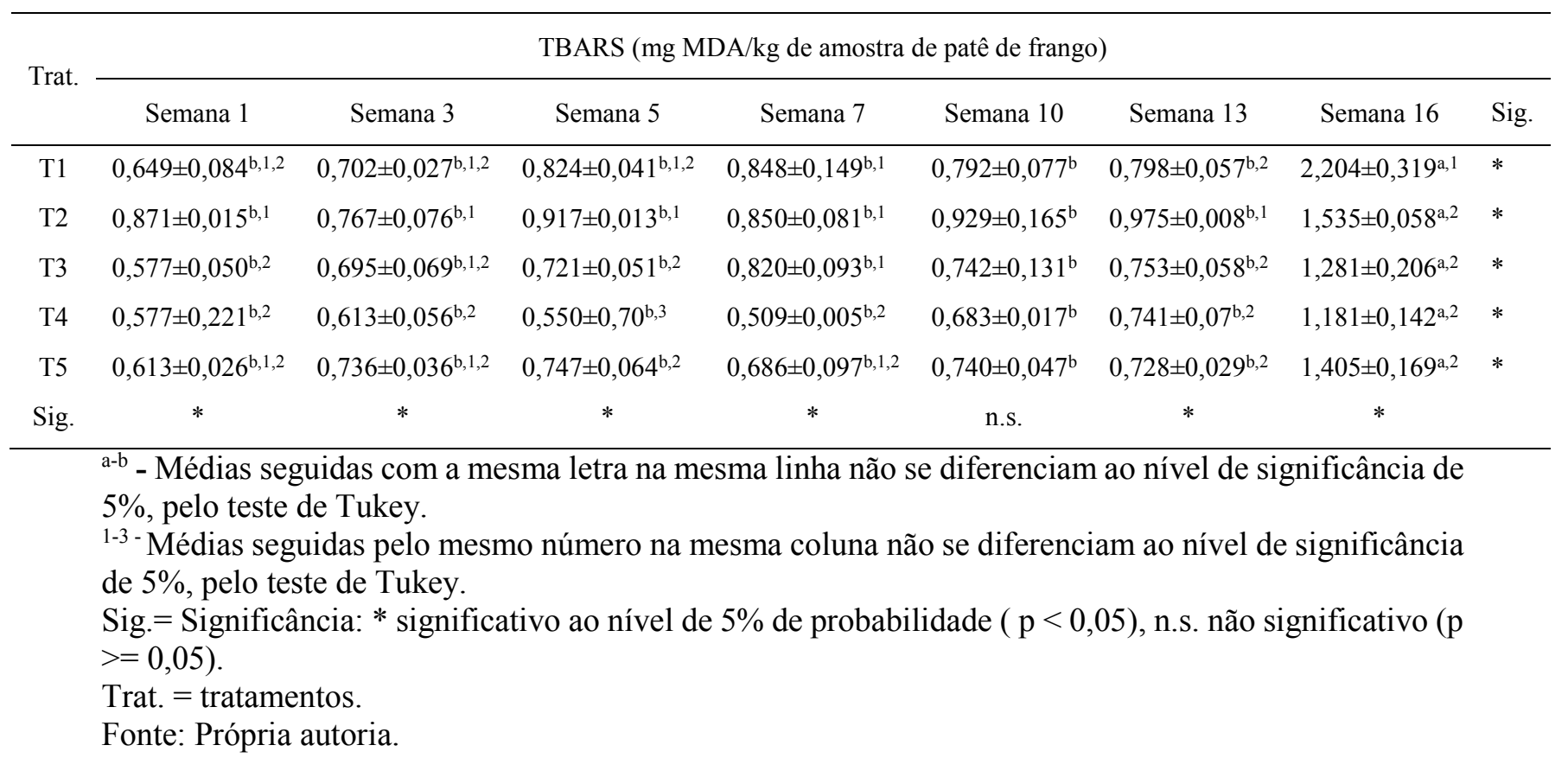

\subsection{Avaliação sensorial do patê de frango}

\subsubsection{Análise microbiológica do patê de frango para realização da análise sensorial}

As análises microbiológicas foram realizadas no patê de frango um dia após o processamento, com a finalidade de avaliar sua qualidade microbiológica e para garantir a segurança do produto que foi submetido à análise sensorial. Para todas as formulações, na análise de contagem micro-organismos de viáveis totais, foi observado $1 \mathrm{UFC} / \mathrm{g}$ de amostra; entretanto, não houve presença de enterobactérias. Os resultados obtidos indicam que o tratamento térmico realizado durante o processamento foi eficiente, e, portanto, o patê de frango empregado na análise sensorial não ofereceu risco microbiológico para a saúde dos provadores. 


\subsubsection{Avaliação do perfil dos provadores}

A caracterização do painel de provadores permitiu traçar um perfil dos 120 membros participantes da análise sensorial, sendo que 68,3\% dos provadores eram mulheres e 31,7\% homens. Em relação à faixa etária, 74,2 \% dos provadores apresentaram idade inferior a 25 anos, $19,2 \%$ entre 25 a 30 anos e $6,6 \%$ entre 36 a 50 anos.

A maioria dos provadores eram alunos de graduação (74,2 \%), mas também fizeram parte da análise sensorial os alunos de pós-graduação $(18,3 \%)$, os funcionários (5\%) e os professores (2,5\%) da Faculdade de Zootecnia e Engenharia de Alimentos (FZEA/USP). As Figuras 33 e 34 ilustram os resultados obtidos em relação ao grau de instrução do chefe da família e a renda familiar dos provadores. A maioria dos chefes das famílias dos provadores $(61,7 \%)$ apresentaram como grau de instrução o superior completo e a renda familiar da maioria dos membros participantes (39,2\%) foi de 3 a 6 salários mínimos ( $\mathrm{R} \$ 2.640,00$ a $\mathrm{R} \$ 5.280,00)$.

Figura 33. Distribuição do grau de instrução do chefe da família dos provadores que participaram da análise sensorial do patê de frango: ( $\square$ ) de analfabeto a fundamental 1 (primário) incompleto; ( $\square$ ) de fundamental 1 (primário) completo a fundamental 2 (ginásio) incompleto; ( $\square$ ) de fundamental 2 (ginásio) completo e médio (colegial) incompleto; ( $\square$ ) de médio (colegial) completo a superior incompleto; ( $\square$ ) superior completo.

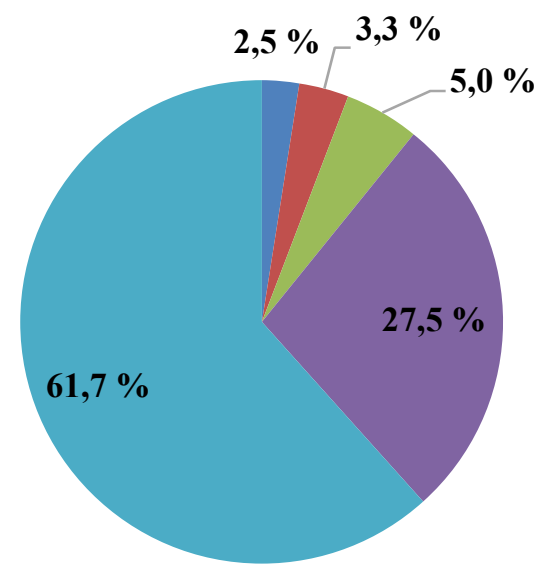

Fonte: Própria autoria. 
Figura 34. Distribuição da renda familiar dos provadores que participaram da análise sensorial do patê de frango: ( $\square$ ) de 1 a 3 salários mínimos ( $\mathrm{R} \$ 880,00$ a $\mathrm{R} \$ 2.640,00)$; ( $\square)$ de 3 a 6 salários mínimos (R\$ 2.640,00 a R \$ 5.280,00); ( $\square$ ) de 6 a 10 salários mínimos ( $\mathrm{R} \$ 5.280,00$ a $\mathrm{R} \$ 8.800,00)$; ( $\square$ ) mais de 10 salários mínimos (acima de $\mathrm{R} \$ 8.800,00$ ).

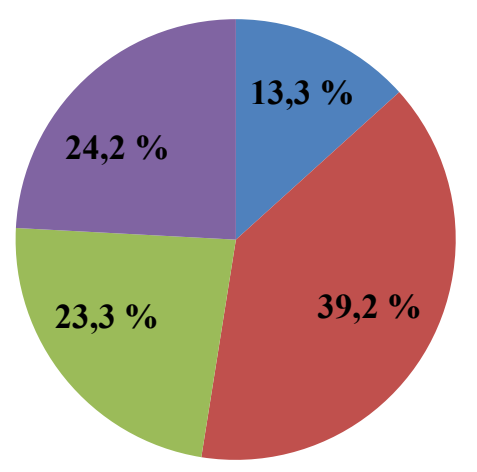

Fonte: Própria autoria.

A frequência de consumo de patê (Figura 35) indicou que $25 \%$ dos provadores consomem patê frequentemente (de 2 a 3 vezes por mês), e em relação ao local de consumo de patê, $51,3 \%$ consomem em casa, 9,9\% em bares e/ou restaurantes e 38,8\% em festas e/ou reuniões familiares. Como o estudo indicou que a maioria das pessoas consomem o produto em casa, elas possuem a capacidade de escolha no ato da compra do alimento e assim, as características sensoriais podem ser decisivas e interferir na escolha do produto cárneo. Portanto, é muito importante avaliar a influência sensorial do OEO nanoemulsionado no patê de frango em estudo. 
Figura 35. Distribuição da frequência de consumo de patê dos provadores que participaram da análise sensorial: ( $\square$ ) sempre (uma vez por semana ou mais); ( $\square$ ) frequentemente (de 2 a 3 vezes por mês); ( $\square$ ) moderadamente (1 vez por mês); ( $\square$ ) algumas vezes (menos que 1 vez por mês); ( $\square$ ) raramente (somente em ocasiões especiais).

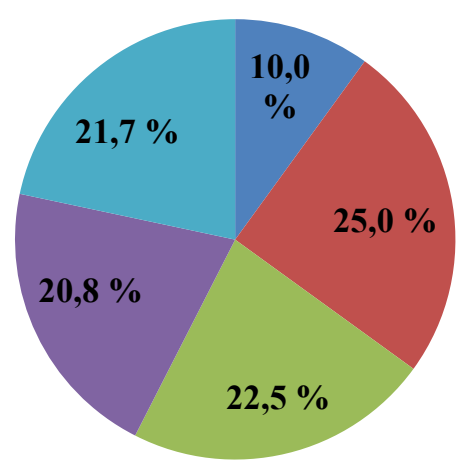

Fonte: Própria autoria.

\subsubsection{Análise sensorial - teste de diferença do controle (análise discriminativa)}

A avaliação de diferença do controle para os atributos cor, odor e sabor foi realizada para avaliar se a adição de OEO não-emulsionado e nanoemulsionado afetaria as características sensoriais do produto cárneo. Como controle, foi utilizado o tratamento com adição de nitrito de sódio e BHT (T5). Em relação a cor, houve uma diferença significativa em relação ao controle para todos os tratamentos e a Figura 36 evidencia essa diferença que está relacionada com a adição do nitrito de sódio, que preserva a coloração rósea do produto, o qual foi adicionada apenas na amostra controle, diferindo portanto, dos demais tratamentos. As análises de odor e sabor (Tabela 11) indicaram que T2, T3 e T4, diferiram significativamente em relação ao controle (T5). Nos T2 e T4 foram adicionados $0,06 \%(\mathrm{~m} / \mathrm{m})$ de OEO livre e nanoemulsionado, respectivamente, e no T3, a adição de OEO nanoemulsionado foi de $0,2 \%$ $(\mathrm{m} / \mathrm{m})$. Portanto, o OEO, mesmo após ser nanoemulsionado, afetou as características sensoriais de odor e sabor do patê de frango nas concentrações utilizadas neste trabalho. Segundo Jongberg et al. (2013), antioxidantes derivados de plantas podem contribuir para uma percepção sensorial alterada quando aplicados em produtos alimentares devido aos compostos voláteis que estão presentes naturalmente no extrato. 
Diversos estudos relataram a influência de OEO nas propriedades sensoriais de carnes. Hulankova, Borilova e Steinhauserova (2013) avaliaram sensorialmente amostras de carne moída cozida após a adição de OEO e em relação ao atributo de odor, as amostras de carne tratadas com mais de $0,2 \%(\mathrm{v} / \mathrm{p})$ de OEO apresentaram odor muito forte e desagradável. Entretanto, Hernández et al. (2017) que avaliaram as características sensoriais de carne seca após a adição de OEO em concentrações mais baixa, observou que após a adição de 0,014 \% (v/v) de OEO, o odor foi significativamente mais intenso em relação a amostra controle (sem adição de OEO) e nesta concentração, o OEO proporcionou um odor agradável para a carne.

Figura 36. Porcentagens de provadores correspondente aos atributos de cor utilizando a escala de diferença do controle: $0=$ nenhuma diferença do controle, $1=$ ligeiramente diferente do controle, $2=$ pouco diferente do controle, $3=$ muito diferente do controle, $4=$ muitíssimo diferente do controle, $5=$ extremamente diferente do controle. (घ) T1: sem antioxidantes e conservantes, (घ) T2: adição de 0,06 $\%(\mathrm{~m} / \mathrm{m})$ de óleo essencial de orégano não-emulsionado, ( $($ ) T3: adição de $6 \%(\mathrm{~m} / \mathrm{m})$ das nanoemulsões NA-3,25 e (घ) T4: adição de 1,2\% (m/m) das nanoemulsões NA-5.

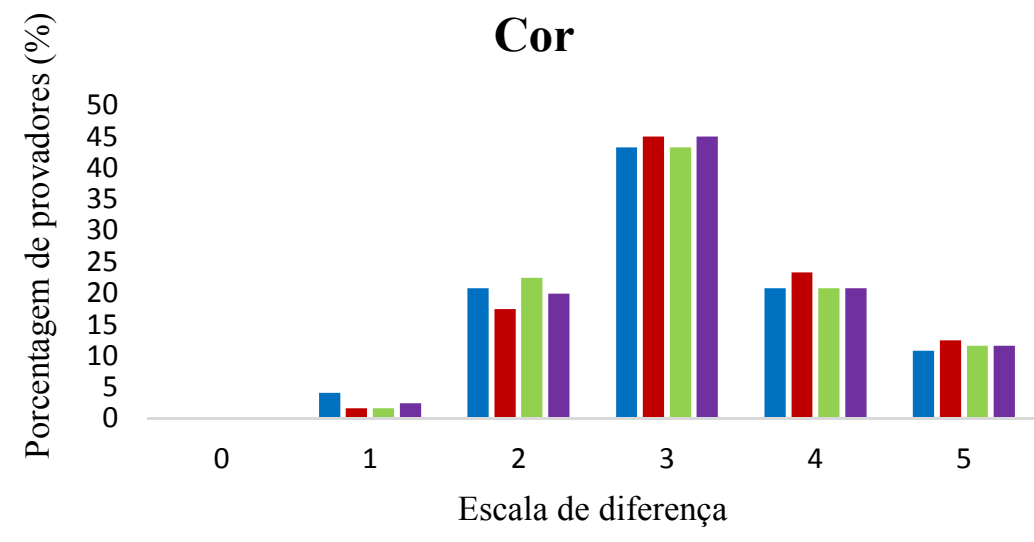

Fonte: Própria autoria.

A Tabela 11 mostra que para os atributos de sabor e odor, T3 (adição de NA-3,25) apresentou maior valor em relação ao tratamento controle (T5), entretanto, este valor não apresentou diferença significativa para os tratamentos T2 e T4, com adição de OEO livre e das nanoemulsões NA-5, respectivamente. 
Tabela 11. Valores médios das notas atribuídas para os atributos de sabor e odor utilizando a escala de diferença do controle: $0=$ nenhuma diferença do controle, $1=$ ligeiramente diferente do controle, $2=$ pouco diferente do controle, $3=$ muito diferente do controle, $4=$ muitíssimo diferente do controle, $5=$ extremamente diferente do controle. Tratamentos: T2: adição de $0,06 \%(\mathrm{~m} / \mathrm{m})$ de óleo essencial de orégano não-emulsionado, T3: adição de $6 \%(\mathrm{~m} / \mathrm{m})$ das nanoemulsões NA-3,25, T4: adição de 1,2 \% $(\mathrm{m} / \mathrm{m})$ das nanoemulsões NA-5 e T5: adição de BHT e nitrito de sódio.

\begin{tabular}{cccccc}
\hline \multirow{2}{*}{ Atributos } & \multicolumn{5}{c}{ Tratamentos } \\
\cline { 2 - 6 } & $\mathrm{T} 2$ & $\mathrm{~T} 3$ & $\mathrm{~T} 4$ & $\mathrm{~T} 5$ & Sig. \\
\hline Sabor & $2,3 \pm 0,98^{\mathrm{b}}$ & $3,4 \pm 1,05^{\mathrm{b}}$ & $2,4 \pm 1,0^{\mathrm{b}}$ & $1,6 \pm 0,89^{\mathrm{a}}$ & $*$ \\
Odor & $2,7 \pm 1,04^{\mathrm{b}}$ & $3,8 \pm 1,05^{\mathrm{b}}$ & $2,9 \pm 0,98^{\mathrm{b}}$ & $2,1 \pm 0,85^{\mathrm{a}}$ & $*$ \\
\hline
\end{tabular}

a-b - Médias seguidas com a mesma letra na mesma linha não se diferenciam ao nível de significância de $5 \%$, pelo teste de Dunnett.

Sig.= Significância: * significativo ao nível de $5 \%$ de probabilidade $(\mathrm{p}<0,05)$.

Fonte: Própria autoria.

\subsubsection{Análise sensorial - teste de aceitação (análise afetiva)}

A análise de aceitação para os atributos de odor e cor, assim como a qualidade global do patê de frango, submetido aos 5 tratamentos, foi realizada para verificar se as alterações sensoriais, relacionadas com o produto cárneo durante a estocagem, afetariam a aceitação do produto cárneo pelos consumidores. Segundo Estévez, Ventanas e Cava (2005) e Pateiro et al. (2014) a oxidação dos lipídios pode gerar compostos residuais como aldeídos e cetonas, os quais acarretam na deterioração nutricional e sensorial dos produtos, afetando o odor, a cor e a textura de produtos cárneos.

As Tabelas 12, 13 e 14 mostram os resultados das análises de aceitação realizadas durante o armazenamento. Para os atributos de odor e cor e a qualidade global do produto cárneo, não houve diferença significativa $(\mathrm{p}<0,05)$ entre os dias 1 e 90 para todos os tratamentos. Com isso, as alterações sensoriais de cor e odor que podem ocorrem devido a oxidação do produto cárneo durante o armazenamento, não afetaram a aceitação dos consumidores em todos os tratamentos. Na Figura 37 é possível visualizar a coloração das amostras de patê de frango, submetidas aos 5 tratamentos, durante a estocagem.Para todos os tratamentos, o patê de frango foi considerado com boa aceitação em relação a cor, odor e qualidade global após 90 dias de armazenamento pois segundo Labuza e Shmidl (1988) o fim 
da vida de prateleira de um produto é considerado quando há uma diminuição de 1,5 pontos na escala hedônica, o que não foi observado nesse estudo.

Tabela 12. Valores médios das notas atribuídas para odor na análise sensorial, utilizando a escala hedônica estruturada de 9 pontos, durante o período de armazenagem de 90 dias. Tratamentos: T1: sem antioxidantes e conservantes, T2: adição de $0,06 \%(\mathrm{~m} / \mathrm{m})$ de óleo essencial de orégano nãoemulsionado, T3: adição de $6 \%(\mathrm{~m} / \mathrm{m})$ das nanoemulsões NA-3,25, T4: adição de $1,2 \%(\mathrm{~m} / \mathrm{m})$ das nanoemulsões NA-5 e T5: adição de BHT e nitrito de sódio.

\begin{tabular}{cccccc}
\hline \multirow{2}{*}{ Tratamento } & \multicolumn{5}{c}{ Odor } \\
\cline { 2 - 6 } & Dia 1 & Dia 30 & Dia 60 & Dia 90 & Sig. \\
\hline T1 & $5,24 \pm 1,85$ & $5,45 \pm 1,95$ & $5,33 \pm 2,07$ & $5,25 \pm 2,04$ & n.s. \\
T2 & $6,97 \pm 1,65$ & $6,56 \pm 1,75$ & $6,65 \pm 2,13$ & $6,86 \pm 1,66$ & n.s. \\
T3 & $6,53 \pm 1,88$ & $6,13 \pm 1,99$ & $6,48 \pm 1,81$ & $6,39 \pm 1,84$ & n.s. \\
T4 & $6,44 \pm 1,77^{\mathrm{a}}$ & $6,02 \pm 1,77^{\mathrm{ab}}$ & $5,77 \pm 1,92^{\mathrm{b}}$ & $5,85 \pm 1,84^{\mathrm{ab}}$ & $*$ \\
T5 & $4,63 \pm 1,92$ & $4,61 \pm 2,01$ & $4,84 \pm 1,99$ & $5,25 \pm 1,89$ & n.s. \\
\hline
\end{tabular}

$\overline{a-b}$ - Médias seguidas com a mesma letra na mesma linha não se diferenciam ao nível de significância de $5 \%$, pelo teste de Tukey. Sig.= Significância: * significativo ao nível de $5 \%$ de probabilidade $(\mathrm{p}<0,05)$, n.s. não significativo $(\mathrm{p}>=0,05)$.

Fonte: Própria autoria.

Tabela 13. Valores médios das notas atribuídas para cor na análise sensorial, utilizando a escala hedônica estruturada de 9 pontos, durante o período de armazenagem de 90 dias. Tratamentos: T1: sem antioxidantes e conservantes, T2: adição de $0,06 \%(\mathrm{~m} / \mathrm{m})$ de óleo essencial de orégano nãoemulsionado, T3: adição de $6 \%(\mathrm{~m} / \mathrm{m})$ das nanoemulsões NA-3,25, T4: adição de $1,2 \%(\mathrm{~m} / \mathrm{m})$ das nanoemulsões NA-5 e T5: adição de BHT e nitrito de sódio.

\begin{tabular}{cccccl}
\hline \multirow{2}{*}{ Tratamento } & \multicolumn{5}{c}{ Cor } \\
\cline { 2 - 6 } & Dia 1 & Dia 30 & Dia 60 & Dia 90 & Sig. \\
\hline T1 & $5,26 \pm 1,73$ & $5,30 \pm 1,75$ & $5,34 \pm 1,73$ & $5,02 \pm 1,78$ & n.s. \\
T2 & $5,60 \pm 1,71$ & $5,69 \pm 1,69$ & $5,88 \pm 1,85$ & $5,59 \pm 1,72$ & n.s. \\
T3 & $5,59 \pm 1,61$ & $5,77 \pm 1,69$ & $6,04 \pm 1,64$ & $5,60 \pm 1,61$ & n.s. \\
T4 & $5,67 \pm 1,75$ & $5,46 \pm 1,74$ & $5,79 \pm 1,72$ & $5,39 \pm 1,61$ & n.s. \\
T5 & $5,75 \pm 2,09$ & $5,59 \pm 2,10$ & $6,05 \pm 2,07$ & $6,03 \pm 1,95$ & n.s. \\
\hline
\end{tabular}

Sig.= Significância: $n$. $s$. não significativo $(\mathrm{p}>=0,05)$.

Fonte: Própria autoria. 
Tabela 14. Valores médios das notas atribuídas para qualidade global na análise sensorial, utilizando a escala hedônica estruturada de 9 pontos, durante o período de armazenagem de 90 dias. Tratamentos: T1: sem antioxidantes e conservantes, T2: adição de $0,06 \%(\mathrm{~m} / \mathrm{m})$ de óleo essencial de orégano nãoemulsionado, T3: adição de $6 \%(\mathrm{~m} / \mathrm{m})$ das nanoemulsões NA-3,25, T4: adição de 1,2 \% (m/m) das nanoemulsões NA-5 e T5: adição de BHT e nitrito de sódio.

\begin{tabular}{cccccc}
\hline \multirow{2}{*}{ Tratamento } & \multicolumn{5}{c}{ Qualidade global } \\
\cline { 2 - 6 } & Dia 1 & Dia 30 & Dia 60 & Dia 90 & Sig. \\
\hline T1 & $5,28 \pm 1,65$ & $5,53 \pm 1,645$ & $5,36 \pm 1,61$ & $5,21 \pm 1,69$ & n.s. \\
T2 & $6,42 \pm 1,44$ & $6,36 \pm 1,53$ & $6,38 \pm 1,66$ & $6,22 \pm 1,61$ & n.s. \\
T3 & $6,12 \pm 1,55$ & $6,13 \pm 1,65$ & $6,21 \pm 1,44$ & $6,07 \pm 1,44$ & n.s. \\
T4 & $6,07 \pm 1,57$ & $5,85 \pm 1,55$ & $5,76 \pm 1,65$ & $5,65 \pm 1,59$ & n.s. \\
T5 & $5,18 \pm 1,87^{\text {ab }}$ & $5,05 \pm 1,87^{\mathrm{b}}$ & $5,48 \pm 1,74^{\mathrm{ab}}$ & $5,74 \pm 1,73^{\mathrm{a}}$ & $*$ \\
\hline
\end{tabular}

a-b - Médias seguidas com a mesma letra na mesma linha não se diferenciam ao nível de significância de $5 \%$, pelo teste de Tukey.

Sig. = Significância: * significativo ao nível de $5 \%$ de probabilidade $(\mathrm{p}<0,05)$, n.s. não significativo (p $>=0,05)$.

Fonte: Própria autoria. 
Figura 37. Aspecto visual dos patês de frango nos dias 1 e 90 de armazenamento. Da esquerda para direita: T 1: sem antioxidantes e conservantes, T 2: adição de $0,06 \%(\mathrm{~m} / \mathrm{m})$ de óleo essencial de orégano não-emulsionado, T3: adição de $6 \%(\mathrm{~m} / \mathrm{m})$ das nanoemulsões NA-3,25, T4: adição de $1,2 \%(\mathrm{~m} / \mathrm{m})$ das nanoemulsões NA-5 e T5: adição de BHT e nitrito de sódio.

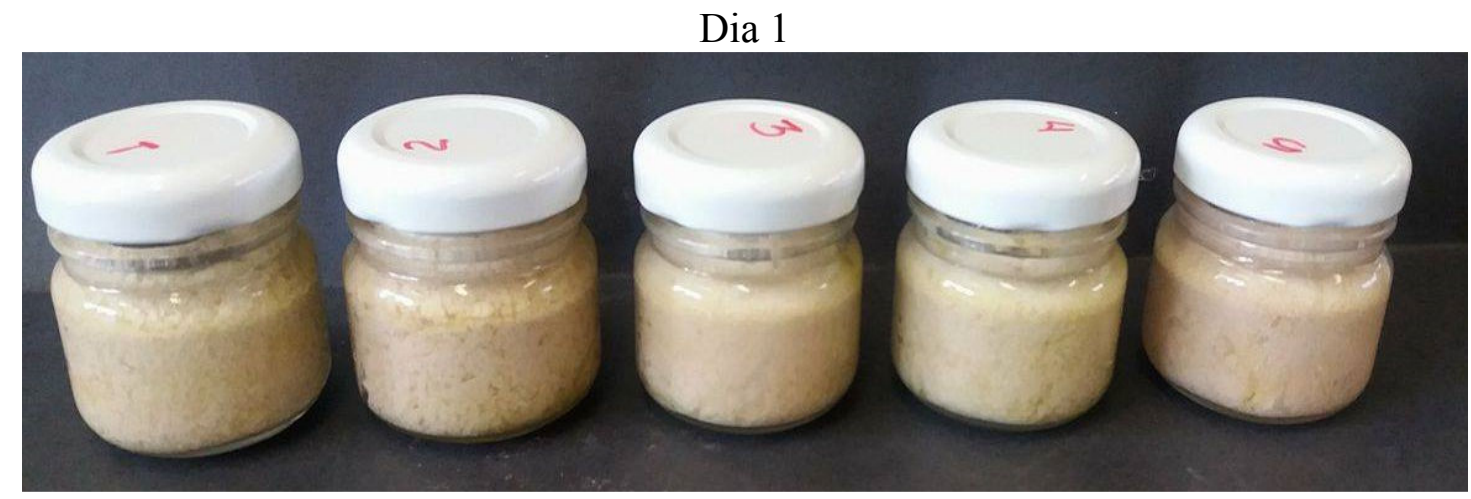

Dia 90

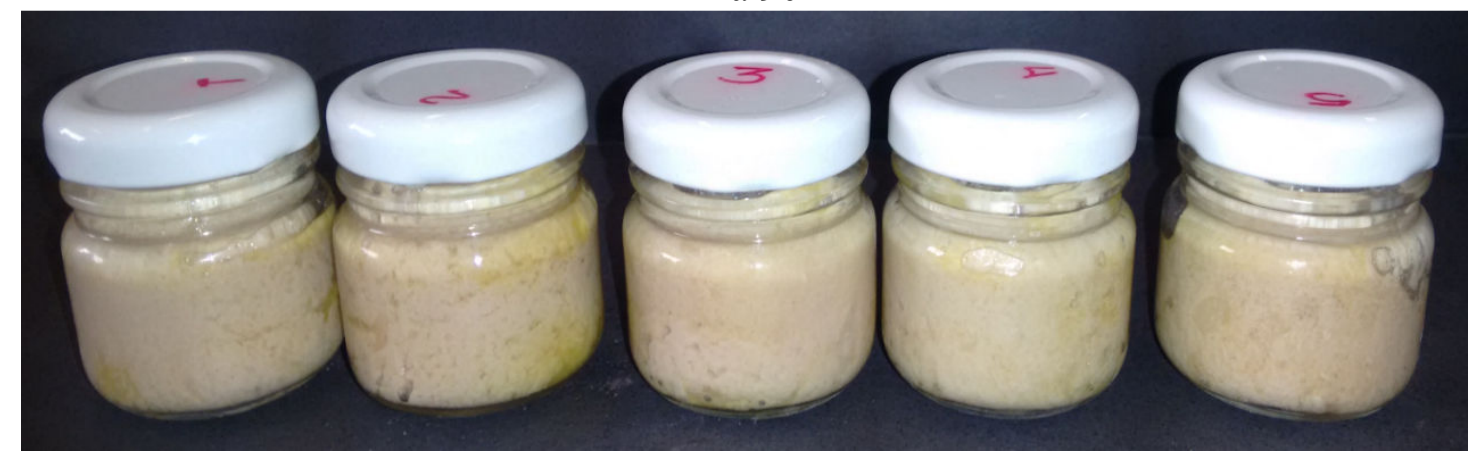

Fonte: Própria autoria.

\subsubsection{Análise sensorial - teste de aceitação (análise afetiva) e intenção de compra}

Os resultados obtidos pelo teste de diferença do controle (item 5.11.3) indicaram que a adição de OEO não-emulsionado e nanoemulsionado afetaram as propriedades sensoriais de odor, cor e sabor em relação a amostra controle (sem adição do óleo), entretanto, para avaliar se essas alterações afetariam a aceitação do produto cárneo em relação ao odor, cor e sabor, foi realizado um teste de aceitação para cada atributo.

Para o atributo de odor, T3 (adição das nanoemulsões NA-3,25) obteve o menor valor médio, o qual foi significativamente menor em relação aos outros tratamentos (análise de média na Tabela 15). Em relação ao atributo de sabor, T3 obteve a menor nota em comparação com os demais tratamentos, a qual foi de 3,83 na escala hedônica de 9 pontos. Segundo Quiroga, Grosso e Nepote (2013), uma amostra de alimento pode ser considerada inaceitável para o consumidor quando a aceitação do atributo tiver um valor inferior a 5 numa escala hedônica de 
9 pontos, e portanto, pode-se considerar que de todos os 5 tratamentos de patê de frango analisados, apenas T3 foi considerado inaceitável pelos provadores.

A baixa aceitação do patê de frango do tratamento 3 está associada com um sabor amago identificado pelos provadores durante a análise sensorial. Este sabor de amargo está relacionado com uma maior concentração de OEO no T3, que foi de $0,2 \%(\mathrm{~m} / \mathrm{m})$, sendo que nos tratamentos 2 e 4, nos quais a concentração do óleo foi menor, $0,06 \%(\mathrm{~m} / \mathrm{m})$, este sabor amargo não foi relatado pelos provadores. O mesmo comportamento, em relação ao sabor, foi observado em um estudo realizado por Hernández et al. (2017), os quais relataram que em maiores concentrações de OEO as amostras de carne foram julgadas como amargas, adstringentes e pungentes.

Na avaliação da cor, Tabela 15, o T5 apresentou valor médio significativamente maior do que os demais tratamentos, indicando uma maior preferência dos consumidores pela coloração rósea do patê de frango, o qual é atribuída pela adição de nitrito de sódio no T5. Segundo Viuda-Martos et al. (2009) o nitrito é amplamente utilizado como agente de cura na indústria de carne e embora nos últimos anos tenha sido proposta a sua omissão no processamento de carne, devido aos efeitos citotóxicos de nitrosaminas, o uso de nitrito no processamento de carne tem efeitos importantes em relação ao desenvolvimento de cor, oxidação de gordura, sabor e segurança microbiológica. No entanto, a razão mais importante para a adição de nitrito em produtos cárneos curados é a formação da cor típica vermelha ou rósea, e embora algumas alternativas ao uso de nitrito no processamento de carne tenham sido propostas, eles são difíceis de substituir devido a esta característica (VIUDA-MARTOS et al., 2009).

Portanto, uma alternativa para viabilizar a utilização de OEO nanoemulsionado como agente antibacteriano e antioxidante, sem afetar as propriedades sensoriais de cor do patê de frango, seria uma redução parcial do nitrito e/ou a utilização de corantes naturais para conferir coloração rósea ao produto. Zarringhalami, Sahari e Hamidi-Esfehani (2009) utilizaram pó de urucum como substituintes do nitrito em salsichas, para isso, estudaram substituição de $20 \%$, $40 \%, 60 \%, 80 \%$ e $100 \%$ de nitrito e os resultados mostraram que a amostra contendo $60 \%$ de urucum não mostrou diferenças significativas em relação ao controle (sem substituição de nitrito) para o atributo de cor.

Os valores para os atributos de odor, cor e sabor para T2 e T4, com adição de $0,06 \%$ $(\mathrm{m} / \mathrm{m})$ de OEO não-emulsionado e nanoemulsionado, respectivamente, não apresentaram 
diferença significativa entre si, indicando que a nanoencapsulação do OEO não amenizou os efeitos deste óleo sobre as propriedades sensoriais deste produto cárneo. Um estudo realizado por Lane et al. (2013) avaliou as características sensoriais de iogurte de morango após a adição de óleo de algas, não-emulsionado e nanoemulsionado, e observou que as nanoemulsões também influenciaram significativamente o aroma, o sabor, a textura e aceitabilidade do iogurte de morango. Segundo Walker, Decker e McClements (2015), poucos trabalhos têm pesquisado o efeito de nanoemulsões sobre as propriedades sensoriais dos alimentos e sugerem que mais pesquisas devem ser conduzidas para avaliar os aspectos sensoriais de alimentos com nanoemulsões para entender melhor seu efeito sobre a aceitação do consumidor.

Tabela 15. Valores médios dos atributos de odor, cor e sabor obtidos pelo teste de aceitação, utilizando a escala hedônica estruturada de 9 pontos ( $1=$ desgostei muitíssimo, $2=$ desgostei muito, $3=$ desgostei regularmente, $4=$ desgostei ligeiramente, $5=$ indiferente, $6=$ gostei ligeiramente, $7=$ gostei regularmente, 8= gostei muito e 9=gostei muitíssimo). Tratamentos: T1: sem antioxidantes e conservantes, T2: adição de $0,06 \%(\mathrm{~m} / \mathrm{m})$ de óleo essencial de orégano não-emulsionado, T3: adição de $6 \%(\mathrm{~m} / \mathrm{m})$ das nanoemulsões NA-3,25, T4: adição de $1,2 \%(\mathrm{~m} / \mathrm{m})$ das nanoemulsões NA-5 e T5: adição de BHT e nitrito de sódio.

\begin{tabular}{cccc}
\hline Tratamento & Odor & Cor & Sabor \\
\hline T1 & $6,33 \pm 1,53^{\mathrm{a}}$ & $5,73 \pm 1,65^{\mathrm{b}}$ & $6,34 \pm 1,65^{\mathrm{a}}$ \\
T2 & $6,40 \pm 1,58^{\mathrm{a}}$ & $5,72 \pm 1,65^{\mathrm{b}}$ & $6,18 \pm 1,82^{\mathrm{ab}}$ \\
T3 & $5,56 \pm 2,26^{\mathrm{b}}$ & $5,63 \pm 1,70^{\mathrm{b}}$ & $3,83 \pm 2,24^{\mathrm{c}}$ \\
T4 & $6,40 \pm 1,76^{\mathrm{a}}$ & $5,81 \pm 1,68^{\mathrm{b}}$ & $5,65 \pm 2,04^{\mathrm{b}}$ \\
T5 & $6,26 \pm 1,75^{\mathrm{a}}$ & $6,58 \pm 1,69^{\mathrm{a}}$ & $6,61 \pm 1,68^{\mathrm{a}}$ \\
Sig. & $*$ & $*$ & $*$ \\
\hline
\end{tabular}

$\overline{\mathrm{a}-\mathrm{b}}$ - Médias seguidas com a mesma letra na mesma coluna não se diferenciam ao nível de significância de $5 \%$, pelo teste de Tukey.

Sig.= Significância: * significativo ao nível de $5 \%$ de probabilidade $(\mathrm{p}<0,05)$.

Fonte: Própria autoria.

A intenção de compra do produto realizada mostra que para T1, T2, T3, T4 e T5, a porcentagem de provadores que certamente compraria o produto foi de $11,7,17,5,4,2,15 \mathrm{e}$ $27,5 \%$, respectivamente, conforme a Figura 38. Estes resultados mostraram que as amostras do T5 (com adição de nitrito de sódio) obtiveram maior intenção de compra pelos consumidores, e portanto, apresentaram maior aceitação em relação aos demais tratamentos. O 
T3 foi o que apresentou menor intenção de compras, e este resultado está relacionado com os baixos valores médios dos atributos de odor, cor e sabor que foram obtidos no teste de aceitação (conforme mostra a Tabela 15). 
Figura 38. Distribuição da intenção de compra dos provadores em relação as amostras de patê de frango: ( $\square$ ) certamente não compraria o produto; ( $\square$ ) possivelmente não compraria o produto; ( $\square$ ) talvez compraria / talvez não compraria; ( $\square$ ) possivelmente compraria o produto; ( $\square$ ) certamente compraria o produto. Tratamentos: T1: sem antioxidantes e conservantes, T2: adição de $0,06 \%(\mathrm{~m} / \mathrm{m})$ de óleo essencial de orégano não-emulsionado, T3: adição de $6 \%(\mathrm{~m} / \mathrm{m})$ das nanoemulsões NA-3,25, T4: adição de $1,2 \%(\mathrm{~m} / \mathrm{m})$ das nanoemulsões NA-5 e T5: adição de BHT e nitrito de sódio.

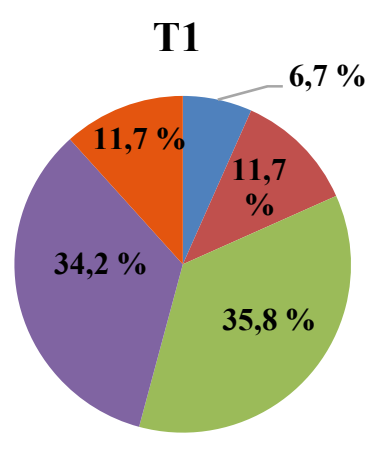

\section{T2}

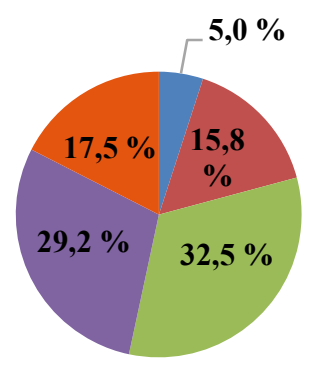

T3

T4
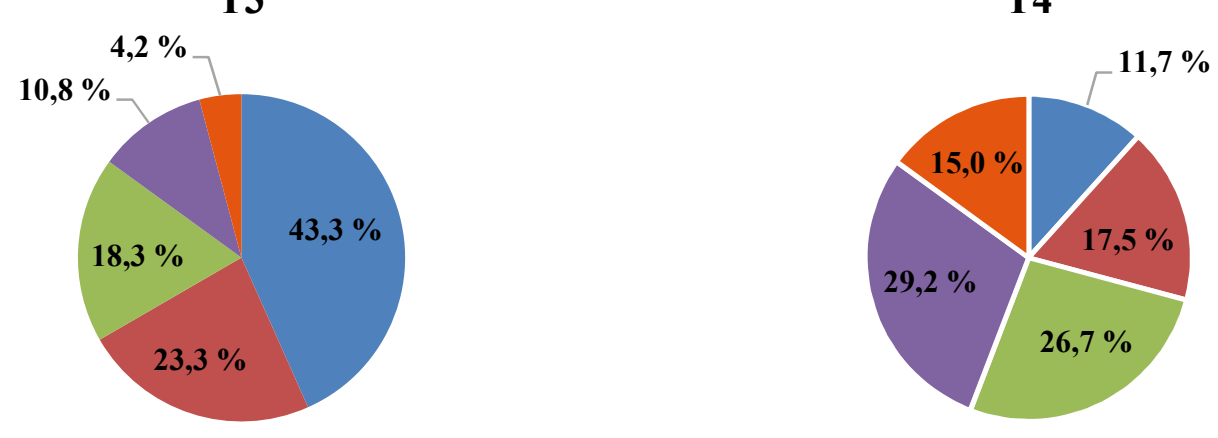

T5

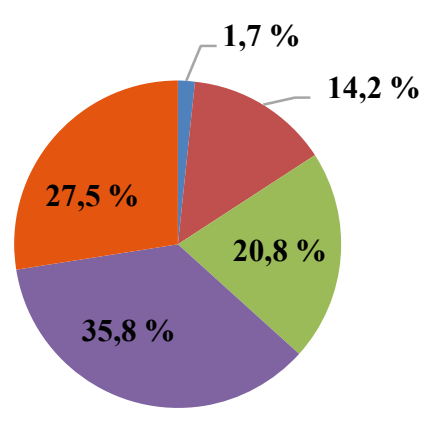

Fonte: Própria autoria. 


\section{CONCLUSÕES}

Os dados obtidos nesta Tese permitiram concluir que as temperaturas de inversão de fases ( $\left.\mathrm{T}_{\mathrm{PIT}}\right)$, determinadas durante a produção das nanoemulsões, variaram com a quantidade de $\mathrm{OE}$ e o tipo de tensoativos empregados nas formulações. As nanoemulsões encapsulando OEO apresentaram reduzidos tamanhos de gota $(25,5 \pm 0,21$ e $42,4 \pm 1,7 \mathrm{~nm})$, os quais foram influenciados pelo tipo de tensoativos empregados nas formulações. As nanoemulsões permaneceram estáveis durante 90 dias, pois os valores do tamanho de diâmetro médio das gotas e os índices de polidispersidade não apresentaram diferença significativa durante este período.

Os baixos valores de CIM e CBM de ambas as nanoemulsões indicaram elevado potencial antibacteriano in vitro para $S$. aureus e E. coli, sendo que, a perda dos compostos voláteis pelas nanoemulsões não afetaram a atividade antibacteriana durante 90 dias de armazenamento.

O OEO não-emulsionado, assim como as nanoemulsões encapsulando OEO, apresentaram elevado potencial antioxidante e, portanto, pode ser considerado promissor o estudo deste óleo como agente antioxidante dos alimentos. Os resultados indicaram que a estrutura das nanoemulsões apresentaram significativa importância para a proteção da atividade antioxidante deste OE durante o armazenamento.

Em relação à atividade antibacteriana no patê de frango, ambas as nanoemulsões foram eficientes em reduzir a multiplicação de $S$. aureus e E.coli após 8 dias de contaminação, sendo que o OEO nanoemulsionado apresentou maior potencial antibacteriano no patê de frango do que o OEO não-emulsionado, devido à proteção do OEO, pelo sistema nanoemulsionado, contra as interações com os constituintes dos alimentos, como as proteínas e os lipídios.

A análise dos parâmetros de cor durante o armazenamento do patê de frango indicou uma descoloração do pigmento para todos os tratamentos do patê de frango, a qual foi relacionada com a oxidação proteica e com mudanças químicas ou na composição do patê. Além disso, o OEO não-emulsionado, assim como o OEO nanoemulsionado e o antioxidante sintético BHT não foram eficientes em inibir a oxidação proteíca deste produto cárneo.

Entretanto, em relação às análises de oxidação lipídica, foi possível concluir que o OEO nanoemulsionado apresentou maior potencial antioxidante que o OEO não-emulsionado e o antioxidante sintético BHT, evidenciando assim, o potencial de aplicação destas nanoemulsões em sistemas alimentares. 
Contrariando a hipótese inicial de que as nanoemulsões seriam capazes de minimizar as alterações nas propriedades sensoriais do alimento pelo OEO, a análise sensorial do patê de frango mostrou que tanto o OEO não-emulsionado quanto emulsionado influenciaram nas propriedades sensoriais do patê de frango, nas concentrações empregadas neste estudo. Além disso, a aceitação do patê de frango foi relacionada com as concentrações de OEO, sendo que em maiores concentrações, o patê de frango apresentou menor aceitação para os atributos de cor, odor e sabor e menor intenção de compra pelos provadores. Sendo assim, as nanoemulsões NA-5 seriam mais indicadas para serem aplicadas em produtos cárneos, uma vez que apresentou maior aceitação sensorial em relação ao tratamento de patê de frango contendo as nanoemulsões NA-3,25.

Por fim, o desenvolvimento deste trabalho mostrou que é possível encapsular OE em sistemas nanoemulsionados estáveis e com reduzido tamanho de gotas. Além disso, as nanoemulsões foram eficientes em preservar a atividade antimicrobiana e antioxidante do OEO in vitro e no patê de frango durante o armazenamento, indicando que as nanoemulsões encapsulando OEO, em concentrações adequadas, podem ser promissoras na substituição total ou parcial de conservantes e antioxidantes sintéticos empregados na indústria de produtos cárneos. 


\section{SUGESTÕES PARA ESTUDOS FUTUROS}

A partir dos resultados obtidos neste Tese, os seguintes estudos são sugeridos para futuros trabalhos:

- Produção de nanoemulsões encapsulando outros tipos de OE pelo método de temperatura de inversão de fases;

- Avaliação da atividade antioxidante e antibacteriana de uma mistura dos compostos carvacrol, timol e $\gamma$-terpineno encapsulada em nanoemulsões.

- Aplicação das nanoemulsões encapsulando OEO em matriz alimentícia aquosa (por exemplo sucos ou molhos), com a finalidade de avaliar a atividade antimicrobiana;

- Avaliação da atividade antibacteriana das nanoemulsões de OEO para outros tipos de bactérias de importância em episódios de contaminação microbiana em alimentos;

- Determinação da concentração necessária de OEO nanoemulsionado que não afete as propriedades de cor, sabor e odor do patê de frango, para posteriormente trabalhar com o OEO nanoemulsionado associado com outros agentes antimicrobiano e antioxidante naturais para atingir ação antimicrobiana e antioxidante no produto cárneo. 


\section{REFERÊNCIAS BIBLIOGRÁFICAS}

AKARPAT, A.; TURHAN, S.; USTUN, N. S. (2008). Effects of hot-water extracts from myrtle, rosemary, nettle and lemon balm leaves on lipid oxidation and color of beef patties during frozen storage. Journal of Food Processing and Preservation, Westport, v. 32, n. 1, p. 117-132, 2008.

AL-HIJAZEEN, M. et al. Effect of oregano essential oil (Origanum vulgare subsp. hirtum) on the storage stability and quality parameters of ground chicken breast meat. Antioxidants, Basel, v. 5, n. 2, p. 18, 2016.

ALLOUCHE, J. et al. Simultaneous conductivity and viscosity measurements as a technique to track emulsion inversion by the phase-inversion-temperature method. Langmuir, Washington, v. 20, n. 6, p. 2134-2140, 2004.

ANTON, N. et al. Nano-emulsions and nanocapsules by the PIT method: an investigation on the role of the temperature cycling on the emulsion phase inversion. International Journal of Pharmaceutics, Amsterdam, v. 344, n. 1, p. 44-52, 2007.

ANTON, N.; BENOIT, J. P.; SAULNIER, P. Particular conductive behaviors of emulsion phase inverting. Journal of Drug Delivery Science and Technology, Paris, v. 18, n. 2, p. 95 99, 2008b.

ANTON, N.; BENOIT, J.P.; SAULNIER, P. Design and production of nanoparticles formulated from nano-emulsion templates-A review. Journal of Controlled Release, Amsterdam, v. 128, n. 3, p. 185-199, 2008a.

ANTON, N.; VANDAMME, T. F. The universality of low-energy nano-emulsification. International Journal of Pharmaceutics, Amsterdam, v. 377, n. 1, p. 142-147, 2009.

ANWER, M. K. et al. Enhanced antibacterial effects of clove essential oil by nanoemulsion. Journal of Oleo Science, Tokyo, v. 63, n. 4, p. 347-354, 2014.

AOAC. Ashes content. 920.153. AOAC (2000). In Official methods of analysis. 17 th ed. Gaithersburgh: Maryland, 2000c. 
AOAC. Moisture content. 950.46. AOAC (2000). In: Official methods of analysis. 17 th ed. Gaithersburgh: Maryland, 200a.

AOAC. Official Method 2003.07: Enumeration of Staphylococcus aureus in Selected Types of Processed and Prepared Foods. 3MTM PetrifilmTM Staph Express Plate Method. AOAC (2006). In Official methods of analysis. 18 th ed. Gaithersburgh:Maryland, 2006.

AOAC. Protein content in meat. 928.08. AOAC (2000). In Official methods of analysis. 17 th ed. Gaithersburgh:Maryland, 2000b.

AQUERRETA, Y. et al. Composition of pâtés elaborated with mackerel flesh (Scomber scombrus) and tuna liver (Thunnus thynnus): comparison with commercial fish pâtés. Food Chemistry, Amsterdam, v. 77, n. 2, p. 147-153, 2002.

ARABSHAHI-D, S.; DEVI, D. V.; UROOJ, A. Evaluation of antioxidant activity of some plant extracts and their heat, $\mathrm{pH}$ and storage stability. Food Chemistry, Amsterdam, v. 100, n. 3, p. 1100-1105, 2007.

ARMENTA, S.; GARRIGUES, S.; DE LA GUARDIA, M. Determination of edible oil parameters by near infrared spectrometry. Analytica Chimica Acta, Amsterdam, v. 596, n. 2, p. 330-337, 2007.

ARTIGA-ARTIGAS, M.; ACEVEDO-FANI, A.; MARTÍN-BELLOSO, O. Improving the shelf life of low-fat cut cheese using nanoemulsion-based edible coatings containing oregano essential oil and mandarin fiber. Food Control, Vurrey, v. 76, p. 1-12, 2017.

BABILI, F. E. et al. Oregano: chemical analysis and evaluation of its antimalarial, antioxidant, and cytotoxic activities. Journal of Food Science, Hoboken, v. 76, n. 3, p. C512-C518, 2011.

BAHRAMI, B. et al. The antimicrobial and antioxidant potencies of Satureja khuzistanica essential oil for preserving of vegetable oils. Journal of Microbiology, Biotechnology and Food Sciences, Nitra, v. 6, n. 3, p. 979-982, 2016.

BAKKALI, F. et al. Biological effects of essential oils-a review. Food and Chemical Toxicology, Oxford, v. 46, n.2, p. 446-475, 2008. 
BANDONIEN, D.; MURKOVIC, M. The detection of radical scavenging compounds in crude extract of borage (Borago officinalis L.) by using an on-line HPLC-DPPH method. Journal of Biochemical and Biophysical Methods, Amsterdam v. 53, n. 1, p. 45-49, 2002.

BHARGAVA, K. et al. Application of an oregano oil nanoemulsion to the control of foodborne bacteria on fresh lettuce. Food Microbiology, London, v. 47, p. 69-73, 2015.

BLIGH, E.; DYER, W. J. A rapid method of total lipid extraction and purification. Canadian Journal of Biochemistry and Physiology, Ottawa, v. 37, n. 8, p. 911-917, 1959.

BOROSKI, M. et al. Use of oregano extract and oregano essential oil as antioxidants in functional dairy beverage formulations. LWT-Food Science and Technology, London, v. 47, n. 1, p. 167-174, 2012.

BOSELLI, E. et al. Photoxidation of cholesterol and lipids of turkey meat during storage under commercial retail conditions. Food Chemistry, Amsterdam, v. 91, n. 4, p. 705-713, 2005.

BRAND-WILLIAMS, W.; CUVELIER, M. E.; BERSET, C. L. W. T. Use of a free radical method to evaluate antioxidant activity. LWT-Food Science and Technology, London, v. 28, n. 1, p. 25-30, 1995.

BRASIL. Ministério da Agricultura, Pecuária e Abastecimento. Instruções para a Autorização de Uso de Produtos. Instrução normativa n ${ }^{\circ} 21$, de 31 de julho de 2000. Anexo I: Regulamento técnico de identidade e qualidade de patê. Diário Oficial da União Republica Federativa do Brasil, Brasília, DF, 31 jul 2000.

BRASIL. Ministério da Agricultura, Pecuária e Abastecimento. Regulamento técnico de atribuição de aditivos, e seus limites das seguintes categorias de alimentos: categoria 8: carnes e produtos cárneos. Instrução Normativa $n^{0} 51$. Diário Oficial da República Federativa do Brasil, Brasília, DF, 04 jan 2007.

BROOKS, B.W.; RICHMOND, H.N.; ZERFA, M. Phase inversion and drop formation in agitated liquid - liquid dispersions in the presence of non-ionic surfactants. In: BINKS, B.P. Modern Aspects of Emulsion Science, The Royal Society of Chemistry: Cambridge, 1998. 
BURT, S. A.; REINDERS, R. D. Antibacterial activity of selected plant essential oils against Escherichia coli O157: H7. Letters in Applied Microbiology, Oxford, v. 36, n. 3, p. 162-167, 2003.

BURT, S. Essential oils: their antibacterial properties and potential applications in foods-a review. International Journal of Food Microbiology, Amsterdam, v. 94, n. 3, p. 223-253, 2004.

CAETANO, K. S. et al. Application of active cassava starch films incorporated with oregano essential oil and pumpkin residue extract on ground beef. Journal of Food Safety, Westport, p. e12355, 2017.

CAMPO, J. D. et al. Determination of the most bioactive phenolic compounds from rosemary against Listeria monocytogenes: influence of concentration, $\mathrm{pH}$, and $\mathrm{NaCl}$. Journal of Food Science, Hoboken, v. 68, n. 6, p. 2066-2071, 2003.

CAPEK, I. Degradation of kinetically-stable o/w emulsions. Advances in Colloid and Interface Science, Amsterdam, v. 107, n. 2, p. 125-155, 2004.

CARMO, E. S.; LIMA, E. O.; SOUZA, E. L. The potential of Origanum vulgare L. (Lamiaceae) essential oil in inhibiting the growth of some food-related Aspergillus species. Brazilian Journal of Microbiology, São Paulo, v. 39, n. 2, p. 362-367, 2008.

CARSON, C. F.; MEE, B. J.; RILEY, T. V. Mechanism of action of Melaleuca alternifolia (tea tree) oil on Staphylococcus aureus determined by time-kill, lysis, leakage, and salt tolerance assays and electron microscopy.Antimicrobial Agents and Chemotherapy, Washington, v. 46, n. 6, p. 1914-1920, 2002.

CARSON, C.F.; HAMMER, K.A. Chemistry and bioactivity of essential oils. In: THORMAR, H. Lipids and Essential Oils as Antimicrobial Agents. West Sussex: Wiley, 2011, p. 203237.

CARVAlHO, A. C. F. B. et al. Presença de microrganismos mesófilos, psicrotróficos e coliformes em diferentes amostras de produtos avícolas. Arquivos do Instituto de Biologia, São Paulo, v. 72, n. 3, p. 303-307, 2005. 
CHANG, Y.; McLANDSBOROUGH, L.; McCLEMENTS, D. J. Fabrication, stability and efficacy of dual-component antimicrobial nanoemulsions: essential oil (thyme oil) and cationic surfactant (lauric arginate). Food Chemistry, Amsterdam, v. 172, p. 298-304, 2015.

CHANG, Y.; MCLANDSBOROUGH, L.; McClEMENTS, D. J. Physical properties and antimicrobial efficacy of thyme oil nanoemulsions: influence of ripening inhibitors. Journal of Agricultural and Food Chemistry, Washington, v. 60, n. 48, p. 12056-12063, 2012.

CHOULIARA, E. et al. Combined effect of oregano essential oil and modified atmosphere packaging on shelf-life extension of fresh chicken breast meat, stored at $4 \mathrm{C}$. Food Microbiology, London, v. 24, n. 6, p. 607-617, 2007.

DAVIDSON, P. M.; PARISH, M. E. Methods for testing the efficacy of food antimicrobials. Food Technology, Chicago, 1989.

DE MORAES, N. et al. Poly-lactide-co-glycolide microparticle sizes: a rational factorial design and surface response analysis. Journal of Nanoscience and Nanotechnology, Stevenson Ranch, v. 6, n. 8, p. 2403-2407, 2006.

DELAQUIS, P. J. et al. Antimicrobial activity of individual and mixed fractions of dill, cilantro, coriander and eucalyptus essential oils. International Journal of Food Microbiology, Amsterdam, v. 74, n. 1, p. 101-109, 2002.

DELGADO-PANDO, G. et al. A healthier oil combination and konjac gel as functional ingredients in low-fat pork liver pâté. Meat Science, Amsterdam, v. 88, n. 2, p. 241-248, 2011.

DELGADO-PANDO, G. et al. Enriched n- 3 PUFA/konjac gel low-fat pork liver pâté: Lipid oxidation, microbiological properties and biogenic amine formation during chilling storage. Meat Science, Amsterdam, v. 92, n. 4, p. 762-767, 2012.

DONSİ, F. et al. Nanoencapsulation of essential oils to enhance their antimicrobial activity in foods. LWT-Food Science and Technology, London, v. 44, n. 9, p. 1908-1914, 2011.

DONSİ, F.; FERRARI, G. Essential oil nanoemulsions as antimicrobial agents in food. Journal of Biotechnology, Amsterdam, v. 233, p. 106-120, 2016. 
DOOLAEGE, E. H. A. et al. Effect of rosemary extract dose on lipid oxidation, colour stability and antioxidant concentrations, in reduced nitrite liver pâtés. Meat Science, Amsterdam, v. 90, n. 4, p. 925-931, 2012.

DORMAN, H. J. D.; DEANS, S. G. Antimicrobial agents from plants: antibacterial activity of plant volatile oils. Journal of Applied Microbiology, Oxford, v. 88, n. 2, p. 308-316, 2000.

DUTCOSKY, S. D. Análise Sensorial de Alimentos. Curitiba: Ed. Universitária Champagnat, 2011 .

EE, S. L. et al. Droplet size and stability of nano-emulsions produced by the temperature phase inversion method. Chemical Engineering Journal, Amsterdam, v. 140, n. 1, p. 626-631, 2008.

ESTÉVEZ, M. et al. Fluorescence spectroscopy as a novel approach for the assessment of myofibrillar protein oxidation in oil-in-water emulsions. Meat Science, Amsterdam, v. 80, n. 4, p. 1290-1296, 2008.

ESTÉVEZ, M. et al. Sage and rosemary essential oils versus BHT for the inhibition of lipid oxidative reactions in liver pâté. LWT-Food Science and Technology, London, v. 40, n. 1, p. $58-65,2007$.

ESTÉVEZ, M.; CAVA, R. Effectiveness of rosemary essential oil as an inhibitor of lipid and protein oxidation: Contradictory effects in different types of frankfurters. Meat Science, Amsterdam, v. 72, n. 2, p. 348-355, 2006.

ESTÉVEZ, M.; CAVA, R. Lipid and protein oxidation, release of iron from heme molecule and colour deterioration during refrigerated storage of liver pâté. Meat Science, Amsterdam, v. 68, n. 4 , p. 551-558, 2004.

ESTÉVEZ, M.; VENTANAS, S.; CAVA, R. Effect of natural and synthetic antioxidants on protein oxidation and colour and texture changes in refrigerated stored porcine liver pâté. Meat Science, Amsterdam, v. 74, n. 2, p. 396-403, 2006.

ESTÉVEZ, M.; VENTANAS, S.; CAVA, R. Protein Oxidation in Frankfurters with Increasing Levels of Added Rosemary Essential Oil: Effect on Color and Texture Deterioration. Journal of Food Science, Hoboken, v. 70, n. 7, p. C427-C432, 2005. 
FARIA, E. V; YOTSUYANAGI, K. Técnicas de Análise Sensorial. Campinas: ITAL/LAFISE, 2002.

FASSEAS, M. K. et al. Antioxidant activity in meat treated with oregano and sage essential oils. Food Chemistry, Amsterdam, v. 106, n. 3, p. 1188-1194, 2008.

FATHI, M.; MOZAFARI, M. R.; MOHEBBI, M. Nanoencapsulation of food ingredients using lipid based delivery systems. Trends in food science $\&$ technology, Cambridge, v. 23, n. 1, p. 13-27, 2012.

FERNANDES, R. P. P. et al. Stability of lamb loin stored under refrigeration and packed in different modified atmosphere packaging systems. Meat Science, Amsterdam, v. 96, n. 1, p. $554-561,2014$

FERNANDEZ, P. et al. Nano-emulsion formation by emulsion phase inversion. Colloids and Surfaces A: Physicochemical and Engineering Aspects, Amsterdam, v. 251, n. 1, p. 53-58, 2004.

FRANCIS, F. J.; CLYDESDALE, F. M. Food colorimetry: theory and applications. Westport, CT: The AVI Publishing Co., 1975.

FRANCO, R. M.; MANTILHA, S. P. S.; LEITE, A. M. O. Enumeração de Escherichia coli em carne bovina e de aves através de metodologia miniaturizada utilizando-se "eppendorf” e caldo fluorogênico. Revista Portuguesa de Ciências Veterinárias, Lisboa, v. 103, n. 567-568, p. 201-207, 2008.

GARDNER, H. W. Lipid hydroperoxide reactivity with proteins and amino acids: a review. Journal of Agricultural and Food Chemistry, Washington, v. 27, n. 2, p. 220-229, 1979.

GAYSINSKY, S. (2007). Emulsions and microemulsions as antimicrobial delivery systems. Tese (Doutorado) - Departament of Food Science, University of Massachussets at Amherst, 2007.

GHOSH, V.; MUKHERJEE, A.; CHANDRASEKARAN, N. Eugenol-loaded antimicrobial nanoemulsion preserves fruit juice against, microbial spoilage. Colloids and Surfaces B: Biointerfaces, Amsterdam, v. 114, p. 392-397, 2014. 
GILL, A. O. et al. Evaluation of antilisterial action of cilantro oil on vacuum packed ham. International Journal of Food Microbiology, Amsterdam, v. 73, n. 1, p. 83-92, 2002.

GOMES, G. V. L. et al. Physico-chemical stability and in vitro digestibility of beta-caroteneloaded lipid nanoparticles of cupuacu butter (Theobroma grandiflorum) produced by the phase inversion temperature (PIT) method. Journal of Food Engineering, London, v. 192, p. 93$102,2017$.

GONÇALVES, N. D. et al. Encapsulated thyme (Thymus vulgaris) essential oil used as a natural preservative in bakery product. Food Research International, Essex, v. 96, p. 154$160,2017$.

GRÜN, I. etal. Reducing oxidation of meat. Food Technology, Chicago, v. 1, p. 36-43, 2006.

GUTIERREZ, J.; BARRY-RYAN, C.; BOURKE, P. The antimicrobial efficacy of plant essential oil combinations and interactions with food ingredients. International Journal of Food Microbiology, Amsterdam, v. 124, n. 1, p. 91-97, 2008.

HA, T. V. A. et al. Antioxidant activity and bioaccessibility of size-different nanoemulsions for lycopene-enriched tomato extract. Food Chemistry, Amsterdam, v. 178, p. 115-121, 2015.

HAMMER, K.A.; CARSON, C.F. Antibacterial and antifungal activities in essential oils. In: THORMAR, H. Lipids and essential oils as antimicrobial agents. West Sussex: Wiley, 2011, p. 255-305.

HAMOUDA, T. et al. A novel surfactant nanoemulsion with a unique non-irritant topical antimicrobial activity against bacteria, enveloped viruses and fungi. Microbiological Research, Jena, v. 156, n. 1, p. 1-7, 2001.

HAMOUDA, T.; BAKER, J. R. Antimicrobial mechanism of action of surfactant lipid preparations in enteric Gram-negative bacilli. Journal of Applied Microbiology, Oxford, v. 89, n. 3, p. 397-403, 2000.

HASHEMI, S. M. B. et al. Basil-seed gum containing Origanum vulgare subsp. viride essential oil as edible coating for fresh cut apricots. Postharvest Biology and Technology, Amsterdam, v. 125, p. 26-34, 2017. 
HERNÁNDEZ, H. et al. The effect of oregano essential oil on microbial load and sensory attributes of dried meat. Journal of the Science of Food and Agriculture, Oxford, v. 97, n. 1, p. 82-87, 2017.

HULANKOVA, R.; BORILOVA, G.; STEINHAUSEROVA, I. Combined antimicrobial effect of oregano essential oil and caprylic acid in minced beef. Meat Science, Amsterdam, v. 95, n. 2, p. 190-194, 2013.

IZQUIERDO, P. et al. Phase behavior and nano-emulsion formation by the phase inversion temperature method. Langmuir, Washington, v. 20, n. 16, p. 6594-6598, 2004.

IZUMIMOTO, M.; ONYANGO, C. A.; DARMADJI, P. Comparison of distillation and extraction methods in TBARS determanation of cured meat. Scientific Reports of the Faculty of Agriculture Okayama University, Okayama, v. 86, n. 1, p. 55-59, 1997.

JAHANZAD, F. et al. Catastrophic phase inversion via formation of multiple emulsions: A prerequisite for formation of fine emulsions. Chemical Engineering Research and Design, London, v. 87, n. 4, 492-498, 2009.

JAKOBSEN, M.; BERTELSEN, G. Colour stability and lipid oxidation of fresh beef. Development of a response surface model for predicting the effects of temperature, storage time, and modified atmosphere composition. Meat Science, Amsterdam, v. 54, n. 1, p. 49-57, 2000.

JARDINE, D. et al. Liquid chromatography- mass spectrometry (LC-MS) investigation of the thiobarbituric acid reactive substances (TBARS) reaction. Journal of Agricultural and Food Chemistry, Washington, v. 50, n. 6, p. 1720-1724, 2002.

JAY, J. M. Microbiologia de Alimentos. Porto Alegre: Editora Artmed, 2005.

JEMAA, M. B. et al. Quality preservation of deliberately contaminated milk using thyme free and nanoemulsified essential oils. Food Chemistry, Amsterdam, v. 217, p. 726-734, 2017.

JO, Y. J. et al. Physical and antimicrobial properties of trans-cinnamaldehyde nanoemulsions in water melon juice. LWT-Food Science and Technology, London, v. 60, n. 1, p. 444-451, 2015. 
JONGBERG, S. et al. Effect of green tea or rosemary extract on protein oxidation in Bologna type sausages prepared from oxidatively stressed pork. Meat Science, Amsterdam, v. 93, n. 3, p. 538-546, 2013.

JOUNG, H. J. et al. Development of Food-Grade Curcumin Nanoemulsion and its Potential Application to Food Beverage System: Antioxidant Property and In Vitro Digestion. Journal of Food Science, Hoboken, v. 81, n. 3, N745-N753, 2016.

KABALNOV, A. Ostwald ripening and related phenomena. Journal of Dispersion Science and Technology, New York, v. 22, n. 1, p. 1-12, 2001.

KARABAGIAS, I.; BADEKA, A.; KONTOMINAS, M. G. Shelf life extension of lamb meat using thyme or oregano essential oils and modified atmosphere packaging. Meat Science, Amsterdam, v. 88, n. 1, p. 109-116, 2011.

KHANJARI, A.; KARABAGIAS, I. K.; KONTOMINAS, M. G. Combined effect of N, Ocarboxymethyl chitosan and oregano essential oil to extend shelf life and control Listeria monocytogenes in raw chicken meat fillets. LWT-Food Science and Technology, London, v. 53, n. 1, p. 94-99, 2013.

KOLEVA, I. I. et al. Screening of plant extracts for antioxidant activity: a comparative study on three testing methods. Phytochemical Analysis, Chichester, v. 13, n. 1, p. 8-17, 2002.

KOMAIKO, J. S.; MCCLEMENTS, D. J. Formation of food-grade nanoemulsions using lowenergy preparation methods: a review of available methods. Comprehensive Reviews in Food Science and Food Safety, Chicago, v. 15, n. 2, p. 331-352, 2016.

KULISIC, T. et al. Use of different methods for testing antioxidative activity of oregano essential oil. Food Chemistry, Amsterdam, v. 85, n. 4, p. 633-640, 2004.

LABUZA, T. P.; SCHMIDL, M. K. Use of sensory data in the shelf life testing of foods: principles and graphical methods for evaluation. Cereal Foods World, San Diego, v. 33, p. 193-206, 1988. 
LAMBERT, R. J. W. et al. A study of the minimum inhibitory concentration and mode of action of oregano essential oil, thymol and carvacrol. Journal of Applied Microbiology, Oxford, v. 91, n. 3, p. 453-462, 2001.

LANE, K. E. et al. Sensory evaluation of a yogurt drink containing an omega-3 nanoemulsion with enhanced bioavailability. Proceedings of the Nutrition Society, London, v. 72, n. OCE2, p. E99, 2013.

LEE, S. et al. The effects of antioxidant combinations on color and lipid oxidation in $n^{-} 3$ oil fortified ground beef patties. Meat Science, Amsterdam, v. 70, n. 4, p. 683-689, 2005.

LEUSCHNER, R. G. K.; ZAMPARINI, J. Effects of spices on growth and survival of Escherichia coli 0157 and Salmonella enterica serovar Enteritidis in broth model systems and mayonnaise. Food Control, Vurrey, v. 13, n. 6, p. 399-404, 2002.

LIANG, R. et al. Physical and antimicrobial properties of peppermint oil nanoemulsions. Journal of Agricultural and Food Chemistry, Washington, v. 60, n. 30, p. 7548-7555, 2012.

LIFSHITZ, I. M.; SLYOZOV, V. V. The kinetics of precipitation from supersaturated solid solutions. Journal of Physics and Chemistry of Solids, New York, v. 19, n. 1-2, p. 35-50, 1961.

LORENZO, J. M. et al. Effect of fat content on physical, microbial, lipid and protein changes during chill storage of foal liver pâté. Food Chemistry, Amsterdam, v. 155, p. 57-63, 2014b.

LORENZO, J. M. et al. Influence of natural extracts on the shelf life of modified atmospherepackaged pork patties. Meat Science, Amsterdam, v. 96, n. 1, p. 526-534, 2014a.

LORENZO, J. M.; GÓMES, M. Shelf life of fresh foal meat under MAP, overwrap and vacuum packaging conditions. Meat Science, Amsterdam, p. 92, n. 4, p. 610-618, 2012.

LORENZO, J. M.; PATEIRO, M. Influence of fat content on physico-chemical and oxidative stability of foal liver pâté. Meat Science, Amsterdam, v. 95, n. 2, p. 330-335, 2013.

MAHDI, E. S. et al. Formulation and in vitro release evaluation of newly synthesized palm kernel oil esters-based nanoemulsion delivery system for 30\% ethanolic dried extract derived 
from local Phyllanthus urinaria for skin antiaging. International Journal of Nanomedicine, Auckland, v. 6, p. 2499-2512, 2011.

MAYER, S.; WEISS, J.; MCCLEMENTS, D. J. Vitamin E-enriched nanoemulsions formed by emulsion phase inversion: factors influencing droplet size and stability. Journal of Colloid and Interface Science, Maryland Heights, v. 402, p. 122-130, 2013.

MCCLEMENTS, D. J. Edible nanoemulsions: fabrication, properties, and functional performance. Soft Matter, Cambridge, v. 7, n. 6, p. 2297-2316, 2011.

MCCLEMENTS, D. J. et al. Inhibition of Ostwald ripening in model beverage emulsions by addition of poorly water soluble triglyceride oils. Journal of Food Science, Hoboken, v. 77, n. 1, p. C33-C38, 2012.

McCLEMENTS, D. J. Nanoemulsions versus microemulsions: terminology, differences, and similarities. Soft Matter, Cambridge, v. 8, n. 6, p. 1719-1729, 2012.

McCLEMENTS, D. J.; RAO, J. Food-grade nanoemulsions: formulation, fabrication, properties, performance, biological fate, and potential toxicity. Critical Reviews in Food Science and Nutrition, Boca Raton, v. 51, n. 4, p. 285-330, 2011.

McCLEMENTS, D.J. Food Emulsions: Principles, Practices and Techniques. $2^{\mathrm{a}}$ ed. Boca Raton: CRC Press, 2004.

MECHERGUI, K. et al. Effect of harvest year on production, chemical composition and antioxidant activities of essential oil of oregano (Origanum vulgare subsp glandulosum (Desf.) Ietswaart) growing in North Africa. Industrial Crops and Products, Amsterdam, v. 90, p. 32$37,2016$.

MOGHIMI, R. et al. Investigations of the effectiveness of nanoemulsions from sage oil as antibacterial agents on some food borne pathogens. LWT-Food Science and Technology, London, v. 71, p. 69-76, $2016 \mathrm{a}$.

MOGHIMI, R. et al. Superior antibacterial activity of nanoemulsion of Thymus daenensis essential oil against E. coli. Food Chemistry, Amsterdam, v. 194, p. 410-415, 2016 b. 
MOON, J. K.; SHIBAMOTO, T. Antioxidant assays for plant and food components. Journal of Agricultural and Food Chemistry, Washington, v. 57, n. 5, p. 1655-1666, 2009.

MORAES-LOVISON, M. et al. Nanoemulsions encapsulating oregano essential oil: Production, stability, antibacterial activity and incorporation in chicken pâté. LWT-Food Science and Technology, London, v. 77, p. 233-240, 2017.

MORRISSEY, P. A. et al. Lipid stability in meat and meat products. Meat Science, Amsterdam, v. 49, p. S73-S86, 1998.

MOURE, A. et al. Natural antioxidants from residual sources. Food Chemistry, Amsterdam, v. 72 , n. 2, p. 145-171, 2001.

MOUREY, A.; CANILLAC, N. Anti-Listeria monocytogenes activity of essential oils components of conifers.Food Control, Vurrey, v. 13, n. 4, p. 289-292, 2002.

NAVEENA, B. M. et al. Improvement of shelf-life of buffalo meat using lactic acid, clove oil and vitamin C during retail display. Meat Science, Amsterdam, v. 74, n. 2, p. 409-415, 2006.

NEGI, P. S. Plant extracts for the control of bacterial growth: Efficacy, stability and safety issues for food application. International Journal of Food Microbiology, Amsterdam, v. 156, n. 1, p. $7-17,2012$.

NIXDORFF, K.; GMEINER, J.; MARTIN, H. H. Interaction of lipopolysaccharide with detergents and its possible role in the detergent resistance of the outer membrane of gramnegative bacteria. Biochimica et Biophysica Acta (BBA) - Biomembranes, Amsterdam, v. 510, n. 1, p. 87-98, 1978.

OLIVEIRA, A. M. et al. Manipuladores de alimentos: um fator de risco. Higiene Alimentar, São Paulo, v. 17, n. 114/115, p. 12-8, 2003.

OLIVEIRA, T. L. C.; SOARES, R. A.; PICCOLI, R. H. A Weibull model to describe antimicrobial kinetics of oregano and lemongrass essential oils against Salmonella Enteritidis in ground beef during refrigerated storage. Meat Science, Amsterdam, v. 93, n. 3, p. 645-651, 2013. 
OLIVER, C. N. et al. Aged-related changes in oxidized proteins. The Journal of Biological Chemistry, New York, v. 262, p. 5488-5491, 1987.

ORAL, N. et al. Effect of absorbent pads containing oregano essential oil on the shelf life extension of overwrap packed chicken drumsticks stored at four degrees Celsius. Poultry Science, College Station, v. 88, n. 7, p. 1459-1465, 2009.

OSTERTAG, F., WEISS, J.; McCLEMENTS, D. J. Low-energy formation of edible nanoemulsions: Factors influencing droplet size produced by emulsion phase inversion. Journal of Colloid and Interface Science, Maryland Heights, v. 388, n. 1, p. 95-102, 2012.

OTONI, C. G. et al. Edible films from methylcellulose and nanoemulsions of clove bud (Syzygium aromaticum) and oregano (Origanum vulgare) essential oils as shelf life extenders for sliced bread. Journal of Agricultural and Food Chemistry, Washington, v. 62, n. 22, p. 5214-5219, 2014.

OZOGUL, Y. et al. The combined impact of nanoemulsion based on commercial oils and vacuum packing on the fatty acid profiles of sea bass fillets. Journal of Food Processing and Preservation, Westport, 2017.

PAPARELLA, A. et al. Chitosan boosts the antimicrobial activity of Origanum vulgare essential oil in modified atmosphere packaged pork. Food Microbiology, London, v. 59, p. 23$31,2016$.

PATEIRO, M. et al. Effect of addition of green tea, chestnut and grape extract on the shelf-life of pig liver pâté. Food Chemistry, Amsterda, v. 147, p. 386-394, 2014.

PAVELKOVÁ, A. et al. The effect of vacuum packaging, EDTA, oregano and thyme oils on the microbiological quality of chicken's breast. Anaerobe, London, v. 29, p. 128-133, 2014.

PERAZZO, A., PREZIOSI, V.; GUIDO, S. Phase inversion emulsification: Current understanding and applications. Advances in Colloid and Interface Science, Amsterdam, v. 222, p. 581-599, 2015.

PEREIRA, D. Desenvolvimento de microcápsulas bioativas de coprodutos de suco e vinho da uva visando sua aplicação como antioxidante natural em patê de carne de frango. 2015. 
135 f. Dissertação (Mestrado em Tecnologia de Processos Químicos e Bioquímicos) Universidade Tecnológica Federal do Paraná, Pato Branco, 2015.

QUIROGA, P. R.; GROSSO, N. R.; NEPOTE, V. Antioxidant effect of poleo and oregano essential oil on roasted sunflower seeds. Journal of Food Science, Hoboken, v. 78, n. 12, p. S1904-S1912, 2013.

RANJBAR, M.; AZIZI, M. H. Microbial, Chemical, and Sensorial Properties of Chicken Fillets Coated by Gelatin-Carboxymethyl Cellulose Film Containing Essential Oil of Bene (Pistacia atlantica). Journal of Food Quality \& Hazards Control, Yazd, v. 4, n. 1, p. 14-19, 2017.

RAO, J.; McCLEMENTS, D. J. Stabilization of phase inversion temperature nanoemulsions by surfactant displacement. Journal of Agricultural and Food Chemistry, Washington, v. 58, n. 11, p. 7059-7066, 2010.

RHAYOUR, K. et al. The mechanism of bactericidal action of oregano and clove essential oils and of their phenolic major components on Escherichia coli and Bacillus subtilis. Journal of Essential Oil Research, Wheaton, v. 15, n. 4, p. 286-292, 2003.

RICHARDS, M. P. et al. Ability of surfactant micelles to alter the partitioning of phenolic antioxidants in oil-in-water emulsions. Journal of Agricultural and Food Chemistry, Washington, v. 50, n. 5, p. 1254-1259, 2002.

RODRÍGUEZ-CARPENA, J. G.; MORCUENDE, D.; ESTÉVEZ, M. Avocado by-products as inhibitors of color deterioration and lipid and protein oxidation in raw porcine patties subjected to chilled storage. Meat Science, Amsterdam, v. 89, n. 2, p. 166-173, 2011.

RODRIGUEZ-GARCIA, I. et al. Oregano (Lippia graveolens) essential oil added within pectin edible coatings prevents fungal decay and increases the antioxidant capacity of treated tomatoes. Journal of the Science of Food and Agriculture, Oxford, v. 96, p. 3772-3778, 2016.

RONDÓN-GONZÁLEZ, M. et al. Emulsion inversion from abnormal to normal morphology by continuous stirring without internal phase addition: effect of surfactant mixture fractionation at extreme water-oil ratio. Colloids and Surfaces A: Physicochemical and Engineering Aspects, Amsterdam, v. 288, n. 1, p. 151-157, 2006. 
ŞAHIN, F. et al. Biological activities of the essential oils and methanol extract of Origanum vulgare ssp. vulgare in the Eastern Anatolia region of Turkey. Food Control, Vurrey, v. 15, n. 7, p. 549-557, 2004.

SAJJADI, S. Nanoemulsion formation by phase inversion emulsification: on the nature of inversion. Langmuir, Washington, v. 22, n. 13, p. 5597-5603, 2006.

SALAGER, J.L. Emulsion phase inversion phenomena. In: SJÖBLOM, J. Emulsions and emulsion stability. Taylor and Francis: Boca Raton, 2006, p. 185-225.

SALVIA-TRUJILLO, L. et al. Physicochemical characterization and antimicrobial activity of food-grade emulsions and nanoemulsions incorporating essential oils. Food Hydrocolloids, Amsterdam, v. 43, p. 547-556, 2015.

SÁNCHEZ-ESCALANTE, A. et al. Antioxidant action of borage, rosemary, oregano, and ascorbic acid in beef patties packaged in modified atmosphere. Journal of Food Science, Hoboken, v. 68, n. 1, p. 339-344, 2003.

SARTORATTO, A. et al. Composition and antimicrobial activity of essential oils from aromatic plants used in Brazil. Brazilian Journal of Microbiology, São Paulo, v. 35, n. 4, p. 275-280, 2004.

SHADMAN, S. et al. Evaluation of the effect of a sunflower oil-based nanoemulsion with Zataria multiflora Boiss. essential oil on the physicochemical properties of rainbow trout (Oncorhynchus mykiss) fillets during cold storage. LWT-Food Science and Technology, London, v. 79, p. 511-517, 2017.

SHAHIDI, F.; ZHONG, Y. Lipid oxidation and improving the oxidative stability. Chemical Society Reviews, London, v. 39, n. 11, p. 4067-4079, 2010.

SHINODA, K.; SAITO, H. The effect of temperature on the phase equilibria and the types of dispersions of the ternary system composed of water, cyclohexane, and nonionic surfactant. Journal of Colloid and Interface Science, Maryland Heights, v. 26, n. 1, p. 70-74, 1968. 
SI, H. et al. Antibacterial effect of oregano essential oil alone and in combination with antibiotics against extended-spectrum $\beta$-lactamase-producing Escherichia coli. FEMS Immunology \& Medical Microbiology, Amsterdam, v. 53, n. 2, p. 190-194, 2008.

SIGMA-ALDRICH . Produces and sells a broad range of biochemicals, organic and inorganic chemicals and related products. Disponível em: < http://www.sigmaaldrich.com/brazil.html $>$. Acesso em 15 abr. 2017.

SILVA, H. D.; CERQUEIRA, M. Â.; VICENTE, A. A. Nanoemulsions for food applications: development and characterization. Food and Bioprocess Technology, New York, v. 5, n. 3, p. 854-867, 2012.

SILVA, N. Et al. Manual de Métodos de Análise Microbiológica de Alimentos e Água. $4^{\mathrm{a}}$ ed., São Paulo: Livrara Varela, 2010.

SILVA, N.; JUNQUEIRA, V. C. A.; SILVEIRA, N. S. A. 2002. Manual de Métodos de Análise Microbiológica de Alimentos. $3^{\text {a }}$ ed., São Paulo: livraria Varela, 2002.

SINGLETON, V. L.; ORTHOFER, R.; LAMUELA-RAVENTÓS, R. M. Analysis of total phenols and other oxidation substrates and antioxidants by means of folin-ciocalteu reagent. Methods in Enzymology, New York, v. 299, p. 152-178, 1999.

SOLANS, C. et al. Nano-emulsions. Current Opinion in Colloid \& Interface science, Amsterdam, v. 10, n. 3, p. 102-110, 2005.

SOLANS, C.; SOLÉ, I. Nano-emulsions: formation by low-energy methods. Current Opinion in Colloid \& Interface Science, Amsterdam, v. 17, n. 5, p. 246-254, 2012.

SOUZA, E. L. et al. Combined application of Origanum vulgare L. essential oil and acetic acid for controlling the growth of Staphylococcus aureus in foods. Brazilian Journal of Microbiology, São Paulo, v. 40, n. 2, p. 387-393, 2009.

SOUZA, E. L. et al. Influence of Origanum vulgare L. essential oil on enterotoxin production, membrane permeability and surface characteristics of Staphylococcus aureus. International Journal of Food Microbiology, Amsterdam, v. 137, n. 2, p. 308-311, 2010. 
SOW, L C. et al. Carvacrol nanoemulsion combined with acid electrolysed water to inactivate bacteria, yeast in vitro and native microflora on shredded cabbages. Food Control, Vurrey, v. 76, p. 88-95, 2017.

SPERNATH, L.; MAGDASSI, S. A new method for preparation of poly-lauryl acrylate nanoparticles from nanoemulsions obtained by the phase inversion temperature process. Polymers for Advanced Technologies, New York, v. 18, n. 9, p. 705-711, 2007.

STADTMAN, E. R.; LEVINE, R. L. Free radical-mediated oxidation of free amino acids and amino acid residues in proteins. Amino Acids, Wien, v. 25, n. 3-4, p. 207-218, 2003.

STAMENIC, M. et al. Free-radical scavenging activity and antibacterial impact of Greek oregano isolates obtained by SFE. Food Chemistry, Amsterdam, v. 165, p. 307-315, 2014.

STANOJEVIĆ, L. P. et al. Antioxidant activity of oregano essential oil (Origanum vulgare L.). Biologica Nyssana, Kopaonik, v. 7, n. 2, 2016.

SUGUMAR, S. et al. Nanoemulsion of orange oil with non ionic surfactant produced emulsion using ultrasonication technique: evaluating against food spoilage yeast. Applied Nanoscience, Berlin, v. 6, n. 1, p. 113-120, 2016.

TADROS, T. et al. Formation and stability of nano-emulsions. Advances in Colloid and Interface Science, Amsterdam, v. 108, p. 303-318, 2004.

TANABE, H.; YOSHIDA, M.; TOMITA, N. Comparison of the antioxidant activities of 22 commonly used culinary herbs and spices on the lipid oxidation of pork meat. Animal Science Journal, Hoboken, v. 73, n. 5, p. 389-393, 2002.

TANAKA, M. et al. Evidence for interpenetration of core triglycerides into surface phospholipid monolayers in lipid emulsions. Langmuir, Washington, v. 19, n. 13, p. 51925196, 2003.

TASSOU, C.; KOUTSOUMANIS, K.; NYCHAS, G. J. E. Inhibition of Salmonella enteritidis and Staphylococcus aureus in nutrient broth by mint essential oil. Food Research International, Essex, v. 33, n. 3, p. 273-280, 2000. 
TAYLOR, P. Ostwald ripening in emulsions: estimation of solution thermodynamics of the disperse phase. Advances in Colloid and Interface Science, Amsterdam, v. 106, n. 1, p. 261$285,2003$.

TERJUNG, N. et al. Influence of droplet size on the efficacy of oil-in-water emulsions loaded with phenolic antimicrobials. Food \& Function, Cambridge, v. 3, n. 3, p. 290-301, 2012.

VAARA, M. Agents that increase the permeability of the outer membrane. Microbiological reviews, Washington, v. 56, n. 3, p. 395-411, 1992.

VAN HAUTE, S. et al. Combined use of cinnamon essential oil and MAP/vacuum packaging to increase the microbial and sensorial shelf life of lean pork and salmon.Food Packaging and Shelf Life, v. 12, p. 51-58, 2017.

VAZIRIAN, M. et al. Chemical composition and antioxidant activity of Origanum vulgare subsp. vulgare essential oil from Iran. Research Journal of Pharmacognosy, Tehran v. 2, n. 1, p. 41-46, 2015.

VIUDA-MARTOS, M. et al. Citrus Co-Products as Technological Strategy to Reduce Residual Nitrite Content in Meat Products. Journal of Food Science, Hoboken, v. 74, n. 8, p. R93-R100, 2009 .

WAGNER, C. Theorie der alterung von niederschlägen durch umlösen (Ostwald-reifung). Berichte der Bunsen-Gesellschaft für Physikalische Chemie, Weinheim, v. 65, n. 7-8, p. 581-591, 1961.

WALKER, R.; DECKER, E. A.; MCCLEMENTS, D. J. Development of food-grade nanoemulsions and emulsions for delivery of omega-3 fatty acids: opportunities and obstacles in the food industry. Food \& Function, Cambridge, v. 6, n. 1, p. 41-54, 2015.

WANG, L. et al. Design and optimization of a new self-nanoemulsifying drug delivery system. Journal of Colloid and Interface Science, Maryland Heights, v. 330, n. 2, p. 443-448, 2009.

WEISS, J. et al. Nanostructured encapsulation systems: food antimicrobials. In: BARBOSACÁNOVAS, G.V. et al. IUFoST World Congress Book: Global Issues in Food Science and Technology. Elsevier Inc: Amsterdam, 2009. 
WEISS, J.; LOEFFLER, M.; TERJUNG, N. The antimicrobial paradox: why preservatives lose activity in foods. Current Opinion in Food Science, Amsterdam, v. 4, p. 69-75, 2015.

WOOSTER, T. J.; GOLDING, M.; SANGUANSRI, P. Impact of oil type on nanoemulsion formation and Ostwald ripening stability. Langmuir, Washington, v. 24, n. 22, p. 12758-12765, 2008.

XUE, J.; DAVIDSON, P. M.; ZHONG, Q. Antimicrobial activity of thyme oil conanoemulsified with sodium caseinate and lecithin. International Journal of Food Microbiology, Amsterdam, v. 210, p. 1-8, 2015.

ZARRINGHALAMI, S.; SAHARI, M. A.; HAMIDI-ESFEHANI, Z. Partial replacement of nitrite by annatto as a colour additive in sausage. Meat Science, Amsterdam, v. 81, n. 1, p. 281284, 2009.

ZHANG, Z. et al. Effects of nisin on the antimicrobial activity of D-limonene and its nanoemulsion. Food Chemistry, Amsterdam, v. 150, p. 307-312, 2014.

ZIANI, K. et al. Influence of surfactant charge on antimicrobial efficacy of surfactant-stabilized thyme oil nanoemulsions. Journal of Agricultural and Food Chemistry, Washington, v. 59, n. 11, p. $6247-6255,2011$. 


\section{APÊNDICE A - Termo de consentimento livre e esclarecido}

Termo de consentimento livre e esclarecido

Consentimento formal de participação no projeto de pesquisa: "Avaliação sensorial de patê de frango com adição de óleo essencial de orégano livre e nanoemulsionado".

Nome:

Endereço:

Cidade:

CEP:

Fone:

Justificativa: O óleo essencial de orégano, por apresentar propriedades antimicrobianas e antioxidantes, é uma alternativa aos conservantes e aditivos sintéticos empregados na produção de produtos cárneos, como por exemplo, o nitrito de sódio e o BHT. Entretanto, a utilização deste óleo puro em alimentos pode alterar as propriedades sensoriais do alimento, e desta forma, a microencapsulação destes compostos, na forma de nanoemulsão, se torna uma maneira de contornar tal problema.

Objetivos do projeto: Avaliar os parâmetros de cor, sabor, odor e aceitação global de patê de frango elaborado com adição de óleo essencial de orégano nanoencapsulado.

Procedimentos: A análise onde seres humanos avaliam diversos atributos de qualidade de alimentos é chamada de ANÁLISE SENSORIAL. Os procedimentos para execução da análise sensorial nesta pesquisa serão os seguintes:

- Serão testadas formulações de patê de frango com diferentes formulações de nanoemulsões encapsulando óleo essencial de orégano e com adição de óleo essencial de orégano puro.

- O provador deverá avaliar os atributos de cor, odor e sabor das amostras e responder às perguntas solicitadas na Ficha de Avaliação.

- A duração do teste para cada pessoa será de aproximadamente 10 minutos.

. Outras informações:

- Caso haja algum desconforto ao provar as amostras, devido ao odor e sabor forte e cacracterístico do óleo essencial de orégano, o provador poderá parar a análise, tomar água e se recusar a continuar com a avaliação sensorial a qualquer momento, sem penalização alguma e sem prejuízo ao seu cuidado.

- Os provadores não terão qualquer tipo de despesas em decorrência da participação na pesquisa. - Há possibilidade de risco de contaminação microbiológica do produto oferecido ao provador, por isso, o produto será embalado em embalagens estéreis, posteriormente será submetido à pasteurização $\left(80^{\circ} \mathrm{C}\right.$ por 30 minutos $)$ e armazenamento sob refrigeração $\left(7^{\circ}-10^{\circ} \mathrm{C}\right)$ até o momento da realização das análises. Além disso, serão realizadas análises microbiológicas para assegurar a qualidade do produto de bem estar dos provadores. Todos os ingredientes utilizados na produção são inteiramente seguros e serão de boa qualidade e procedência e o processo de fabricação será realizado de acordo com as normas de Boas Práticas de Fabricação.

- O provador que apresentar algum risco de reação alérgica ao óleo essencial de orégano ou a qualquer outro componente presente na formulação do patê, poderá se recusar a fazer a análise sensorial.

- Caso ocorra alguma reação alérgica pelo consumo do produto ou algum risco à saúde do provador, há previsão de indenização em decorrência da- participação neste projeto.

- Os testes para avaliação sensorial do patê de frango, nos quais os provadores experimentarão os produtos desenvolvidos serão acompanhados pela aluna proponente (Marília Moraes Lovison).

- Quaisquer outros esclarecimentos poderão ser solicitados antes, durante e após a pesquisa.

$\mathrm{Eu}$,

$\mathrm{RG}$

$\mathrm{CPF}$

, abaixo assinado, concordo em participar do estudo "Avaliação sensorial de patê de

frango com adição de óleo essencial de orégano livre e nanoemulsionado". Tenho pleno conhecimento da justificativa, objetivos, benefícios esperados e dos procedimentos a serem executados, bem como da possibilidade de receber esclarecimentos sempre que considerar necessário. Será mantido sigilo quanto à identificação de minha pessoa e zelo a minha privacidade. Ao mesmo tempo assumo o compromisso de seguir as recomendações estabelecidas pelos pesquisadores.Eu li e entendi todas as informações contidas neste documento.

Aluna responsável: Marília Moraes Lovison (Engenheira de Alimentos) Contato: marilia.moraes@usp.br Pirassununga, de de

Assinatura: 


\section{APÊNDICE B - Ficha de Avaliação do consumidor}

Ficha de Avaliação

Nome:
1) Faixa etária
2) Sexo
3) Ocupação na faculdade
( ) menos de 25 anos
( ) Masculino
( ) aluno de graduação
( ) de 25 a 35 anos
( ) Feminino
( ) aluno de pós- graduação
( ) de 36 a 50
( ) professor
( ) funcionário
( ) mais de 50

4) Qual é o grau de instrução do chefe da família? Considere como chefe da família a pessoa que contribui com a maior parte da renda do domicílio.

( ) De analfabeto a fundamental 1 (primário) incompleto

( ) De fundamental 1 (primário) completo a fundamental 2 (ginásio) incompleto

( ) De fundamental 2 (ginásio) completo e médio (colegial) incompleto

( ) De médio (colegial) completo a superior incompleto

( ) Superior completo

5) Qual sua renda familiar (em salários mínimos)

( ) de 1 a 3 salários mínimos ( $\mathrm{R} \$ 880,00$ a $\mathrm{R} \$ 2.640,00)$

( ) de 3 a 6 salários mínimos ( $\mathrm{R} \$ 2.640,00$ a $\mathrm{R} \$ 5.280,00)$

( ) de 6 a 10 salários mínimos $(\mathrm{R} \$ 5.280,00$ a $\mathrm{R} \$ 8.800,00)$

( ) mais de 10 salários mínimos (acima de $\mathrm{R} \$ 8.800,00$ )

\section{Frequência de consumo}

1) Com que frequência, em média, você consome patê:

2) Indique o (s) lugar (es) onde você

( ) Sempre (uma vez por semana ou mais) mais costuma consumir patê:

( ) Frequentemente (de 2 a 3 vezes por mês)

( ) em casa

( ) Moderadamente (1 vez por mês)

( ) em bares/ restaurantes

( ) Algumas vezes (menos que 1 vez por mês)

( ) em festas ou reuniões sociais

( ) Raramente (somente em ocasiões especiais) 


\section{APÊNDICE C - Ficha de avaliação sensorial do patê de frango: teste de diferença do controle}

NOME:

DATA:

FICHA:

IDADE:

Você está recebendo uma amostra controle e quatro amostras codificadas de patê de frango. Por favor, prove a amostra controle e em seguida prove cada uma das amostras codificadas e avalie, utilizando a escala abaixo, o quanto cada amostra difere, em termos globais (odor, cor e sabor), da amostra controle.

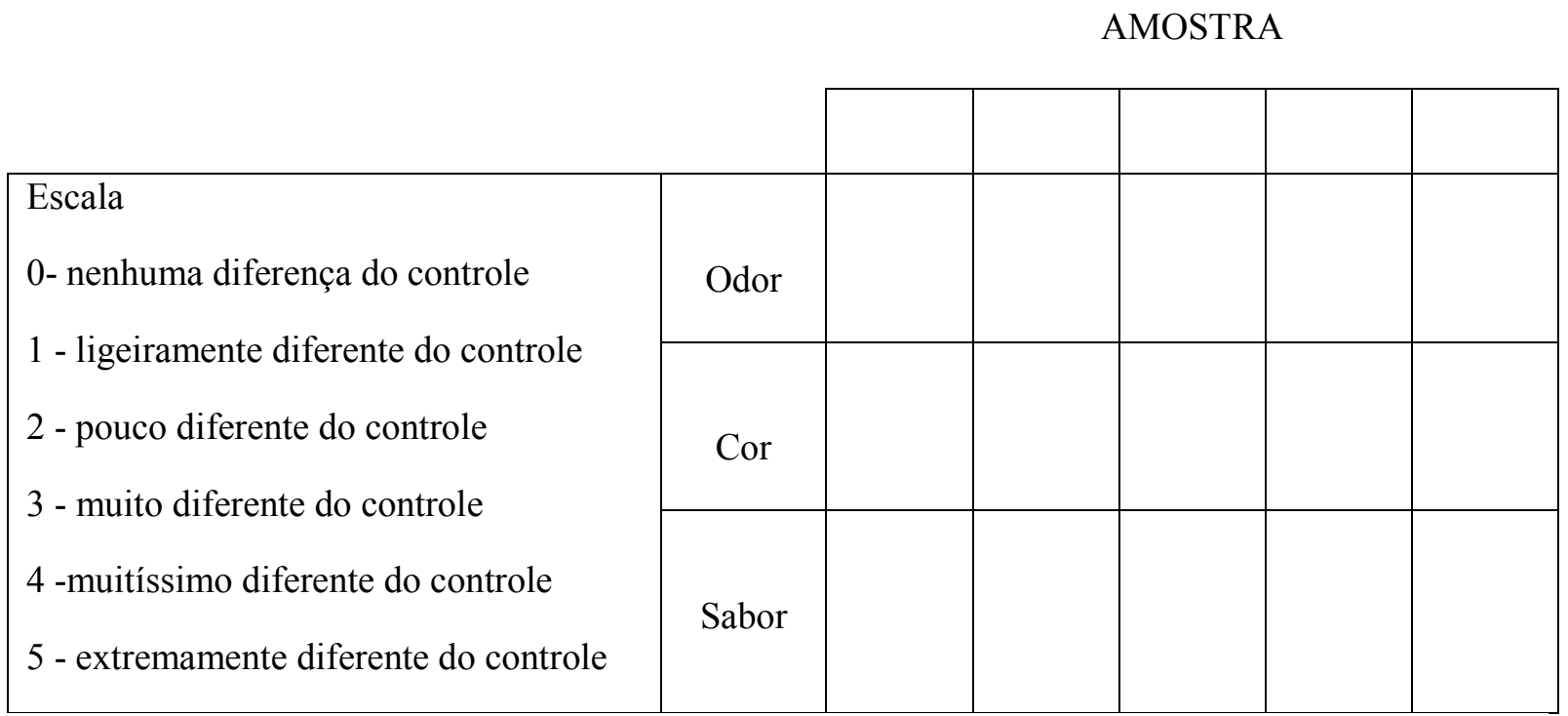

Comentários: 
APÊNDICE D - Ficha de avaliação sensorial do patê de frango: teste de aceitação (análise de odor e cor para correlacionar a aceitação com a oxidação do produto)

NOME:

DATA:

FICHA:

Você está recebendo CINCO amostras de patê de frango. Por favor, avalie o produto da esquerda para direita observando apenas o odor e a cor (SEM PROVAR), e marque de acordo com a escala o quanto você gostou ou desgostou das seguintes características:

AMOSTRA

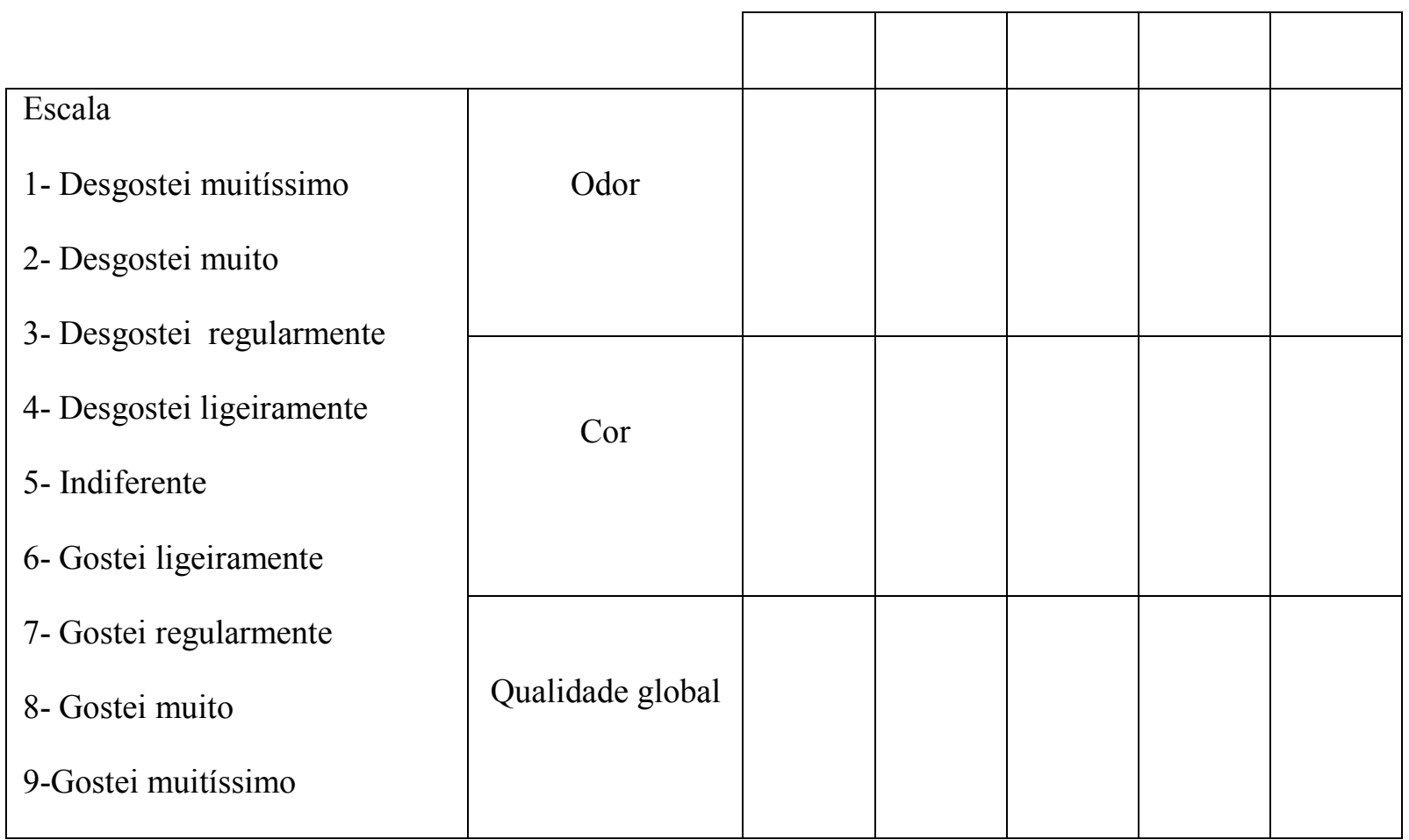

Comentários: 
APÊNDICE E - Ficha de avaliação sensorial do patê de frango: teste de aceitação e intenção de compra.

NOME:

DATA:

FICHA:

IDADE:

Você está recebendo CINCO amostras de patê de frango. Por favor, avalie o produto da esquerda para direita em relação a cor, odor e sabor, e marque de acordo com a escala o quanto você gostou ou desgostou das seguintes características:

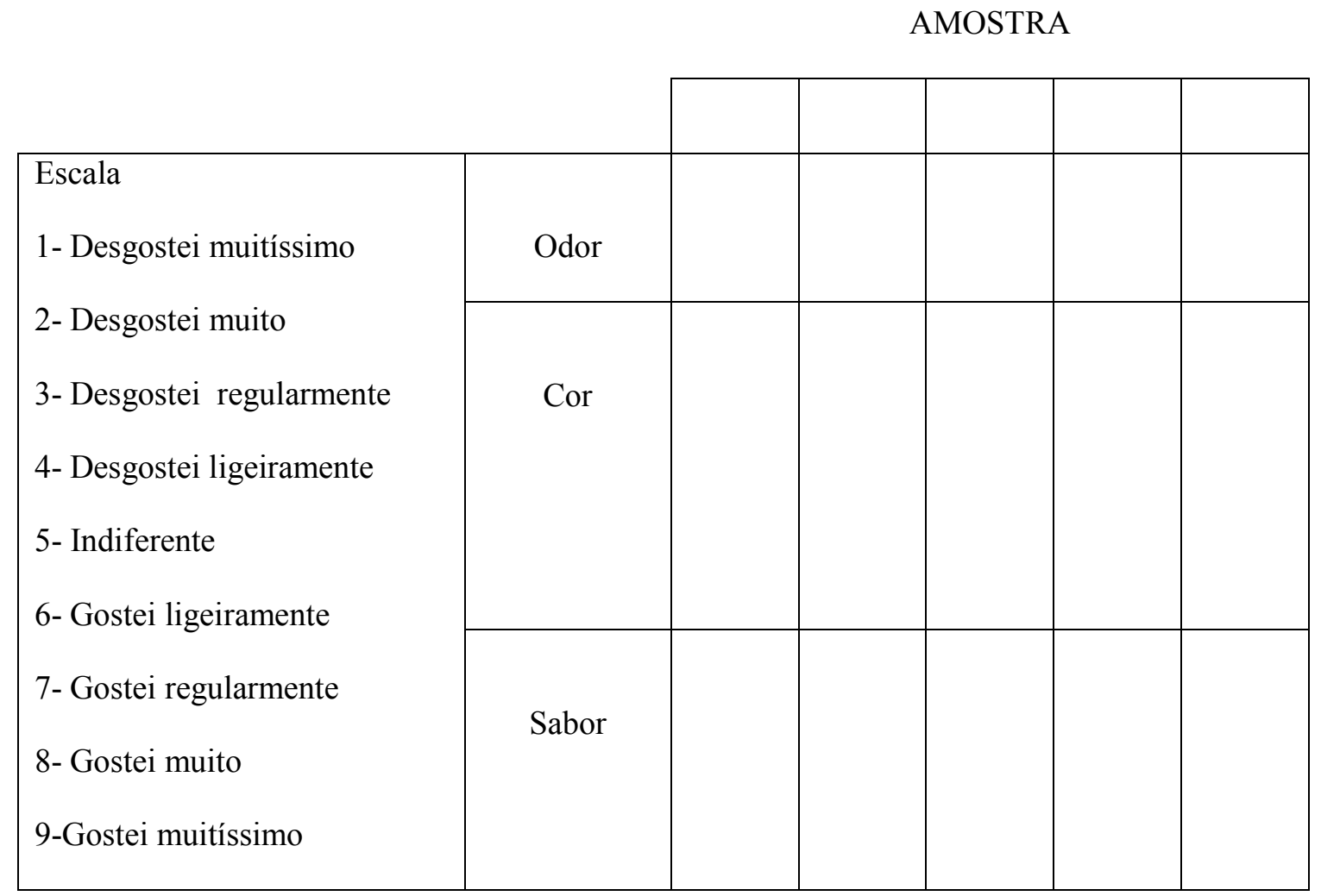

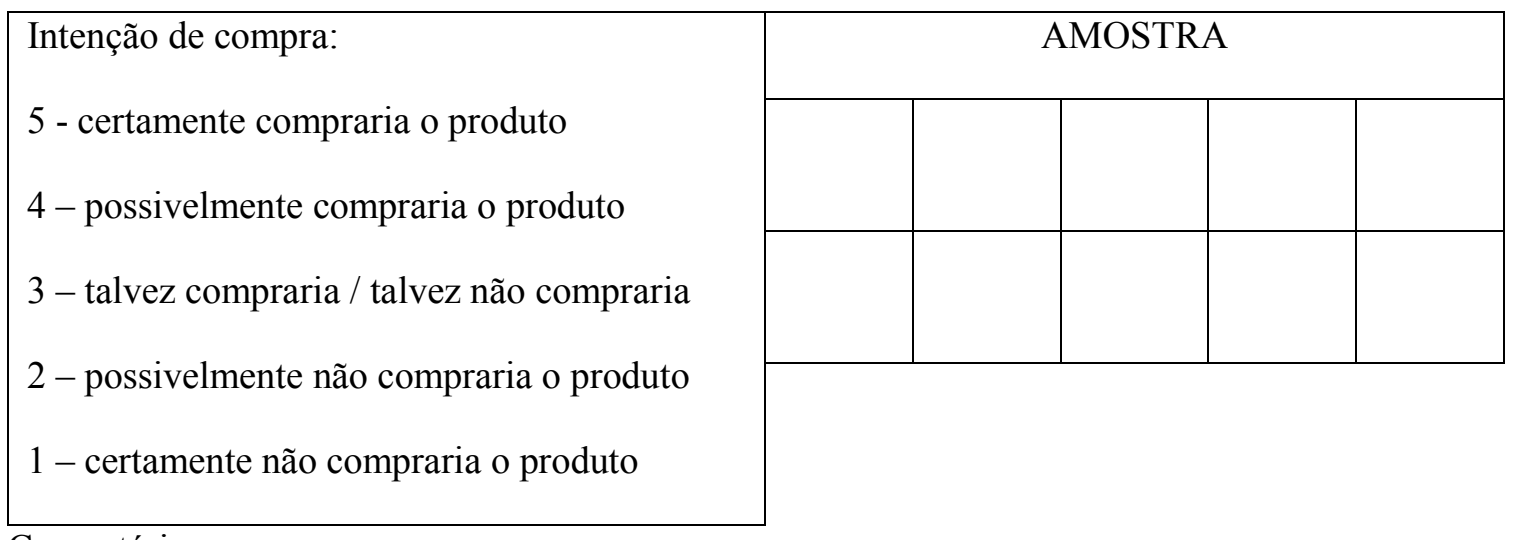

Comentários: 